\begin{abstract}
UNIVERSIDADE DE SÃO PAULO
FACULDADE DE FILOSOFIA, LETRAS E CIÊNCIAS HUMANAS DEPARTAMENTO DE LETRAS CLÁSSICAS E VERNÁCULAS PROGRAMA DE PÓS-GRADUAÇÃO EM ESTUDOS COMPARADOS DE LITERATURAS DE LÍNGUA PORTUGUESA
\end{abstract}

SANDRA REGINA KUKA MUTARELLI

O querer, o sentir e o pensar de Rudolf Steiner na literatura para crianças e jovens: os atos da vontade

VERSÃO CORRIGIDA 


\author{
UNIVERSIDADE DE SÃO PAULO \\ FACULDADE DE FILOSOFIA, LETRAS E CIÊNCIAS HUMANAS \\ DEPARTAMENTO DE LETRAS CLÁSSICAS E VERNÁCULAS \\ PROGRAMA DE PÓS-GRADUAÇÃO EM ESTUDOS COMPARADOS DE \\ LITERATURAS DE LÍNGUA PORTUGUESA
}

O querer, o sentir e o pensar de Rudolf Steiner na literatura para crianças e jovens: os atos da vontade

Sandra Regina Kuka Mutarelli

\begin{abstract}
Tese apresentada ao Programa de PósGraduação em Estudos Comparados de Literaturas de Língua Portuguesa, Departamento de Letras Clássicas e Vernáculas da Faculdade de Filosofia, Letras e Ciências Humanas da Universidade de São Paulo, para obtenção do título de Doutor em Letras.

Orientadora: Profa. Dra. Maria dos Prazeres Santos Mendes.
\end{abstract}

VERSÃO CORRIGIDA

São Paulo

2014 
Autorizo a reprodução e divulgação total ou parcial deste trabalho, por qualquer meio convencional ou eletrônico, para fins de estudo e pesquisa, desde que citada a fonte.

MUTARELLI, Sandra Regina Kuka

O querer, o sentir e o pensar de Rudolf Steiner na literatura para crianças e jovens: os atos da vontade / Sandra Regina Kuka Mutarelli; orientadora Maria dos Prazeres Santos Mendes. - São Paulo, 2014. $301 \mathrm{f}$.

Tese (Doutorado) - Faculdade de Filosofia, Letras e Ciências Humanas da Universidade de São Paulo. Departamento de Letras Clássicas e Vernáculas.

Área de Estudos Comparados de Literaturas de Língua Portuguesa.

1. Literatura Infantil. 2. Leitura. 3. Sentir e pensar. 4. Recepção da leitura. 5. Experiência estética. 6. Rudolf Steiner. 7. Os Atos da Vontade. 


\title{
O QUERER, O SENTIR E O PENSAR DE RUDOLF STEINER NA LITERATURA PARA CRIANÇAS E JOVENS: OS ATOS DA VONTADE
}

\begin{abstract}
Tese de Doutorado apresentada ao Departamento de Letras Clássicas e Vernáculas, Área de Estudos Comparados em Literaturas de Língua Portuguesa, da Faculdade de Filosofia, Letras e Ciências Humanas da Universidade de São Paulo, para obtenção do título de Doutor em Letras.
\end{abstract}

Aprovada em: 04 de dezembro de 2014

\section{BANCA EXAMINADORA}

Profa. Dra. Maria dos Prazeres Santos Mendes

Instituição: Universidade de São Paulo - USP

Julgamento:

Assinatura:

Profa. Dra. Idméa Semeghini Prospero Machado Siqueira

Instituição: Universidade de São Paulo - USP

Julgamento: Assinatura:

Profa. Dra. Maria Zilda da Cunha

Instituição: Universidade de São Paulo - USP

Julgamento: Assinatura:

Profa. Dra. Bernadete Lenza

Instituição: Universidade Paulista - UNIP

Julgamento:

Assinatura:

Prof. Dr. José Nicolau Gregorin Filho

Instituição: Universidade de São Paulo - USP

Julgamento:

Assinatura: 
À minha querida e amada mãe, Sandra, por seus ensinamentos, seu amor incondicional, sua força, determinação, vivacidade e vontade de viver. 


\section{AGRADECIMENTOS}

Meu agradecimento especial à minha orientadora, Profạ. Drạ. Maria dos Prazeres Santos Mendes, carinhosamente chamada de Prá, pelo profissionalismo, dedicação, paciência, encorajamento e carinho.

Ao Programa de Pós-Graduação em Estudos Comparados de Literaturas de Língua Portuguesa, da Faculdade de Filosofia, Letras e Ciências Humanas da Universidade de São Paulo, pela oportunidade de realização desta pesquisa.

Ao Prof. Dr. José Nicolau Gregorin Filho, pelo dinamismo e magia de suas aulas e pela condução dos meus primeiros passos nesta área.

À Prof $\stackrel{a}{a}$. Dra . Maria Zilda da Cunha, por todos os nossos encontros desde que iniciei este percurso, por suas palavras, carinho, incentivo e por suas valiosas observações no Exame de Qualificação.

À Prof ${ }^{a}$. Drâ. Idméa Semeghini-Siqueira, pela contribuição valiosa no Exame de Qualificação, pelas entrevistas realizadas com seus sobrinhos formados pela Pedagogia Waldorf, que deram uma nova direção a esta tese.

À Profa ${ }^{a}$. Drª . Maria José Palo e ao aluno Ricardo lannace, por suas considerações durante a apresentação parcial desta pesquisa no XIII Encontro de Estudos Comparados.

À Prof $\stackrel{\text { a }}{\text {. Dr }}$. Lilian Al-Chueyr Pereira Martins, minha orientadora do Mestrado em História da Ciência, na PUC, primeira e eterna mestra em meu percurso como pesquisadora.

Ao Prof. Dr. Paulo José Carvalho da Silva, que durante a co-orientação do Mestrado, sugeriu que eu guardasse uma parte do texto que não poderia ser usado naquele momento. Disse-me ter certeza que eu a usaria no futuro e, hoje, é parte do capítulo dois desta tese. 
À Prof ${ }^{\text {a }}$. Dr ${ }^{\mathrm{a}}$. Ana Maria Haddad Baptista, por suas palavras durante o Exame de Qualificação e na banca de Defesa do Mestrado, por ter me convencido de que eu tinha muito a dizer e que o fazia de maneira agradável e por ter dito que eu apresentei a ela o Goethe da Botânica.

À Carolina Casquett da Mata Santana, pela disposição e ajuda para contatar os ex-alunos Waldorf que participaram da pesquisa de campo.

À Coordenadora Andréa Marotti por nossas conversas que conduziram minha vontade de levar ao adulto as concepções de Steiner.

Ao amigo Meireles, pelo carinho, paciência e pela revisão do capítulo quatro desta tese.

Às meninas da coordenação (Claudinha, Fernanda, Mara, Priscila e Sandra), por toda a ajuda nas atividades do dia-a-dia e por terem aceitado participar do préteste da pesquisa de campo.

Aos colegas e amigos da UNIP (Bernadete Lenza, Cláudia Palladino, Ester Camastra, Flávio Martin, Hellen Coelho, Ivy Judensneider, Ligia Menna, Linduarte Vieira da Silva, Maria Zita Cecchini, Marisa Paixão, Najla Mahmoud Kamel, Sidney de Campos, Tiago Ramos, Valéria Viaro e Zulimar Boro), pelas palavras de incentivo nos momentos mais difíceis, empréstimo de livros, sugestões de leitura e dicas valiosas.

Aos amigos Emilio Bocchino, lara Yamamoto e Isabel Italiano, pelo carinho, apoio, cumplicidade e incentivo.

Aos meus irmãos Lourenço e Luiz Fernando, à minha cunhada Lucimar e ao meu sobrinho Francisco, por me amarem e acreditarem sempre em mim.

Aos meus enteados Felipe, Tathiana, Talitha, Tamara, à mãe deles (Rute da Cunha), aos meus genros Caio e George, pelo interesse constante, palavras de encorajamento e torcida. 
Ao Miguel, meu netinho do coração, ouvinte atento de todas as estórias que tenho para contar, que me fez decorar o poema Pobre Vovô! com seus "de novo".

Ao Galeno e à Sophie, meus dois anjinhos da raça Shih Tzu, pelos passeios relaxantes, pelas lambidinhas de encorajamento e por estarem sempre ao meu lado.

Emoldurando esta sequência, sendo o primeiro em meu coração, ao meu marido, Wanderley, por permitir que eu voe cada vez mais alto, por seu carinho, amor, paciência e cumplicidade. 


\section{RESUMO}

MUTARELLI, Sandra R. Kuka. O querer, o sentir e o pensar de Rudolf Steiner na literatura para crianças e jovens: os atos da vontade. $301 \mathrm{p}$. Tese (Doutorado). Faculdade de Filosofia, Letras e Ciências Humanas, Universidade de São Paulo, São Paulo, 2014.

Rudolf Steiner (1861-1925) foi um filósofo, jornalista e educador. Atualmente seu nome está associado ao movimento Camphill de educação curativa, sua arquitetura, vários estudos sobre religião, à agricultura biodinâmica, à medicina antroposófica e à pedagogia Waldorf. O objetivo principal desta pesquisa é investigar a contribuição e validade das concepções sobre o querer, o sentir e o pensar de Rudolf Steiner para os estudos literários. Espera-se contribuir para a ressignificação do papel da literatura como força impulsora na mediação entre o sentimento e a razão para o desenvolvimento e constituição do pensar conceitual e formação do ser harmônico e integral. Esta tese contém uma introdução e seis capítulos. O capítulo 1 dá uma ideia geral do contexto de Rudolf Steiner e trata de sua formação, carreira, interesses profissionais, bem como sobre algumas possíveis influências sobre seu pensamento. O capítulo 2 apresenta as concepções do homem, do querer, do sentir e do pensar que aparecem na obra Filosofia da Liberdade e suas relações com outros estudos do autor. Discute também a importância da arte e das narrativas para a formação do ser humano integral, harmônico e espiritualmente livre. O capítulo 3 compara as ideias de Steiner acerca do pensar, da criança, das narrativas com as concepções de Edgar Morin e Walter Benjamin. Também apresenta indicações de narrativas propostas por seguidores de Steiner. O capítulo 4 apresenta a metodologia e as obras utilizadas na experiência estética de recepção de leitura desenvolvida com ex-alunos formados pela pedagogia Waldorf e exalunos formados por outras pedagogias. $O$ capítulo 5 discute os resultados da pesquisa. $O$ capítulo 6 apresenta algumas considerações finais sobre o assunto.

Palavras-chave: Literatura Infantil, Leitura, Sentir e Pensar, Recepção da Leitura, Experiência Estética, Rudolf Steiner, Os Atos da Vontade. 


\begin{abstract}
MUTARELLI, Sandra R. Kuka. Rudolf Steiner's willing, feeling and thinking in the literature for children and youngsters: the acts of will. $301 \mathrm{p}$. Thesis (Doctoral). Philosophy, Languages and Human Sciences College, University of São Paulo. Brazil. 2014.
\end{abstract}

Rudolf Steiner (1861-1925) was a philosopher, journalist and educator. Nowadays his name is usually associated with the Camphill moviment of curative education, architecture, biodynamical agriculture, the anthroposophical medicine, several studies on religion and the Waldorf education. The aim of this research is to examine the contribution and validity of Rudolf Steiner's concepts of willing, feeling and thinking that may be seen in literary studies. This work is expected to render some contrtibution to resignifying the role of literature as a thrust in mediating feelings and reason in order to develop and constitute conceptual thinking as well as in forming a harmonious and wholesome being. This thesis contains an introduction and six chapters. Chapter 1 provides a general overlook of Steiner's context and deals with his background, career, professional interests as well as some of the possible influences he received. Chapter 2 studies Steiner's concepts of man, willing, feeling and thinking presented in his work The Philosophy of Freedom as well as in other works by Steiner. It also discusses the importance of Art and the importance of narrative to form a wholesome and harmonious being who is also spiritually free. Chapter 3 compares Steiner's ideas about thinking, about the child and about the narratives that follow conceptions by Edgar Morin and Walter Benjamin. It also presents indications of narrative proposed by Steiner's followers. Chapter 4 presents the methodology and the works used in the aesthetic experience of reading reception, which was developed with alumni graduated in Waldorf and alumni graduated in other pedagogies. Chapter 5 discusses the results of the research. Chapter 6 presents some final thoughts on the subject.

Key Words: Children Literature, Reading, Feeling and Thinking, Reading Reception, Aesthetic Experience, Rudolf Steiner, Acts of Will. 


\section{LISTA DE FIGURAS}

Figura 1.1 - Foto de Rudolf Steiner de 1879. Referência disponível na internet: http://uncletaz.com/steinerphotos/stein13.html

Figura 1.2 - Foto de Rudolf Steiner de 1896. Referência disponível na internet: http://uncletaz.com/steinerphotos/steinmar.html

Figura 1.3 - Foto de Rudolf Steiner e Marie von Sivers de 1908. Referência disponível na internet: http://uncletaz.com/steinmar.html.

Figura 1.4 - Foto do primeiro Goetheanum construído em Dornach, Suiça, em 1922.

Disponível na internet: http://uncletaz.com/goetheanum.html

Figura 1.5 - Foto do segundo Goetheanum construído em Dornach, Suiça em 1929

Disponível na internet: http://uncletaz.com/goetheanum.html

Figura 1.6 - Foto de Rudolf Steiner de 1919. Referência disponível na internet: http://uncletaz.com/steinerphotos/stein23.html

Figura 2.1 - Desenho ilustrativo da concepção do homem tetramembrado de Steiner ................69

Figura 4.1 - Ilustração do poema Pobre Vovô! ...................................................................... 164

Figura 4.2 - Ilustração do poema Vocês Acreditam? ............................................................... 166

Figura 4.3 - Ilustração da obra Vi uma Estrela lá fora........................................................ 170

Figura 4.4 - Ilustração da obra Vi uma Estrela lá fora............................................................. 171

Figura 4.5 - Ilustração da obra Vi uma Estrela lá fora........................................................ 172

Figura 4.6 - Ilustração da obra Vi uma Estrela lá fora............................................................. 173

Figura 4.7 - Ilustração da obra Vi uma Estrela lá fora.......................................................... 174

Figura 4.8 - llustração da obra Vi uma Estrela lá fora.......................................................... 174

Figura 4.9 - Ilustração da obra Vi uma Estrela lá fora........................................................... 175

Figura 4.10 - Ilustração da obra Vi uma Estrela lá fora........................................................ 176

Figura 4.11 - Ilustração da obra Vi uma Estrela lá fora ....................................................... 178

Figura 4.12 - Ilustração da obra Vi uma Estrela lá fora........................................................... 178

Figura 4.13 - Ilustração da obra Vi uma Estrela lá fora........................................................ 179

Figura 4.14 - Ilustração da obra Vi uma Estrela lá fora .......................................................... 181

Figura 4.15 - Ilustração da obra O Beijo da Palavrinha ....................................................... 192

Figura 4.16 - Ilustração da obra O Beijo da Palavrinha ............................................................. 193

Figura 4.17 - Ilustração da obra O Beijo da Palavrinha ...................................................... 194

Figura 4.18 - Ilustração do quadro A princesa arrastando o manto de Malagantana ................. 195

Figura 4.19 - Ilustração da obra $O$ Beijo da Palavrinha ......................................................... 195

Figura 4.20 - Ilustração da obra O Beijo da Palavrinha ........................................................... 196

Figura 4.21 - Ilustração da obra O Beijo da Palavrinha ........................................................ 197

Figura 4.22 - Ilustração da obra O Beijo da Palavrinha ........................................................... 199

Figura 4.23 - Ilustração da obra O Beijo da Palavrinha ......................................................... 200

Figura 4.24 - Ilustração da obra O Beijo da Palavrinha ........................................................ 201

Figura 4.25 - Ilustração da obra O Beijo da Palavrinha ......................................................... 202

Figura 4.26 - Ilustração da obra O Beijo da Palavrinha ........................................................... 203 
Figura 4.27 - Ilustração da obra O Beijo da Palavrinha ....................................................... 204

Figura 4.28 - Ilustração da obra O Beijo da Palavrinha .............................................................. 205

Figura 4.29 - Ilustração da obra O Beijo da Palavrinha ........................................................... 206

Figura 4.30 - Ilustração da obra A Moça Tecelã................................................................ 208

Figura 4.31 - Ilustração da obra A Moça Tecelã.................................................................. 209

Figura 4.32 - llustração da obra A Moça Tecelã................................................................ 210

Figura 4.33 - Ilustração da obra A Moça Tecelã.................................................................... 212

Figura 4.34 - Ilustração da obra A Moça Tecelã............................................................... 213

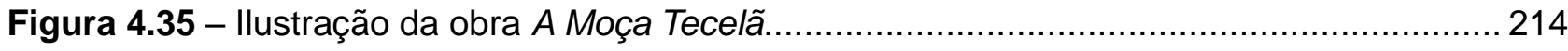

Figura 4.36 - Ilustração da obra A Moça Tecelã............................................................... 214

Figura 4.37 - Ilustração da obra A Moça Tecelã............................................................. 215 


\section{SUMÁRIO}

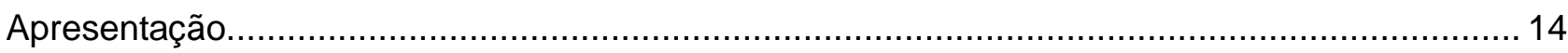

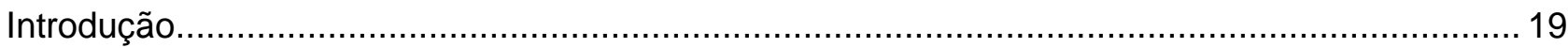

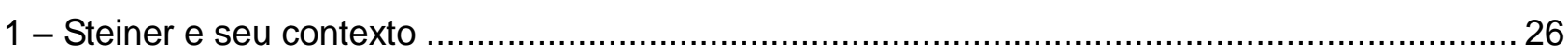

1.1 Formação e possíveis influências ......................................................................... 26

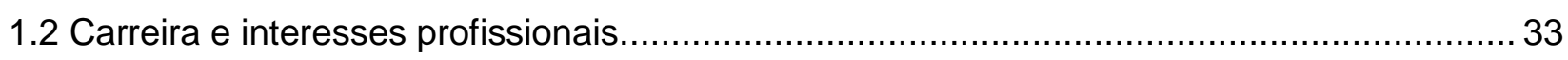

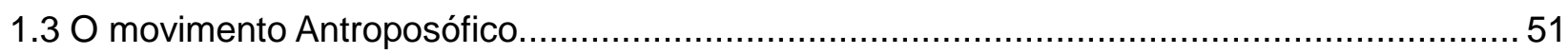

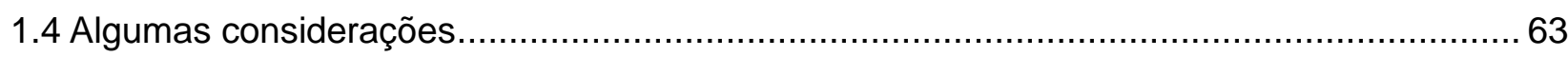

2 - Concepções do homem, do pensar, do querer e do sentir em Steiner ................................6 66

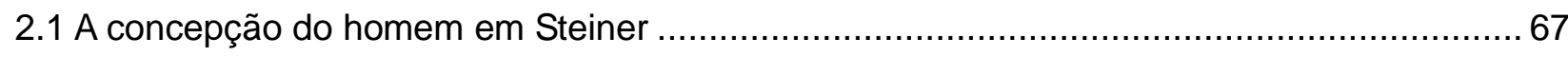

2.2 A concepção do pensar e do sentir em Steiner ............................................................... 70

2.3 A concepção do querer em Steiner ....................................................................... 76

$2.4 \mathrm{O}$ querer, o sentir e o pensar aplicados à educação ...................................................... 80

$2.5 \mathrm{~A}$ atuação das narrativas no querer, no sentir e no pensar ............................................. 94

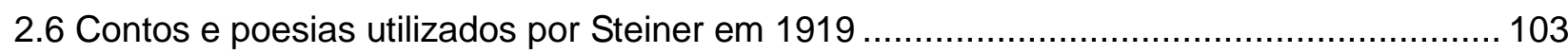

3 - Steiner em diálogo com outros pensadores: uma comparação ....................................... 118

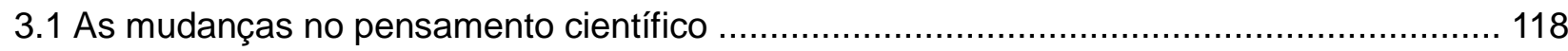

3.2 O Eu e o pensar em Rudolf Steiner e em Edgar Morin ................................................. 121

3.3 Criança e narrativas em Rudolf Steiner e em Walter Benjamin.......................................... 130

3.4 Indicações de narrativas propostas por seguidores de Steiner ...................................... 137

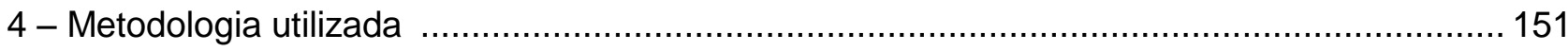

4.1 Seleção do grupo e definição do questionário ....................................................... 151

4.2 Apresentação das obras escolhidas ................................................................ 158

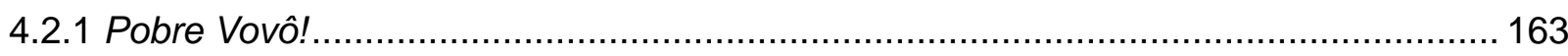

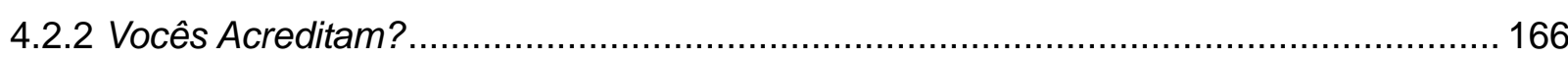

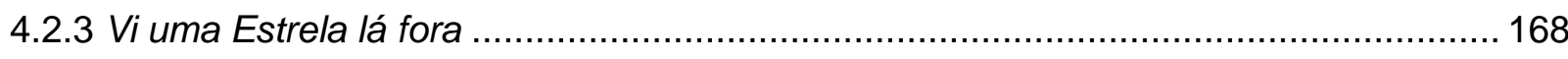

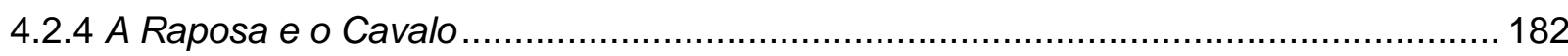

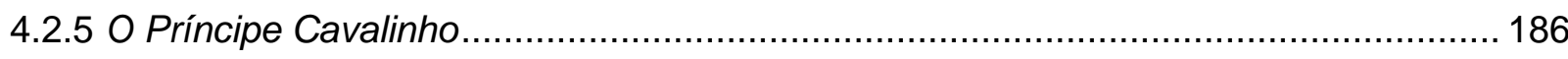

4.2.6 O Beijo da Palavavrinha ...................................................................................... 190

4.2.7 A Moça Tecelã ................................................................................................... 207

4.3 Método utilizado na experiência estética de recepção da leitura ................................... 218

5 - Apresentação dos resultados da pesquisa ................................................................. 222

5.1 Apresentação dos ambientes em que a pesquisa foi realizada ...................................... 222

5.2 Apresentação dos resultados das respostas ao questionário um.................................... 225

5.3 Apresentação dos resultados da experiência estética de recepção da leitura................... 245

5.4 Algumas considerações sobre os resultados obtidos............................................... 271

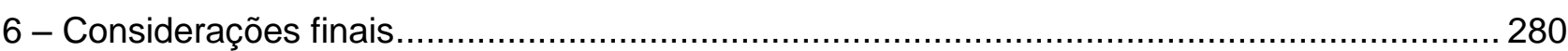

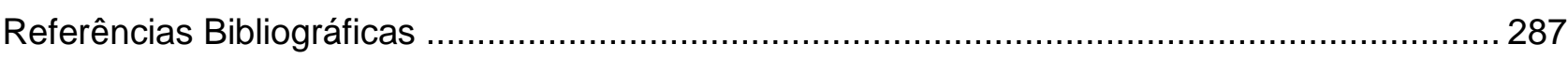

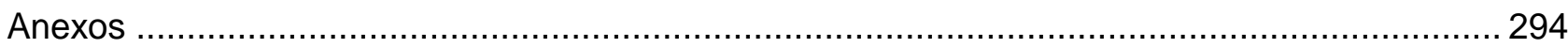




\section{APRESENTAÇÃO}

“Há um Deus dentro de mim, Há um mundo ao meu redor. Se estiver ouvindo o mundo, Ao meu Deus ouço melhor." Rudolf Steiner

Esta apresentação é um depoimento pessoal que busca elucidar os caminhos por mim percorridos até chegar às questões presentes nesta tese.

O que mais me atraiu no programa de Pós-Graduação em Estudos Comparados de Literaturas de Língua Portuguesa foi a possibilidade de poder aproximar a literatura de outros domínios da expressão ou do conhecimento e poder dar prosseguimento aos estudos realizados no Mestrado. Outra característica importante, foi o fato de ser uma área interdisciplinar, podendo atuar em vários campos do conhecimento, fato que vai ao encontro do percurso empreendido por mim no decorrer de minha vida estudantil e profissional.

Bacharel em Matemática pela Universidade Presbiteriana Mackenzie, especialista em Magistério do Ensino Superior pela Universidade Paulista - UNIP, licenciada em Inglês no curso de Complementação Pedagógica da Universidade Presbiteriana Mackenzie, Mestre em História da Ciência pela Pontifícia Católica de São Paulo - PUC, com a tese: "Os Quatro Temperamentos na Antroposofia de Rudolf Steiner".

Professora universitária de Matemática e Inglês para os cursos de Administração, Comércio Exterior e Letras, coordenadora de cursos distintos como: Administração de Empresas e Cursos Superiores de Tecnologia em Comércio 
Exterior e Gestão (Financeira, Logística, Marketing, Processos Gerenciais e Recursos Humanos) e diretora do campus Cidade Universitária da Universidade Paulista - UNIP. Por acaso, ou destino, durante dois anos e meio (1995-1997) fui professora de inglês na Escola Waldorf Rudolf Steiner de São Paulo. Foi quando conheci a Antroposofia e a Pedagogia Waldorf.

Entre a qualificação e a defesa do Mestrado, conheci o professor Dr. José Nicolau Gregorin Filho, o que possibilitou a matrícula como aluna especial na disciplina "Temas de Literatura Infantil/Juvenil: Um Percurso Comparativo" do Programa de Estudos Comparados de Literaturas de Língua Portuguesa. Posteriormente, cursei a disciplina "Literatura Infantil: Sincretismos de Linguagens, Percepção e Imaginário".

Retomei, então, as leituras das obras de Steiner, buscando e aprofundando meus conhecimentos nos temas ligados à educação e, especificamente, à Literatura, que não haviam sido explorados com profundidade nos estudos realizados para o Mestrado.

As disciplinas cursadas como aluna especial, já na área de Estudos Comparados de Literaturas de Língua Portuguesa associadas às concepções de Steiner, renovaram minha vontade de prosseguir como aluna regular. Passei a me interessar por autores que viveram na época da cisão entre Arte e Ciência, principalmente aqueles que defendiam a Arte e sua contribuição na formação do ser humano.

Assim, surgiu o pré-projeto para ingresso na área: "Literatura Infantil: Um Olhar Antroposófico" que, como todo projeto, no decorrer do percurso, sofreu alterações. O contato com outros autores e o aprofundamento na área nas duas 
disciplinas cursadas como aluna regular do programa ("Leitura, Literatura e Educação no Brasil" e "Níveis de Leitura Intertextual Enquanto Autoria e Recepção em Obras Literárias de Língua Portuguesa: da Criança ao Adulto"), redirecionaram o pré-projeto e corroboraram para a mudança na orientação que passou do professor Dr. José Nicolau Gregorin Filho para a professora Dra. Maria dos Prazeres Santos Mendes. Mudança que ocorreu em virtude de um interesse maior pelos estudos na área da estética e da recepção da leitura, além de uma tendência na pesquisa de base mais formalista, embora levando em conta os estudos recentes que consideram as contribuições dos estudos de base conteudista.

Atrelado aos estudos e pesquisas realizadas até o momento, o percurso profissional por mim percorrido corroborou para a proposta aqui apresentada.

Acredito ser pertinente qualquer discussão que vise melhorar a formação dos jovens no Brasil, visto que, a cada ano que passa, vários desses jovens chegam cada vez menos preparados para a graduação, para a vida, para o mundo. É possível perceber uma queda qualitativa considerável em habilidades básicas de leitura, escrita e raciocínio lógico em muitos calouros de universidades particulares, que atendem a grande massa da população brasileira. Realidade testemunhada por mim nos vinte e dois anos de trabalho realizados em uma instituição particular de ensino universitário, que é responsável pela formação de um número expressivo de futuros cidadãos e profissionais da cidade de São Paulo.

A defasagem nas habilidades acima citadas, comprometem a formação desses jovens, afetando a maneira como se expressam, se reconhecem e se relacionam com o mundo e com seus semelhantes.

A imagem do homem que norteia a Pedagogia Waldorf exige que esse, como 
indivíduo "espiritual", anímico e físico, lute para realizar a sua imagem arquetípica. Lute para combater as forças mecanicistas que combatem sua vontade e se coloque em condições de julgar e buscar um ideal. A pedagogia Waldorf é uma pedagogia voltada à criança e ao adolescente e tem a finalidade de prepará-los para a vida, formando o homem que busca a sua autorrealização de acordo com a sua natureza intrínseca, sua evolução histórica e a sua posição no cosmo.

É através da existência pelo desejo, isto é, do esforço do homem por existir e do seu desejo de ser, que o homem estabelece relações com outros homens, utilizando-se da linguagem, com seus signos e símbolos para exprimir ou reprimir seus desejos e relacionar-se com os outros homens. Inserido em uma comunidade, com valores religiosos, culturais, morais, etc., o homem expressa suas ideias, seus sonhos, suas opiniões.

Educar pelo sentimento era a chave para Steiner, pois é justamente no sentir que encontram-se os embriões para o conhecer e para os atos da vontade, daí a importância dada em sua educação para um correto desenvolvimento da vida sentimental da criança, que deve ter esperança, desejo, expectativas em relação à vida.

A partir destas considerações, passei a pensar nos jovens recém formados no Ensino Médio em escolas públicas e estaduais, pois é com esse adulto que lido em minha formação e prática educacional, há mais de vinte e dois anos. E esse jovem adulto está muito distante do adulto idealizado por Rudolf Steiner e outros pensadores da sua época. Passei a questionar o que poderia ser feito para resgatar ou revivificar esse estado de puro sentir, considerados por Steiner, como embrionários para o conhecer e para o agir. Chegando, desta forma, as duas 
perguntas que nortearam esta pesquisa: "Será que isso é possível por meio da literatura?" e "O que acontece quando um jovem adulto tem em suas mãos um livro infantil e o utiliza da maneira proposta por Steiner?". 


\section{INTRODUÇÃO}

A partir das reflexões teóricas desenvolvidas no campo da produção estética e da recepção da leitura, este estudo visa contribuir para a ressignificação do papel da literatura para o jovem ou os adultos em geral, por meio da aproximação desses estudos com as concepções desenvolvidas por Rudolf Steiner (1861-1925) com relação ao querer, ao sentir e ao pensar. Literatura que deve ser entendida não apenas como veiculadora de saberes formais e valores morais, mas principalmente como força impulsora na mediação entre o "coração" e o intelecto para o desenvolvimento e constituição do pensar conceitual.

Espera-se com este estudo, demover a ideia de construção do conhecimento e enfatizar a constituição do conhecimento que só pode ser obtido por meio da relação sentimento e razão. Esta relação está diretamente relacionada à forma como as coisas significam e são representadas por cada ser individual. A ideia é devolver à literatura seu papel de arte. É a contribuição essencial do estético, da arte, por meio de seu poder de abdução, para a formação do ser harmônico e integral.

O aporte teórico que permitiu a inserção desta tese na área de Estudos Comparados de Literatura ancora-se nas definições de Literatura Comparada propostas por Henry H. H. Remak, Claude Pichois, André Rousseau, Álvaro Manuel Machado e Daniel-Henri Pageaux.

Remak considera que embora haja discordância com relação aos aspectos teóricos da literatura comparada, há um consenso com relação à sua tarefa. Segundo ele, é por meio dela que estudiosos, professores, estudantes e leitores, poderão ter uma completa e melhor compreensão da literatura como um todo. $\mathrm{E}$, a 
melhor forma de chegar a essa compreensão, pode ser obtida ao se "relacionar a literatura a outros campos do conhecimento e da atividade humana, especialmente os campos artísticos e ideológicos" (COUTINHO e CARVALHAL, 1994:181). Por isso, ele propõe estender a investigação e os estudos literários não só geográfica, mas também genericamente. Em suma, a definição proposta por Remak é a "comparação de uma literatura com uma outra ou outras, e a comparação da literatura com outras esferas da expressão humana" (COUTINHO e CARVALHAL, 1994:175).

Claude Pichois e André Rousseau defendem a ideia de que é possível estudar a literatura sem levar em conta o tempo ou o lugar, visto que ela é, assim como a arte, a religião, a política, entre outros, uma manifestação específica da atividade "espiritual" humana. Para eles, a literatura comparada busca laços de analogia, de parentesco e de influência visando aproximar a literatura de outros domínios da expressão ou do conhecimento. Pichois e Rousseau consideram que a literatura comparada é uma arte metódica que busca comparar os fatos ou os textos visando descrevê-los, compreendê-los e saboreá-los melhor (COUTINHO e CARVALHAL, 1994:216-218).

Remak, Pichois e Rousseau consideram possível o estudo literário sem levar em conta o tempo e o lugar, o que assegura o estudo de um conhecimento distante geograficamente, produzido fundamentalmente na Alemanha no final do século XIX e início do século XX. Eles também consideram frutífera a busca por laços de analogias que visem aproximar a literatura de outras esferas, de outros domínios da expressão ou do conhecimento, abrindo, assim, um leque de possibilidades de estudos de concepções produzidas por diferentes pensadores de áreas distintas. 
Álvaro Manuel Machado e Daniel-Henri Pageaux defendem a ideia de que a base fundamental da Literatura Comparada, seu princípio dialógico está inserido "no próprio centro do espaço conhecido (o da cultura do investigador), retomando-o e revitalizando-o". Para os autores, o contato por meio da tradução de uma obra estrangeira, no caso específico desta tese, as traduções das ideias e concepções de Rudolf Steiner, é "também interpretação, portanto, representação duma realidade estrangeira adaptada a uma outra sensibilidade", ao imaginário - "a outras formas de dizer o homem, os sentimentos, o espaço, as relações com a sociedade". Os autores justificam essa viagem, por meio da palavra e das imagens que se formam ao interrogar e buscar compreender a produção de Rudolf Steiner (MACHADO \& PAGEAUX, 2001:27).

As fontes primárias de Rudolf Steiner utilizadas nesta tese foram localizadas principalmente no site oficial Alemão, no site Americano, na Biblioteca da Escola Waldorf Rudolf Steiner e na Biblioteca da Sociedade Beneficente Antroposófica de São Paulo. Realizamos a fundamentação das ideias deste autor por meio da leitura e cotejamento dos livros publicados em quatro idiomas: alemão, inglês, espanhol e português.

Há três justificativas para a escolha do estudo das ideias de Rudolf Steiner e não outro pensador. A primeira justificativa está relacionada ao período histórico em que Steiner viveu, visto que essa época é herdeira das discussões e posterior cisão entre Arte e Ciência. Steiner está entre os pensadores que se opuseram a esta cisão, assim como pensadores da atualidade, como é o caso de Edgar Morin. A segunda justificativa está relacionada à definição de Steiner sobre os atos da vontade, que são determinados pelo querer, pelo sentir e pelo pensar, e se 
constituem, individual e coletivamente, por meio das representações e da significação, por meio das imagens que representam o mundo e as relações que o homem estabelece com os outros homens e com si mesmo. A terceira justificativa está relacionada à importância atribuída por ele às narrativas, consideradas como facilitadoras na integração da parte espiritual-individual da criança à própria corporalidade e facilitadoras da sua adaptação e autonomia futura em sua vida terrestre.

É interessante constatar que, apesar de Rudolf Steiner ter falecido em 1925, a prática pedagógica fundada por ele continua viva em todas as escolas Waldorf ao redor do mundo, em diferentes países, noventa e cinco anos após a sua morte. Alunos formados por essa pedagogia continuam a ouvir histórias narradas por seus professores e a recitar versos do Jardim de Infância até o décimo segundo ano da vida escolar. Essa característica particular da pedagogia Waldorf embasou o método utilizado na experiência estética de recepção da leitura proposta para a pesquisa de campo que fundamenta esta tese.

Cumpre esclarecer que a primeira escola fundada por ele, em 1919, visava a educação dos filhos de operários de uma fábrica de cigarros em Stuttgart chamada Waldorf-Astoria. E é do nome dessa fábrica de cigarros que vem o nome da pedagogia. Com o passar do tempo, as escolas que adotam esta pedagogia elitizaram-se atendendo principalmente a classe com maior poder aquisitivo, aos filhos de grandes empresários, artistas, entre outros. Este fato pode ser facilmente comprovado nas escolas do Brasil. E foi justamente o incômodo causado pela elitização das concepções de Steiner que norteou a vontade de trazer essa prática do uso de narrativas para outras esferas, para outras pedagogias, para os jovens e 
adultos em geral.

Educar pelo sentimento era a chave para Steiner, pois é justamente no sentir que se encontram os embriões para o conhecer e para os atos da vontade. Daí a importância, dada em sua educação, para um correto desenvolvimento da vida sentimental da criança, que deve ter esperança, desejos, expectativas em relação à vida.

A partir destas considerações, passamos a pensar no adulto formado por escolas públicas e estaduais, pois é com esse adulto que lidamos em nossa formação e prática educacional há mais de vinte e dois anos. E esse adulto está muito distante do adulto idealizado por Rudolf Steiner e por outros pensadores do seu tempo, como é o caso de Walter Benjamin, e do nosso tempo. Na maioria das vezes, apresenta dificuldades graves de aprendizagem, raciocínio lógico, escrita, leitura. Além disso, a grande maioria não gosta de ler, tem dificuldade em interpretar os textos e, consequentemente, a vida.

Passamos a questionar o que poderíamos fazer para resgatar ou revivificar esse olhar de criança, olhar de descoberta, curiosidade, criatividade e imaginação, estados de puro sentir, considerados por Steiner, como embrionários para o conhecer e para o agir. Será que isto é possível por meio da literatura? O que acontece quando um jovem adulto tem em suas mãos um livro infantil e o utiliza da maneira proposta por Steiner?

Para responder essas questões, elaboramos uma experiência estética de recepção da leitura utilizando dois poemas de Helena Pinto Vieira (Pobre Vovô! e Vocês Acreditam?), a obra Vi uma Estrela lá fora de Regina Chamlian, o conto $A$ Raposa e o Cavalo da coletânea dos Irmãos Grimm, a narrativa O Príncipe 
Cavalinho da obra Contos e Fábulas do Brasil, as obras O Beijo da Palavrinha de Mia Couto e A Moça Tecelã de Marina Colasanti. Antes de realizá-la, selecionamos alunos formados pela pedagogia Waldorf e alunos formados por outras pedagogias para avaliar, por meio de uma pesquisa exploratória, semelhanças e diferenças com relação aos interesses e hábitos de leitura literária e posicionamento em relação às questões essenciais da vida. O que pensam sobre a vida, a morte e a velhice? Quais são seus medos? Visto que estes são os temas abordados nas obras escolhidas.

Esperamos que esta pesquisa possa contribuir para uma reflexão e posterior adequação dos conteúdos propostos aos universitários em disciplinas como Interpretação e Produção de Textos e Comunicação e Expressão, de forma a minimizar as lacunas provenientes do Ensino Fundamental e Médio apontadas acima. Esperamos, também, que abra novas perspectivas aos professores de escolas da rede pública e estadual, sobre o uso da leitura literária em sala de aula. Uso que não deve ser entendido como forma de ensinar gramática ou interpretação de texto, mas como interface entre o sentimento e a razão, capaz de proporcionar um estado de encantamento, de puro "sentir", que alimenta a alma e transfigura o pensar, o conhecer, impulsionando à ação.

Consideramos importante esclarecer que, em momento algum pretendemos discutir situações relacionadas à educação ou práticas educacionais, nem tampouco, questões relacionadas à prática de leitura literária nas escolas em geral durante o Ensino Fundamental ou Médio. Sabemos da importância destes temas, porém nos afastariam da particularidade de nossa hipótese inicial que diz respeito ao uso das narrativas, conforme proposto por Steiner, como facilitadoras na atuação 
do sentir no querer e no pensar para a formação do ser harmônico e integral.

Esta tese é composta por esta Introdução e seis capítulos. O primeiro capítulo ("Steiner e seu contexto") tratará da formação, carreira, interesses profissionais e de algumas das possíveis influências sobre o pensamento de Steiner em relação ao movimento antroposófico, dando uma ideia geral do contexto da época. O segundo capítulo ("Concepções do homem, do pensar, do querer e do sentir em Steiner") apresentará, a partir das obras originais $A$ Filosofia da Liberdade e $A$ Arte da Educação I, II, III, as concepções do homem, do pensar em relação ao sentir e do querer em relação ao sentir em Steiner. Em seguida, apresentará suas ideias sobre a importância da arte e das narrativas para a formação do ser humano integral, harmônico e espiritualmente livre. Finalizará com a apresentação dos contos e poesias utilizados por Steiner em 1919. O terceiro capítulo ("Steiner em diálogo com outros pensadores: uma comparação") apresentará uma comparação entre as ideias de Steiner, Walter Benjamin, entre outros. Em seguida, apresentará indicações de narrativas propostas por seguidores de Steiner de escolas brasileiras da atualidade. O quarto capítulo ("Metodologia utilizada”) explicará os critérios para seleção dos participantes da pesquisa de campo, os questionários utilizados e as obras selecionadas para a experiência estética de recepção de leitura. O quinto capítulo ("Apresentação dos resultados da pesquisa”) apresentará os participantes da pesquisa bem como os ambientes em que foi realizada, os resultados obtidos na pesquisa exploratória e na experiência estética de recepção de leitura. $\mathrm{O}$ sexto capítulo conterá as Considerações Finais e procurará responder as questões propostas nesta tese. 


\section{STEINER E SEU CONTEXTO}

Este capítulo discutirá, inicialmente, acerca da formação, carreira e interesses profissionais de Rudolf Steiner (1861-1925). Procurará também dar uma ideia do panorama geral, inclusive em termos científicos, do que existia na época em que ocorreu sua formação, publicação de trabalhos e atuação como palestrante em diversos países.

\subsection{FORMAÇÃO E POSSÍVEIS INFLUÊNCIAS}

Rudolf Steiner nasceu em Kraljevec na Hungria, na divisa entre a Europa Central e a Oriental (fronteira húngaro-croata), em 27 de fevereiro de 1861. Filho de Johann Steinner (1829 - 1910) e Franziska Steiner (1834 - 1918), ambos procedentes da Baixa Áustria. Seu pai, que era caçador, abandonou esta profissão para constituir família, tornando-se telegrafista a serviço da Estrada de Ferro do Sul da Áustria (HEMLEBEN, 1989:12-13).

Por conta da profissão de seu pai, que era constantemente transferido, a família permaneceu em Kraljevec por apenas um ano e meio, mudando-se para Mödling, perto de Viena, onde permaneceu por meio ano. Em seguida, a família mudou-se para Pottschach, onde Steiner passou a infância (dos 2 aos 8 anos de idade). Em Pottschach nasceram seu irmão e sua irmã. De lá, a família mudou-se para Neudörf, uma pequena aldeia húngara, a uma hora de Wiener-Neustadt 
(HEMLEBEN, 1989:13-18).

Dos oito aos dez anos de idade, Steiner frequentou a escola local de Neudörf. Era uma escola simples, com apenas uma sala de aula, onde meninos e meninas de diferentes idades participavam das aulas juntos. Nessa época, Steiner interessou-se por um livro de geometria que viu sobre a mesa de um de seus professores e de tempos em tempos tinha autorização para levá-lo para sua casa. Em sua autobiografia, Steiner comentou acerca de seu encantamento pelos triângulos, quadrados, polígonos etc. e, particularmente, pelo teorema de Pitágoras. Ele relatou que, durante sua infância, antes dos oito anos de idade, costumava dividir as coisas mentalmente em duas categorias: as "visíveis" e as "não visíveis". Para ele, a geometria podia explicar, também, as coisas "espirituais", não físicas, "não visíveis", experimentadas apenas pela mente (HEMLEBEN, 1989:18-20) ${ }^{1}$.

Na escola acima mencionada, Steiner interessou-se também pela arte através do contato com um de seus professores, que, além de tocar piano e violino, desenhava e o ensinou a desenhar com crayon e a apreciar a música dos ciganos húngaros (STEINER, 1985:20-23).

Durante os anos em que viveu em Neudörf, Steiner também participou de aulas de religião ministradas por um padre que também era um dos responsáveis pela direção da escola. Com este, Steiner e seus colegas discutiam sobre política bem como sobre o sistema astronômico copernicano (STEINER, 1985:24-26).

Steiner conviveu com o médico da cidade de Wiener-Neustadt, que

\footnotetext{
${ }^{1}$ Anos mais tarde, no livro A Arte da Educação I, traduzido do livro Allgemeine Menschenkunde als Grundlage der Pädagogik baseado em uma conferência proferida por ele no dia 23 de agosto de 1919, Steiner comentou que: "Esses movimentos que os Amigos fixam na geometria, ao fazer figuras geométricas, os Senhores executam com a Terra. (...) O homem está integrado no Cosmo. Enquanto está desenvolvendo a geometria, imita o que ele próprio faz no Cosmo". Ele concluiu que, uma das diferenças entre o homem e o animal é a posição de sua medula espinhal, que por estar na vertical, e não na horizontal, permite que o homem, sem perceber, execute movimentos geométricos ao se movimentar na Terra. (pp. 49-50).
} 
costumava conversar com ele após visitar seus pacientes, enquanto aguardava pelo trem em Neudörf. Através dele, interessou-se pela literatura alemã, por Gotthold E. Lessing, Johann Wolfgang Goethe e Friedrich Schiller (STEINER, 1985:29)². Além disso, Steiner interessou-se pela dinâmica da estação de trem, onde aprendeu sobre os princípios de eletricidade e como usar o telégrafo (STEINER, 1985:30).

A partir do décimo ano de vida, Steiner frequentou o liceu ${ }^{3}$ na cidade de Wiener-Neustadt. Dos doze aos treze anos, adquiriu conhecimentos sobre geometria descritiva e o cálculo de probabilidade, incentivado por dois professores, Laurenz Jelinek (físico e matemático) e Georg Kosak (professor de Geometria) (HEMLEBEN, 1989:22-23). Steiner comentou que, nessa época, passando por uma livraria viu um artigo sobre a Crítica da Razão Pura de Kant e que fez de tudo para adquirir o livro (STEINER, 1985:38).

Em sua autobiografia, Steiner comentou sobre sua leitura da Crítica da Razão Pura de Kant e, também, sobre diversos livros que tratavam dos símbolos e dogmas da Igreja, descreviam seus serviços e traziam informações sobre sua história (STEINER, 1985:40).

Por volta de 1876, Steiner voltou a encontrar o médico de Wiener-Neustadt, que Ihe emprestou vários livros, entre eles o Minna von Barnhelm ("Minna de Barnhelm") de Gotthold E. Lessing 4 . Este médico e Steiner passaram a se encontrar regularmente para conversar sobre os assuntos tratados nos livros que Steiner havia lido. Nesta mesma época, os estudos de matemática tornaram possível a leitura do livro The General Motion of Matter as the Fundamental Cause of all the Phenomenon

\footnotetext{
${ }^{2}$ Sobre as relações entre Romantismo alemão e ciência ver, por exemplo, Alexander Godê-Von Aesche, Natural Science in German Romanticism.

${ }^{3} \mathrm{Na}$ época, havia dois tipos de escolas secundárias: o Ginásio ou o Liceu. O currículo do Ginásio dava mais ênfase aos clássicos, enquanto que o do Liceu dava ênfase à ciência e às línguas modernas.

${ }^{4}$ Lessing (1729-1781), escritor e filósofo alemão que discutia temas como verdade e liberdade.
} 
of Nature ${ }^{5}$, escrito pelo diretor da escola. Foi também nesse período que Steiner passou a monitorar seus colegas em língua e literarura alemã (STEINER, 1985:4144). O estudo das obras de poetas gregos e latinos, a partir de sua tradução para o alemão, despertou em Steiner o interesse pelas línguas clássicas (STEINER, 1985:48).

Steiner cursava o liceu por vontade de seu pai que queria que ele fosse engenheiro. Ao mesmo tempo, sentia vontade de conhecer as línguas clássicas que eram ensinadas no ginásio. Ele, então, adquiriu manuais de línguas grega e latina e passou a estudá-los nas horas vagas. Mais tarde, ministrou aulas de suplementação nas línguas clássicas para alunos do ginásio (HEMLEBEN, 1989:24).

Em 1879, a família mudou-se para Inzerdorf, localizada próximo a Viena, onde Steiner cursaria a Academia Técnica. Ele se inscreveu nas disciplinas de matemática, biologia, física e química (HEMLEBEN, 1989:24-26). (Ver figura 1.1).

Steiner contou em sua autobiografia que sua primeira visita à Viena foi motivada pelo desejo de comprar uma série de livros sobre filosofia. Foi quando leu Theory of Science ("Teoria da Ciência") de Johann Gottlieb Fichte e outros três tratados do mesmo autor: The Vocation of the Scholar ("A Vocação do Estudioso"), The Nature of the Scholar6 e Addresses to the German Nation? ("Discursos à Nação Alemã), o qual mais o impressionou. Tais leituras fizeram com que seu interesse por Kant aumentasse e Steiner leu Prolegômenos a qualquer Metafísica Futura que possa vir a ser considerada como Ciência (Prolegomena zu einer jeden Künftigen

\footnotetext{
5 Título em alemão: Die allgemeine Bewung der Materie als Grundursache aller Naturescheinungen. Optamos por não colocar o título em português, pois não encontramos nenhuma referência em relação à tradução deste livro para a língua portuguesa.

${ }^{6}$ Optamos por não colocar o título em português, pois não temos certeza se foi traduzido para o nosso idioma.

${ }^{7}$ Títulos originais em Alemão: Über die Bestimmung des Gelehrten, Über das Wesen des Gelehrten e Reden an die Deutsche Nation.
} 


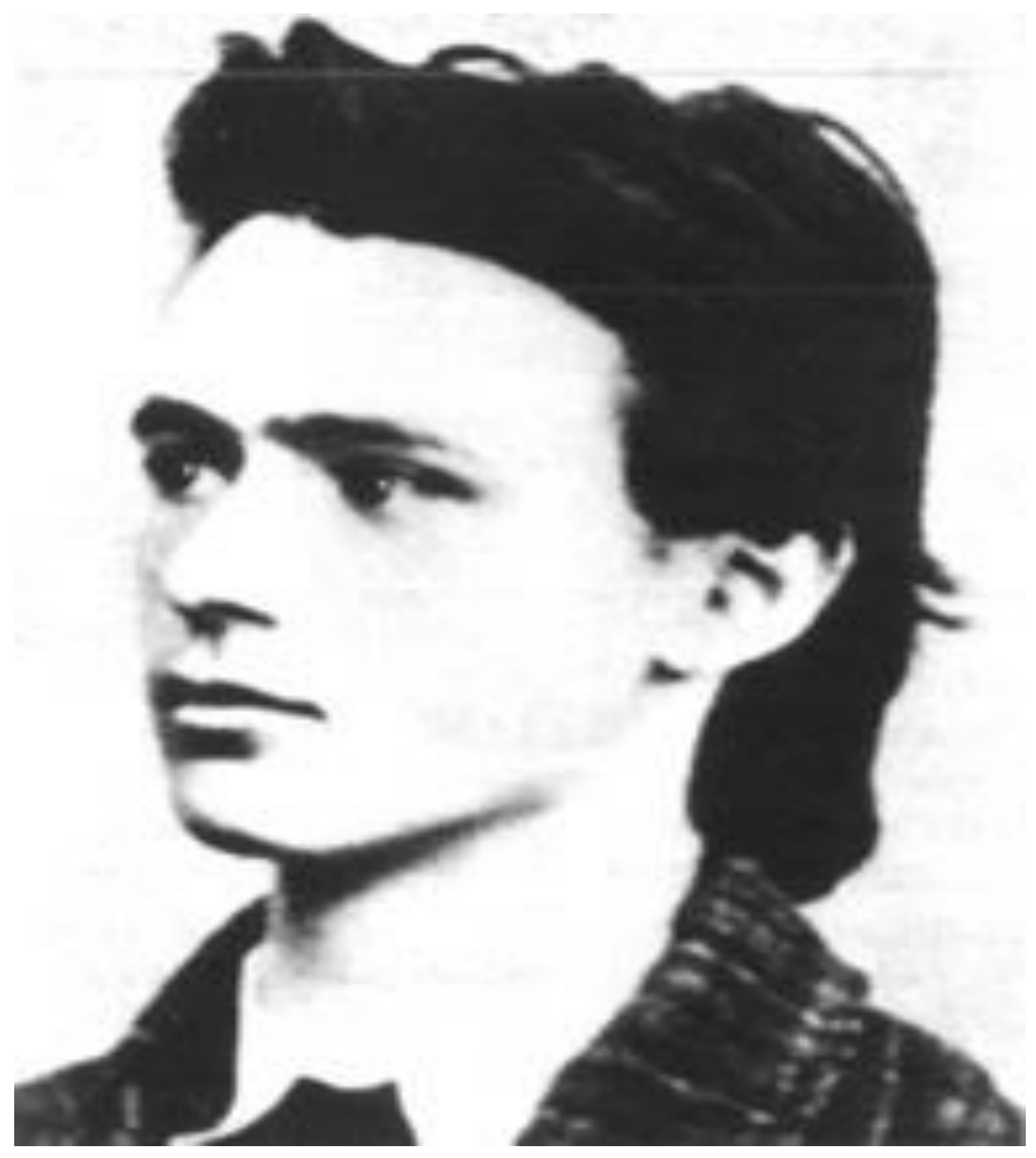

Fig. 1.1 - Rudolf Steiner (1861-1925), fotografia tirada em 1879. Disponível em <http://uncletaz.com/steinerphotos/stein13.html>. 
Metaphysik). Para que pudesse entender e ampliar seus conhecimentos sobre o "mundo espiritual", Steiner buscou as obras de outros pensadores da época de Kant, como Traugott $\mathrm{Krug}^{8}$ e a sua obra Transcendental Synthesis ("Síntese Transcedental"). Leu, também, Destiny of Man (“Destino do Homem”) de Fichte. Em seguida, leu Johann Friedrich Herbart ${ }^{9}$, cujas ideias se opunham às de Fichte, Schelling e Hegel (STEINER, 1985,51-53).

De acordo com Steiner, um dos professores que mais o marcou, nessa época, foi Karl Julius Schröer. Nas aulas de Schröer, Steiner leu A Literatura Alemã desde Goethe e Vida e obra de Schiller (Deutsche Literatur seit Goethe e Schillers Leben und Werke). Na época, Schröer havia publicado a primeira parte do Fausto de Goethe e estava ocupado escrevendo uma introdução para a segunda parte (STEINER, 1985:91). Em 1880, Steiner leu, pela primeira vez, o Fausto de Goethe, estimulado por este professor (HEMLEBEN, 1989:31).

Além de seu interesse por Goethe, Schröer tinha um interesse especial pelas peças de Natal que eram representadas todos os anos pelos camponeses alemães, emigrados para a Hungria, na região de Presburg. Ele resgatou as "Peças de Natal de Oberufer" numa publicação entitulada "Peças de Natal alemãs da Hungria" (HEMLEBEN, 1989:32) ${ }^{10}$.

Steiner também teve aulas com Robert Zimmerman e Franz Brentano ${ }^{11}$

\footnotetext{
${ }^{8}$ Escritor e filosofo alemão que procurou explicar o ego examinando a natureza de seus reflexos sobre os fatos da consciência. Ele propôs reconciliar o Realismo e o Idealismo.

${ }^{9}$ Steiner comenta ter lido Introduction to Philosophy and Psychology de Herbart, Mein Lebensgang, p. 46. Herbart (1776-1841), nascido na Alemanha, elaborou uma pedagogia que pretendia ser uma ciência da educação. Para ele, o processo educativo se baseava, em seus objetivos e meios, na ética e na psicologia, respectivamente.

${ }^{10}$ É interessante ressaltar neste ponto, que uma das atividades desenvolvidas até hoje nas Escolas Waldorf são as Peças Natalinas apresentadas pelos professores da escola e as Peças Teatrais, apresentadas pelos alunos do oitavo e do décimo-primeiro anos.

11 Steiner comentou que, as aulas de Brentano o estimularam tanto que ele leu quase todos os trabalhos do mesmo, em Mein Lebensgang, p.59. Franz Brentano era um padre católico, que lecionou psicologia para
} 
(Practical Philosophy). Nessa época leu Aesthetics as the Science of Form de Herbart e General Morphology de Haeckel (STEINER, 1985:55-59). Mais tarde, Steiner interessou-se pelas ideias de Charles Darwin (STEINER, 1985:66).

Durante dois anos, Steiner assistiu as aulas do professor Edmund Reitlinger sobre a teoria mecânica do calor, física para químicos e história da física. Reitlinger ensinava a história da física em duas partes: antes de Newton e depois de Newton. Reitlinger encorajou Steiner a ler quase todos os manuscritos de Julius Robert Mayers $^{12}$. Após as aulas sobre a teoria mecânica do calor, Steiner interessou-se pelas teorias cognitivas (STEINER, 1985:67-69).

Steiner trabalhou como preceptor para a família Specht sendo responsável por quatro meninos. Suas funções consistiam em orientar três deles nos estudos e cuidar do quarto, que tinha dificuldades físicas e mentais. Esse menino chamava-se Otto Specht e sofria de hidrocefalia. Steiner estudou fisiologia e psicologia para poder ajudá-lo a desenvolver-se física e mentalmente (STEINER, 1985:104). Com o tempo, o menino foi capaz de cursar o ginásio, sendo orientado por Steiner até o penúltimo grau. Segundo Steiner, após a conclusão do ginásio, Otto ingressou na faculdade de medicina, tornou-se médico, porém faleceu durante a Primeira Guerra Mundial. Esta experiência foi, nas palavras de Hemleben, uma missão que proporcionou a Steiner a possibilidade de dedicar-se concretamente aos problemas relacionados tanto à saúde como à doença (HEMLEBEN, 1989:39-40).

Durante este período, Steiner ocupou-se com a filosofia de Eduard von

Freud em seu curso de medicina. Com ele, Freud aprendeu lógica, teoria aristotélica e silogismo. Para Brentano, a psicologia deveria buscar leis exatas (Tito Lívio F. Vieira, O "Projeto para uma Psicologia cientifica” de Sigmund Freud, p. 5).

12 Julius Robert von Mayer (1814-1878), médico e físico alemão que em 1842 descreveu os processos químicos vitais atribuídos a oxidação como fonte primária de energia para toda criatura viva. 
Hartmann ${ }^{13}$, seus estudos sobre a teoria do conhecimento e seus trabalhos Phenomenology of Moral Consciousness e Religious Consciousness in Man in the Stages of its Evolution. Embora se opusesse ao pessimismo de Hartmann, Steiner considerava muito estimulante a forma como ele lidava com os problemas históricoculturais, pedagógicos e políticos (STEINER, 1985:108-110).

\subsection{CARREIRA E INTERESSES PROFISSIONAIS}

Em 1884, por sugestão de Schröer, Joseph Kürschner convidou Steiner para trabalhar com ele e um grupo de eruditos na edição das obras de Goethe para a coleção Literatura Nacional Alemã (Deutsche Nationalliteratur). Steiner ficou responsável pela edição das obras de Goethe, incluindo as que tratavam da zoologia e botânica, que haviam sido publicadas a partir do Metamorfose das Plantas (HEMLEBEN, 1989:41). Em sua autobiografia, Steiner fez diversos elogios a Goethe, comparando suas contribuições às de Galileu:

Eu descobri que a mecânica satisfaz completamente a necessidade por conhecimento, pois desenvolve conceitos de uma maneira racional na mente humana, os quais revelam-se reais na percepçãosensorial daquilo que é sem vida. Goethe foi para mim o criador de uma lei orgânica, que é aplicável àquilo que tem vida. Quando olho em retrospectiva para Galileu, na história da vida espiritual moderna, sou forçado a comentar como ele, ao expressar ideias sobre o inorgânico, deu à nova ciência natural sua forma atual. O que ele

13 Karl Roben Eduard von Hartmann (1842-1906), filósofo alemão que procurava conciliar duas correntes contrárias de pensamento, o racionalismo e o irracionalismo, por meio do papel central que atribui ao inconsciente. Escreveu vários trabalhos psicológicos e metafísicos, entre os quais vários estudos sobre os filósofos alemães Kant, Schopenhauer e Hegel. Também escreveu estudos sociais sobre religião, ética e política. 
apresentou para o inorgânico, Goethe lutou por conseguir para o orgânico. Goethe tornou-se para mim o Galileu do orgânico (STEINER, 1985:113) ${ }^{14}$.

Ao trabalhar a Introdução feita para o primeiro volume das obras científiconaturais de Goethe, Steiner criticou a visão materialista estabelecida pelo Darwinismo, defendendo a forma de pensar de Goehte (Steiner, 1985:110-117), que era um representante da Naturphilosophie ${ }^{15}$.

De acordo com Steiner, a partir da análise das características exteriores de uma determinada planta encontrada em Veneza, próximo ao mar, Goethe concluiu que a essência da planta não poderia ser encontrada nestas qualidades. Steiner afirmou que Darwin partiu de observações semelhantes às feitas por Goethe, quando manifestou suas dúvidas a respeito da constância das formas das espécies e gêneros. Mas os resultados aos quais chegaram os dois cientistas são completamente diferentes. Enquanto Darwin considerava que a essência do organismo se resume àquelas qualidades, tirando da mutabilidade a conclusão de não existir nada de constante na vida das plantas, Goethe foi mais longe, pois concluiu que estas qualidades não são constantes e a constância deve ser procurada em algo diferente que subjaz a esses aspectos exteriores que se transformam. Para Steiner, Goethe tinha como meta desvendar isso, enquanto Darwin visava pesquisar e expor as causas da mutabilidade em seus detalhes. $\mathrm{Na}$

\footnotetext{
14 "Ich fand, da $\beta$ die Mechanik das Erkenntnisbedürfnis aus dem Grunde befriedigt, weil sie auf eine rationelle Art im Menschengeiste Begriffe ausbildet, die sie dann in der Sinnes-Erfahrung des Leblosen verwirklicht findet. Goethe stand als der Begründer einer Organik vor mir, die in der gleichen Art sich zu dem Belebten verhält. Wenn ich in der Geschichte des neueren Geisteslebens auf Galilei sah, so mußte ich bemerken, wie er durch die Ausbildung von Begriffen über das Anorganische der neueren Naturwissenschaft ihre Gestalt gegeben hat. Was er für das Anorganische geleistet hat, das hat Goethe für das Organische angestrebt. Mir wurde Goethe zum Galilei der Organik.” [os grifos são do autor] em Rudolf Steiner, Mein Lebensgang, p. 113.

${ }^{15}$ Iremos comentar um pouco sobre este movimento no final deste capítulo.
} 
opinião de Steiner ambos os enfoques são necessários e complementam-se reciprocamente. Steiner concluiu que o Darwinismo preocupou-se com a aparência exterior dos organismos, sem considerar o que Goethe considerou, isto é, que em todo organismo a aparência exterior é impregnada por um princípio interior ${ }^{16}$ e que o todo atua em todos os seus órgãos (STEINER, 1980:20-27).

Ao analisar as ideias de Goethe, Steiner considerou necessário rever as teorias do conhecimento e, em 1886, publicou suas ideias no livro O Método Cognitivo de Goethe - Linhas Básicas para uma Teoria do Conhecimento na Cosmovisão de Goethe ${ }^{17}$. A publicação foi feita antes de serem publicados os outros volumes da coleção Literatura Nacional Alemã de Kürschner (1887, 1890 e ss.) (HEMLEBEN, 1989:42).

Nesse livro, Steiner propôs despojar o conhecimento humano do caráter meramente passivo que lhe é atribuído, e entendê-lo como uma atividade do "espírito" humano. Ele afirmou que a verdadeira essência da ciência é a ideia e não a matéria exterior percebida. Comparada à percepção, que é aceita passivamente, a ciência é um produto da atividade do "espírito" humano. Para mostrar isso, Steiner comparou a atividade de conhecer com a criatividade artística, que também é uma atividade humana produtiva, e comentou sobre a necessidade de esclarecer a

\footnotetext{
${ }^{16}$ Steiner cita a força vital como sendo a força geratriz das espécies no livro Teosofia, p. 34.

17 Título original: Grundlinien einer Erkenntnistheorie der Goetheschen Weltanschauung, traduzido para o inglês com o título Theory of cognition in Goethe's World Conception. Em Hemleben a tradução para o português aparece com o título Fundamentos para uma Gnosiologia da Cosmovisão Goethiana - com particular consideração a Schiller (1886). A tradução que utilizamos é de 2004. No penúltimo parágrafo (p. 13) aparece o termo "fundamento gnosiológico". O livro é composto por sete capítulos, intitulados da seguinte forma: Questões preliminares (1. Ponto de partida; 2. A ciência de Goethe segundo o método de Schiller; 3. A tarefa de nossa ciência); A experiência (1. Determinação do conceito de experiência; 2. Indicação sobre o conteúdo da experiência; 3. Retificação de uma acepção errônea da experiência total; 4. Apelo à experiência de cada leitor); O Pensar (1. O pensar como experiência superior na experiência; 2. Pensar e consciência; 3. A natureza íntima do pensar); A ciência (1. Pensar e percepção; 2. Intelecto e razão; 3. O processo cognitivo; 4. O fundamento das coisas e o conhecer); A cognição da natureza (1. A natureza inorgânica; 2. A natureza orgânica); As ciências humanas (1. Introdução: espírito e natureza; 2. A cognição psicológica; 3. A liberdade humana; 4. Otimismo e pessimismo); Conclusão (O conhecer e o criar artístico).
} 
correlação entre ambas. Conforme Steiner, para Goethe, a ciência é o conhecimento do geral, conhecimento abstrato; a arte, por outro lado, seria a ciência transformada em ação. Portanto, a ciência seria a razão e a arte seu mecanismo e, definida desta forma, a arte poderia ser chamada de ciência prática. Nas palavras de Steiner:

Nossa teoria do conhecimento despojou a cognição de seu caráter meramente passivo que em geral Ihe é atribuído, compreendendo-o como atividade do espírito humano. Habitualmente, acredita-se que o conteúdo da ciência seja recebido de fora; entende-se até mesmo que a objetividade da ciência possa ser mantida em grau tanto maior quanto mais o espírito se abstenha de qualquer adição própria ao material captado. Nossas explicações mostram que o verdadeiro conteúdo da ciência não é, em absoluto, a matéria exterior percebida, mas a ideia mentalmente apreendida, que nos introduz mais profundamente na engrenagem do mundo do que toda dissecação e observação do mundo exterior como mera experiência. A ideia é conteúdo da ciência. Com isso, diante da percepção obtida passivamente a ciência é um produto da atividade do espírito humano (...). A superação do sensorial pelo espírito é a meta da arte e da ciência. Esta supera o sensorial dissolvendo-o completamente em espírito; aquela, implantando-Ihe o espírito. A ciência olha através do sensorial para a ideia; a arte enxerga a ideia no sensorial. Para concluir nossas considerações segue-se um texto de Göethe, expressando essas verdades de modo abrangente ${ }^{18}$ : 'Penso que se poderia chamar a ciência de conhecimento do genérico, de saber obtido; a arte, ao contrário, seria ciência aplicada à ação; a ciência seria a razão e a arte seu mecanismo, e por isso também se poderia denominá-la ciência prática. Por fim, então, a ciência seria o teorema, e a arte, o problema'. (GOETHE, $1897^{19}$ apud STEINER, 2004:50).

\footnotetext{
18 [Os grifos são do autor].

19 "Goethes naturwisenchaftliche Schriften", vol. V: Matterialen zur Gerschichte der Farbenlenhre (Schluss). Entoptische Fatrbcn. Paralipomena zur Chromattik. Sprüche in Prosa. Nachträge (1897:535).
} 
É justamente na diferenciação entre a atividade de conhecer e a atividade artística que Steiner conceitua as bases da Pedagogia Waldorf que será apresentada no capítulo 2 desta tese.

Por intermédio de Schröer, Steiner conheceu a escritora e poetisa Marie Eugenie delle Grazie. Ele passou a frequentar a casa da poetiza onde eram feitas leituras de seus poemas. Steiner escreveu um artigo "Nature and our Ideas" (Die Natur und unsere Ideale), do qual existem algumas cópias, apesar de não ter sido publicado. Neste artigo, Steiner defendeu a correção das ideias de delle Grazie. Ele concordava com ela em que um ponto de vista que não oculte a hostilidade manifestada pela natureza contra os ideais humanos, não é mais do que um "otimismo superficial" que cega em si o abismo da existência. Por conta deste artigo, Schröer rompeu sua amizade com Steiner e com delle Grazie, dizendo que não poderia pensar de tal forma pessimista e que, se Steiner pensava desta forma, então, eles nunca haviam se entendido (STEINER, 1985:120-124).

$\mathrm{Na}$ casa de delle Grazie, Steiner conheceu os padres católicos Laurenz Müllner (1848-1911) e Wilhelm Newmann (padre da ordem de Cister da Santa Cruz), e outros teólogos. Além dessas pessoas, ele conheceu o filósofo Adolf Stöhr (18551921), a escritora Emilie Mataja (1855-1938), que escrevia sob o pseudônimo de Emil Marriot, o poeta e escritor Fritz Lemmermayer (1857-1932), o compositor Stross e o escultor Hans Brandstetter. Segundo Steiner, as tardes agradáveis de sábado, passadas na companhia de tais pessoas e o rompimento com Schröer originaram, posteriormente, o livro A Filosofia da Liberdade ${ }^{20}$, publicado em 1894 (STEINER,

\footnotetext{
20 Título original: Die Philosophie der Freiheit, traduzido para o inglês americano como The Philosophy of Freedom, para o inglês britânico como The Philosophy of Spiritual Activity e para o espanhol como La Filosofia de La Libertad. O livro é composto por três partes, apresentadas da seguinte forma: A ciência da liberdade (I. A ação humana consciente; II. O impulso fundamental para a ciência; III. O pensar a serviço da
} 
1985:124-130).

Nesse livro, Steiner criticou os pensadores que acreditam que a vontade do homem é determinada por circunstâncias externas (STEINER, 1979:15-18). Steiner concluiu que o indivíduo não está, na realidade, separado do mundo, mas faz parte deste, e sua conexão com a totalidade do cosmo encontra-se interrompida, não na realidade, mas só para nossa percepção. Ele afirmou que o conhecimento do real, frente à aparência da percepção, sempre constituiu a finalidade do pensar humano. O pensar abarca, ao mesmo tempo, o subjetivo e o objetivo, e nos comunica a realidade total na união que realiza entre a percepção e o conceito. Não é o conceito abstrato que contém a realidade, mas sim a observação pensante, que não considera por si sós nem o conceito nem a percepção, mas a união de ambos (STEINER, 1979:193-197). Para Steiner, no querer, a liberdade é praticada; no sentir, ela é experimentada; no pensar, ela é conhecida ${ }^{21}$. Este assunto será retratado nas seções 2 e 3 do capítulo 3 desta tese.

Em 1888, por um curto período, Steiner foi editor do jornal Deutsche Wochenschrift ("Revista Semanal Alemã") sobre a situação dos assuntos públicos do Estado na Áustria. Foi quando leu Karl Marx, Friedrich Engels, Rodbertus ${ }^{22}$ e outros escritores que tratavam da economia social (STEINER, 1985:146-149).

No dia 9 de novembro de 1888, Steiner proferiu uma palestra sobre Goethe na Sociedade Goethe de Viena ${ }^{23}$. Neste mesmo ano, viajou, pela primeira vez, para

compreensão do mundo; IV. O mundo considerado como percepção; V. O conhecimento do mundo; VI. A individualidade humana; VII. Existem limites para o conhecimento?); A realidade da liberdade (VIII. Os fatores da vida; IX. A ideia da liberdade; X. Filosofia da liberdade e monismo; XI. O objetivo da vida e do mundo (destino do homem); XII. A fantasia moral (moral e darwinismo); XIII. O valor da vida (otimismo e pessimismo); XIV. A individualidade e a espécie); As últimas questões (fala das consequiências do monismo).

21 "Im Wollen wird die Freiheit geübt; im Fühlen wird sie erlebt; im Denken wird sie erkannt." [os grifos são do autor] - Rudolf Steiner, Mein Lebensgang, p. 178.

22 Karl Johann Rodbertus (1805-1875), economista e socialista conservador alemão.

23 "Goethe als Vater einer neuen Ästhetik" traduzida para o Português como "Goethe como pai de uma nova 
a Alemanha. Ele fora convidado pela diretoria do Instituto Goethe, em Weimar, a participar da edição de obras conhecidas e de manuscritos não publicados de Goethe. Alguns anos antes, o neto de Goethe, Walther von Goethe, morrera deixando para a grã-duquesa Sophie da Saxonia os manuscritos de seu avô (STEINER, 1985:150). Steiner ficou responsável pela edição das obras científiconaturais, em conexão com a grande "Edição Sophia" (HEMLEBEN, 1989:45).

Além da emoção de poder frequentar os lugares onde nasceram os pensamentos de Goethe, Steiner mencionou que identificara nos manuscritos não publicados de Goethe uma importante contribuição que possibilitaria uma maior compreensão das ideias do autor sobre o conhecimento (STEINER, 1985:150-153).

Na volta de Weimar, Steiner decidiu visitar o filósofo Eduard von Hartmann, em Berlim. Eles não se conheciam pessoalmente, mas se correspondiam há muitos anos discutindo sobre problemas filosóficos (STEINER, 1985:154).

Ao retornar de Weimar, Steiner passou a frequentar a casa de Marie Lang juntamente com um grupo de arquitetos e literatos. Foi lá que conheceu Rosa Mayreder ${ }^{24}$ e seu esposo Karl Mayreder (STEINER, 1985:158).

No outono de 1890, Steiner transferiu-se definitivamente para Weimar, onde permaneceu por quase sete anos, trabalhando no Instituto Goethe-Schiller, que se encontrava sob o patrocínio da Grã-Duquesa Sophia ${ }^{25}$. Este período é descrito por Steiner, como um período de solidão, embora convivesse com pessoas eminentes estética” em Hemlenben, Rudolf Steiner, p. 162.

${ }^{24}$ Rosa Mayreder (1858-1938) era escritora, pintora, música e "feminista". Seu marido, Karl era arquiteto. Steiner atribuiu grande importância às conversas que manteve com Rosa antes da publicação do seu livro Filosofia da Liberdade. Após a mudança de Steiner para Weimar, os dois mantiveram uma extensiva correspondência.

25 É relatado no volume XII do Anuário de Goethe: “Aos colaboradores permanentes juntou-se, no outono de 1890, Rudolf Steiner, de Viena. Foi-lhe atribuído todo o campo da Morfologia (com exceção da parte osteológica), cinco ou talvez seis tomos da segunda seção, aos quais aflui material altamente importante do espólio manuscrito" comenta Hemlenben, Rudolf Steiner, p. 47. Também citado por Rudolf Steiner em Mein Lebensgang, pp. 196-197. 
de seu tempo, como os historiadores Heinrich v. Treitschke (1834-1896) e Hermann

Grimm (1828-1901); Loeper (amigo e depois administrador das obras de Goethe); Erich Schmidt (responsável pela direção dos arquivos de Goethe), Ernst Haeckel e Hermann Helmholtz ${ }^{26}$, dentre outros (HEMLEBEN, 1989:50) ${ }^{27}$.

Em 1891, Steiner concluiu o doutorado em Filosofia com a tese "A questão fundamental da gnosiologia, com especial consideração à doutrina científica de Fichte" orientado pelo professor Heinrich v. $\operatorname{Stein}^{28}$ da Universidade de Rostock. A tese foi publicada em 1892 e traduzida para o inglês com o título Truth and Knowledge"29.

Nesta obra, Steiner criticou a ideia de que só há conhecimento quando a experiência oferece conteúdos à sensibilidade e ao entendimento. Ele refutou a ideia de que a razão, separada da sensibilidade e do entendimento, não conhece coisa alguma. Ele afirmou que seu objetivo não era mostrar o que nossa faculdade de conhecer não pode fazer, mas sim, mostrar o que ela é realmente capaz de executar. No livro, também fez uma crítica aos que buscam os princípios primordiais das coisas sem antes assentarem as bases para investigar a natureza do conhecimento em si. Sua conclusão é que a verdade não é uma reflexão ideal de

${ }^{26}$ Hermann Helmholtz (1821-1894) nascido na Alemanha, graduou-se no Instituto Médico de Berlim em 1843. Dedicou boa parte de seus estudos tentando mostrar que a força dos músculos provinham de princípios químicos e físicos e não a partir de uma força vital.

${ }^{27}$ Hemleben transcreve um trecho de uma carta, de 20 de outubro de 1890, de Steiner para Rosa Mayereder: "Aqui me acho sozinho. Não há ninguém que, mesmo de longe, compreenda aquilo que me move e que sustenta meu espírito". Há também um trecho de uma carta da mesma época para o amigo Friedrich Eckstein: "O senhor dificilmente formará uma ideia de quão só e incompreendido me sinto aqui".

${ }^{28}$ Steiner decidiu submeter sua tese ao filósofo Heirich von Stein após a leitura de sua obra Sieben Bücher Platonismus (traduzida para o Português por Hemlenben como Sete Livros de Platonismo, Rudolf Steiner, p. 51) - de acordo com Rudolf Steiner em Mein Lebensgang, p.198.

${ }^{29}$ Rudolf Steiner, Verdade e Ciência - Prólogo para uma "Filosofia da Liberdade”, 1892. O livro foi dedicado ao Dr. Eduard von Hartmann - ver Hemleben, Rudolf Steiner, p. 52. Trabalhamos com a edição de 1985 (Verdade e Ciência - Prelúdio a uma "Filosofia da Liberdade"). O livro é composto por um Prefácio à edição alemã, Introdução e oito capítulos, distribuídos da seguinte forma: I. Observações preliminares; II. A pergunta gnosiológica fundamental de Kant; III. A teoria do conhecimento depois de Kant; IV. Os pontos de partida da teoria do conhecimento; V. Conhecimento e realidade; VI. A teoria do conhecimento isenta de premissas e a "doutrina da ciência" de Fichte; VII. Observação gnosiológica final; VIII. Consideração final prática. 
algo real, mas é "o produto do espírito humano", criada por uma atividade que é livre. Este produto não existiria em nenhum lugar se não o tivéssemos criado. 0 objeto do conhecimento não é repetir na forma conceitual algo que já existe, mas criar uma esfera completamente nova, a qual quando combinada ao mundo dado aos nossos sentidos constitui a realidade completa (STEINER, Verdade e Ciência, 1985).

Portanto, a atividade mais elevada do homem, sua criatividade espiritual, é uma parte orgânica do processo do mundo universal, que não deveria ser considerado uma totalidade fechada, completa. O homem não é um espectador em relação à evolução, meramente repetindo em fotografias mentais eventos cósmicos acontecendo sem sua participação. Ele é o co-criador ativo do processo do mundo, e a percepção é a mais perfeita ligação do organismo com o universo. Steiner afirmou que este insight tem a mais significante consequência para as leis que subjazem nossas ações, que são nossos ideais morais. Estes, também, não devem ser considerados como cópias de alguma coisa que existe fora de nós, mas como estando exclusivamente presentes dentro de nós (STEINER, Verdade e Ciência, 1985).

No período em que trabalhou no Instituto Goethe-Schiller, Steiner conheceu Elisabeth Forster-Nietzsche, irmã do filósofo Friedrich Nietzsche. Ela desejava obter informações sobre a organização do arquivo Goethe-Schiller para poder criar o arquivo do irmão, que na época encontrava-se enfermo ${ }^{30}$. Steiner também tornou-se amigo do editor das obras de Nietzsche, Fritz Koegel (HEMLEBEN, 1989:56) (STEINER, 1985:252).

\footnotetext{
${ }^{30}$ Nietzsche apresentou uma "paralisia progressiva", provavelmente de origem sifilítica. A moléstia progrediu lentamente até a apatia e a agonia. Faleceu em Weimar, a 25 de agosto de 1900 (Olgária Chaim Ferez, Os Pensdadores, p. 9).
} 
A convite de Elizabeth Forster-Nietzsche, Steiner passou várias semanas organizando a Biblioteca de Nietzsche, em Naumburg. Ele frequentou o Arquivo Nietzsche em Naumburg e Weimar (STEINER, 1985:256,261-265) ${ }^{31}$. A partir dos estudos feitos nos Arquivos de Nietzsche, Steiner publicou, em 1895, o livro Friedrich Nietzsche, um lutador contra seu tempo 32 (STEINER, 1985:251).

Em 1897, Steiner publicou o livro A Cosmovisão de Goethe ${ }^{33}$ como resposta às oposições existentes entre as ideias de Goethe e Nietzsche ${ }^{34}$ (STEINER, 1985:259).

De acordo com Johannes Hemleben, as publicações de Steiner, durante os aproximadamente sete anos de sua estadia em Weimar, abrangem em torno de noventa e cinco títulos: os sete volumes da "Edição Sophia", os volumes na Literatura Nacional de Kürschner, a dissertação de doutorado que depois foi transformada em Verdade e Ciência, o livro sobre Nietzsche e sua obra filosófica básica A Filosofia da Liberdade (HEMLEBEN, 1989:63-64). (Ver figura 1.2).

Durante a maior parte de sua estada em Weimar, Steiner morou como locatário na casa de Anna Eunike (1853 - 1911), viúva do capitão de reserva Eugen Friedrich Eunike e mãe de cinco filhos, quatro meninas e um rapaz. Steiner e Anna

\footnotetext{
${ }^{31}$ Steiner comentou que seu primeiro contato com as obras de Nietzsche foi em 1889. Em sua autobiografia (Mein Lebensgang, p. 185) ele cita a obra Para Além de Bem e Mal (titulo original no alemão Jenseits von Gut und Böse, traduzido para o inglês Beyond Good and Evil) como tendo sido a primeira obra lida do autor. No período em que frequentou os Arquivos de Nietzsche, Steiner leu ainda Willen zur Macht, eine Umwertung aller Werte (The Will to Power, a Translation of all Values), Eugen Dühring's Kursus der Philosophie als streng wissenschaftlicher Weltanschauung und Lebensgestaltung (The Course of Philosophy as a Strictly Scientific World-Conception and Shaping of Life), Zarathustra (Assim Falou Zaratustra) e, a obra, que Steiner considerava sua obra-prima Umwertung aller Werte (também traduzida como The Will to Power, a Translation of all Values) - ver Rudolf Steiner, Mein Lebensgang, pp. 256, 261-265.

${ }^{32}$ Título original em alemão Nietzsche, ein Kämpfer gegen seine Zeit, traduzido para o inglês Nietzsche as the Adversary of His Age.

${ }^{33}$ Título original no alemão Goethes Weltanschauung, traduzido para o inglês Goethe's World-Conception.

${ }^{34}$ Steiner comentou que Goethe encontrava o espírito na realidade da vida, ao passo que Nietzsche perdera o mito-espírito no sonho da natureza em que ele viveu - "Goethe fand den Geist in der Naturwirklichkeit; Nietzsche verlor den Geist-Mythos in dem Naturtraum, in dem er lebte.” [os grifos são do autor].
} 


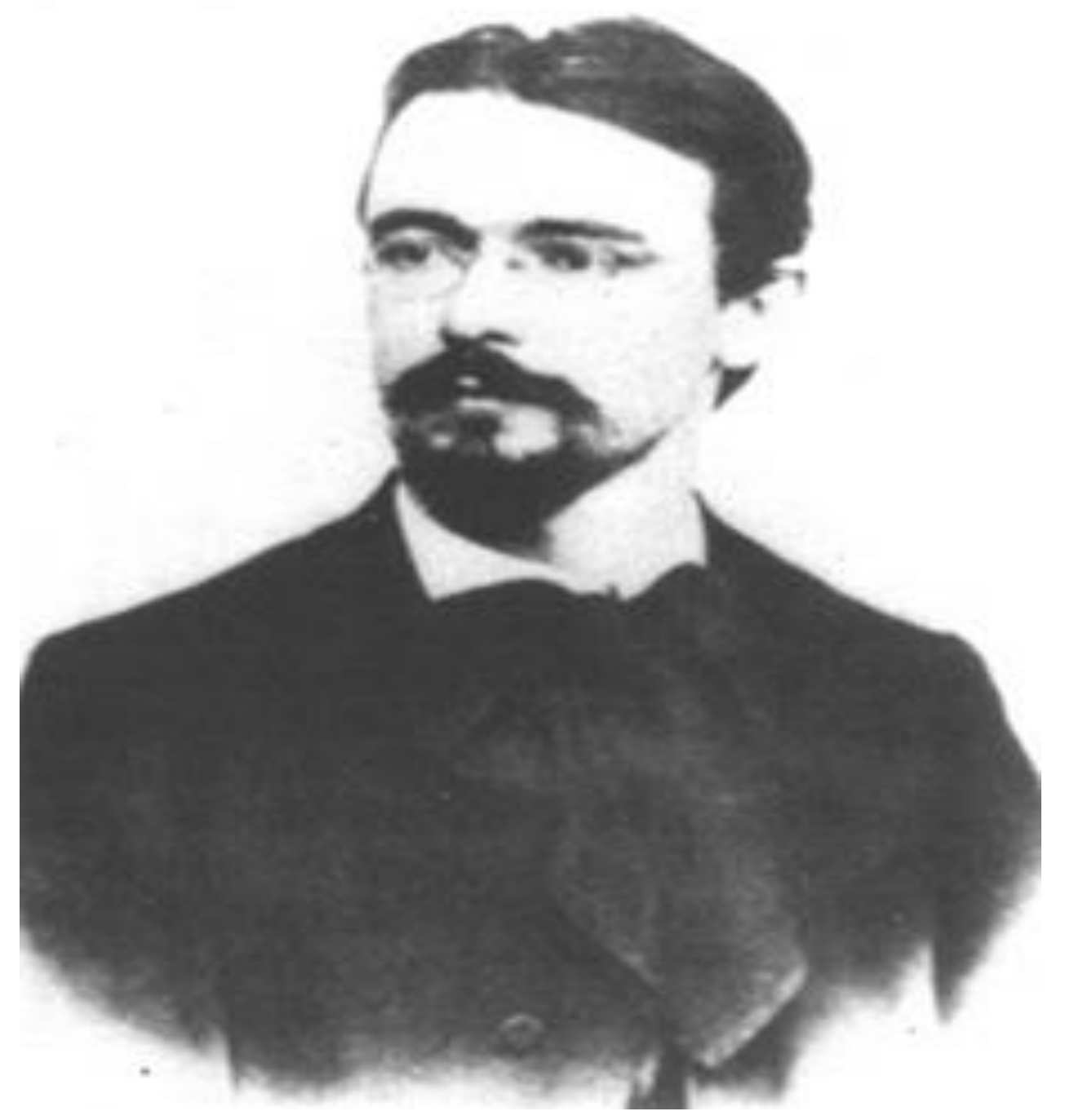

Fig. 1.2 - Rudolf Steiner (1861-1925), fotografia de 1896 logo após a publicação da obra "A Filosofia da Liberdade". Disponível em <http://uncletaz.com/steinerphotos/steinmar.html>. 
tornaram-se amigos. Na casa de Anna, Steiner recebia os frequentadores mais jovens das reuniões da Sociedade de Goethe, vindos de Berlim. Entre eles estava Otto Erich Hartleben (1864-1905). Mais tarde, porém, antes de Steiner, Anna Eunike mudou-se para Berlim. E, em 31 de outubro de 1899, Steiner e Anna se casaram (HEMLEBEN, 1989:55).

Steiner mudou-se para Berlim em 1897, com trinta e seis anos. Lá, foi professor até 1905, na escola de formação de trabalhadores fundada por Wilhelm Liebknecht. Em concordância com a diretoria da escola, Steiner optou por ensinar aos trabalhadores a História a partir de seu ponto de vista, isto é, a partir de sua opinião sobre o curso de evolução da humanidade, e não segundo o Marxismo, que era o estilo comum nos círculos socialdemocratas. Os tópicos tratados por ele abrangeram desde a história da Idade Média, da Revolução Francesa, da Idade Moderna, até a apresentação da "Evolução do Universo e a Vida Social dos Animais" e da "Anatomia do Ser Humano" (HEMLEBEN, 1989:76-77).

Logo no início de sua vida em Berlim, Steiner interagiu com Otto Erich Hartleben, co-editor do Magazine de Literatura que circulava em Berlim desde 1832 (após a morte de Goethe). Esse Magazine, com o passar do tempo, tornara-se um instrumento da "Sociedade Literária Livre", a oponente revolucionária da tradicional "Sociedade Literária". Desta forma, Steiner passou a conviver com a vanguarda dos boêmios em Berlim. Entre as pessoas deste círculo estavam o poeta Ludwig Jacobowski ${ }^{35}$ e o escritor John Henry Mackay (que foi padrinho de casamento de Steiner). Paralelamente a este círculo, Steiner frequentava outro círculo de pessoas completamente diferente; eram os fundadores da "Escola Superior Livre", Bruno

\footnotetext{
${ }^{35}$ Fundador da Sociedade "Die Kommenden" ("The Coming Ones") formada por escritores, artistas, cientistas e pessoas interessadas em arte - conforme Rudolf Steiner, Mein Lebensgang, pp. 382-384.
} 
Wille e Wilhelm Bölsche (amigos de Haeckel), o teólogo liberal e colaborador Theodor Kappstein e membros da "Associação Giordano Bruno"36, que na época lutavam pelo "monismo"37.

Além das atividades mencionadas acima, nessa mesma época, Steiner foi eleito diretor da Sociedade Dramática Livre, companhia de teatro associada ao grupo do Magazine de Literatura. Ele participava dos ensaios na companhia de Otto Erich Hartleben. A primeira peça produzida por ele foi "L'Intruse" de Maurice Maeterlinck (STEINER, 1985:353-355).

O ano de 1900 marcou o início das atividades de Rudolf Steiner como palestrante. Ele proferiu palestras e participou de cerimônias em memória de Nietzsche na "Associação para o incremento da arte". Em 17 de junho de 1900, para um público de sete mil tipógrafos reunidos em um grande circo em Berlim, Steiner proferiu o discurso "O feito de Guttenberg como marco da revolução cultural", discurso solene para o quinquagésimo aniversário de Guttenberg (HEMLEBEN, 1989:77).

Em 1901, Steiner proferiu 24 palestras sobre "De Buda a Cristo” no círculo dos "Kommenden" (HEMLEBEN, 1989:164). Nessas palestras, Steiner procurou conceituar uma ciência espiritual a partir da comparação das influências orientais do Budismo na cultura ocidental cristã. Comparou Buda ao mistério de Gólgota (ou ressurreição de Cristo) e discutiu a evolução da humanidade, defendendo a ideia da reencarnação (STEINER, 1985:395). Não podemos esquecer de que o

\footnotetext{
36 Steiner comentou que a Associação Giordano Bruno reunia pessoas que simpatizavam com a filosofia espiritual-monista. Eles não acreditavam na existência de dois princípios - matéria e espírito - acreditavam que o espírito era o princípio único de toda a existência, Mein Lebensgang, pp. 385-387.

37 Termo moderno usado para indicar a concepção filosófica que não só deduz toda a realidade de um único princípio, mas considera o ser da realidade idêntico àquele princípio. [os grifos são do autor] em G. Reale, História da Filosofia Antiga, vol V, pp. 174-175.
} 
espiritualismo, nessa época, estava relacionado à ideia de progresso também presente nas questões relacionadas à ciência ${ }^{38}$. De acordo com Hemleben, "apesar de toda - por momentos radical - refutação das formas e dogmas históricos das igrejas", Steiner "via em Jesus Cristo e no 'acontecimento de Gólgota' o evento central da História da Terra e da Humanidade" (HEMLEBEN, 1989:82).

Neste mesmo ano, a convite do Conde e da Condessa de Brockdorff, líderes de uma filial da Sociedade Teosófica, Steiner proferiu 25 palestras sobre "Concepções do mundo e da vida no século XIX", dedicadas a Erns Haeckel e, mais tarde, sobre o "Cristianismo como fato místico"39 na "Biblioteca Teosófica" de Berlim (HEMLEBEN, 1989:164). Essas palestras tinham, segundo Steiner, como objetivo, mostrar a evolução dos mistérios antigos até o mistério de Gólgota, não apenas como forças históricas terrestres, mas também como influências "espirituais" supramundanas. Steiner desejava mostrar que nas imagens dos cultos dos mistérios antigos foi dado o evento cósmico, que foi então efetuado mistério de Gólgota como fatos transferidos do cosmos à terra do plano histórico (STEINER, 1985:395).

Antes de prosseguirmos, julgamos procedente esclarecer, de forma breve, o que era a Sociedade Teosófica. Essa Sociedade foi fundada para promover os ensinamentos antigos de Teosofia, ou sabedoria relacionada ao divino, que era a base de outros movimentos do passado, como o neoplatonismo, o gnosticismo ou gnose, e as escolas de Mistério do mundo clássico. Atribui-se à Helena Petrovna Blavatsky (1831-1891) a fundação desta Sociedade. A Sociedade Teosófica teve três

\footnotetext{
${ }^{38}$ Ver a respeito em Juliana H. M. Ferreira, Estudando o Invisível: William Crookes e a nova Força, pp. 22-23; Robert Nisbet, A Ideia de Progresso, p. 181.

${ }^{39}$ Estas palestras foram publicadas, inicialmente, em dois volumes. Steiner comentou que na $2^{\mathrm{a}}$. edição incluiu uma pesquisa da evolução das concepções de mundo do período grego até o século XIX. Em 1914, as palestras foram publicadas no livro intitulado Riddles of Philosophy - em Rudolf Steiner, Mein Lebensgang, pp. 396, 400-401.
} 
objetivos principais de 1881 a 1890. O primeiro objetivo era formar o núcleo de uma Fraternidade Universal da Humanidade sem distinção de raça, credo, sexo, casta ou cor. Seu segundo objetivo era promover o estudo da literatura ariana e outras religiões, filosofias e ciências orientais e demonstrar sua importância para a Humanidade. O terceiro objetivo, buscado por uma parte dos membros da Sociedade, era investigar as Leis Inexplicáveis da Natureza e os poderes psíquicos latentes no homem (LETZERICH, A Evolução dos Objetivos da Sociedade Teosófica, 2005).

A Sociedade encorajava o estudo de religiões, ciências e filosofias, ancestrais e modernas, para auxiliar a promover um entendimento entre as pessoas e o reconhecimento dessa unidade de vida. Estudava e discutia temas ligados à espiritualidade (ideias de reencarnação, carma, existência de civilizações extremamente desenvolvidas etc.) e divulgava no mundo ocidental, noções oriundas da teosofia oriental.

Annie Besant, considerada a continuadora da obra de Blavatsky, ficou à frente da seção europeia da Sociedade Teosófica e William Q. Judge (1851 - 1896) da seção norte-americana (SCHOEREDER, G. Blavatsky e a Sociedade Teosófica, 2005).

Em julho de 1902, Steiner se tornou membro da Sociedade Teosófica e participou, juntamente com Marie von Sivers ${ }^{40}$, da $13^{a}$. assembleia anual da Seção Europeia da Sociedade Teosófica, em Londres. Em outubro do mesmo ano, na presença de Annie Besant, Steiner fundou em Berlim a "Seção Alemã da Sociedade Teosófica". Marie von Sivers ficou responsável pela direção e Steiner foi escolhido

\footnotetext{
${ }^{40}$ Marie von Sievers, artista formada em arte e recitação, conheceu Steiner em uma de suas palestras - ver Hemlenben, Rudolf Steiner, p.81.
} 
para Secretário-Geral da mesma (STEINER, 1985:396-397). A convite de Steiner, Annie Besant proferiu diversas palestras em várias cidades da Alemanha, como Hamburgo, Berlim, Weimar, Munique, Stuttgart e Colônia (STEINER, 1985:422). (Ver figura 1.3).

Até abril de 1903, Steiner proferiu um total de 27 conferências sobre o tema: "De Zaratustra a Nietzsche - História da evolução da humanidade com base nas cosmovisões desde os tempos primordiais orientais até a atualidade, ou Antroposofia" no círculo de "Kommenden". Foi aí que utilizou, pela primeira vez, a palavra "Antroposofia" 41 que mais tarde denominaria o que ele chamou de "ciência espiritual" (HEMLEBEN, 1989:80).

Paralelamente à atividade desenvolvida por Steiner na Sociedade Teosófica, Steiner fundou, juntamente com Marie von Sivers, a revista mensal Luzifer (Lúcifer) (STEINER, 1985:422-423). De acordo com Steiner, nessa época, este nome significava simplesmente "portador de luz" e não a potência "espiritual" que mais tarde ele denominou Lúcifer, o oposto de Árimã (conceito posteriormente introduzido na Antroposofia). Steiner escrevia a maioria dos artigos e Marie von Sivers o ajudava com a correspondência. No início, eram eles próprios que dobravam as folhas, colocavam-nas em envelopes, selavam-nos e os levavam para o correio. O número de assinantes cresceu rapidamente, o que chamou a atenção de Herr Rappaport, responsável pela publicação do jornal Gnosis em Berlim. Foi assim que as duas publicações se uniram em uma única que passou a se chamar Luzifer Gnosis (HEMLEBEN, 1989:87) (STEINER, 1985:421-423).

\footnotetext{
${ }^{41}$ Hemlenben explica que, Antroposofia como palavra e denominação já é encontrada em Immanuel Hermann Fichte, o filho de Johann Gottlieb Fichte. Também o professor universitário de Rudolf Steiner, Robert Zimmermann, teólogo sistemático do Belo, escolherá a palavra "Antroposofia" como título de sua obra fundamental sobre Estética.
} 


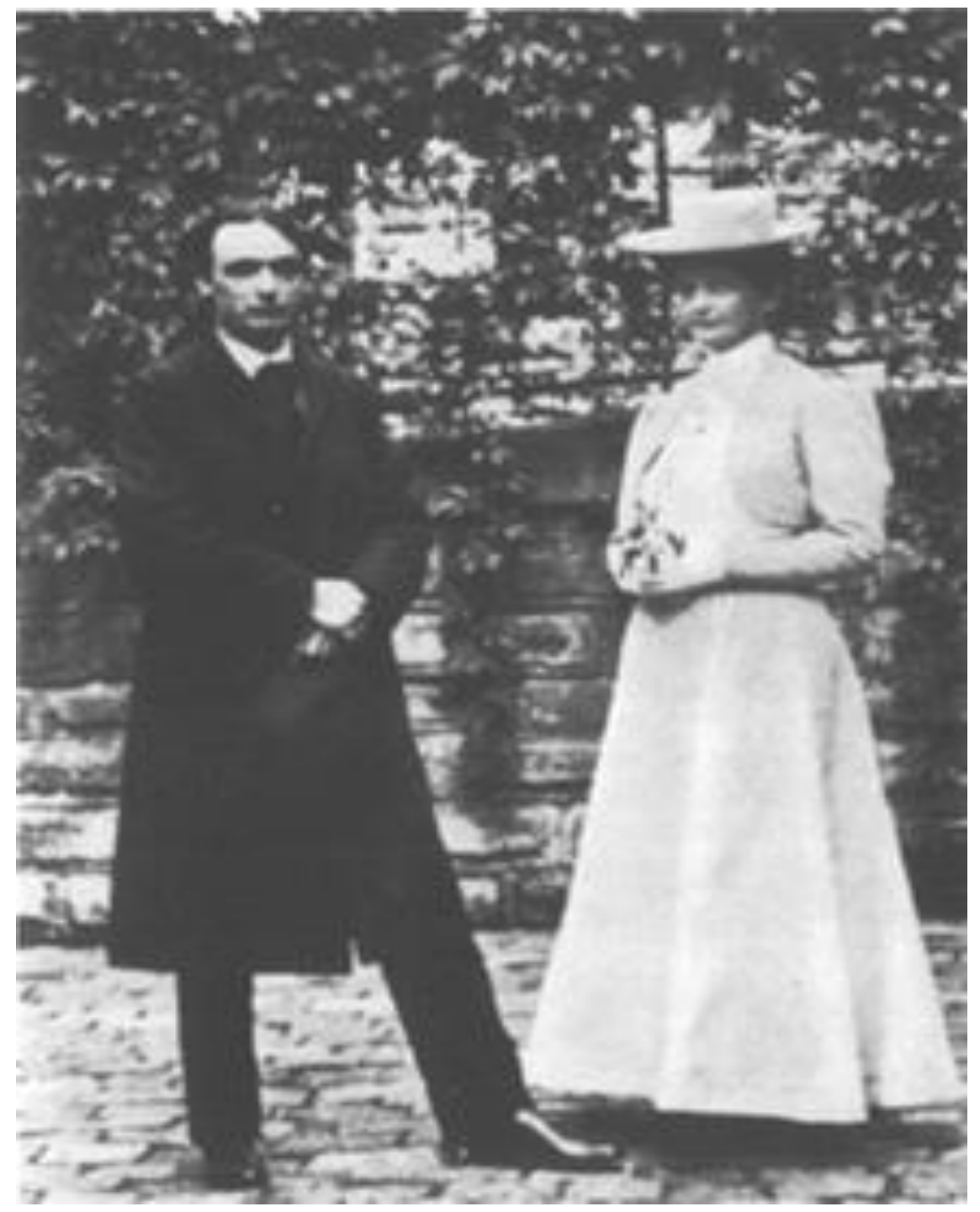

Fig. 1.3 - Rudolf Steiner (1861-1925) e Marie von Sivers. Foto de 1908. Disponível em <http:/uncletaz.com/steinerphotos/steinmar.html>. 
Embora o número de assinantes continuasse a crescer, Steiner foi obrigado a interromper a produção do Luzifer Gnosis em 1908 devido ao excesso de trabalho na época, sobretudo à atividade discursiva em contínua expansão (HEMLEBEN, 1989:87).

Ao longo de sua vida, Steiner escreveu cerca de 40 livros e proferiu mais de 6.000 palestras (BARFIELD, Rudolf Steiner - uma apresentação, 2005). Inicialmente, atuando publicamente no âmbito da Teosofia em Weimar, Colônia, Hamburgo, Stuttgart, Lugano, Nuremberg, Heidelberg, Dusseldorf. Em 22 de junho de 1904, participou no Congresso Teosófico em Amsterdã com a palestra sobre "Matemática e Ocultismo". Em 1905, palestras em Berlim e em metrópoles alemãs sobre o Evangelho segundo João, entre outros. Em 1906, primeiro grande ciclo de conferências em Paris (dezoito conferências), Leipzig (catorze conferências), Stuttgart, Frankfurt e Munique. Em 1907 apresentou conferências em Munique, Kassel, Hannover e Basiléia. Em 1908, primeira viagem à Escandinávia: Lund, Malmoe, Estocolmo, Upsala, Kristiania (Oslo), Goetborg e Copenhague. Neste mesmo ano, Steiner viajou novamente para a Escandinávia e proferiu quinze palestras sobre o Evangelho segundo João, em Kristiania, além dos ciclos em Stuttgart e Leipzig. Em 1909, proferiu sete palestras em Roma, ciclos em Dusseldorf, Kristiania, Budapeste (dez conferências), Kassel e Munique apontando para "A Volta do Cristo". Também em 1909, na Basiléia, "O Evangelho segundo Lucas"42.

Os ciclos de conferência sobre os evangelhos marcam o início do desagrado de Steiner em relação aos membros da Sociedade Teosófica. Alguns membros da Sociedade haviam abraçado uma corrente fortemente orientalista ao declarar que

\footnotetext{
${ }^{42}$ Conforme quadro cronológico em Hemlenben, Rudolf Steiner, pp. 164-165.
} 
um jovem hindu, Krishnamurti, era a reencarnação de Cristo. Steiner opôs-se totalmente a essa ideia (mais tarde negada pelo próprio Krishnamurti).

O rompimento definitivo só ocorreu em 1913, período considerado como a segunda fase do desenvolvimento da Antroposofia. Vários membros da Sociedade Teosófica seguiram-no e foram os responsáveis pela formação da primeira Sociedade Antroposófica.

\subsection{O MOVIMENTO ANTROPOSÓFICO}

O período compreendido entre 1902 e 1909, é descrito por Hemleben e outros autores, como a primeira fase de desenvolvimento da Antroposofia que, além das palestras e conferências, abrange também duas importantes publicações que a difundiam. A primeira delas é o livro Teosofia ${ }^{43}$ publicado em 1904; a segunda, é o livro Como se Adquire Conhecimentos dos Mundos Superiores? (HEMLEBEN, 1989:90-95).

No livro Teosofia, Steiner defendeu a ideia de que a relação do homem com as coisas do mundo ocorre em três domínios, ou como ele mesmo diz, de maneira tripla: as coisas do mundo, as quais ele percebe através dos sentidos; as impressões que as coisas do mundo causam nele (agrado-desagrado, cobiça-nojo, simpatia-antipatia etc.); e os conhecimentos que ele alcança sobre as coisas do mundo. A terceira maneira é considerada por Steiner como uma meta à qual o

\footnotetext{
${ }^{43}$ Dedicado à Giordano Bruno - ver Hemleben, Rudolf Steiner, p. 90. Este livro é composto por cinco partes: Introdução, A natureza do Homem (I. A natureza corpórea do homem; II. A natureza anímica do homem; III. A natureza espiritual do homem; IV. Corpo, alma e espírito), Reencarnação do espírito e destino (Os três mundos; I. O mundo anímico; II. A alma no mundo das almas após a morte; III. O mundo espiritual; IV. O espírito no mundo dos espíritos após a morte; V. O mundo físico e sua ligação com os mundos das almas e dos espíritos; VI. Das formas-pensamentos e da aura humana), A senda do conhecimento.
} 
homem deve aspirar incessantemente. E é com essa explicação da maneira tripla que Steiner definiu o homem e sua relação com o mundo exterior, consigo mesmo e com o mundo suprassensível:

Assim, o homem se associa continuamente às coisas do mundo dessa tríplice maneira. [...] Dela decorre que o homem tem três faces em sua natureza. É isso, e nenhuma outra coisa, que por ora indicaremos com as três palavras corpo, alma e espírito. Quem associar essas três palavras a quaisquer opiniões preconcebidas, ou mesmo hipóteses, fatalmente entenderá mal o que será exposto em seguida. Por corpo entende-se elemento pelo qual as coisas em redor do homem se apresentam a ele - como, no exemplo acima, as flores do prado. Por alma deve-se entender o elemento pelo qual o homem associa as coisas ao seu próprio existir, sentindo nelas agrado e desagrado, prazer e desprazer, alegria e dor. Por espírito entende-se o que se revela nele quando, segundo a expressão de Goethe, ele contempla as coisas "como se fosse um ente divino". É nesse sentido que o homem consiste em corpo, alma e espírito. [...] O homem é, assim, cidadão de três mundos. Por meio de seu corpo, pertence ao mundo que ele percebe com esse mesmo corpo; por meio de sua alma, edifica para si seu próprio mundo; por meio de seu espírito se lhe manifesta um mundo elevado acima dos outros dois (STEINER, 2004:27-29).

Nesse livro, além de definir o homem e suas três partes, Steiner definiu, também, o mundo e suas três partes: o mundo anímico, o mundo espiritual e o mundo físico (STEINER, 2004:71-116). Muitas das ideias contidas nesse livro serão exploradas ao longo dos próximos capítulos desta tese.

No livro Wie erkennt man Erkenntnisse der höheren Welten? ("O 
Conhecimento dos Mundos Superiores?") ${ }^{44}$, Steiner explicou detalhadamente os exercícios e qualidades morais que devem ser cultivados para trilhar o caminho da experiência consciente das realidades suprassensíveis ou, dito de outra forma, o caminho antroposófico do conhecimento. Seu argumento era que as faculdades que estão adormecidas na consciência humana deveriam ser despertadas, e que isto levaria o homem a uma sabedoria vivificante.

O período compreendido entre 1910 e 1916 é descrito por Hemleben como a segunda fase do desenvolvimento da Antroposofia. Esta fase marca o envolvimento de Steiner com a arte por meio de representações de peças dramáticas. Esse envolvimento manifestou-se já em 1907, por ocasião do 4ํ․ Congresso Anual da Federação das Seções Europeias da Sociedade Teosófica, em Munique. Steiner incluiu uma apresentação artística ao programa: "O Drama Sacro de Elêsius" de Édouard Schuré (1841-1929) ${ }^{45}$. Em 1909, foi apresentado em Munique o drama Os Filhos de Lúcifer de Schuré. Após a reprise deste drama, no dia 14 de agosto de 1910, foi apresentado, no dia seguinte, o primeiro drama de mistério escrito por Rudolf Steiner: O Portal da Iniciação. Steiner escreveu mais quatro dramas: $A$ Provação da Alma (apresentado em 17 de agosto de 1911), O Guardião do Limiar (24 de agosto de 1912), O Despertar das Almas (23 de agosto de 1913) e, o quinto drama, que seria apresentado em agosto de 1914, não pode ser encenado por

\footnotetext{
44 Traduzido para o inglês Knowledge of the higher Worlds and its Attainment, para o francês L'initiation. Neste livro os capítulos são divididos da seguinte forma: $\mathrm{O}$ conhecimento dos mundos superiores (Condições, Calma interior); Os graus da iniciação (A preparação, A iluminação, Controle dos pensamentos e sentimentos); A iniciação; Considerações de ordem prática; As condições para a disciplina oculta; Sobre alguns efeitos da iniciação; Modificações na vida onírica do discípulo; A aquisição da continuidade da consciência; A cisão da personalidade durante a disciplina espiritual; O guarda do limiar; Vida e morte - o grande guarda do limiar; Posfácio a última edição do autor.

45 Édouard Schuré escrevia sobre religião e ciência. Sua obra mais conhecida é Os Grandes Iniciados, na qual faz relação à atuação da Divindade em todas as civilizações e filosofias, considerando que, embora diferentes na forma, os sábios e os profetas dos tempos mais diversos (Rama, Krishna, Hermes, Moisés, Orfeu, Pitágoras, Platão e Cristo) chegaram a conclusões idênticas.
} 
ocasião da Primeira Guerra Mundial. Esses dramas de mistérios de Rudolf Steiner representaram, no plano da arte teatral dramática, os escritos dele sobre o conhecimento, sobre o homem e seu destino em suas várias vidas terrenas (HEMLEBEN, 1989:105-109).

Paralelamente às representações dos dramas de mistérios, Steiner continuou com seus ciclos de palestras e conferências. Em 1910, proferiu onze conferências sobre o Evangelho segundo João, em Estocolmo, ciclo em Viena, viagem a Klagenfurt, Roma e Palermo, ciclo em Hamburgo, Kristiania, Munique, Berna ("O Evangelho segundo Mateus"). Em 1911, fez oito conferências em Praga sobre "Fisiologia Oculta" e apresentou no Congresso Internacional de Filósofos em Bolonha "Os Fundamentos Psicológicos e a Posição Teórico-cognitiva da Teosofia”. Além dos ciclos em Copenhague, Munique, Karlsruhe e Hannover realizou, também, conferências isoladas em Lugano, Milão, Neuchätel e Berna. Visita a Firenze em 1912, e ciclos de palestras em Helsingfors, Norrkoeping, Kristiania, Munique e Basiléia. Ainda em 1912, "O Evangelho segundo Marcos" em Colônia e conferências isoladas em St. Gallen, Viena, Klagenfurt, Graz, Praga, Estocolmo, Copenhague, Milão e Berna ${ }^{46}$.

É, também, em 1912, que ocorreu a criação da Euritmia ${ }^{47}$. A Euritmia de Steiner, segundo Hemleben, não deve ser entendida nem como ginástica nem como dança, nem tampouco como mímica. Para Steiner, a Eurritmia nos permitiria ter a "consciência de espírito", pois a Eurritmia torna visível a regularidade e qualidade

\footnotetext{
${ }^{46}$ Conforme quadro cronológico em Hemlenben, Rudolf Steiner, pp. 165-166.

${ }^{47}$ Método de psicomotricidade, ou seja, de associação harmônica entre os ritmos musicais, as afecções por eles sugeridas e o dinamismo corporal, criado pelo músico e pedagogo Émile Jaques-Dalcroze (1865 - 1950) - ver Newton Cunha em Dicionário Sesc: a linguagem da cultura. Steiner desdobrou a eurritmia em tríplice abordagem: como arte teatral, como complemento de educação nas escolas e como eurritmia curativa - ver Hemleben em Rudolf Steiner, pp. 113-114.
} 
espiritual da palavra e do som, através de gesto e movimento, elevando-as a uma vivência artística. Dessa vivência subjetivo-objetiva nasceu a Eurritmia como "linguagem visível", como "canto visível". Hemleben traduziu o que Steiner disse sobre a Euritmia em uma das vinte e três conferências em Dornach, em 1924, um ano antes de sua morte:

[...] pois o euritmizar ${ }^{48}$ é, em certo sentido, um plasmar de expressões e gestos, mas não de gestos transitórios, voluntários e, sim, dos gestos cósmicos, significativos, isto é, daqueles que não podem ser diferentes, que não provém de nenhuma arbitrariedade da alma humana." (HEMLEBEN, 1989:115)

Neste mesmo ano, iniciaram-se os preparativos para a fundação da Sociedade Antroposófica por seus seguidores em Munique (BARFIELD, Rudolf Steiner - uma apresentação, 2005). A criação dessa Sociedade surge em paralelo com as representações dos dramas de mistérios. A ideia era criar um edifício em Munique com um palco especial e que pudesse, ao mesmo tempo, servir de centro para as atividades da Antroposofia na Alemanha. A ideia não foi adiante, mas Steiner ganhou, de amigos da Suíça, um terreno em Dornach, perto de Basiléia, onde, em 1913, começou a construção do que chamou de "Goetheanum"49. (figuras 1.4 e 1.5). Em 1913, paralelo à construção do "Goetheanum", Steiner prosseguia com ciclos de palestras em Munique, Kristiania, Leipzig etc. e conferências isoladas em

\footnotetext{
${ }^{48}$ Hemleben acrescenta uma nota de rodapé para explicar o neologismo para traduzir o termo eurythmisiert, forma verbal criada por Steiner a partir do substantivo Eurythmie - em Hemleben, Rudolf Steiner, p. 115.

49 De acordo com Hemleben, em setembro de 1913 sucedeu a colocação da pedra fundamental, e em abril de 1914, a festa de cobertura. Arquitetos, artistas plásticos e pintores atuaram sob a orientação e cooperação do próprio Rudolf Steiner. Hoje o "Goetheanum" é conhecido e defendido como arquitetura, escultura e pinturas antroposóficas - ver Hemleben, Rudolf Steiner, p. 113.
} 


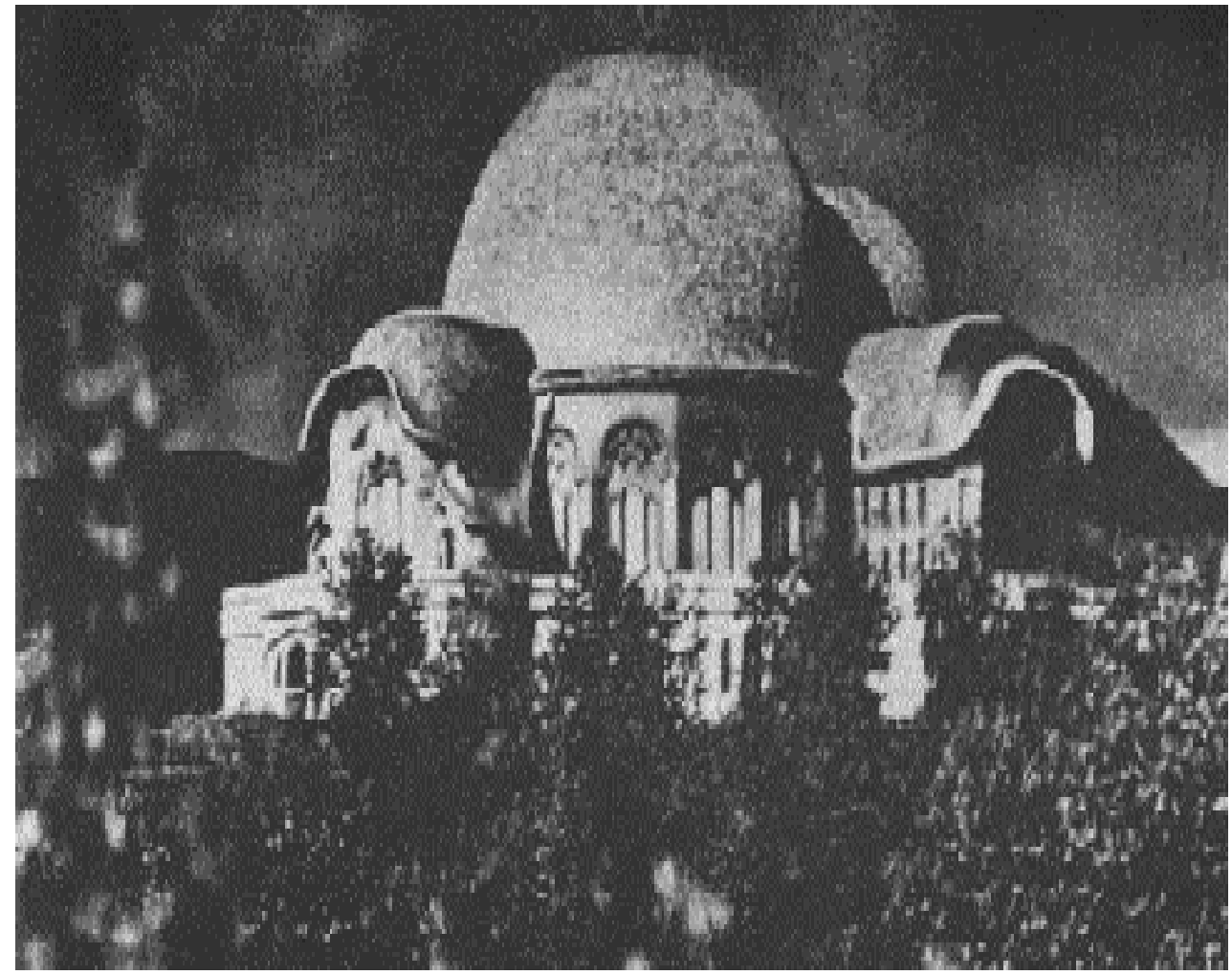

Fig. 1.4 - Foto do primeiro Goetheanum construído em Dornach, Suíça, em 1922 e destruído por ato deliberado de incêndio na passagem do ano de 1922 para 1923 (HEMLEBEN, 1989:145-146, 167).

Disponível em <http://uncletaz.com/goetheanum.html>. 


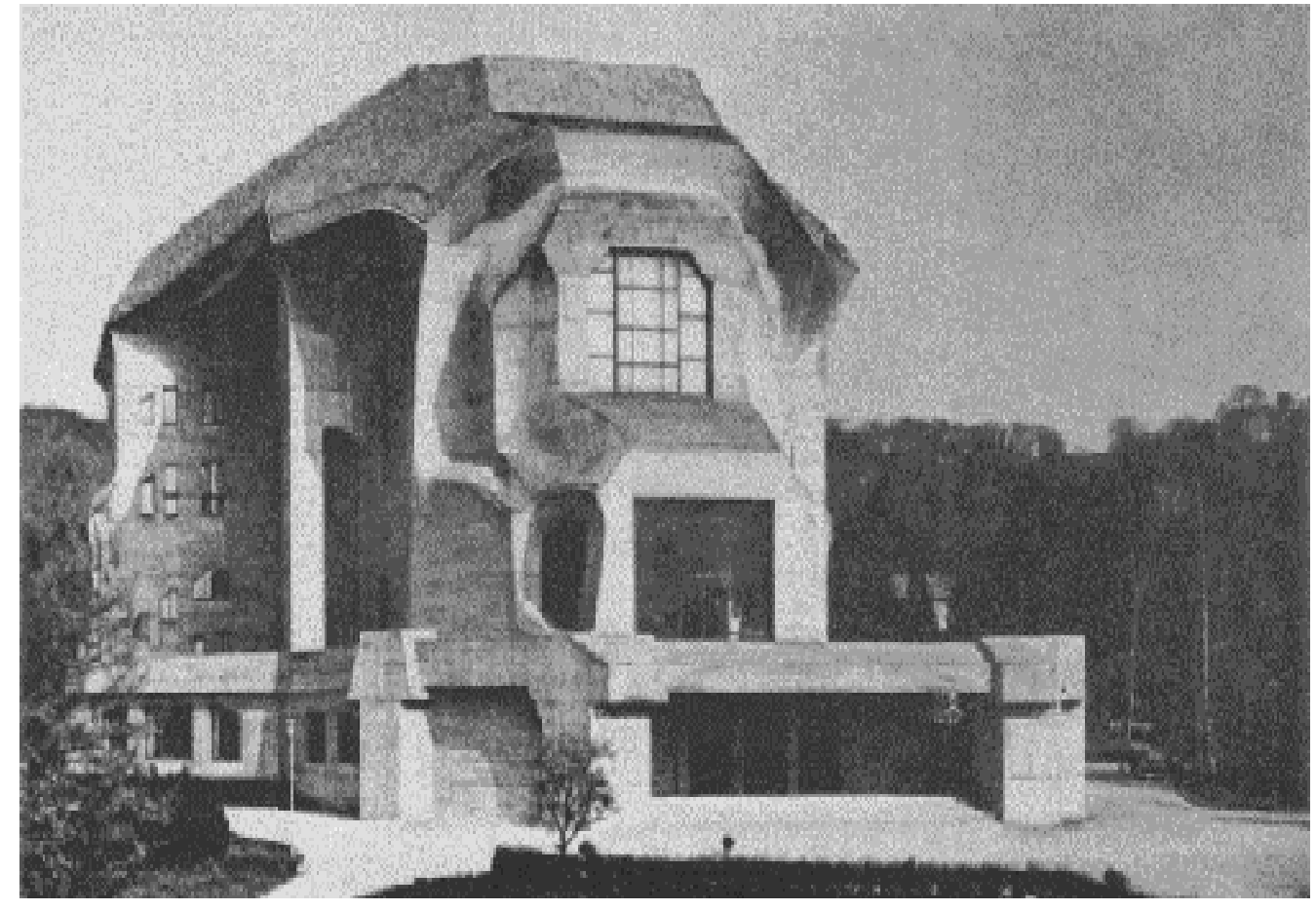

Fig. 1.5 - Segundo Goetheanum construído em 1929 em Dornach, Suíça. O projeto é de Steiner (HEMLEBEN, 1975:160), mas ele faleceu antes do término das obras.

Disponível em <http://uncletaz.com/goetheanum.html>. 
Viena, Praga, Londres, Paris, Copenhague, entre outras ${ }^{50}$.

De 1914 a 1923, Steiner viveu alternadamente entre Dornach e Berlim (HEMLEBEN, 1989:166).

O período compreendido entre os anos de 1917 e 1923 é considerado por Hemleben como a terceira fase do desenvolvimento da Antroposofia. É o início do movimento pela "Trimembração" social, que explicaremos a seguir (HEMLEBEN, 1989:122).

Durante a Primeira Guerra Mundial (1914-1918), Steiner foi acusado por ter favorecido demais o lado alemão. Hemleben discorda desta afirmação e afirma que as palestras proferidas por Steiner são a prova disto. Logo após o término da guerra, Steiner fez um apelo ao povo alemão e ao mundo cultural:

Seguramente edificado por tempo ilimitado - eis o que o povo alemão acreditava ser o seu edifício imperial construído havia meio século. Em agosto de 1914, pensava que a catástrofe bélica em cujo início se via colocado daria prova da invencibilidade desse edifício. Hoje não pode senão contemplar as suas ruínas. Deve haver autoreflexão após uma tal vivência. Pois essa vivência fez com que se provassem como um erro de consequências trágicas a opinião de meio século e nomeadamente os pensamentos dominantes dos anos de guerra. Onde se encontram as causas deste erro fatídico? Esta pergunta tem de incutir auto-reflexão nas almas dos membros do povo alemão. A possibilidade de vida do povo alemão depende de existir ou não, neste momento, a força para auto-reflexão. Seu futuro depende de sua capacidade de colocar-se seriamente a pergunta: como foi que incorri em meu erro? Se se colocar hoje esta pergunta, reduzir-Ihe-á o conhecimento de que, há meio século, fundou um império, porém omitiu-se de propor a esse império uma missão

\footnotetext{
${ }^{50}$ Conforme quadro cronológico em Hemlenben, Rudolf Steiner, p. 166.
} 
oriunda do conteúdo essencial da etnia alemã (HEMLEBEN, 1989:120).

Nasceu, após este apelo, o movimento pela "Trimembração" do organismo social, isto é, desmembrar o antigo sistema estatal em três sistemas: o espiritual, o político e o econômico, isto é, Liberdade no espírito, Igualdade perante o direito, Fraternidade na economia. A ideia central era a de que a vida social da humanidade só poderia torna-se sadia se fosse conscientemente organizada (HEMLEBEN, 1989:122-123).

Provavelmente, o movimento da "Trimembração" do organismo social foi uma primeira tentativa daquilo que viria a ser a Sociedade Antroposófica, pois Hemleben cita que, devido ao egoísmo empresarial e a desconfiança dos funcionários de sindicatos, de um dia para o outro, Steiner chamou seus colaboradores e encerrou esta experiência para a solução da questão social (HEMLEBEN, 1989:124-125).

É em 1919 que Emil Molt, diretor de uma fábrica de cigarros em Stuttgart chamada Waldorf-Astoria ${ }^{51}$, preocupado com os filhos dos operários, pediu que Steiner o ajudasse na fundação de uma escola para estas crianças. Surge, assim, a primeira escola Waldorf 52 . Todas as escolas Rudolf Steiner posteriores seguiram o mesmo modelo dessa (HEMLEBEN, 1989:126-128). Daremos especial atenção a este assunto no capítulo dois desta tese, no qual mostraremos a aplicação dos quatro membros constitutivos do homem à educação e a importância das narrativas para o desenvolvimento e harmonização desses membros.

\footnotetext{
${ }^{51}$ Fábrica esta que oferecia a seus operários cursos de instrução.

52 Segundo Hemleben, quando Steiner faleceu, em 1925, havia duas escolas na Alemanha, uma na Holanda e uma na Inglaterra. Em 1979, havia 57 escolas na Alemanha e cerca de 150 no exterior (Holanda, Inglaterra, França, Escandinávia, Estados Unidos, México, Brasil, Argentina, entre outros) ver Hemleben, Rudolf Steiner, p. 130.
} 
Com a fundação da escola, iniciam-se os cursos e seminários para formação de professores Waldorf. (Ver figura 1.6).

Em 1920, Steiner proferiu três palestras em Dornach sobre São Thomas de Aquino e deu o primeiro e segundo cursos científico-naturais: teoria da luz (10 conferências), teoria do calor (14 conferências), curso de etimologia. Foi também, neste ano, que ele ministrou o curso "pedagógico" em Basiléia (HEMLEBEN, 1989:167).

Ainda em 1920, por conta da palestra de 1911 em Praga sobre o tema "A Fisiologia Oculta" e do lançamento do livro Von Seelenrätseln (De Enigmas da Alma $)^{53}$ em 1917, algumas pessoas pediram a Steiner que contribuísse com algo para a aplicação terapêutica. Foi assim que, do dia 21 de março ao dia 9 de abril de 1920, Steiner realizou em Dornach, Suíça, vinte palestras para médicos e estudantes de medicina (HEMLEBEN, 1989:132).

Nas palestras proferidas em 1921, Steiner abordou temas como "A relação das diferentes disciplinas científico-naturais para com a Astronomia" e "Matemática, experimento científico, observação e resultado cognitivo a partir do ponto de vista da Antroposofia". Foi neste ano que ele ministrou o segundo curso para médicos no qual abordou a Eurritmia curativa e realizou o primeiro e o segundo cursos para teólogos sobre "Antroposofia e Ciência”. É também em 1921 que ele iniciou os cursos para oradores.

Em 1922, Steiner esteve em Stratford, Oxford, Paris, Holanda e Inglaterra discursando sobre Antroposofia e sobre Educação.

\footnotetext{
${ }^{53}$ Traduzido para o inglês The Case for Antroposophy e faltando três seções do original em alemão: Max Dessoir on Antroposophy, Franz Brentano (a memorial address) and the Separation of the psychological from the nonpsychological in Franz Brentano.
} 


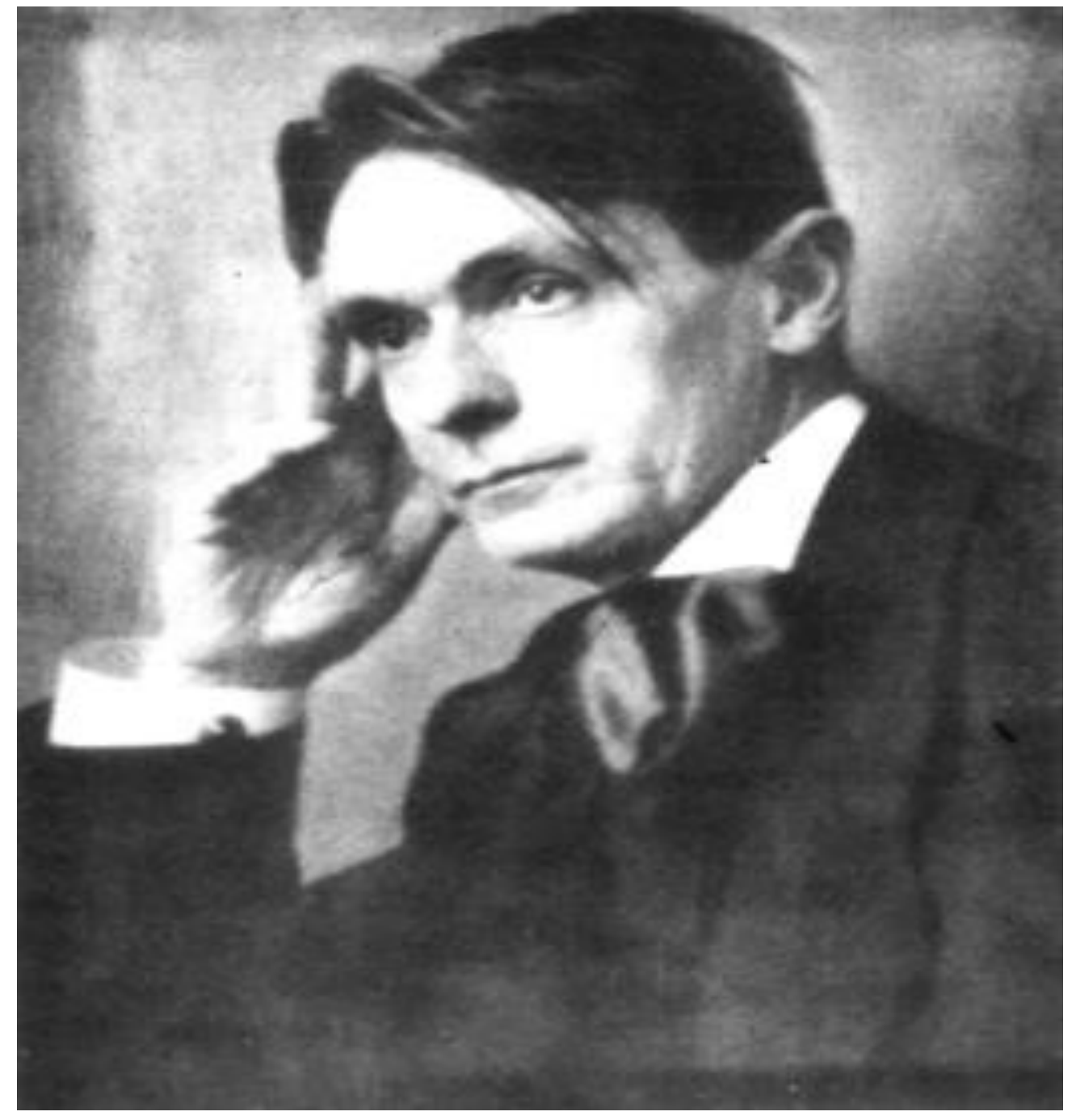

Fig. 1.6 - Rudolf Steiner (1861-1925), fotografia tirada em 1919.

Disponível em <http://uncletaz.com/steinerphotos/stein23.html>. 
Ele trabalhou incessantemente nos sete anos após a Primeira Guerra, período em que elaborou e expandiu a Antroposofia nos campos social, pedagógico, médico, entre outros (HEMLEBEN, 1989:144).

Nesta época, Steiner estava bastante descontente com vários membros pertencentes à formação inicial da Sociedade Antroposófica por não entenderem o seu movimento. Além disso, a Sociedade enfrentava problemas econômicos. E, somado a todos estes fatos, na noite de 1922 para 1923, ocorreu um incêndio que destruiu completamente o "Goetheanum” (HEMLEBEN, 1989:145-146).

Após todos estes acontecimentos, Steiner resolveu fazer uma reforma na Sociedade, criando o que passou a ser conhecido como Sociedade Antroposófica Geral na Alemanha, Noruega, Suíça, Inglaterra, Holanda e Áustria, cujos membros autônomos seriam as sociedades locais. Steiner encarregou-se da presidência e estabeleceu uma série de regras para que pudesse ter a Sociedade que ele havia imaginado durante toda a sua vida (HEMLEBEN, 1989:146-151).

Paralelamente à reestruturação interna e externa da Sociedade Antroposófica, foi fundada a Escola Superior Livre para a Ciência Espiritual. O objetivo da Sociedade passou a ser a promoção de pesquisa no campo espiritual e a Escola Superior Livre seria a pesquisa propriamente dita (HEMLEBEN, 1989:152).

De 1924 a 1925 passaram a ser publicados semanalmente capítulos da autobiografia de Steiner, Mein Lebensgang, na revista Das Goetheanum. Steiner faleceu antes de terminá-la, no dia 30 de março de 1925, em Dornach (HEMLEBEN. 1989:168).

Além dos livros e palestras, Steiner deixou uma série de poemas utilizados até hoje como Meditação nas Escolas Waldorf para diversas ocasiões. Escolhemos 
um deles para encerrar este subcapítulo:

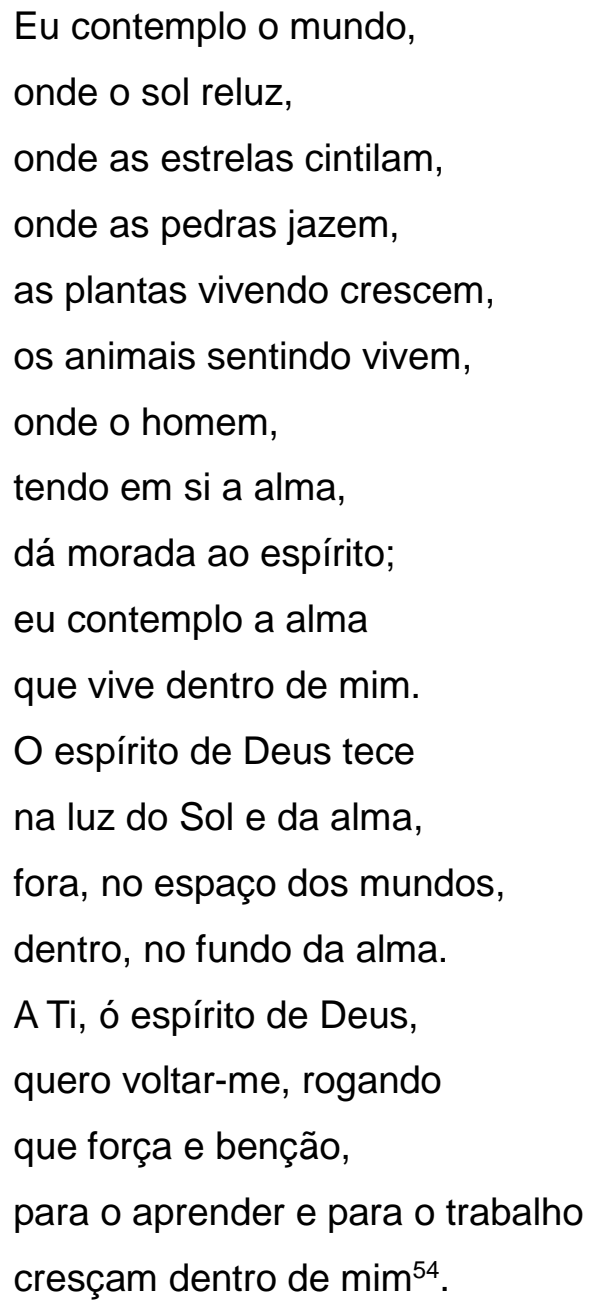

\subsection{ALGUMAS CONSIDERAÇÕES}

Os aspectos abordados nas seções anteriores proporcionam uma ideia geral da formação científica e filosófica de Steiner, bem como do contexto em que ele viveu e das possíveis influências que sofreu.

\footnotetext{
${ }^{54}$ Esta é uma tradução literal do poema da manhã das classes superiores (equivalente ao nosso ensino médio) escrito por Steiner em 26 de setembro de 1919. A tradução foi publicada pela Seção Pedagógica da Escola Livre de Ciências Espirituais Goetheanum, Dornach, Zur Vertiefung der Waldorfpädagogik, $3^{\mathrm{a}}$. ed., p. 105 (tradução literal), p. 106 (original em alemão), p. 107 (manuscrito do poema com rabiscos de Steiner), 2000.
} 
Pode-se perceber que a formação de Steiner foi bastante eclética. Em seus estudos, ou mesmo informalmente, ele teve contato com aspectos da geometria, física, química, biologia, incluindo as teorias evolutivas de Darwin e Haeckel, fisiologia (Helmholtz), psicologia (Brentano), línguas clássicas, literatura clássica e alemã (Goethe e Schiller), filosofia (Kant e Fichte), sendo que sua tese de doutoramento foi sobre Fichte, lógica, silogismo e economia social (ideias de Marx e Engels), entre outros. Certamente, houve aspectos em que este contato foi maior e nos quais ele se aprofundou mais, como, por exemplo, acerca da teoria do conhecimento de Goethe sobre a qual ele escreveu um livro, além de ser editor de suas obras. Ele também teve um contato maior com as ideias de Nietzche, tendo publicado um livro sobre ele e organizado sua biblioteca.

Steiner também tomou conhecimento da história do catolicismo, seus símbolos e dogmas, tendo convivido com vários padres.

Na época em que ocorreu a formação de Steiner, adotava-se de um modo geral a visão epistemológica empírica, de acordo com a qual a ciência deveria se basear em fatos obtidos pela observação e procurar generalizá-los através de leis, que é o que busca Brentano, por exemplo. Entretanto, Steiner foi bastante influenciado também por suas leituras de Goethe, um representante do romantismo alemão e da Naturphilosophie. O movimento da Naturphilosophie admitia a existência de um universo unificado dotado de uma alma em que tudo influía sobre tudo. O movimento romântico alemão procurava unir a mente humana com a dimensão espiritual da Natureza. Steiner, por outro lado, admirava as ideias biológicas de Goethe, principalmente as evolutivas, através da doutrina da metamorfose que aparece no trabalho de botânica do mesmo que Steiner leu e 
mencionou.

Durante o período de formação de Steiner, aceitava-se, de um modo geral, as concepções de energia, matéria, espaço e tempo, admitidas pela física clássica. Entretanto, entre 1895 e 1905, ocorreu uma série de descobertas que levaram ao surgimento da mecânica quântica e do conceito de relatividade, questionando diversas concepções da física clássica. Neste período, Steiner proferiu palestras e escreveu trabalhos.

Durante a formação de Steiner, em vários países da Europa havia uma tentativa entre os espiritualistas de apresentar o espiritualismo como uma questão científica. Tentativa contrária às exigências científicas da época e na contramão da ideia de "progresso" que se impunha em um mundo cada vez mais tecnicista e materialista.

As concepções de Steiner, que serão apresentadas no próximo capítulo, exemplificam a força com que ele procurou manter as ideias espiritualistas reinantes não só na Europa de seu tempo, como também no Oriente e no pensamento de homens da Antiguidade. 


\section{O HOMEM, A CRIANÇA, A LINGUAGEM E AS NARRATIVAS EM STEINER}

Este capitulo apresenta alguns pontos importantes que fazem parte da visão de Rudolf Steiner a respeito do querer, do sentir e do pensar. Inicia apresentando a concepção do homem em Steiner que aparece, principalmente, nas obras A Filosofia da Liberdade e A Arte da Educação I - O estudo geral do homem, uma base para a Pedagogia. Descreve o pensar em relação ao sentir e, em seguida, o querer em relação ao sentir. Faz uma comparação entre a educação voltada ao raciocínio e a educação voltada ao artístico que estão presentes nas obras A Arte da Educação I, já citada, e também nas obras $A$ Arte da Educação II - Metodologia e didática no ensino Waldorf e A Arte da Educação III - Discussões pedagógicas. Finaliza com a apresentação de suas ideias sobre a importância da arte e, mais especificamente, a importância das narrativas para a formação do ser humano integral, harmônico e espiritualmente livre.

Antes de prosseguirmos, é importante explicar que os três volumes da Arte da Educação são transcrições de um curso pedagógico ministrado por Steiner, no período de 27 de agosto a 6 de setembro de 1919, para os professores da primeira Escola Waldorf Livre e também para pessoas interessadas em suas ideias. O curso abrangeu três etapas distintas: catorze conferências sobre a Antroposofia como estudo geral do homem e base para uma Pedagogia; catorze conferências que tratavam da metodologia e da didática a ser empregada no ensino e na educação 
Waldorf; discussões pedagógicas apresentadas em quinze colóquios e três palestras sobre o currículo. Nesta última parte, há também algumas considerações feitas pelos alunos (professores e interessados) em forma de debate que visam à elaboração prática de certas disciplinas e os caminhos para solução de alguns problemas educacionais propostos.

\subsection{A CONCEPÇÃO DO HOMEM EM STEINER}

O homem para Steiner é tetramembrado, isto é, formado por quatro membros - o eu, o corpo astral (ou corpo das sensações), o corpo etérico (ou corpo vital) e o corpo físico. Durante a vida espiritual, a entidade é formada apenas pelo eu, que é o portador da alma e do espírito (STEINER, 1995:23).

De acordo com Steiner, durante a vida espiritual a entidade humana é formada por alma e espírito, ou, pela união de duas tríades: a alma (alma da consciência, alma do intelecto ou sentimento e alma da sensação) e o espírito (personalidade espiritual, espírito vital e homem espírito). A partir do momento que passa a viver na terra, a entidade humana recebe o corpo orgânico ou organismo corpóreo, que também é uma tríade (corpo das sensações ou astral, corpo etérico e corpo físico) e que deve se unir aos três reinos da natureza (mineral, vegetal e animal). Consequentemente, quando a entidade recebe o corpo físico, novamente se unem duas tríades (STEINER, 1995:23).

Ainda segundo o autor, o corpo físico e o corpo etérico fazem parte da corrente hereditária. Pode-se constatar isso, principalmente, no corpo físico do homem no qual normalmente é possível perceber as semelhanças com os pais, tios 
etc. O corpo etérico, por sua vez, está intimamente ligado ao corpo físico, visto que é ele que impede o mesmo de perecer, degenerar. O corpo astral está mais ligado à corrente das vidas passadas, ao núcleo essencial do homem. Ele é como um mediador interno que irradia suas qualidades essenciais para o exterior. $\mathrm{O}$ eu é o corpo que paira acima de todos (STEINER, O Mistério dos Temperamentos:26) (Ver figura 2.1).

O Eu, ou anímico-espiritual, pertence exclusivamente ao homem e o diferencia de todas as criaturas dos reinos mineral, vegetal e animal. Este membro é portador do atuar e do querer dirigidos ao exterior.

O corpo astral é portador de tudo o que é prazer, sofrimento, alegria e dor, instintos, impulsos, paixões, enfim, todas as sensações e representações que comovem o homem. Este membro está relacionado com o reino animal.

O corpo etérico é considerado por Steiner como um construtor ou plasmador do corpo físico. Nele encontram-se os membros superiores suprassensíveis da natureza humana que regulam interiormente os processos de crescimento e vida. Estes membros são tão reais e essenciais quanto o corpo físico. Ao coração físico subjaz um "coração etérico", ao cérebro físico subjaz um "cérebro etérico" etc. Este membro, ou corpo, o homem tem em comum com o reino vegetal.

O corpo físico é aquilo que o homem tem em comum com toda a natureza exterior. Ele é uma soma das leis químicas e físicas e é o que o homem tem em comum com o reino mineral.

A concepção correta do homem é aquela que respeita suas relações com o Macrocosmo, isto é, o quanto o ser humano representa em seu microcosmo as 


\section{HOMEM TETRAMEMBRADO}

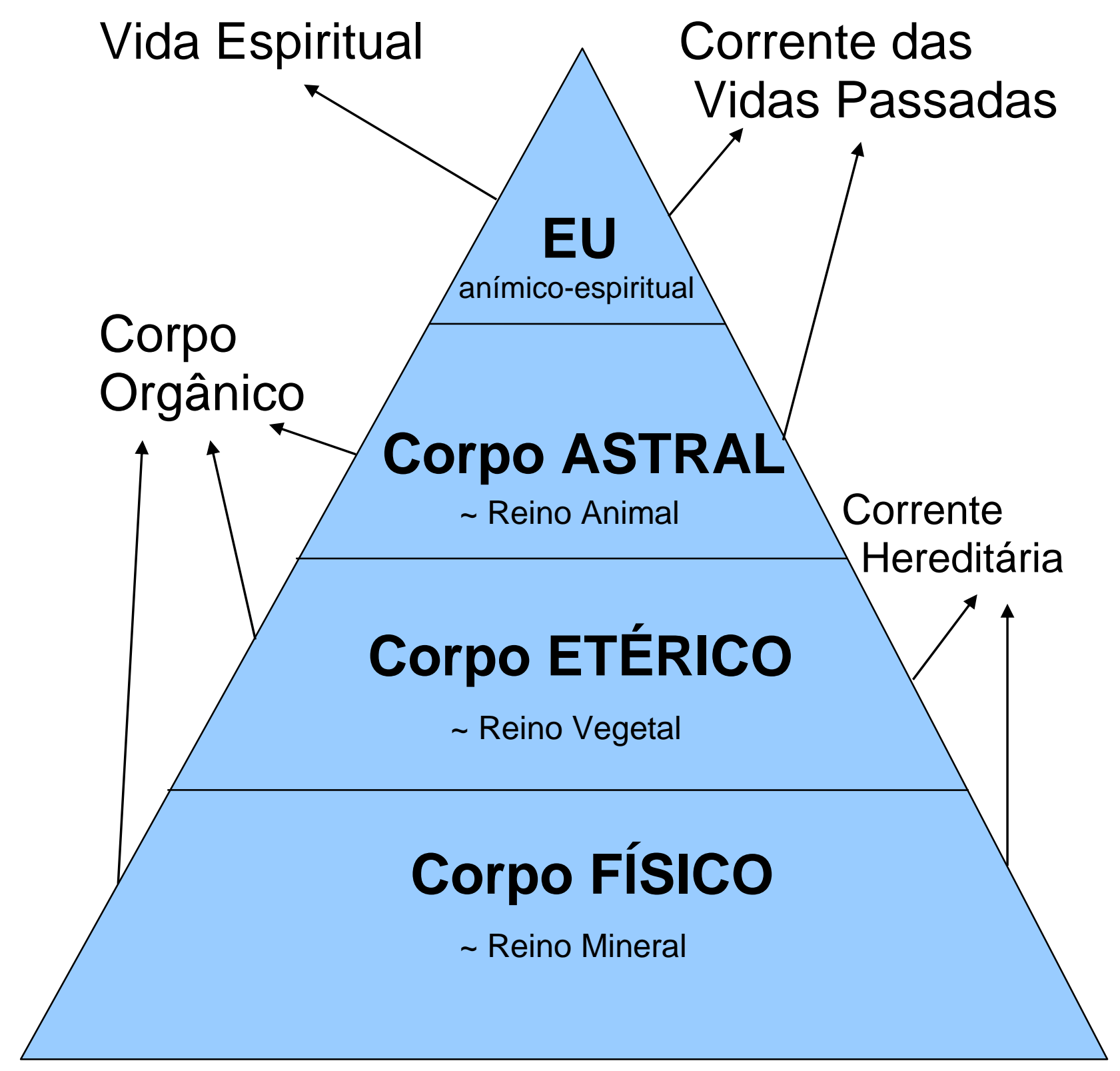

Fig. 2.1 - Desenho ilustrativo sobre a concepção do homem tetramembrado de Steiner. 
mesmas forças presentes nos três reinos da Natureza - o mineral, o vegetal e o animal - e o quanto está presente em sua alma e em seu espírito das forças do Universo. Por isso, Steiner considerava que um dos maiores erros do materialismo e do cientificismo foi relacionar a figura humana ao animal, desprezando, desta forma, os demais reinos da Natureza e as demais forças existentes no Universo, sendo que ambas estão presentes e atuantes no decorrer da vida de cada homem, do seu nascimento até a sua morte.

O homem, para Steiner, é uma entidade espiritual una com o cosmo, porém quando passa a viver na terra, quando recebe seu corpo físico, essa unidade é rompida e o homem experimenta sua dupla natureza: eu e o mundo (ou interior e exterior). Inicia-se a partir daí uma busca pela unidade perdida que, de acordo com Steiner, explica os motivos da insatisfação presente em todos os homens e da sua constante curiosidade e busca por explicações dos fatos e acontecimentos.

Para Steiner, era necessário harmonizar os quatro membros constitutivos do homem, impedindo que um deles se acentuasse mais do que os demais. $E$ isto poderia ser obtido por meio da educação do querer, do sentir e do pensar. Como será mostrado nas próximas seções deste capítulo.

\subsection{A CONCEPÇÃO DO PENSAR E DO SENTIR EM STEINER}

Como foi explicado na seção anterior, o homem é uma entidade espiritual una com o cosmo, porém quando passa a viver na terra, quando recebe seu corpo físico, essa unidade é rompida e o homem experimenta sua dupla natureza: eu e o mundo 
(ou interior e exterior).

Para Steiner, a observação e o pensar são pontos de apoio iniciais para qualquer esforço espiritual do homem, isto é, para que o homem recupere a unidade perdida. De acordo com ele, é por meio da observação que o homem percebe os fatos que formam o círculo de suas experiências, e ele considerava que por meio da observação "nos é dado o conteúdo de todas as nossas sensações, percepções, contemplações, sentimentos, atos de vontade, imagens oníricas e da fantasia, representações, conceitos e ideias, inclusive ilusões e alucinações" (STEINER, 1979:34). Em outras palavras, enquanto o homem observa um objeto, este se manifesta como se lhe fosse dado; enquanto pensa, percebe-se a si mesmo como um ser ativo - "considera o objeto como objeto e a si mesmo como sujeito pensante. Pelo fato de aplicar seu pensar à observação, tem consciência dos objetos; pelo fato de aplicá-lo a si mesmo, tem consciência de si mesmo" (STEINER, 1979:49). A proposta de Steiner era procurar um mundo espiritual no mundo das ideias.

Para ele, o pensar e o sentir correspondem à dualidade do ser, sendo que o pensar é uma atividade primordial e universal, enquanto o sentir é individual. Nas palavras de Steiner, "o mundo das ideias que está em meu íntimo é o mesmo que vive nos demais homens" (STEINER, 1979:130) e o que diferencia um homem dos demais é a forma como as ideias resplandecem em cada homem em particular. Ele citou o seguinte exemplo:

(...) Não só vejo uma árvore, mas sei também que sou eu quem a vê. Posso saber, além disso, que enquanto observo a árvore, alguma coisa ocorre no meu interior. Ao desaparecer a árvore do horizonte de minhas percepções, subsiste em minha consciência um resíduo do acontecimento, ou seja, uma imagem da árvore. Esta imagem se 
associou à minha individualidade durante a observação, enriquecendo-a; um novo elemento agregou-se ao seu conteúdo. É a este elemento que denomino representação da árvore. Se não experimentarmos a existência das representações na percepção de minha individualidade, jamais poderia saber das mesmas (STEINER, 1979:55).

O pensar, em Steiner, não é individual como o são ter uma sensação ou sentir (perceber). O pensar é universal e ganha o caráter individual em cada homem na relação que estabelece com os sentimentos e as sensações particulares. Para ele, a distinção dos homens entre si se deve exatamente a esta coloração particular do pensar universal. O que o leva a concluir que, "enquanto percebemos e sentimos, somos seres particulares; enquanto pensamos, somos o ser universal que tudo penetra" (STEINER, 1979:74).

De acordo com Steiner, a percepção constitui apenas uma parte da realidade total, o conceito constitui a outra parte. Desta forma, cada coisa com a qual o ser humano se defronta, cada acontecimento que presencia, se constitui em sua totalidade por meio da união entre a percepção e o conceito. O que faz com que ele considere o ato de conhecer como sendo a síntese entre a percepção e o conceito. Em suas palavras:

É a cognição que há de proporcionar-nos a harmonização, a combinação dos dois elementos, o interior e o exterior [...] Se queremos conhecer a natureza dos nossos atos, só o podemos mediante a contemplação pensante, isto é, incorporando-os ao sistema mental de nossos conceitos e ideias (STEINER, 1979:74-76)

É por isso que ele considerava a intuição e a observação como fontes iniciais 
do conhecimento. É importante explicar que Steiner definiu a intuição como sendo a maneira como o conteúdo do mundo é apreendido inicialmente. Sempre que se depara com um objeto do mundo exterior, ou um acontecimento, surge no interior do homem uma intuição correspondente. De acordo com Steiner:

Para nós, o mundo se decompõe em adiante e atrás, abaixo e acima, causa e efeito; objeto e representação, matéria e energia, objeto e sujeito etc. Os objetos que à observação parecem separados, articulam-se, por meio do mundo uno e coerente de nossas intuições, formando um conjunto; e por meio do pensar voltamos a reunir tudo o que a percepção separou (STEINER, 1979:77-78).

Em Steiner, a intuição é para o pensar o que a observação é para a percepção. Portanto, compete ao pensar, e não à percepção, formar laços entre o subjetivo e o objetivo. Desta forma, o homem forma representações das relações que ele estabelece com as coisas e os acontecimentos do mundo. Isto produz um movimento constante de afastamento e aproximação, ou seja, produz um movimento constante entre afastar sua atenção do que existe fora, no mundo exterior, e aproximar sua atenção, ou mergulhar no universo interior de suas representações. A cada contato, a cada acontecimento, novas representações são produzidas. É por que, para Steiner, o pensar "é algo que se pode vivenciar por meio da percepção, tanto interiormente como fora, no mundo" (STEINER, 1979:81-83). Conforme explicitado na seguinte citação:

No momento em que uma percepção aparece em meu campo de observação, ativa-se em mim também o pensar [...] Um membro de meu sistema mental, uma intuição determinada, une-se à percepção. 
O que resta ao desaparecer esta última do meu campo visual? Minha intuição, com a referência à percepção determinada, que se formou no momento de perceber. O grau de vivacidade com o qual posso, mais tarde, voltar a representar-me essa referência, depende do modo como funciona meu organismo espiritual corpóreo. A representação não é senão uma intuição aplicada a uma determinada percepção, um conceito que alguma vez esteve relacionado com uma percepção, e que conserva a referência a esta última. O meu conceito "leão" não se formou a partir de minhas percepções de leões; formou-se, sim, da percepção, a minha representação de leão. Posso muito bem fazer compreender o conceito de leão a uma pessoa que jamais tenha visto um leão em sua vida, mas sem sua própria percepção jamais me será possível dar-Ihe uma representação viva (STEINER, 1979:86).

Portanto, para Steiner, as representações mentais conferem à vida conceitual uma nota individual, visto que se relacionam com os sentimentos particulares, individuais de cada ser humano, com as sensações de prazer ou desagrado que as coisas do mundo provocam em cada ser.

Posteriormente, no livro A Arte da Educação I - O Estudo Geral do Homem uma base para a Pedagogia, Steiner complementará essa noção considerando que a possibilidade de captarmos algo por meio das representações provém do fato delas possuírem um caráter pictórico, um cunho de imagem. Isto faz com que elas não tenham uma existência real, sendo meras imagens. Por isso, ele fez uma crítica à maneira como foi interpretada a frase de Descartes: Cogito, ergo sum [Penso, logo existo], pois, para ele, "no grande circuito do cogito não está o sum, mas o non sum. Em outras palavras, o que existe dentro dos limites do meu conhecimento não sou eu; é apenas imagem" (STEINER, 1995:28-29).

As imagens, as representações, têm grande importância nas concepções de 
Rudolf Steiner. Isto fica claro na seguinte citação:

O amor, a compaixão, e o patriotismo são motivos do agir humano que não podem ser explicados ou resolvidos ao nível dos conceitos frios do entendimento (...) A compaixão só se manifesta no meu coração quando se apresenta à minha consciência, de antemão, a imagem (a representação) de alguém que provoque esse sentimento. O caminho para o coração atravessa a mente (a cabeça), e a isso nem o amor faz exceção (...) o amor baseia-se nas imagens que formamos do ser amado, e quanto mais ideais forem estas imagens, tanto mais sublime é o amor. O pensamento é, também aqui, o pai do sentimento. Diz-se, comumente, que o amor é cego aos defeitos do ser amado. Pode-se, porém, inversamente asseverar que o amor faz ressaltar precisamente suas qualidades. Mesmo à frente dessas qualidades, muitos não as notam; e se alguém as vê, por esse motivo nele desperta o amor. Esse alguém não fez mais do que formar uma imagem daquilo que a inúmeros outros não suscitou imagem alguma. Estes carecem de amor porque Ihes falta a imagem, ou seja, a representação (STEINER, 1979:22-23).

Para Steiner, o degrau ou o estágio mais elevado da vida individual é o pensar conceitual. É o último estágio dos quatro definidos por ele com relação à atuação do querer no pensar. Querer que para Steiner é vontade espiritual (ou impulso, ou força impulsiva) que determina a ação do homem, os atos da vontade. $O$ primeiro degrau é o estágio da percepção; o segundo, o do sentir; o terceiro, o do pensar e do representar; e, por fim, o estágio do pensar conceitual. Em cada um desses quatro estágios atuam diferentes forças impulsivas que serão apresentadas na próxima seção. 


\subsection{A CONCEPÇÃO DO QUERER EM STEINER}

Para compreender o querer em Steiner, assim como o pensar e o sentir, é necessário considerá-los como atividades da alma que atuam no espírito e no corpo físico do homem. Na alma eles estão interligados não havendo a possibilidade de separá-los totalmente. No corpo físico é mais fácil perceber uma separação, embora, também no corpo físico exista uma interligação entre eles. Esta interligação é mediada pelo sentir.

O sentir atua como um mediador entre o querer e o pensar participando e influindo em ambos. Na criança, o sentir está amalgamado ao querer e, com o passar do tempo, conforme a criança lida com o mundo e com as coisas do mundo, ocorre um desligamento paulatino do sentir com o querer e sua posterior ligação com o pensar. O querer não desaparece no adulto, mas se transforma em vontade livre (ou vontade espiritual). A vontade livre é definida por Steiner como motivos que atuam no homem consciente, e que são determinados por sua moral e por sua ética de acordo com a disposição do seu caráter. São os impulsos ou os fins da moral (STEINER, 1979:119).

Para Steiner, a vontade é "espiritual" e é portadora dos sentimentos que atuam em uma constante alternância entre simpatia e antipatia. Ele considerava que o conhecer, a antipatia, a memória e o conceito atuavam nos nervos corporificandose, isto é, atuando em direção ao corpo. Ao passo que, o querer, a simpatia, a fantasia e a imaginação atuavam no sangue espiritualizando-se, ou seja, indo do corpo ao espírito, do interior do homem para o exterior. Ele apresentou o seguinte esquema no livro A Arte da Educação I (STEINER, 1995:35): 


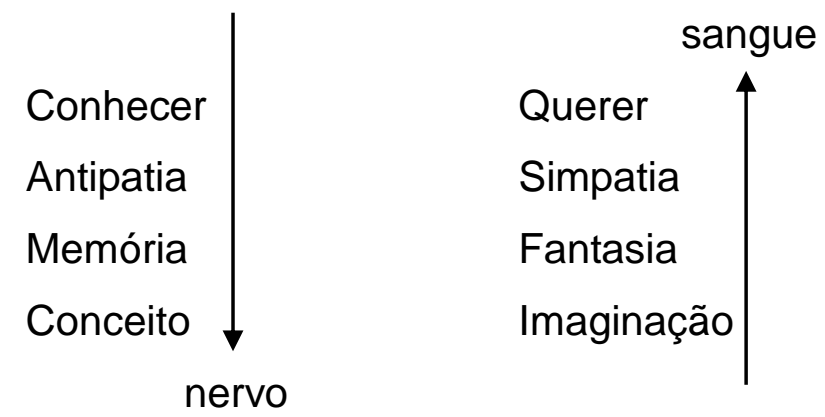

Para entender melhor este conceito em Steiner é necessário analisar a atuação dos atos de vontade, ou da atividade volitiva (ou o querer mediado pelo sentir e sua atuação no pensar) em cada ser individual e sua relação com os quatro membros constitutivos do homem. Nas palavras de Steiner:

(...) a atividade volitiva é "principalmente" volitiva, e contém a corrente subjacente do pensar; a atividade pensante é "principalmente" pensante, e leva como corrente subjacente a atividade volitiva. Portanto, ordenar intelectualmente lado a lado já não é possível no caso das atividades anímicas, pois uma transborda para a outra (...). O mesmo acontece com todos os sentidos, mas também com os membros motores que servem ao querer. Em nosso querer, em nossos movimentos penetra pelos nervos o elemento cognitivo, e pelas veias o elemento volitivo. (STEINER, 1995:65-66).

Os atos de vontade provocados pela percepção e, em particular, pela percepção dos sentidos, são espontâneos, isto é, ocorrem sem a intervenção do conceito ou do sentimento. Eles atuam no corpo físico do homem instintivamente satisfazendo necessidades inferiores como fome, sede, sexo, entre outros. Portanto, no corpo físico a vontade é instinto e provém de uma percepção dos sentidos (STEINER, 1979:120; 1995:56). 
O corpo físico é permeado pelo corpo etérico que captura e transforma a vontade instintiva em impulso. O corpo astral permeia o corpo etérico apoderando-se do impulso, interiorizando-o e elevando-o à consciência, transformando-o em cobiça. Ao ser captado pelo eu, a cobiça é transformada em autêntico motivo da vontade (STEINER, 1995:57). Nas palavras de Steiner:

O individual em mim não é meu organismo com seus apetites e sentimentos, mas o mundo uno das ideias que nele resplandece. Meus apetites, instintos e paixões não fazem mais do que provar que pertenço à espécie geral 'homem', o fato de nestes apetites, paixões e sentimentos se manifestar, de forma peculiar, um elemento imaterial, constitui minha individualidade. Por meus instintos e apetites sou um homem igual ao qual pode haver uma dúzia; pela forma especial da ideia que permite distinguir meu 'Eu' dos alheios, sou um indivíduo. No tocante a diferença em minha natureza animal, somente um ser diferente de mim poderia distinguir-me dos demais; através do meu pensar, isto é, pela concepção ativa daquilo que, como elemento mental, manifesta-se através do meu organismo, eu mesmo me diferencio dos demais. Por conseguinte, não se pode dizer que o ato do criminoso proceda da ideia. É, sim, precisamente uma característica dos atos criminais o fato de derivarem dos elementos que, no homem, não possuem afinidades com as ideias (STEINER, 1979:128-129).

Para Steiner, no criminoso os impulsos prevaleceram sobre os motivos, não houve uma integração harmônica entre os quatro membros constitutivos. O corpo físico prevaleceu sobre os demais corpos. O fato dos impulsos prevalecerem sobre os motivos, indica que não houve uma evolução nos estágios da atividade volitiva mediados pelo sentir, o que comprometeu o estágio do pensar e do representar e, consequentemente, o estágio do pensar conceitual. 
O que ocorre no corpo físico (instinto), no corpo etérico (impulso) e no corpo astral, ou corpo das sensações (cobiça) é captado pela alma e se transforma em motivo. Da alma passa ao espírito no qual irá se transformar em desejo (aspiração), intenção e resolução. Conforme a apresentação esquemática de Steiner:

Home-espírito:

Espírito vital:

Personalidade espiritual
Resolução

Intenção

Desejo (aspiração)
Alma da consciência

Alma do intelecto

Alma da sensação

Corpo das sensações:

Corpo etérico:

Corpo físico:
Motivo

Cobiça

Impulso

Instinto

Portanto, a vontade livre de Steiner é baseada no individualismo ético, baseada na ideia de que o mundo das ideias que vive no íntimo de cada homem é o mesmo que vive nos demais homens. Não é simples obediência às regras morais, mas uma crença interior de algo que é comum no pensar conceitual de todos os homens e visa ao bem de todos, visto que o mundo das ideias é uno, isto é, o mundo das ideias que vive em cada ser é o mesmo que vive em todos os seres. Em suas palavras:

A natureza faz do homem um mero ser natural; a sociedade 
transforma-o em um ser que age conforme leis; só ele pode fazer de si mesmo um ser livre. A natureza libera o homem em certa fase de sua evolução; a sociedade conduz esta evolução uns passos adiante; o último polimento dá-se o homem a si mesmo (STEINER, 1979:133-134).

É baseado no que foi exposto nestas três seções, que Steiner apoiava suas críticas aos pedagogos de sua época e ao ensino puramente racional e intelectual. Ensino que, de acordo com ele, educava apenas a cabeça, não atuando no ser humano por inteiro, desprezando sua constituição físico-corpórea, pois o homem não é só cabeça, e, acima de tudo, sua constituição anímico-espiritual. Para ele, o cientificismo e o materialismo de sua época, eram responsáveis pela formação do homem egoísta de seu tempo. Em suas palavras: "a pedagogia não pode ser uma ciência - deve ser uma arte" (STEINER, 1995:125).

Por meio da arte é possível permear o homem por um querer imbuído de sentimento e um sentir imbuído de vontade. É possível permear o homem por inteiro. Nas palavras de Steiner: "o elemento artístico tem, já de per si, a propriedade de alegrar o homem não só uma vez, mas sempre de novo" (STEINER, 1995:64).

E foi a partir da aplicação destas concepções que ele estabeleceu a sua Pedagogia Waldorf.

\subsection{O QUERER, O SENTIR E O PENSAR APLICADOS À EDUCAÇÃO}

A educação intelectual, para Steiner, visa ao que é morto no homem, ao que é material e não espiritual, é vontade envelhecida. A educação puramente racional 
impede o desenvolvimento do homem integral, uno, harmônico, pois não atua sobre o sentimento, que é vontade viva ainda dormente (STEINER, 1995:62).

A educação proposta por ele, leva em conta, justamente, a atuação mediadora executada pelo sentir, tanto em relação ao querer, quanto em relação ao pensar. Em suas palavras, "o sentimento tanto é conhecimento quanto vontade ainda embrionários - conhecimento refreado e vontade refreada" (STEINER, 1995:71).

De acordo com Steiner, a educação deve visar um correto desenvolvimento da vida sentimental da criança. Ao mesmo tempo, a educação e o ensino não podem perturbar o crescimento e o desenvolvimento do corpo físico, que é muito acentuado da infância até o final da puberdade. Para ele, é possível respeitar os dois desenvolvimentos - o sentimental e o físico - quando a criança é ensinada a partir da vontade, da linguagem e do agir do adulto que ela imita nos primeiros sete anos de vida, passa a respeitar como autoridade dos sete aos catorze anos de idade e estabelece seu próprio juízo e julgamento na puberdade.

Autoridade, em Steiner, deve ser compreendida como o respeito que a criança deve ter pelo que o professor, ou os adultos com os quais ela convive, já aprenderam e alcançaram e que elas também deverão aprender e alcançar um dia por meio do que lhes é ensinado na escola e em casa (STEINER, 2003:45-46). Dito por ele:

Não se trata, portanto, de a criança logo formar um juízo a respeito de tudo, e sim de que ela, entre o sétimo e o décimo quinto ano de vida, assimile pelo amor e pela autoridade do professor tudo o que deve assimilar (...) "Veja, os adultos têm livros e sabem ler. Você ainda não sabe ler, mas vai aprender; e quando houver aprendido 
também tomará os livros nas mãos e aprenderá neles o que os adultos aprendem (...) além de aprender a ler também aprenderá a escrever" (...) O importante, pois, é tornar consciente o que a criança está fazendo (STEINER, 2003:46-47).

No sentido metodológico, o fato das crianças, nas primeiras aulas, saberem que ainda não sabem ler, escrever ou fazer contas, mas que irão aprender todas essas coisas na escola, imprime nas crianças a esperança, o desejo, a intenção. Deixar as crianças na expectativa tem uma atuação muito favorável na formação da vontade do ser humano em desenvolvimento.

O bom ensino deve ser permeado pelo artístico. Por isso, o desenho, a pintura, a música (por meio do cantar e do tocar algum instrumento musical), a modelagem, devem fazer parte das atividades diárias da criança na escola. A partir da sensibilidade artística, que é inerente ao homem, consegue-se solicitar o ser humano inteiro, e não apenas a cabeça. Ao sentir os membros e o tórax, por meio da sensibilidade que é aguçada pela arte, transfere-se para a cabeça o que vibra no corpo todo. A criança que aprende desta forma, isto é, por meio de um ensino que alterna e mescla o artístico com o cognitivo em tudo o que lhe é apresentado no ensino, posteriormente, se inclinará, de acordo com Steiner: "com todo o seu ser, a possuir um interesse pelo mundo". E ele complementa dizendo que: "Todo e qualquer método deve ser mergulhado no artístico. A educação e o ensino devem tornar-se uma verdadeira arte. Ao saber cabe apenas estar subjacente" (STEINER, 2003:13-14).

O ensino racional atua apenas na cabeça, fazendo com que as demais partes do corpo físico (tórax e membro) não se desenvolvam adequadamente. Quando isto acontece, as demais partes do corpo físico do homem são orientadas 
de acordo com seus instintos, instintos animalescos que esgotam emocionalmente o ser humano. Posteriormente, teremos homens egoístas (STEINER, 2003:14).

De acordo com Steiner, em um bom ensino, o desenho, a pintura e a música devem preceder o ensino da escrita e da leitura. Isto está exemplificado na seguinte citação:

Façamos a criança primeiro desenhar e depois desenvolver, daquilo que desenhou, as formas da escrita, e assim estaremos educando do homem-membros para o homem-cabeça. Mostremos à criança, digamos, um $F$. Se ela tiver de observar o $F$ e depois copiá-lo, então pela observação estaremos atuando primeiro no intelecto, que por sua vez adestra a vontade. Este é o caminho inverso. O caminho correto é acordar tanto quanto possível o elemento artístico à formação intelectual. Assim, já nos primeiros anos do ensino, quando a criança nos é confiada, devemos empenhar-nos em proporcionarIhes a escrita e a leitura de forma artística (STEINER, 1995:131-132).

O próprio Steiner considerava não ser possível ensinar a ler e a escrever permanecendo apenas no artístico, pois levaria um tempo muito grande em termos dos anos que seriam necessários para que isto fosse feito. Por isso, por algumas horas diárias seria necessário atuar racionalmente, mas, sempre que possível, retornando ao artístico. É importante dizer às crianças que os adultos descobrem o sentido nas formas que elas estão aprendendo. Não há necessidade de ensinar todas as letras para começar a escrever frases com as crianças. É importante que elas não identifiquem algumas formas e identifiquem outras. Em suas palavras:

(...) um dia escreveremos uma frase longa na lousa, dizendo à criança: "Isto é o que os adultos têm diante de si após terem 
desenvolvido tudo aquilo de que falamos - o f de Fisch, e assim por diante". Então ensinaremos a criança a copiar. Nossa atenção se deterá em fazer com que aquilo que ela vê passe para suas mãos, de modo que ela não apenas leia com os olhos, mas reproduza manualmente, sabendo fazer ela própria, assim ou assim, tudo o que está na lousa. Assim conseguiremos algo extremamente importante: que nunca ocorra uma leitura simplesmente com os olhos, e sim que a atividade ocular passe secretamente para toda a atividade dos membros do homem. Então as crianças sentirão inconscientemente, até pelas pernas adentro, o que de outra forma só perceberiam com os olhos. O interesse do ser humano por inteiro nessa atividade - eis o que deve ser aspirado por nós (STEINER, 2003:15).

Para que o ensino não se torne puramente racional como nas escolas de seu tempo, Steiner aconselhava uma alternância na forma de ensinar a ler e a escrever. Com isto, ele queria dizer que, uma parte do ensino da escrita deveria ser feita do detalhe para o todo, partindo de algumas letras chegando a algumas frases; a outra parte, deveria ser feita de forma contrária, isto é, do todo para o detalhe - partindo dos signos que a criança não identifica ou conhece em uma frase para depois explicá-los individualmente (STEINER, 2003:15).

Com relação à leitura, Steiner considerava que em um ensino ideal, além da exigência da escrita advir do desenho, como foi descrito nos parágrafos anteriores, a leitura das letras impressas deveria advir da leitura do que a própria criança escreveu. Isto faz com que a criança desenvolva um sentimento especial pela linguagem, uma adequada ligação sentimental com a língua. Consequentemente, proporciona uma conscientização futura para a estrutura da linguagem (STEINER, 2003:53).

O que é inerente ao homem é a capacidade de se comunicar por meio da 
fala. Ao passo que a escrita e, por conseguinte, a leitura, devem ser aprendidas. A escrita e a leitura baseiam-se em convenções culturais, fazem parte do plano físico e não têm nenhuma ligação com o plano espiritual. Por isso, são estranhas à criança e só poderão ser incorporadas por ela através do sentir. Como explica Steiner:

Nós lemos, mas a arte da leitura desenvolveu-se no decorrer da evolução cultural. As formas dos caracteres surgidos, a ligação dos caracteres entre si, tudo isso se baseia em convenção. Ao ensinarmos a criança a ler da maneira atual, ensinamo-lhe algo que, na verdade, não tem significado algum para a entidade humana tão logo nos abstraímos da presença do homem em determinada cultura (...). A escrita dos homens formou-se pela atividade, pela convenção dos homens no plano físico (...) trata-se de algo originado dentro do corpo físico (STEINER, 2003:11-12).

A maneira proposta por Steiner de ensinar a ler e a escrever, visa sensibilizar a criança para as diferenças entre os signos. Sensibilizar é atuar no eu e no corpo astral ou corpo das sensações, é atuar no que é espiritual e não apenas físicocorpóreo. A sensação é elevada ao intelecto por meio da utilização das artes plásticas ou da música (STEINER, 2003).

Além do desenho, da pintura e da música, uma parte do período escolar deve ser ocupada com a narração de contos e lendas. Na concepção de Steiner, o professor não deve explicar os contos e as lendas; deve simplesmente narrá-los com emoção, com entonação correta, sem ser artificial. Se explicar, estará atuando conceitualmente e, por conseguinte, atuará apenas na cabeça e não na criança por inteiro. As narrativas atuam na criança por inteiro quando desencadeiam sentimentos e emoções, alegria e dor, quando atuam nos sentimentos e na vontade 
de forma que a criança sente nos membros o que transfere para seu coração e, por último, à cabeça - do sentir ao querer e ao pensar. Por isso, para Steiner:

(...) quando Ihe é contada muita coisa que lhe traz alegria ou dor, isso desenvolve, a partir do âmbito inferior do homem, o corpo astral. Eu acredito que todos os Senhores já tiveram a seguinte experiência: andando pela rua e tendo-se assustado com alguma coisa, assustaram-se não apenas com a cabeça e o coração, mas também com os membros, sentindo neles o susto. Disto os Senhores poderão concluir que a entrega a algo que desencadeia sentimentos $\mathrm{e}$ emoções atinge o homem inteiro, e não apenas o coração e a cabeça (STEINER, 2003:21).

As narrativas devem acompanhar a criança desde o nascimento até o fim da vida escolar. No período compreendido entre os sete e os catorze anos de idade, é importante que os contos sejam narrados de forma livre e narrativa (STEINER, 1999:20).

Dos sete aos doze anos de idade, Steiner considerava não ser necessário mais do que três horas e meia para ocupar a criança na escola. Sendo que este período deveria ser dividido em uma hora e meia de ensino concentrado no qual é necessário o esforço da cabeça, meia hora para a narração de histórias e uma hora e meia para o ensino artístico. Este seria o ideal do ensino e traria disposição às crianças (STEINER, 1999:19).

Atuando desta forma, desenvolve-se a unidade por meio da união do intelectual com o volitivo. Nas palavras de Steiner: "a questão é, portanto, desenvolver uma das unilateralidades: ser educado no campo das ideias; a outra unilateralidade, a plástico-pictórica, vivifica então o que é desenvolvido no mero 
conceito" (STEINER, 2003:36).

Steiner criticou os pedagogos de sua época que consideravam que só devemos ensinar à criança o que ela entende, por considerar que esse princípio desvitaliza qualquer esforço educacional. Para ele, a educação se torna viva quando o conteúdo que a criança recebe permanece num plano subjacente só aflorando posteriormente. Principalmente na fase dos sete aos quinze anos de idade, deve-se incutir na alma infantil coisas que só mais tarde poderão ser compreendidas. Steiner exemplificou isto na seguinte citação:

A criança precisa justamente saber que ela precisa esperar. É este o sentimento que também se pode provocar nela: o de que ela deve esperar pela compreensão do que já agora assimila. Por isso nem era tão ruim que, em tempos mais antigos, as crianças tivessem simplesmente de aprender $1 \times 1=1,2 \times 2=4,3 \times 3=9$, etc., ao invés, de como hoje, aprenderem na máquina calculadora. Esse princípio de reduzir a compreensão da criança deveria ser rompido. Naturalmente isso só pode ocorrer com o necessário tato, pois não nos devemos afastar muito do que a criança é capaz de amar; mas ela pode muito bem assimilar, puramente apoiada na autoridade do professor, muita coisa para a qual sua compreensão só virá mais tarde (STEINER, 2003:39).

No ensino que leva em conta o desenvolvimento do intelecto em paralelo com o desenvolvimento da vontade, o papel desempenhado pela música e pela poesia é fundamental. Para Steiner, o elemento plástico-pictórico individualiza o ser, o faz entrar em contato com seu mundo interior, enquanto o poético-musical fomenta a vida social. Ele definiu o poético-musical como a cadência e o ritmo necessário para a manutenção da rima, que imprimem musicalidade na formulação da linguagem 
poética. Ainda, segundo Steiner, em poetas como Schiller, Lessing ou Goethe, a poesia provém das profundezas da alma. E é para o elemento musical subjacente em cada poesia que se deve direcionar a atenção da criança. Em suas palavras:

Os homens entram em comunhão pelo poético-musical e se individualizam pelo plástico-pictórico. A individualidade é mantida mais pelo plástico-pictórico, e a sociedade mais pela vida e pela trama contidas no musical e no poético. O poético é produzido a partir da solidão da alma, e só dela, vindo a ser compreendido pela comunidade humana. O que se quer fundamentar, ao dizer que com sua criação poética o homem descerra seu interior e que, pela acolhida da criação, algo vem ao encontro desse interior partindo das mais íntimas profundezas do outro, não é uma abstração, e sim algo absolutamente concreto. Por isso a criança em crescimento deveria ser educada para sentir alegria e anseio diante da música e da poesia. No caso da poesia, cedo ela deveria conhecer 0 verdadeiramente poético. Hoje em dia o ser humano cresce numa ordem social onde é tiranizado pela prosa linguística. Existem hoje inúmeros declamadores que tiranizam o ser humano pela prosa, salientando o que numa poesia é prosa, é mero conteúdo. E quando na declamação, a poesia é configurada de modo que a nuance do conteúdo efetivamente desempenha o papel principal, isso é atualmente considerado recitação perfeita. Mas uma recitação realmente perfeita é aquela que realça especialmente o elemento musical (STEINER, 2003:40-41)

Por isso, Steiner considerava inconcebível a explicação gramatical por meio da poesia, hábito comum nas escolas em sua época. O ensino da gramática é importante, porém não deve ser ensinado e explicado utilizando-se a poesia ou textos literários. Após a recitação de uma poesia, após a leitura de um texto literário, após a narração de um conto, nenhuma explicação deve ser dada à criança. Se 
houver necessidade, pode-se preceder a leitura com algumas considerações necessárias para uma compreensão geral, mas nunca esmiuçar o conteúdo a ser narrado.

As explicações devem fazer parte do ensino restante, da parte do ensino que é concentrada e visa ao intelecto. O que é trabalhado na parte conceitual do ensino deve aflorar espontaneamente e propiciar a compreensão do que é literário. De acordo com Steiner, no plástico-pictórico a criança contempla e vivencia a beleza, no musical ela se torna, ela própria, beleza (STEINER, 2003:42-43).

Não foi apenas ao ensino da gramática que Steiner se referiu. Nenhum ensino intelectual, assim como, nenhum comentário, deve ser feito após a leitura de um texto. Desta forma, não se atua sobre os sentimentos e as emoções. O texto em prosa, a poesia, devem atuar sobre a alma da criança causando-lhe uma impressão, satisfação, alegria. Por isso, ele fez o seguinte alerta:

Eu gostaria de alertá-los para nunca arruinarem o conteúdo de um texto de leitura (...) em relação aos sentimentos e emoções, lendo-o para os alunos ou junto com eles e explicando-o em seguida de maneira pedante (...). Não é preciso tecer quaisquer considerações, quaisquer comentários a respeito de uma poesia ou de um texto de leitura; o que se deve é elevar completamente a criança a uma compreensão pelo sentimento. Por esse motivo, procure-se sempre proceder à própria leitura do texto por último, precedendo-a de tudo o que se queira para facilitar a compreensão. Antepondo o procedimento correto, não se age como mestre escolar pedante, e sim se contribui para que nada fique incompreensível no texto. Então o prazer e a satisfação da criança aumentam (STEINER, 1999:60).

No ensino da gramática, na parte conceitual da aula, deve-se elevar a 
linguagem para o âmbito da conscientização da estrutura da própria língua. 0 sentimento da criança pode ser despertado no ensino dos substantivos, dos adjetivos e dos verbos. A criança percebe o mundo exterior por meio dos objetos que ela encontra à sua frente e que são designados por substantivos. Há uma separação entre a criança e o objeto. Esta separação deixa de existir a partir do momento em que a criança atribui uma qualidade ao objeto percebido, pois por meio da qualidade a criança volta a se unir ao objeto. Ao designar o verbo a criança participa tanto da ação quanto percebe a pessoa que executa a ação. Nas palavras de Steiner: "ao pronunciar um substantivo separo-me do mundo, ao pronunciar um adjetivo ligo-me a ele, ao pronunciar um verbo torno-me ativo no mundo ambiente, agindo com ele" (STEINER, 2003:53).

Outra crítica feita por Steiner com relação ao ensino de sua época, diz respeito à importância dada ao estudo na Natureza, isto é, levar as crianças para a natureza e dar-lhe explicações sobre as plantas, o solo, os animais etc. Para ele, o único local apropriado para se dissecar a natureza era a sala de aula. Na sala de aula é possível observar a planta, descrever suas características, falar cientificamente sobre a planta, sobre o solo, sobre os animais. A natureza deve ser contemplada e admirada. Dito por Steiner:

Não deveríamos absolutamente crer que fazemos bem em explicar cientificamente um besouro lá fora, na Natureza. A explicação científica do besouro pertence à sala de aula! Alegria por ver o besouro, por sua maneira de locomover-se, por seu jeito engraçado, por sua relação com o resto da Natureza - eis o que deveríamos provocar ao levar as crianças ao campo (STEINER, 2003:44). 
Não é indicado apresentar definições, conclusões e coisas que a criança deve decorar. Deve-se caracterizar, isto é, apresentar as coisas sob pontos de vista diversos. Jamais dizer: "O elefante é...", mas apresentar o elefante em relação a outros animais, ver as similaridades e diferenças existentes entre eles, compará-los ao homem, ver como os povos os consideram, como é o caso, por exemplo, da veneração ao elefante na Índia. Os conceitos devem ser vivos e devem poder se transformar e desenvolver no decorrer da vida da criança. De acordo com Steiner, o homem deve viver e, portanto, o conceito deve poder "con-viver" (STEINER, 1995:111). Em suas palavras:

O que vive no homem tem a tendência de realmente se transformar de maneira vívida no decorrer do tempo. Se fizermos com que a criança tenha conceitos de devoção, de veneração, conceitos de tudo aquilo que, num sentido abrangente, podemos chamar de disposição para a prece, tal ideia permeada com essa disposição é viva, alcançado até a idade avançada e transformando-se então na capacidade de abençoar, de repartir com outros os resultados dessa disposição (...) Portanto, propiciar tais conceitos relacionados ao mais íntimo do homem significa dotá-lo de conceitos viventes; e o que é vivente assume metamorfoses, transforma-se com a vida do próprio homem (STEINER, 1995:113).

Steiner considerava que essa era a única maneira de se infundir na criança os conceitos morais firmes e não vacilantes, apelando ao sentimento e à vontade, jamais explicando o sentido da moral. Não se pode educar simplesmente com vistas ao sentido. Deve-se educar de acordo com o que a vontade experimenta em seu estado dormente - no elemento rítmico, na cadência, na melodia, na repetição, nas cores, isto é, na atividade em si sem a intervenção consciente do sentido. Ele 
explicou que:

Se os Senhores fizerem a criança repetir frases que ela ainda não compreende devido à sua idade, se as fizerem gravar essas frases na memória, não atuaram sobre seu intelecto por não poderem penetrar no sentido, pois este só deverá desvendar-se mais tarde; mas atuarão sobre sua vontade, e isso é o que precisam e devem fazer (STEINER, 2003:70).

Tudo que é ensinado por meio da arte, da pintura, do desenho, da poesia, etc., deve ter um sentido, porém, este sentido não deve ser compreendido de imediato. Na maturidade este sentido virá à tona e será então compreendido. É desta forma que se atua sobre o querer e, especialmente, sobre o sentir da criança. Assim como o sentir se situa, como atividade mediadora, entre o querer e o pensar, também a atividade educativa que visa ao sentir deve ser mediadora das medidas a serem tomadas em relação ao pensar e das medidas destinadas ao querer e seu desenvolvimento. Segundo Steiner:

Para o conhecimento intelectual, devemos recorrer ao que desvenda o sentido: ler, escrever, etc.; para a ação volitiva precisamos desenvolver tudo o que não se relacione com a mera indicação do sentido, mas com a capacitação imediata do homem todo: o elemento artístico. $O$ que se situa entre ambos atuará preferencialmente sobre o cultivo do sentimento, sobre o cultivo da afetividade. Sobre esse cultivo do sentimento existe uma atuação muito intensa quando a criança é colocada na situação de primeiro assimilar algo de forma puramente mnemônica, sem compreendê-lo - sem que se discorra sobre o sentido, embora este exista -, de modo que após algum tempo, estando ela mais madura devido a outras medidas, lembre-se novamente disso e só agora compreenda 
o que assimilou antes (STEINER, 2003:70).

De acordo com Steiner, a matéria de ensino deve captar, principalmente, as capacidades volitivas, emocionais e intelectuais da criança. Por isso, para ele, é mais importante o desenvolvimento das capacidades anímicas da criança e menos importante o que ela memoriza, ou o ensino que visa exclusivamente o desenvolvimento do raciocínio. Ele considerava que, no futuro, seria necessário educar ao máximo os instintos sociais, a vontade social, o interesse social (STEINER, 1999:40).

A relação professor/aluno é de suma importância na pedagogia proposta por Steiner, visto que o professor é o impulsionador e vivificador do ensino (STEINER, 2003:123).

Pelo que foi exposto nesta seção, já é possível perceber a forma como Steiner valorizava o papel da literatura para a formação da vontade por meio de sua atuação no sentir das crianças em desenvolvimento. A sua concepção sobre a atuação das narrativas na constituição do querer, do sentir e do pensar será apresentada na próxima seção. Está seção será finalizada com uma citação de Steiner que evidencia a sua concepção acerca do valor estético da Literatura:

Tive de vivenciar até mesmo o fato de por exemplo Hamlet, uma pura obra de arte, ter sido explicada, no sentido da gíria teosófica, como isto sendo "Manas", aquilo o "eu" e aquilo outro o "corpo astral". Um personagem é isto, o outro aquilo. Tais "explicações" eram bastante apreciadas. Protestei contra isso porque é um pecado contra a vida humana interpretar simbolicamente o que deve ser acolhido apenas como algo diretamente artístico. Com isso se atribui impertinentemente um "sentido" às coisas, sendo estas trazidas à 
mera consideração onde não deveriam ter lugar (...) ० fato de haver pessoas capazes de interpretar o Hamlet simbolicamente com relação a cada um dos personagens resulta de havermos sido terrivelmente mal-educados, tendo-nos esforçado apenas para sermos educados para o sentido das coisas (STEINER, 2003:69).

\subsection{A ATUAÇÃO DAS NARRATIVAS NO QUERER, NO SENTIR E NO PENSAR}

As crianças são diferentes entre si, algumas se interessam por tudo que está ao seu redor, porém, por um curto período de tempo - o interesse passa de uma coisa à outra sem se deter por muito tempo em cada uma delas. Há crianças que parecem estar imersas em si mesmas, ruminando ideias, cismando interiormente. Apesar de fechadas em si mesmas, não parecem inertes, muito pelo contrário, parecem estar em plena atividade interior, porém, pouco se interessam pelas impressões do mundo exterior. Há também aquelas que estão imersas em si mesmas, porém distraídas, distantes do que se passa no interior e no exterior. $\mathrm{E}$ há, ainda, crianças que estão sempre manifestando e tentando impor sua vontade e, quando isto não é possível, se mostram agressivas (STEINER, 1999:14-15).

De acordo com Steiner, estas diferenças estão relacionadas à predominância de um dos quatro membros constitutivos no homem. No primeiro caso citado, a criança que apresenta interesse momentâneo, porém passageiro pelas coisas exteriores, estamos diante de uma criança em que prevalece o predomínio do corpo astral sobre os demais corpos. No caso da criança que fica cismando imersa e ativamente em seu interior, há o predomínio do corpo físico, ao passo que, na criança imersa distraída e apática em seu interior, há a 
predominância do corpo etérico. Na criança que quer impor sua vontade o tempo todo, há o predomínio do eu.

$\mathrm{Na}$ educação e no ensino, essas diferenças podem ser trabalhadas em conjunto, isto é, reunir crianças com as características descritas no parágrafo anterior em um grupo de estudo ou trabalho, ajudará na obtenção do resultado pretendido - na harmonização visada pela educação e pelo ensino. Com isso é possível intercambiar os interesses de cada criança, fazer com que cada criança aprenda com a outra, se complementem de forma natural (STEINER, 1999:15).

Desta maneira, a educação e o ensino devem partir da maneira de ser de cada criança, respeitando suas características intrínsecas para, a partir do contado com outras crianças, despertar disposições que estão adormecidas. A criança é educada "de alma para alma" (STEINER, 1999:16-18).

Steiner considerava que a vida total da criança compreende três fases distintas: a primeira fase, ou primeiro setenio, é o período do nascimento até a troca dos dentes; a segunda fase, da troca dos dentes até a puberdade, que normalmente ocorre dos sete aos catorze ou quinze anos de idade; e, a terceira fase que é a puberdade. Cada uma destas fases está relacionada à maneira como os quatro corpos constitutivos do ser se adensam e integram a vida terrestre. A integração deve ser facilitada por meio da educação volitiva.

De acordo com Steiner, até os sete anos de idade a criança se relaciona com o mundo por meio da imitação dos adultos e das crianças que vivem ao seu redor e, também, por meio da experiência que ela realiza com os objetos do mundo, enquanto seu corpo físico se desenvolve. Nesta fase, a aprendizagem não se dá por meio da instrução, mas pela imitação. Em suas palavras: 
Até a troca dos dentes, essa evolução impõe que o homem seja preferencialmente um ser imitativo. Ele faz tudo aquilo que observa em seu redor, devendo isso à circunstância de seu espírito da cabeça estar dormindo (...) A criança está com sua parte anímicoespiritual, seu espírito adormecido e sua alma sonhadora, fora da cabeça. Ela se encontra e vive naqueles que estão ao seu redor, e por isso é um ser imitativo. Com isto se desenvolve, a partir da alma que sonha, o amor pelo ambiente, e em especial o amor pelos pais (STEINER, 1995:127).

Na segunda fase, da troca dos dentes até a puberdade, ou dos sete aos quinze anos de idade, segundo Steiner, subjaz inconscientemente a ideia de que o mundo é belo e, em suas palavras: "lidamos com a criança que deseja assimilar com base na autoridade aquilo que deve saber, sentir e querer" (STEINER, 1995:107).

É, especialmente, no primeiro ano escolar que o desenho, a pintura, a música podem atuar como elementos da formação da vontade, vontade que, de acordo com Steiner, ajuda no desenvolvimento da fantasia, da imaginação, que são desencadeadas pelo elemento artístico e promovem alegria e prazer à criança. Vontade que desperta a parte anímico-espiritual da criança que se encontra adormecida. A criança sente o desenvolvimento de seu corpo físico e não consegue despertar seu eu e seu corpo astral. O elemento artístico atua no eu e no corpo astral da criança distraindo-a de seu desenvolvimento físico e ajudando a integrar ao corpóreo seu eu e seu corpo astral.

Ele atribuía o fato de existirem crianças malcriadas no seu tempo, à ênfase exagerada dada nas escolas da sua época ao ensino racional. O ensino cognitivo desvinculado do ensino volitivo, ou do ensino da vontade por meio dos elementos artísticos, não incentiva a fantasia. Não é possível desenvolver a fantasia com o 
ensino de coisas óbvias e com explicações de tudo tim-tim por tim-tim. Não há prazer em um ensino desse tipo. Surge o desinteresse e o desânimo, pois não há espaço para sonhar, para fantasiar. A criança tem a impressão que assimilou tudo e se desliga do que aprendeu na escola. O ensino deve ser vivo, estimulante, deve deixar a criança em suspenso, de forma que ela vá para casa ansiosa por contar a seus pais suas descobertas, tagarelando sobre tudo o que descobriu e aprendeu na escola (STEINER, 2003:143).

A repetição é extremamente importante, nos primeiros anos da criança na escola, pois cultiva o real impulso volitivo. A repetição deve ocorrer de duas formas: consciente e inconscientemente. A repetição consciente de certas ações, certos hábitos simples, ações e hábitos que devem ser executados pela criança com dedicação, com amor é um treino da vontade e da moral que aflorará no homem adulto. Steiner comenta que:

(...) Se o homem moderno tivesse que ler a cada dia a mesma história, ele nem o faria, por isto the parecer muito enfadonho. $\mathrm{O}$ homem moderno é adestrado para ter experiências únicas. Os homens de antes aprenderam não só a rezar todo dia o mesmo Painosso - tinham ainda um livro de contos que liam no mínimo uma vez por semana. Isso os tornou, no que concerne a vontade, mais vigorosos que os homens atuais, frutos da educação moderna; pois o treino da vontade depende da repetição, e da repetição consciente. É isso que se deve levar em conta (STEINER, 1995:63).

É importante, nesta fase, fazer com que a criança repita versinhos, com ritmo e cadência. Não há necessidade de que ela compreenda o sentido; o importante é o prazer despertado com a recitação. 
A criança, no sentido espiritual de Steiner, precisa harmonizar todos os membros constitutivos de sua estrutura anímico-espiritual (eu e corpo astral) à estrutura inferior físico-corpórea (corpo físico e corpo etérico) de que é revestida ao nascer. É dessa forma que Steiner explica como as narrativas ajudam a criança a se sentir por inteiro e a integrar a parte-individual à própria corporalidade.

As narrativas facilitam a integração dos diferentes membros constitutivos do homem. Por isso, Steiner recomenda para o primeiro ano, a narração de contos de fada; no segundo ano, utilizar as fábulas e os contos sobre os animais. Em suas palavras:

Corresponderia ao ideal do ensino o fato de a criança não precisar senão de uma hora e meia por dia para o ensino concentrado, ao qual é necessário o esforço da cabeça. Em seguida poderemos narrar contos de fada durante mais meia hora. Além disso, resta a possibilidade de estruturar em cerca de uma hora e meia o ensino artístico. Para as crianças até doze anos de idade, não precisaríamos de um tempo superior a três horas e meia por dia (STEINER, 1999:19).

O importante para Steiner era apresentar às crianças, no primeiro ano escolar, contos que estimulassem a fantasia. Paralelo à narração dos contos, Steiner considerava importante praticar uma conversação singela com as crianças. Com o tempo, o narrar e o conversar levariam a criança a ser capaz de recontar um conto que foi lido na aula anterior. A repetição do ouvir e depois recontar o que foi ouvido, posteriormente, poderia ser substituída pelo relato da vivência própria da criança. Isto ajuda no desenvolvimento da linguagem culta, conforme explica Steiner: 
Por meio desse narrar, recontar e relatar experiências próprias desenvolveremos, sem pedantismo, a transição do dialeto para a linguagem culta de conversação, simplesmente corrigindo os erros que a criança faz - no início numerosos, mas depois cada vez mais raros. Nós desenvolveremos a criança da linguagem em dialeto para a linguagem culta, por meio da narração e sua reprodução (...) no fim do primeiro ano escolar a criança terá alcançado a meta de ensino que hoje lhe é exigida (STEINER, 2003:135).

Steiner considerava importante refletir sobre o conteúdo a ser ministrado nas aulas de contos, visto que essas aulas seriam ministradas durante toda a vida escolar, dos sete aos catorze anos de idade, de forma livre e narrativa. Por isso, seria necessário dispor de um acervo de contos de fada, um acervo de fábulas e de histórias sobre o reino animal. Os contos de fadas, na concepção de Steiner, atuam na parte espiritual, no eu. E, para ele, é entre o sétimo e o nono ano de idade, que a consciência do eu é fortalecida e adensada.

As fábulas e as histórias sobre os animais ajudam a integrar e incorporar ao eu o corpo astral (ou corpo das sensações) que é o que o homem tem em comum com os animais. Por meio dessas narrativas a criança incorpora sua parte anímicoespiritual.

A partir do décimo ano deve-se sensibilizar a criança sobre o quanto ela é uma síntese da natureza exterior e sobre a relação do ser humano com toda a natureza exterior (STEINER, 2003:89). Lembrando que, o corpo etérico é o que o homem tem em comum com o reino vegetal, nesta fase é oportuno utilizar narrativas que falem sobre a natureza.

É entre o décimo segundo e o décimo terceiro anos de idade que o lado anímico-espiritual da criança se fortalece e intensifica. Nesta fase o corpo astral se 
intensifica e a criança se torna menos dependente do eu. Na concepção de Steiner, é quando inicia a ligação do corpo astral com o corpo etérico. É o momento oportuno para despertar a criança para a compreensão dos impulsos históricos. Para Steiner:

\begin{abstract}
Antes dessa época, podem narrar-Ihe a História contando histórias, biografias. Isso ela captará, mas não relações históricas antes dos doze anos completos. Por isso os Senhores the causarão mal se não observarem esse momento, em que o ser humano começa a desenvolver um anseio de agora receber realmente apresentado como História o que antes acolheu como histórias (...) justamente do mesmo modo como se deve continuar a narração de histórias até os doze anos, para então fazer das histórias "História" (STEINER, 2003:89-91).
\end{abstract}

Tudo que é incutido na criança por meio do sentimento faz com que o resultado letivo permaneça por toda a vida. Isto deve ser levado em conta, principalmente no final do primeiro grau. Nesta fase, tudo o que é puramente intelectual ou racional não tem o poder de permanecer por toda vida. O contrário acontece quando, ao elemento da fantasia se associa o sentimento. Se o ensino da Geografia, da História, das disciplinas em geral, for apresentado de forma visual e apelando-se ao sentimento da criança, este ensino permanecerá por toda a vida (STEINER, 2003:146).

Steiner fez uma crítica aos livros didáticos e a maneira como a história era descrita neles. Ele considerava que da forma como os livros tratavam o ensino em geral, acabavam por aborrecer e tornar o ensino um tédio. Isto por não atuarem adequadamente no subconsciente do jovem. Em suas palavras: 
Se os Senhores refletirem que a compreensão não é algo que simplesmente brota do intelecto humano, mas sempre abrange sentimento e vontade. Pode-se, provisória e imperfeitamente, transmitir ao intelecto do ser humano noções históricas ou fisiológicas antes dos doze anos, mas com isso se deteriora a natureza humana, tornando-a inadequada para toda vida (STEINER, 2003:92).

O mesmo deve ser observado no ensino aos jovens de treze, catorze ou quinze anos. Procurar não tornar o ensino um fardo para o desenvolvimento anímico humano. Isto pode ser obtido por meio de um ensino econômico, isto é, ensinar apenas aquilo que trará frutos para a vida futura do jovem não o sobrecarregando com conceitos que exigem demais da memória e que poderão ser aprendidos posteriormente de acordo com o interesse de cada jovem. A economia é em relação ao intelecto, jamais em relação ao artístico. O artístico não se torna um fardo e desenvolve o sentimento e a vontade por meio da fantasia e da imaginação, por meio do belo (STEINER, 2003:98).

De acordo com Steiner, para facilitar a integração da criança à vida terrestre é recomendável primeiro apresentar os contos de fadas; depois, contos que falem sobre os animais, passando para histórias do reino animal e as fábulas; em seguida, ler história bíblica em conexão com a História Geral (isto se for uma comunidade cristã, se for uma comunidade budistas, hinduístas, maometana ou israelita, convêm procurar outros temas análogos); e, por último, narrativas sobre a natureza, os povos e diferentes culturas, inserindo os conhecimentos etnológicos por meio da História Antiga, Medieval e Moderna. Esta ordem, dos contos de fada aos conhecimentos etnológicos, objetiva integrar a parte espiritual-individual da criança à 
própria corporalidade e à sua adaptação e autonomia futura em sua vida terrestre (STEINER, 1999:20-21).

É possível encontrar na obra de Steiner, exemplos de como trabalhar com as narrativas para se obter a correta integração dos quatro membros constitutivos do ser por meio da educação volitiva (do querer, do sentir e do pensar). Citaremos alguns.

Antes de narrar uma história que tenha como animal um cavalo, por exemplo, pode-se despertar a atenção da criança que tem predominância do corpo etérico e fica inerte dentro de si, perguntando: "Vejam, o que diferencia vocês dos cavalos?" (STEINER, 1999:38-39).

Para a criança que tem predominância do eu e quer sempre impor sua vontade, Steiner contou a seguinte história:

(...) uma criança que encontra um cavalo bem lá longe, na floresta. O cavalo está correndo, e bem mais longe, atrás dele, corre um homem do qual o cavalo está fugindo, e a criança deve pegar o cavalo segurando-o pela rédea (...) [a criança] deve ser induzida a fantasiar como capturar o cavalo, e isso é muito bom (STEINER, 1999:39).

As narrativas podem ser uma via indireta para se corrigir problemas de comportamento. Steiner citou um exemplo sobre uma criança que gostava de inventar mentiras. Nas palavras dele:

Imaginem um caso, uma história, em que uma criança mentirosa é levada até o absurdo ao ser conduzida, por sua própria mentira, a uma situação que ela deve julgar leviana. Quando se conta uma história dessas a ela, e depois mais outra, e outras mais do mesmo 
tipo, via de regra cura-se a criança de seu pendor à mentira (STEINER, 1999:48).

Por meio de narrativas é possível também resolver problemas de relacionamento entre os alunos. Ele citou o caso de um grupo de três crianças a quem ele apelidou de "gatas borralheiras" que era hostilizado por alguns alunos da sala. Neste caso, ele aconselhou aos professores "comporem uma história a ser contada diante de toda a classe, fazendo com que as três ficassem consoladas e as outras um pouco envergonhadas". As narrativas atuam nas crianças de forma a propiciar novas situações sociais, novos encontros baseados na simpatia das crianças (STEINER, 1999:48).

De acordo com Steiner, a punição e o castigo não resolvem as situações, deixando sempre alguma coisa pelo caminho. A punição provoca medo, não provoca sentimentos que conduzam a uma melhora no comportamento. Portanto, ele aconselhava apelar ao sentimento, e não ao julgamento, produzir sentimentos que provocasse um recuo na atitude. Embora, para ele, muitas vezes a indisciplina estava relacionada ao tédio das crianças e a falta de relacionamento adequado com o professor (STEINER, 1999:48,56-57).

Será apresentado na próxima seção alguns contos e poemas utilizados por Steiner na primeira escola Waldorf fundada em Stuttgart no ano de 1919.

\subsection{CONTOS E POESIAS UTILIZADOS POR STEINER EM 1919}

É no livro A Arte da Educação III - Discussões Pedagógicas, que Steiner 
apresenta alguns exemplos de contos e poesias a serem trabalhados com os alunos da primeira escola Waldorf. Este livro é composto por dezenove partes divididas em quinze colóquios, três transcrições de palestras sobre o currículo e algumas considerações finais. Cada parte foi ministrada em um determinado dia no período compreendido entre 21 de agosto e 6 de setembro de 1919. Nos colóquios, a redação intercala a fala de Steiner com falas curtas em forma de pergunta ou considerações dos professores e pessoas interessadas que participaram do seminário.

Entre as poesias, Steiner cita uma estrofe do poema "Zahme Xenien" de Goethe que fala da relação de uma criança com seus pais. Para ele, Goethe estava muito à frente de seu tempo e era conhecedor dos mistérios da vida. Por isso, de acordo com ele, na estrofe escolhida, Goethe salientava a forte atuação do princípio paterno no corpo físico e no eu da criança, e a atuação do elemento materno nos corpos etérico e astral. No livro aparece apenas a tradução para o português. Citaremos a tradução e o original em alemão:

$\begin{array}{ll}\text { De meu pai tenho a estatura } & \text { - referência ao corpo físico } \\ \text { e a séria conduta na vida } & \text { - referência ao eu } \\ \text { de minha mãe a natureza alegre } & \text { - ligada ao corpo etérico } \\ \text { e a vontade de fantasiar } & \text { - ligada ao corpo astral } \\ (\text { STEINER, 1999:52) } & \end{array}$
Vom Vater hab'ich die Statur - was sich auf den physuschen Leib bezieht

Des Lebens ernstes Führen, - was sich auf das Ich beziet

55 Tradução de Jacira Cardoso. 
Vom Mütterchen die Frohnatur Und Lust zu fabulieren
- was an den Ätheleib gebunden ist - was an den Astralleib gebunden ist (STEINER, 1984:53).

Além da poesia de Goethe, Steiner cita um poema de Hoffmann von Fallersleben. O poema é utilizado para exemplificar a importância de falar às crianças sobre as analogias entre a natureza e o ser humano, de forma a vivificar tudo o que está ao redor e que é experimentado por ela. Por isso, ele aconselha aos professores falarem sobre a modéstia e a imodéstia dos homens, sobre a vaidade, depois ler a poesia sem dar mais nenhuma explicação. No livro ele cita a versão em alemão e depois a tradução para o português. Optamos por inverter a ordem na citação:

$\mathrm{Ei}$, o que é que, escondido, aos raios do sol floresce?

São as lindas violetinhas, que no calmo vale crescem.

Mais baixinhas que o musgo, difíceis de descobrir:

nós, crianças, não as vemos ao passear por aqui.

Mas quem é que está erguendo a cabecinha para fora?

Quem murmura tão baixinho, lá no musgo, bem agora?

"Me procurem, me procurem - logo, logo vão me achar!"

$\mathrm{Ei}$, espere, violetinha, ainda vamos te encontrar! $!^{56}$

Ei, was blüht so heimlich am Sonnenstrahl?

Das sind die lieben Veilchen, die blühn im stillen Tal,

Blühen so Heimlich im Moose versteckt,

Drum haben auch wir Kinder kein Veilchen entdeckt.

Und was steckt sein Köpflein still empor?

Was lispelt aus dem Moose so leise, leis' hervor?

56 Tradução de Jacira Cardoso. 
"Suchet, so finder ihr! Suchet mir doch!"

Ei, warte, Veilchen, warte! wir finden dich noch!

(STEINER, 1999:66).

De acordo com Steiner, não devemos apresentar os conhecimentos científicos de imediato. A poesia ajuda a descrever aquilo que encontramos na natureza de forma que a criança consiga estabelecer analogias com as qualidades anímicas humanas. É no campo que a criança descobre a violeta, sem teorizar. Ao ouvir o verso acima citado, a criança interage com a violeta e com os musgos. $\mathrm{Na}$ adolescência, quando receber os conhecimentos científicos referentes às plantas, não serão apenas informações a serem memorizadas, pois o sentido se constituirá, consciente ou inconscientemente, da vivência do contato na infância com a violeta no campo, da narrativa do poema, do sentimento e emoção que ficou impresso na alma desta criança.

É em relação ao verso $A$ Oração (Das Gebet) de Canções da Forca de Christian Morgenstern que Steiner aconselhava o leitor a prestar atenção parcialmente à forma, parcialmente ao conteúdo. No livro, as versões em alemão e em português, aparecem lado a lado. Optamos por apresentá-las na sequência, colocando em primeiro lugar a versão em português:

As corcinhas rezam, à noite,

Quantas vezes? Atenção:

Oito e meia!

Nove e meia!

Dez e meia!

Onze e meia!

Meia-noite! 
As corcinhas rezam, à noite,

preste atenção:

juntam os dedinhos,

essas corcinhas.

Die Rehlein beten zur Nacht,

Hab acht!

Halb neun!

Halb zehn!

Halb elf!

Zwölf!

Die Rehlein beten zur Nacht,

Hab acht!

Sie falten die kleinen Zehlein,

die Rehlein.

(STEINER, 1999:107).

Steiner apresenta também o poema "Uma Segunda Senda" (Wir fanden einen Pfad) de Christian Morgens nas duas versões, primeiro em alemão, depois em português. Citaremos primeiro a versão em português:

Quem da meta nada sabe

não poderá ter caminho;

estará por toda a vida

num círculo, em redemoinho;

e voltando, enfim, ao ponto

de onde havia partido,

a mente da multidão

só terá mais dividido.

Quem nada conhece da meta

pode hoje ainda aprender,

se com todo o seu fervor

a Verdade pretender; 
se ainda não submergiu

nas águas da vaidade,

e se não se embriagou

do tolo vinho da idade.

Então pelas coisas secretas

haverá, pois, de indagar,

e na conquista da Luz

deverá se aventurar.

Quem não sabe procurar

como o faz um pretendente,

sob o fascínio estará

dos sete véus para sempre.

Wer vom Ziel nicht weiss,

kann den Weg nicht haben,

wird im selben Kreis

all sein Leben traben;

kommt an Ende hin,

wo er hergerückt,

hat der Menge Sinn

nur noch mehr zerstückt.

Wer von Ziel nicht kennt,

Kann's doch heut erfahren;

wenn ed ihn nur brennt

nach dem Göttlich-Wahren;

wenn in Eitelkeit

er nicht ganz versunken

und vom Wein der Zeit

nicht bis oben trunken.

Denn zu fragen ist

Nach den stillen Dingen,

und zu wagen ist,

will man Licht erringen; 
wer nicht suchen kann,

wie nur je ein Feier,

bleibt im Trugesbann

siebenfacher Schleier.

(STEINER, 1999:129-130)

Além de Steiner, alguns alunos do curso ministrado por ele e transcrito no livro A Arte da Educação III, narram alguns contos que não são transcritos para o leitor. Juntamente com Steiner, estes professores discutem a atuação de um mesmo conto de forma diferenciada dependendo do temperamento da criança. A maneira de narrá-los pode variar se levarmos em conta as diferenças dos temperamentos colérico, sanguíneo, fleumático e melancólico. São feitas observações sobre o fato das crianças melancólicas não gostarem de histórias tristes; da importância de realizar pausas durante a narração para atrair as crianças sanguíneas; de ser necessário chamar a atenção de uma criança fleumática para determinadas características de um personagem; e de atrair uma criança colérica para um movimento descrito na história, como, por exemplo, a perseguição a um cavalo etc. Entre os contos mencionados estão: A criança de Maria (Das Marienkind), 0 Macaquinho (Das Meerkätzchen), Similiberg, Sésamo (Das Sesammärchen), e uma história que fala do cavalo, do burro e do camelo, embora não haja nenhuma menção sobre o título deste conto. Steiner considera interessante, após a narrativa desta história, perguntar às crianças com qual animal ela mais se identifica.

Há quatro fábulas de Lessing que estão traduzidas para o leitor, e que serão citadas a seguir: O Rouxinol e o Pavão (Die Nachtigall und der Pfau), O Cão Pastor (Der Schäferhund), O Corcel e o Touro (Das Roß und der Stier) e O Carvalho (Die Eiche). 
Antes de narrar O Rouxinol e o Pavão, Steiner observa que textos em prosa podem ser lidos em diversas entonações, de acordo com a preferência e características de quem narra. Ele também sugeriu não dar ênfase ao título, deixando-o passar despercebido. A fábula diz o seguinte:

Um rouxinol sociável encontrou entre os cantores da floresta muitos invejosos, mas nenhum amigo. "Talvez eu o encontre em outra espécie", pensou, e foi ter com o pavão. "Meu belo pavão, como te admiro!" "Eu também a ti, encantador rouxinol!" "Então sejamos amigos", continuou o rouxinol. "Não fiquemos com inveja um do outro; tu és tão agradável ao olho quanto eu ao ouvido". O rouxinol e o pavão tornaram-se amigos.

Kneller e Pope eram melhores amigos do que Pope e Addison ${ }^{57}$. (STEINER, 1999:59).

Eine gesellige Nachtigall fand unter den Sägern des Waldes Neider die Menge, aber keinen Freund. "Vielleicht finde ich inn unter einer anderen Gattung", dachte sie und floh vertraulich zu dem Pfau herab. "Schöner Pfau, ich bewundere dich!" - "Ich dich auch, liebliche Nachtigall". - "So la $\beta$ uns Freund sein", sprach die Nachtigall weiter. "Wir warden uns nicht beneiden dürfen, du bist dem Auge so angenhm, als ich dem Ohre". Die Nachtigall und der Pfau wurden Freund.

Kneller und Pope waren bessere Freund als Pope und Addison. (STEINER, 1984:60).

Para Steiner, um texto em prosa ou uma poesia deve atuar sobre a alma da criança de modo a alegrá-la com as impressões recebidas, a atuar em seus sentimentos e emoções. Mas para obter esta satisfação, é necessário preparar a

\footnotetext{
${ }^{57}$ No livro há uma nota de rodapé explicando que é uma referência ao retratista inglês Godfrey Kneller (16461723) e aos poetas ingleses Alexander Pope (1688-1744) e Joseph Addison (1672-1719).
} 
criança para a narração, dar algumas explicações necessárias à compreensão do texto. Sempre antes da narração, sem emitir qualquer outro comentário após a leitura do texto. Desta forma, a compreensão acontece pelo sentimento e não pela razão. É desta maneira que Steiner exemplifica o trabalho com o texto $O$ Cão Pastor. Ele explica que chamaria a atenção para os diferentes cães que existem no mundo, sobre as diferenças no tamanho, comportamento, sobre os cães que ficam na porta do açougue guardando a carne. Em seguida, ele compararia o cachorro do açougueiro a um homem que deve guardar e proteger alguma coisa. Nesta comparação ele explicaria às crianças que o que os animais fazem por instinto, os homens fazem por dever, estabelecendo assim analogias entre os homens e os animais. Só, então, narraria a história:

Um velho cão pastor, guardião fiel do rebanho de seu dono, voltava à noite para casa. $\mathrm{Na}$ rua, os cachorrinhos de colo começaram a latir em sua direção. Ele continuou andando e nem olhou para eles. Ao chegar diante do açougue, um cão de açougueiro perguntou-lhe como ele pudera aguentar o latido e por que não agarra um deles pelo colarinho. "Não", disse o cão pastor, "nenhum deles me mordeu, e eu preciso guardar os meus dentes para lutar com os lobos" (STEINER, 1999:63-64).

Ein alter Hirtenhund, der seines Hern Vieh treulich bewachte, ging abends heim. Da kläfften ihn die Polsterhündchen auf der Gasse an. Er trabt vor sich hin und sieht sich nicht um. Als er vor dir Fleischbank kommt, fragt ihn ein Fleischerhund, wie er das Gebell leiden könne, und warum er nicht einen beim Kamm nehme. "Nein", sagte der Hirtenbund,"es zwackt und beißt mich já keiner, ich um $\beta$ meine Zähne für die Wölfe haben" (STEINER, 1984:65). 
Steiner narra a fábula $O$ Corcel e o Touro, e comenta que, como a maioria dos textos escritos no século XVIII, tem-se a impressão de que não foram terminadas:

Sobre um fogoso corcel vinha voando, altivo, um soberbo rapaz. Eis que um touro bravio bradou ao corcel: "Que vergonha! Eu nunca me deixaria conduzir por um menino!" "Mas eu sim", respondeu o cavalo, "pois que gloria me poderia trazer o fato de eu atirar um rapazinho longe?" (STEINER, 1999:71).

Auf einem feurigen Rosse flog stolz ein dreister Knabe daher. Da rief ein wilder Stier dem Rosse zu: "Schande! Von einem Knaben lie $\beta$ ich mich nicht regieren!" "Abe rich", versetzte das Roß, "denn was für Ehre könnte es mir brigen, einen Knaben abzuwerfen?" (STEINER, 1984:73).

Além disso, ele acrescenta um final que poderia ser pertinente ao século $X X$, que é uma crítica aos homens da sua época: "Glória aos touros! E se eu procurasse a glória permanecendo obstinadamente parado, não se trataria da honra de um cavalo, mas da honra de um burro" (STEINER, 1999:71) [Stierehre! Und suchte ich die Ehre, indem ich störrisch stehen bliebe, so ware das nicht Pferdeehre, sondern Eselsehre] (STEINER, 1984:73). E complementa dizendo:

É assim que se procederia na época atual. Então as crianças logo perceberiam que existem três honras: a do touro, a do cavalo e a do burro. O touro atira o cavaleiro longe, o cavalo continua a carregar tranquilamente o jovem, porque é cavalheiresco, e o burro fica emperrado por ver nisso sua honra (STEINER, 1999:71).

Steiner considerava que as fábulas podiam ser lidas realisticamente por se 
desenrolar em um mundo específico, no mundo das fábulas, poesias nunca. Mas ele não explica melhor esta afirmação. Isto é dito após a leitura da fábula $O$ carvalho, e de uma discussão com os participantes do seminário sobre a moral da fábula. Entre as conclusões morais aparecem duas ideias básicas: primeiro, que só na morte se percebe a grandeza de uma pessoa; segundo, que um pequeno só nota o que é grande quando este é derrubado. Porém, para Steiner, o principal é o fato de, apesar da raposa ser descrita como um animal astuto, ela não alcança a majestade da árvore. A raposa sempre andou ao redor do tronco do carvalho, sem jamais ter olhado para cima, por isso não sabia o tamanho daquele carvalho. Mais uma vez, o que importa é a analogia, neste caso, entre o animal e a natureza. A fábula diz o seguinte:

O furioso vento do norte havia demonstrado sua força, numa noite tempestuosa, contra um majestoso carvalho. Agora ele jazia estendido no solo e, embaixo dele, uma quantidade de arbustos esmagados. Uma raposa, cuja toca se achava não longe dali, avistou-o na manhã seguinte. "Que árvore!, exclamou. "Eu nunca pensei que fosse tão alta!" (STEINER, 1999:85).

Der rasende Nordwind hatte seine Stärke in einer stürmischen Nacht an einer erhaben Eiche bewiessen. Nun lag sie gestreckt und eine Menge niedriger Sträuche lagen unter ihr zerschmettert. Ein Fuchs, der seine Grube nicht weit davon hatte, sah sie des Morgens darauf. "Was für ein Baum!" rief er. "Hätte ich doch nimmermehr gedacht, da $\beta$ er so groß gewessen ware!" (STEINER, 1984:89).

Como foi dito na seção anterior, as narrativas podem ser uma via indireta para se corrigir problemas de comportamento. Ao invés de repreender a criança, ou aconselhá-la, basta ler uma história que se relacione com o comportamento 
indesejável que se deseja modificar. É a própria criança, por meio do sentimento e emoção que sente ao ouvir a história, que irá perceber sozinha a lição a ser apreendida. Ao refletir sobre como lidar com os "santinhos", os "bem comportados", Steiner sugeriu contar a história de como o burro adquiriu suas orelhas, que é um conto húngaro de Oskar Dähnhardt intitulado "Por que o burro tem orelhas compridas". A história aparece em uma nota de rodapé na edição em português, é mencionada na edição alemã, porém não aparece transcrita. A história diz o seguinte:

Quando Deus criou o mundo, reuniu todos os animais e deu a cada um seu nome. "Deves chamar-te cavalo, tu lobo, tu urso, tu raposa", disse-Ihes ele. Depois aconselhou-os a voltar no dia seguinte para comprovar que não haviam esquecido seus nomes. O burro era, naquela época, um animal bonito e gracioso - nada de orelhas compridas -, e Deus, tendo lhe dado um dos nomes mais bonitos, dissera que não o esquecesse. Quando, no dia seguinte, os animais se reuniram, cada qual foi capaz de dizer seu nome - menos o burro, que o havia esquecido. Com isso Deus ficou muito zangado e, pegando ambas as orelhas do animal, esticou-as um bom tanto no comprimento e disse: "Burro que tu és, para esqueceres tão depressa!". Desde então o coitado continuou sendo um burro e manteve suas compridas orelhas (N.E. orig.) (STEINER, 1999:67) ${ }^{58}$.

Com relação à História Bíblica, Steiner recomenda a leitura do Evangelho de João para crianças melancólicas - por seu aprofundamento espiritual; a leitura do Evangelho de Mateus para crianças fleumáticas - por sua variedade; a leitura do Evangelho de Lucas para crianças sanguíneas - por sua interioridade; e, por fim, a 
leitura do Evangelho de Marcos às crianças coléricas - por sua energia (STEINER, 1999:26).

Além das indicações dos contos e poesias acima citados, Steiner apresenta também exercícios destinados a tornar o fôlego mais prolongado, exercícios fonéticos e exercícios para dicção. No livro são apresentados os exercícios originais, porém sem mencionar a fonte, e a adaptação foneticamente aproximada para o português com o nome do tradutor responsável.

Um exemplo de exercício destinado a tornar o fôlego mais prolongado, apresentado por Steiner e adaptado para o português por Jacira Cardoso é:

$\begin{array}{ll}\text { Erfüllung geht } & \text { Efêmera Fênix } \\ \text { Durch Hoffnung } & \text { Refulge } \\ \text { Geht durch Sehnen } & \text { Em leves nuvens } \\ \text { Durch Wollen } & \text { Em vagos vórtices } \\ \text { Wollen weht } & \text { Vultos veem } \\ \text { Im Webenden } & \text { Veementemente } \\ \text { Weht im Bebenden } & \text { Veem mentes } \\ \text { Webt bebend } & \text { Aprendem } \\ \text { Webend bindend } & \text { Aprendem lindos } \\ \text { Im Finden } & \text { Infindos } \\ \text { Findend windend } & \text { Fins de mundos } \\ \text { Kündend } & \text { Imensos (STEINER, 1999:70). }\end{array}$

Um exemplo de exercício fonético, citado por Steiner e adaptado por Matthias Murbach é:

In den unermesslich weiten Räumen,

in den endenlosen Zeiten,

in der Menschenseele Tiefen, 
in der Weltenoffenbarung:

suche des grossen Rätsels Lösung.

No imenso espaço do universo,

No correr dos tempos infinitos,

No profundo íntimo da alma,

Na revelação do mundo,

Busca a solução do grande enigma (STEINER, 1999:84).

Steiner explica que neste exercício, as quatro primeiras linhas "soam como uma expectativa e a última linha é como que uma realização global das quatro iniciais". (STEINER, 1999:84).

Um exemplo de exercício de dicção citado por Steiner e adaptado por Jacira Cardoso é:

Schlinge Schlange geschwinde

Gewundene Fundewecken weg

Gewundene Fundewecken

Geschwinde schlinge Schlange weg

Marsch schmachtender

Klappriger Racker

Krackle plappernd linkisch

Flink von vorne fort

Krackle plappernd linkisch

Flink von vorne fort

Marsch schmachtender

Klappriger Racker

Chilro chilrante cochicha

Refunde furta-cores réstias

Refunde furta-cores

Cochicha chilro chilrantes réstias 
Marcha majestática

Clávula lépida

Claque plácida lícita

Fímbria fórmica forte

Claque plácida lícita

Fímbria fórmica forte

Marcha majestática

Clávula lépida $\quad$ (STEINER, 1999:162).

Estes são alguns exemplos de contos, poesias e exercícios propostos por Steiner. Há outras indicações que serão apresentadas no capítulo 3 em que não é possível estabelecer se houve, ou não, a participação de Steiner ou apenas de seus seguidores. 


\section{STEINER EM DIÁLOGO COM OUTROS PENSADORES: UMA COMPARAÇÃO}

Este capítulo apresenta as principais mudanças ocorridas no pensamento científico da época de Steiner até o nosso século, estabelecendo uma comparação com as concepções defendidas por Edgar Morin com relação ao Eu, ao pensar e ao sentir. Em seguida, estabelece um paralelo entre as ideias de Steiner e de Walter Benjamin com relação à criança e às narrativas. Finaliza com a apresentação de duas obras distintas, publicadas muitos anos após a morte de Steiner, com exemplos de narrativas utilizadas nas escolas Waldorf da atualidade.

\subsection{AS MUDANÇAS NO PENSAMENTO CIENTÍFICO}

Rudolf Steiner viveu e produziu suas obras no final dos chamados Tempos Modernos, mais especificamente, na Era Romântica (século XIX e primeiros anos do século XX). Já no final do século XIX, alguns pensadores relutavam em aceitar o rumo que a ciência dessa época adotava.

Em linhas gerais, de acordo com os estudos da Filosofia, o século XVIII é marcado pela filosofia da arte e da estética. Até então, não havia uma diferenciação entre o saber e a ciência em geral. Arte e ciência eram tratadas indistintamente por poetas, oradores, filósofos, religiosos, entre outros. Porém, com o desenvolvimento 
da ciência (indutiva e experimental), com a industrialização e a progressiva valorização da técnica, há uma cisão entre os conhecimentos representados pela ciência e os conhecimentos representados pela arte. Inicia-se, assim, a discussão sobre quais são os valores da ciência e quais são os valores da arte, os valores estéticos. Inicia-se, assim, a compartimentação dos saberes.

A cisão entre arte e ciência, embora importante para o desenvolvimento futuro de várias áreas, como é o caso da Literatura, transformava o homem pela razão, pela técnica, pela materialidade do mundo e pela importância atribuída ao conhecimento racional e ao materialismo.

Steiner está entre os pensadores que se opuseram a este pensamento. Estes estudiosos clamavam pelo belo, pela arte, pelo conhecimento embasado no "espírito", pelo que a Natureza oferecia ao homem sem uma explicação possível de causa e efeito. Clamavam pela concepção de ser moral e "espiritual" que na convivência com o mundo e com os outros homens pudesse tornar-se um homem integral e harmônico. Eles opunham o homem do fazer, o "Homo faber", ao "ser" ou homem de "alma bela". Criticavam a maneira como as ideias de sua época contribuíam para a formação desse homem materialista, egoísta, fragmentado e confuso.

Um dos temas desenvolvidos na pedagogia alemã desta época, de acordo com Franco Cambi59, é a reflexão em torno da Bildung, que é um modelo de formação humana e cultural, que visa, sobretudo, a harmonia do sujeito, a sua liberdade-equilíbrio interior e contrapõe ao cidadão e ao Homo faber contemporâneo a utopia da "alma bela". A Bildung é tensão espiritual do eu, contato profundo com as

\footnotetext{
59 Franco Cambi é professor de Pedagogia Geral na Universidade de Florença, onde leciona Filosofia da Educação, História da Pedagogia e Estratégias formativas da comunicação.
} 
várias esferas da cultura e consciência de um crescimento interior para formas de personalidades cada vez mais complexas e harmônicas (CAMBI, 1999:412).

Cambi destaca que, nessa época, além do tema da Bildung, enfatizava-se a função educativa da arte por considerarem que "através da arte se reforça a fantasia, desenvolvem-se as capacidades cognitivas, enriquece-se a personalidade da criança e do jovem" (CAMBI, 1999:412).

Embora haja um preconceito muito grande com relação às ideias de Rudolf Steiner, ao considerar as concepções vigentes na época em que ele viveu, é fácil compreender melhor seu pensamento. Como homem de seu tempo, Steiner foi fortemente influenciado pelo espiritualismo vigente na Europa dessa época, ligandose a temas do Ocultismo e a preceitos da Teosofia que fizeram com que suas ideias fossem rejeitadas. Ele também foi acusado de ter favorecido demais o lado alemão na época da Primeira Guerra. Além disso, a ênfase dada à educação respeitando os temperamentos, que também era um tema recorrente naquela época e que depois foram descartados como estudos válidos, foi outro fator para a rejeição à sua pedagogia. Porém, sua formação foi bastante eclética o que justifica a revisão de suas ideias à luz do pensamento contemporâneo independente de tendências assumidas por ele naquele momento histórico.

Outro fato que deve ser levado em conta para o resgate de suas ideias é a existência concreta de Escolas Waldorf em pleno funcionamento em diferentes países ao redor do mundo, noventa e cinco anos após a fundação da primeira escola por Rudolf Steiner, em 1919. Fato que justifica o resgate das concepções de Steiner com relação à importância da arte para as representações (para as imagens) que formamos no decorrer de nossas vidas, por meio da atuação do sentir no querer e 
no pensar, atuação responsável por nossas ações futuras, pela constituição dos nossos atos da vontade.

\subsection{O EU E O PENSAR EM RUDOLF STEINER E EM EDGAR MORIN}

Edgar Morin (1921-) escreveu, em 2007, que "O homem permanece 'esse desconhecido', hoje, mais por mal ciência do que por ignorância. Daí o paradoxo: quanto mais conhecemos, menos compreendemos o ser humano" (MORIN, 2007:16). Esta citação foi utilizada por ele como crítica aos saberes compartimentados das ciências, aos princípios de redução e separação que imperaram no século XIX, que impedem que se pense o humano tornando as ciências inumanas. Para Morin:

Precisamos de um pensamento que tente juntar e organizar os componentes (biológicos, culturais, sociais, individuais) da complexidade humana e injetar as contribuições científicas na antropologia, no sentido do pensamento alemão do século XIX (reflexão filosófica centrada no ser humano). Significa ao mesmo tempo, reaprender a concepção de "homem genérico", do jovem Marx, que perpassa toda a sua obra, mas complexificando e aprofundando essa noção, à qual faltava o ser corporal, a psique, o nascimento, a morte, a juventude, a velhice, a mulher, o sexo, a agressão, o amor. Precisamos, nesse sentido, de uma abordagem existencial aberta à angústia, ao gozo, à dor, ao êxtase (MORIN, 2007:17).

Morin recorre ao pensamento vigente na época e no local em que Steiner produziu suas obras e defende a reflexão filosófica centrada no ser humano que é a 
base das concepções de Steiner. Vivendo em épocas e locais distintos, ambos se opuseram a cisão entre Arte e Ciência, que gerou nos estudos científicos a dissociação entre sentimento e razão. Segundo Morin:

Meu empreendimento é concebido como interrogação reflexiva dos diversos saberes relativos ao ser humano. Não se trata de somá-los, mas de ligá-los, articulá-los e interpretá-los. Não se quer limitar o conhecimento do humano somente às ciências. A literatura, a poesia e as artes não são apenas meios de expressão estética, mas também meios de conhecimentos (MORIN, 2007:17).

Morin conclui que "o conhecimento do humano deve ser, ao mesmo tempo, muito mais científico, muito mais filosófico, muito mais poético do que é" (MORIN, 2007:18). Além disso, ele considera que um dos pontos de complexidade para a compreensão do humano é o reconhecimento de que o sujeito humano está incluído no objeto. E explica que:

O indivíduo humano pode dispor da consciência de si, capacidade de se considerar como objeto sem deixar de ser sujeito. O pleno desenvolvimento do pensamento comporta a sua própria reflexibilidade: a consciência pode atuar sobre o ser humano refletindo sobre si mesmo, ou atuar sobre o próprio conhecimento, tornando-se conhecimento do conhecimento (MORIN, 2007:39).

Para Steiner, como foi mencionado no capítulo 2, enquanto o homem observa um objeto, este se manifesta como se lhe fosse dado; enquanto pensa, percebe-se a si mesmo como um ser ativo. E ele complementa: 
Considera o objeto como objeto e a si mesmo como sujeito pensante. Pelo fato de aplicar seu pensar à observação, tem consciência dos objetos; pelo fato de aplicá-lo a si mesmo, tem consciência de si mesmo. E porque é consciência pensante, a consciência humana é, ao mesmo tempo, e necessariamente "consciência de si mesmo". Com efeito, o pensar, ao dirigir sua atenção à sua própria atividade, converte em objeto o próprio sujeito, isto é, sua essência primordial (STEINER, 1979:49).

De acordo com Morin:

Pelo pensamento, a inteligência humana questiona e problematiza, encontra soluções, inventa, é capaz de criar. A consciência é a mais extraordinária emergência da mente humana. Produto/produtora de uma atividade reflexiva do espírito sobre si mesmo, sobre as suas ideias, sobre os seus pensamentos, a consciência se confunde com essa reflexibilidade ativa. (...) A inteligência, nas suas múltiplas formas, o engegno, o pensamento, a consciência, a alma, são formas diversas de uma atividade polifônica do espírito. Aqui aparecem separadas, mas não aceitam a disjunção (MORIN, 2007:39).

Já em 1886, no livro Linhas Básicas para uma Teoria do Conhecimento na Cosmovisão de Goethe, Steiner defendia a ideia de que o conhecimento humano deveria ser entendido como uma atividade do espírito humano. Para ele, o homem é uma entidade espiritual una com o cosmo, formado por um Eu portador do espírito e da alma, que ao se defrontar com o mundo e com coisas do mundo, ao objetivar o mundo, distancia-se de sua unidade. A partir daí, passa a experimentar uma dupla natureza: eu e o mundo (interior e exterior). E é justamente a sensação da perda da unidade que impulsiona o homem a buscar as explicações para os fatos e acontecimentos. Segundo Morin: 
Somos filhos do cosmo, mas em função da nossa própria humanidade, de nossa cultura, de nosso espírito, de nossa consciência, de nossa alma, tornamo-nos estranhos a esse cosmo, do qual somos oriundos e que, continua a ser para nós secretamente íntimo. Nosso pensamento e nossa consciência que nos fazem conhecer o mundo físico, também nos afastam dele. O próprio fato de considerar de modo objetivo o universo nos separa dele (MORIN, 2007:48)

Sentimo-nos uno e diversos ao mesmo tempo. E, ainda segundo Morin, "cada indivíduo carrega e sente, em sua subjetividade única, singular anatômica, fisiológica, imunológica, psíquica, afetiva" (MORIN, 2007:75). Para ele é necessário conceber, inseparavelmente, a unidade e a diversidade humanas. Ele diz que:

Ser sujeito supõe um indivíduo, mas a noção de indivíduo só ganha sentido ao comportar a noção de sujeito. A definição primeira de sujeito deve ser bio-lógica. Trata-se de uma lógica de autoafirmação do indivíduo vivo, pela ocupação do centro do seu mundo, o que corresponde literalmente à noção de egocentrismo. Ser sujeito implica situar-se no centro do mundo para conhecer e agir. (...) Assim, a diferenciação decisiva, em relação a outro, não está, antes de tudo, na singularidade genética, anatômica, psicológica, afetiva, mas na ocupação do espaço egocêntrico por um Eu que unifica, integra, absorve e centraliza cerebral, mental e afetivamente as experiências de uma vida. Nenhum outro indivíduo pode dizer Eu em meu lugar, mas todos os outros podem dizer Eu individualmente. Como cada indivíduo vive e experimenta-se como sujeito, essa unicidade singular é a coisa humana mais universalmente partilhada. Ser sujeito faz de nós seres únicos, mas essa unicidade é o aspecto mais em comum (Morin, 2007:74-75).

Há mais semelhanças do que diferenças entre o Eu (anímico-espiritual) de 
Steiner e o Eu de Edgar Morin. Podemos perceber isso na seguinte citação:

O indivíduo não tem identidade física estável; as suas moléculas degradam-se e são substituídas por outras; as células morrem e outras nascem várias vezes na maioria dos tecidos ou órgãos; mas a identidade do seu Eu permanece. Tão diferente ao longo do tempo que um estranho não saberia identificá-lo em fotografias, o Eu permanece ele mesmo através das transformações da criança em adolescente, deste em adulto, do adulto em velho; a qualidade do sujeito transcende as mudanças do ser individual (MORIN, 2007:75).

A teoria da complexidade proposta por Morin, no século XXI, como ele mesmo afirma, "dá novamente sentido às palavras perdidas e esvaziadas nas ciências, inclusive cognitivas: alma, espírito, pensamento" (MORIN, 2007:19). E é no pensamento alemão do século XIX que ele propõe buscar este entendimento.

Há três ideias principais, presentes nas concepções de Steiner apresentadas no capítulo dois, que serviram de base para as proposições apresentadas no decorrer desta pesquisa.

A primeira delas, é a concepção do pensar/intuir e do perceber/observar. Para Steiner, o perceber ativa o pensar, em um movimento de afastamento e aproximação entre o que existe fora, no mundo exterior, e o que existe "dentro", no mundo interior, de cada ser. E é neste movimento de afastamento e aproximação entre os dois mundos, nesta relação que se estabelece entre os dois mundos, entre observar e intuir, ou entre perceber e pensar, que surgem as representações do mundo, as imagens que formamos do mundo e de nós mesmos. Portanto, são as representações mentais que conferem a vida conceitual uma nota individual, já que se relacionam com os sentimentos individuais de cada ser humano, com as 
sensações de prazer ou desagrado que as coisas do mundo provocam em cada ser.

O pensar abarca, ao mesmo tempo, o subjetivo e o objetivo, e nos comunica a realidade total na união que realiza entre a percepção e o conceito. Não é o conceito abstrato que contém a realidade, mas sim a observação pensante, que não considera por si sós nem o conceito nem a percepção, mas a união de ambos (STEINER, 1979:193-197). De acordo com Morin, "todo conhecimento, toda percepção, ideal ou teórica, é, ao mesmo tempo, uma tradução e uma reconstrução" (MORIN, 2007:96), portanto, uma representação.

A segunda ideia a ser resgatada está relacionada à crítica feita por Steiner aos pedagogos da sua época e, mais especificamente, ao ensino puramente racional e intelectual. Ensino que, para ele, não atuava no ser humano por inteiro, desprezando sua constituição físico-corpórea e, principalmente, sua constituição anímico-espiritual. Provém daí a ideia de Steiner de que a pedagogia não poderia ser uma ciência, deveria ser uma arte, pois, por meio da arte, é possível permear o homem por um querer imbuído de sentimento e um sentir imbuído de vontade, ou seja, por meio da arte é possível permear o homem por inteiro. Em outras palavras, a educação intelectual visa ao que é morto no homem, ao que é material e não espiritual. A educação intelectual é vontade envelhecida que impede o desenvolvimento do homem integral, uno, harmônico, pois não atua sobre o sentimento, que é vontade viva ainda dormente (Steiner, 1995:62). Para Morin:

O pensamento estabelece uma dialógica entre o racional e o empírico, o lógico e o analógico, o racional e o mítico, o preciso e o vago, a certeza e a incerteza, a intenção e a ação, os fins e os meios. Por trás dessas dialógicas, há a dúvida, a vontade, a imaginação, o sentimento, a angústia diante dos mistérios do mundo. 
O pensamento, portanto, implica todo o ser (MORIN, 2007:103).

Para Steiner, a vontade do homem não é determinada por circunstâncias externas. Ela é determinada pela mediação do sentir no querer e no pensar. Em suas palavras: "Im Wollen wird die Freiheit geübt; im Fühlen wird sie erlebt; im Denken wird sie erkannt." (no querer a liberdade é praticada; no sentir ela é experimentada; no pensar ela é conhecida) (STEINER, 1985:178) [grifos do autor]. De acordo com Morin:

A afetividade intervém no desenvolvimento e nas manifestações de inteligência. O matemático é movido pela paixão, que intervém também nos espaços de cegueira da inteligência. Anima ou extravia o pensamento; estimula ou obscurece a consciência (...) Há relação, ao mesmo tempo, complementar e antagônica entre nossas duas fontes de realidade, a racional e a afetiva (MORIN, 2007:121-122).

A terceira ideia a ser resgatada das concepções de Steiner é a importância da utilização da narração de contos e lendas durante toda a vida escolar da criança. Justamente por atuarem na criança por inteiro, desencadeando sentimentos e emoções, alegria e dor, atuando nos sentimentos e na vontade de forma que a criança sente em seus membros o que transfere para seu coração e, por último, à cabeça - do sentir ao querer e ao pensar. Como foi dito por ele, "a compaixão só se manifesta no meu coração quando se apresenta à minha consciência, de antemão, a imagem (a representação) de alguém que provoque esse sentimento". Ou ainda, "o amor baseia-se nas imagens que formamos do ser amado, e quanto mais ideais forem estas imagens, tanto mais sublime é o amor" (STEINER, 1979:22-23). 
A criança, no sentido espiritual de Steiner, precisa harmonizar todos os membros constitutivos de sua estrutura anímico-espiritual (eu e corpo astral) à estrutura inferior físico-corpórea (corpo etérico e corpo físico) de que é revestida ao nascer. É desta forma que Steiner explica como as narrativas ajudam a criança a se sentir por inteiro e a integrar a parte-individual à própria corporalidade.

A importância dada por Steiner às narrativas, está diretamente relacionada com o contexto da época em que ele viveu. Lembrando que a literatura passa a ser considerada como uma forma particular de conhecimento a partir da segunda metade do século XVIII. É nessa época que, de acordo com Aguiar e Silva, a literatura passa a ser definida como "um específico fenômeno estético, específica forma de produção, de expressão e de comunicação artísticas (SILVA, 2002:6). É quando a palavra Literatura adquire os significados fundamentais de arte particular, de específica categoria de criação artística e de um conjunto de textos resultantes desta atividade criadora, que apresenta até os dias de hoje (SILVA, 2002:10).

São as transformações ocorridas na sociedade que irão afetar profundamente toda a produção literária a partir do início do século XVIII. A ascensão da burguesia, que se torna cada vez mais poderosa e influente, e o progressivo acesso dessa classe à esfera da cultura, operam uma mudança significativa no gosto vigente que irá se refletir nos textos, nas obras literárias, na música e nos costumes e será responsável pelo desenvolvimento da imprensa e da indústria livreira. Nas palavras de Franco Cambi:

O século XVIII é o século dos jornais e das revistas, da imprensa para mulheres; é o século do romance, das enciclopédias e dos panfletos; é o século em que a imprensa começa a forjar a sociedade 
no seu conjunto, organizando a opinião pública, sobretudo dos grupos burgueses. Os catálogos dos editores se enriquecem, se articulam por temas, por setores, segundo os leitores; as livrarias se tornam locais de encontro, de intercâmbio de ideias, de confronto inclusive político; a difusão dos livros ocorre também através de um mercado clandestino, que procura fugir às proibições da censura, que atingem as obras mais originais e inovadoras (...); a leitura tornase um momento - e central - da vida burguesa, necessário e insubstituível, para nutrir a mente com ideias e o imaginário com novos mitos e novos ideais ( CAMBI,1999:373).

E é a importância dada à leitura pela classe burguesa que irá impulsionar a produção de livros infantis. Considerando que, até o século XVII, a criança era vista como um adulto em miniatura. Não havia a divisão por faixa etária, nem a preocupação com uma formação específica própria às crianças. Os filhos das classes dominantes liam o que seus pais e preceptores liam; os filhos das classes populares eram analfabetos e recebiam a tradição de seu povo por meio da oralidade.

Em meados do século XVIII, com a ascensão da burguesia, surge a preocupação dessa classe com a formação de seus filhos. Inicia-se, assim, uma adaptação dos clássicos da literatura e a produção de textos que pudessem transmitir valores morais às crianças. Talvez tenha sido esse fato que impulsionou os irmãos Grimm em suas pesquisas sobre o nacional-popular, impulsionando-os a buscar diretamente da memória popular as antigas narrativas, lendas ou sagas germânicas que foram conservadas pela tradição oral.

De acordo com Philippe Ariès ${ }^{60}$, a partir do século XVII, o cuidado com a

\footnotetext{
${ }^{60}$ Philippe Ariès (1914-1984) nasceu em Bloís - Paris. Foi um importante historiador e medievalista francês da família e infância. Escreveu vários livros, entre eles A história social da criança e da família. Neste livro, ele
} 
criança passa a inspirar sentimentos novos. A família passa a assumir "uma função moral e espiritual, passando a formar os corpos e as almas" (ARIÈS, 1978:194). A partir do século XIX, a infância passa a ser reconhecida como um período radicalmente diferente em relação ao adulto e passam a levar em conta a complexidade dos processos evolutivo, emotivo e cognitivo da criança (ARIÈS, 1978:194).

Mais uma vez, é o contexto histórico vivenciado por Steiner que impulsiona suas ideias com relação à formação das crianças e a importância das narrativas neste processo. Porém, é importante destacar a originalidade de suas concepções e o fato da prática da narração de estórias, no decorrer de toda a vida escolar, estar vivo até hoje em todas as Escolas Waldorf ao redor do mundo.

\subsection{CRIANÇA E NARRATIVAS EM RUDOLF STEINER E EM WALTER BENJAMIN}

Walter Benjamin ${ }^{61}$ viveu e produziu suas obras na mesma época, no mesmo contexto e no mesmo local que Steiner, na Alemanha. Embora não haja nenhum indício de contato entre eles, ambos enfatizam a importância da trajetória da alma e dos estágios terrenos de sua evolução na formação do ser humano integral. Como pode ser comprovado na seguinte citação de Benjamin:

demonstra que o surgimento de um discurso sobre a infância está vinculado à emergência da percepção da especificidade do infantil na modernidade.

${ }^{61}$ Walter Benjamin nasceu em Berlin em 15 de julho de 1892 onde viveu até 1933, quando teve que fugir por conta da perseguição aos judeus. De 1933 a 1940 viveu como nômade em várias cidadezinhas da França. Em 1940, com o crescimento do nazismo tentou fugir para a Espanha, mas não conseguiu. Suicidou-se em 27 de setembro de 1940 em uma cidade próxima a fronteira com a Espanha. 
Todo indivíduo atuante aspira pela totalidade, e o valor do desempenho individual reside precisamente nessa totalidade; ou seja, no fato de que a essência total e indivisível de um ser humano possa ganhar expressão. Mas a realização socialmente fundamentada, tal como hoje a encontramos, não contém a totalidade, é algo inteiramente fragmentado e derivado (BENJAMIN, 2009:35).

Para Benjamin, todas as manifestações na vida infantil não pretendiam outra coisa senão conservar em si os sentimentos essenciais (BENJAMIN, 2009:50).

Ele fez uma crítica ao preconceito moderno que, ao considerar a criança diferente do adulto, com "uma existência tão incomensurável” à do adulto, procurava ser inventivo com a intenção de distraí-las. Segundo ele, nada é mais ocioso que a tentativa febril de produzir objetos - material ilustrativo, brinquedos ou livros supostamente apropriados às crianças. Ao criticar os pedagogos de sua época, Benjamin dizia que "em seu preconceito, eles não veem que a terra está cheia de substâncias puras e infalsificáveis, capazes de despertar a atenção infantil". Isto fica claro na seguinte citação:

É que crianças são especialmente inclinadas a buscarem todo local de trabalho onde a atuação sobre as coisas se processa de maneira visível. Sentem-se irresistivelmente atraídas pelos detritos que se originam da construção, do trabalho no jardim ou na marcenaria, da atividade do alfaiate ou onde quer que seja. Nesses produtos residuais elas reconhecem o rosto que o mundo das coisas volta exatamente para elas, e somente para elas (...) com isso as crianças formam o seu próprio mundo de coisas, um pequeno mundo inserido no grande. Um tal produto de resíduos é o conto maravilhoso, talvez - mais poderoso que se encontra na história espiritual da humanidade: resíduos do processo de constituição e decadência da 
saga. A criança consegue lidar com os conteúdos do conto maravilhoso de maneira tão soberana e descontraída como o faz com retalhos de tecidos e material de construção (BENJAMIN, 2009:57-58).

A mesma citação aparece também no livro Magia e técnica, arte e política de Walter Benjamin. Porém, o tradutor optou por utilizar "conto de fadas" ao invés de "conto maravilhoso" (BENJAMIN, 1994:238). Não há em Steiner, ou em Walter Benjamin, a preocupação em explicar ou diferenciar conto de fadas de contos maravilhosos. Para ambos os autores, conto de fadas, mitos, fábulas, lendas, histórias sagradas, contos folclóricos, são narrativas primordiais que são portadoras da história espiritual da humanidade. Elas são heranças de nossos antepassados que estiveram presente na tradição oral dos povos e são portadoras de importantes conhecimentos sobre a vida e a morte, sobre as relações do homem com os outros homens e sobre as relações do homem com a natureza e com o divino. É esta concepção que será considerada nesta tese.

Benjamin considerava a Fábula um produto espiritual de grande profundidade, mas ele não acreditava que a criança ou o jovem fossem atraídos pelo texto ou pela mensagem de moralidade. Muito pelo contrário, ele achava que eles pouco compreendiam da ideia contida no texto. O que atraia e divertia, eram os animais que falavam e agiam racionalmente como os homens (BENJAMIN, 2009:58).

Benjamin, assim como Steiner, criticou a ênfase dada ao ensino racional, ao desenvolvimento intelectual prematuro, e propunha atividades musicais, artísticas, lúdicas para a formação de um ser humano harmônico e integral. Para Benjamin, "a criança não precisa seguir escrevendo até a exaustão"; é necessário que haja espaços para o desenho, para a palavra que falta, para que a criança seja soberana 
sobre o objeto. A criança tem que ter "o poder do comando, tão indispensável para o jogo infantil" ou perderá força diante do objeto da aprendizagem. Segundo ele, quando a criança se sente soberana:

(...) começa a tagarelar o que mal acabou de aprender, a aprontar tolices e disparates com a lição, então esse livro continua sendo o seu melhor amigo. Ele possui suficientes espaços em branco para serem pintados e rabiscados, amplos e férteis territórios nos quais todos os monstros e heróis favoritos do seu dono podem ser confortavelmente instalados (BENJAMIN, 2009:152).

Em ambos os autores, é possível perceber a força das narrativas para a adaptação da criança ao mundo. A força e importância da imaginação e da vivência dos sentimentos essenciais, contra o predomínio puro do intelecto, para a formação do ser humano integral. De acordo com Edgar Morin:

O espírito humano se abre ao mundo. A abertura ao mundo revela-se pela curiosidade, pelo questionamento, pela exploração, pela investigação, pela paixão de conhecer. Manifesta-se pela estética, pela emoção, pela sensibilidade, pelo encantamento diante do nascer e do pôr-do-sol, da lua, da avalanche das ondas, das nuvens, das montanhas, dos abismos, das belezas dos enfeites naturais dos animais, do canto dos pássaros; e essas emoções vivas estimularão a cantar, desenhar, pintar. (...) a originalidade humana manifesta-se na explosão da mitologia e da magia, denunciadas pela ciência como irracionalidade, fazendo, contudo, parte da humanidade assim como a racionalidade (MORIN, 2007:40-41).

Educar pelo sentimento era a chave para Steiner, pois é justamente no sentir que encontram-se os embriões para o conhecer e para os atos da vontade. A 
vontade é determinada por sentimentos que nos impulsionam ou refreiam. Ela está intimamente ligada com as representações (as imagens) que formamos no decorrer de nossas vidas. Daí a importância dada em sua educação para um correto desenvolvimento da vida sentimental da criança, que deve ter esperança, desejo, expectativas em relação à vida.

Para Benjamin:

A criança exige do adulto uma representação clara e compreensível, mas não "infantil". E já que a criança possui senso aguçado mesmo para uma seriedade distante e grave, contanto que esta venha sincera e diretamente do coração, muita coisa se poderia dizer a respeito daqueles textos antigos $e$ fora de moda (BENJAMIN:2002:55) $)^{62}$.

Para Steiner, o bom professor, assim como o poeta, é aquele que conserva por toda a vida certas qualidades da juventude, isto é, mantém em si, como algo bastante especial, a feliz disposição da idade infantil. Aqui, as ideias de Steiner coincidem com as de Walter Benjamin, embora Benjamin não se refira especificamente ao professor ou ao poeta, mas aos adultos em geral, ou a tristeza do adulto (BENJAMIN, 2002:50). Esta característica também é apontada por Mia Couto $^{63}$ no final do livro $O$ Gato e o Escuro, no qual ele tece algumas considerações "sobre o autor". Mia Couto também não se refere especificamente ao professor ou ao poeta, mas à importância de guardar dentro de si o olhar de criança.

A partir destas considerações, passamos a pensar nos jovens recém formados no Ensino Médio em escolas públicas e estaduais, pois é com esse adulto

\footnotetext{
${ }^{62}$ Grifo do autor.

${ }^{63}$ António Emilio Leite Couto, conhecido como Mia Couto, nasceu em 1955, na Beira, Moçambique. Biólogo, jornalista e autor de mais de trinta livros, entre prosa e poesia.
} 
que lidamos em nossa formação e prática educacional há mais de vinte anos. Passamos a questionar o que poderíamos fazer para resgatar ou revivificar esse olhar de criança, olhar de descoberta, curiosidade, criatividade e imaginação, considerados por Steiner, como embrionários para o conhecer e para o agir. Será que isto é possível por meio da literatura? O que acontece quando um jovem adulto tem em suas mãos um livro infantil e o utiliza da maneira proposta por Steiner?

Passamos a questionar quem é esse adulto formado pela pedagogia Waldorf; ele é diferente de um adulto formado por outra pedagogia? É mais sensível? Menos individualista? Tem uma visão mais positiva sobre as questões essenciais da vida? O que pensa sobre a vida, a morte, a velhice? Quais são seus medos? Qual a sua relação com a leitura? Ele mantém o hábito de ler na vida adulta? Resumindo, é possível estabelecer semelhanças e diferenças com relação aos interesses e hábitos de leitura e posicionamento em relação às questões essenciais da vida, como a morte e a velhice, entre adultos formados pela pedagogia Waldorf e adultos formados por outras pedagogias?

Acreditamos ser pertinente qualquer discussão que vise melhorar a formação dos jovens no Brasil, visto que a cada ano que passa esses jovens chegam cada vez menos preparados para a graduação, para a vida, para o mundo. É possível perceber uma deficiência considerável em habilidades básicas de leitura, escrita e raciocínio lógico nos calouros de universidades particulares, fato que pode ser verificado nos resultados apontados pelo PISA - Programa Internacional de Avaliação de Estudantes coordenado no Brasil pelo Instituto Nacional de Estudos e Pesquisas Educacionais Anísio Teixeira (Inep). Realidade testemunhada por nós nos vinte e dois anos de trabalho realizados em uma instituição particular de ensino 
universitário, que é responsável pela formação, em São Paulo, de um número expressivo de futuros cidadãos e profissionais.

Essa mesma questão impulsionou Lucia Santaella a buscar na fenomenologia de Pierce $^{64}$ uma resposta, cujo resultado pode ser conferido no livro Matrizes da linguagem e pensamento: sonora visual verbal: aplicações na hipermídia. Logo no início do livro, Santaella coloca a seguinte questão:

(...) por que os alunos entram na universidade sem a capacidade desenvolvida de ler, compreender e, sobretudo, de escrever textos de modo coerente e claro? (...) sabíamos corrigir erros de gramática e detectar porque eles ocorriam, mas não sabíamos de onde vinham as dificuldades reveladas pelos alunos para estruturar um texto coerente. Precisávamos, portanto, compreender o que é um texto como um todo para conhecer quais são os problemas para além da gramática que o afetam (...) Para Pierce, a fenomenologia tem por função responder a mais antiga questão que a filosofia desde os seus primórdios tem se feito: como se dá a apreensão e compreensão do mundo pelo ser humano? (SANTAELLA, 2005:14)

Santaella partiu das concepções de Pierce, da ideia de que não há pensamento sem signos, e de que essa concepção de representação ou signo "é fundamental ao pensamento, ação, percepção e emoção humanas" (SANTAELLA, 2005:31) e das três categorias fenomenológicas (primeiridade, secundidade e terceiridade) para responder as questões que a afligiam. Partiremos das concepções de Steiner para responder as questões que nos afligem, dos quatro estágios propostos por ele (estágio da percepção, estágio do sentir, estágio do pensar ou representar e estágio do pensar conceitual).

\footnotetext{
${ }^{64}$ Charles Sanders Peirce (1839-1914). Nascido em Cambridge, Massachussets, formado em física e matemática pela Universidade de Harvard e em química pela Lawrence Scientific School.
} 
A imagem do homem que norteia a Pedagogia Waldorf exige que este, como indivíduo espiritual, anímico e físico, lute para realizar a sua imagem arquetípica. Lute para combater as forças mecanicistas que combatem sua vontade e se coloque em condições de julgar e buscar um ideal. A pedagogia Waldorf é uma pedagogia voltada à criança e ao adolescente e tem a finalidade de prepará-los para a vida, formando o homem que busca a sua auto-realização de acordo com a sua natureza intrínseca, sua evolução histórica e a sua posição no cosmo.

É através da existência pelo desejo, isto é, do esforço do homem por existir e do seu desejo de ser, que o homem estabelece relações com outros homens, utilizando-se da linguagem, com seus signos e símbolos para exprimir ou reprimir seus desejos e relacionar-se com os outros homens. Inserido em uma comunidade, com valores religiosos, culturais, morais etc., o homem expressa suas ideias, seus sonhos, opiniões.

\subsection{INDICAÇÕES DE NARRATIVAS PROPOSTAS POR SEGUIDORES DE STEINER}

No seminário ministrado em 1919 por Steiner aos futuros professores da primeira escola Waldorf, foram apresentados alguns poemas e contos a serem trabalhados com as crianças, conforme citado no item 2.6 desta tese, sendo dado aos professores muita liberdade na escolha das obras de acordo com preferências pessoais e necessidades específicas dos alunos e da sala como um todo.

É interessante constatar que apesar de Rudolf Steiner ter falecido em 1925, a 
prática pedagógica fundada por ele continua viva em todas as escolas Waldorf ao

redor do mundo. Alunos formados por essa pedagogia continuam a ouvir histórias

narradas por seus professores e a recitar versos até o décimo segundo ano da vida

escolar. Até 1996, não haviam registros sobre a narração de histórias nas escolas

Waldorf. De acordo com Ronilda Yakemi Ribeiro65:

(...) O curioso é que, embora reconhecida como um dos principais pilares e um dos principais eixos organizadores da prática pedagógica, o discurso sobre a importância da narrativa oral e o modo adequado de ministrar ensinamentos por seu intermédio também permaneceu no plano da oralidade, transmitido de geração em geração de professores, numa cadeia de transmissão oral (...) foi uma surpresa enorme constatarmos que o registro escrito de tão relevante recurso pedagógico Waldorf ainda não fora realizado. Mapeando toda a comunidade Waldorf do Planeta, demo-nos conta de que, realmente, tratava-se de iniciativa nova. Lino de Macedo66 que, juntamente com Rudolf Lanz ${ }^{67}$, compôs a banca de exame de qualificação para o mestrado - brincou dizendo que Sueli e eu éramos as Irmãs Grimm (PASSERINI, 2011:14-15).

${ }^{65}$ Ronilda Ribeiro é Graduada e Mestre em Psicologia pela Universidade de São Paulo, Doutora em Psicologia Escolar e do Desenvolvimento Humano e em Ciências Sociais (Antropologia da África Negra) pela Universidade de São Paulo.

${ }^{66}$ Lino de Macedo é graduado em Pedagogia pela Faculdade de Filosofia Ciências e Letras de São José do Rio Preto, mestre, doutor e livre docente em Psicologia pela Universidade de São Paulo.

${ }^{67}$ Rudolf Lanz (1915-1998) - filho de pais alemães, nasceu em Budapest. Estudou Direito em Genebra, Munique e Londres, tendo se doutorado em Direito aos 21 anos em Genebra. Emigrou para o Brasil em 1938. Foi um dos divulgadores da Antroposofia no Brasil e um dos fundadores, em 1956, da primeira escola Waldorf de São Paulo no bairro de Higienopolis, tendo recebido o nome de Escola Higienópolis. Poucos anos após sua fundação a escola mudou-se para sua atual sede na Rua Job Lane 900, em Santo Amaro. Em 1976, o Presidente da Sociedade Antroposófica Geral, Rudolf Grosse, denominou-a Escola Rudolf Steiner de São Paulo. Posteriormente, o nome foi mudado para Escola Waldorf Rudolf Steiner de São Paulo. Em 1970, Rudolf Lanz e sua esposa Mariane Lanz fundaram nessa escola o Seminário Pedagógico Waldorf, atualmente Centro de Formação de Professores Waldorf, responsável pela formação de professores nessa pedagogia no Brasil e na América Latina. Em 1981, Rudolf Lanz fundou, juntamente com Jacira Cardoso e um grupo de colaboradores, a Editora Antroposófica. Em 1994, a Editora Antroposófica abriu sua livraria na Rua da Fraternidade, em São Paulo. A editora já publicou cerca de 200 títulos, sendo Rudolf Lanz um dos responsáveis por boa parte das traduções das obras de Steiner para o português. Em 1982, por iniciativa de Rudolf Lanz e com a ajuda de colaboradores foi fundada a Sociedade Antroposófica no Brasil, sendo presidida por ele até meados de 1995 (http://www.sab.org.br/portal/antroposofia2/bibliografia em 23/02/2014). 
A citação acima, faz parte do prefácio escrito para o livro O fio de Ariadne: um caminho para a narração de histórias de Sueli Pecci Passerini68, publicado em 1998 e reeditado em 2004 e em 2011. O livro é o resultado da Dissertação de Mestrado, $O$ fio de Ariadne: múltiplas formas narrativas e desenvolvimento infantil segundo a abordagem antroposófica de Rudolf Steiner, defendida em 1996, no Instituto de Psicologia da Universidade de São Paulo, sob a orientação de Ronilda Yakemi Ribeiro.

O livro de Sueli Passerini é composto por cinco partes. Na primeira parte apresenta a concepção antroposófica do ser humano com especial destaque para o desenvolvimento da criança e a imagem deste desenvolvimento. Na segunda parte, define as múltiplas formas narrativas (contos de fada, contos maravilhosos, fábulas, lendas e mitos) apresentando as concepções dos contos de fada e dos mitos na Antropologia e na Psicologia Analítica. Na terceira parte é apresentado o desenvolvimento da consciência na Antroposofia. Na quarta parte, Passerini trata especificamente do contar histórias e do como contá-las. E, na quinta parte, analisa o processo de individuação do ser humano por meio de um dos contos coletados pelos Irmãos Grimm: "Rosa Vermelha e Rosa Branca”.

As indicações de leituras propostas por Sueli Pecci Passerini no livro O fio de Ariadne: um caminho para a narração de histórias, para o período anterior à troca dos dentes, "deverá recair entre aqueles que se ligam a conteúdos verdadeiros, como os veiculados nos contos de fada coletados pelos Irmãos Grimm, por exemplo"

\footnotetext{
68 Sueli Pecci Passerini é Mestre e Doutora em Psicologia pela Universidade de São Paulo. Foi professora durante quinze anos no Colégio Waldorf Michael de São Paulo, tendo participado de sua fundação. Nesta escola, Sueli foi professora do filho mais velho de Ronilda Yakemi Ribeiro. Desde 1994 leciona em cursos da Fundação Armando Álvares Penteado (FAAP). Participou da fundação da Associação Sophia de Educação Antroposófica, em São Paulo sendo responsável por sua coordenação pedagógica. Atualmente coordena cursos de pós-graduação em Pedagogia Waldorf.
} 
(PASSERINI, 2011:22). Ela nos explica que:

Os contos de fada narrados no jardim de infância Waldorf pertencem à coletânea dos Irmãos Grimm. Os contos narrados mais sistematicamente nesse momento de vida da criança, respeitando-se as preferências das professoras, são: "Mingau doce", "O lobo e os sete cabritinhos", "Chapeuzinho Vermelho", Rumpelstiltskin", "A Senhora Holle", "A rainha das abelhas", "Rapunzel”, "O sapo rei”, "Os gnomos", "As moedas caídas do céu", "Os três raminhos verdes", "As três plumas", "O velho Rink e Rank", "Os músicos de Bremen”, "Os seis cisnes", "O burrinho", "O ganso de ouro", "Rosa Vermelha e Rosa Branca", "Cinderela", "Branca de Neve". Na verdade, nem todos os contos citados são obrigatoriamente narrados, sendo essa seleção representativa da escolha do já citado grupo de professoras $^{69}$ (PASSERINI, 2011:108)

Assim como estabelecido por Steiner, quando da fundação da primeira escola Waldorf, Passerini relata que:

Os critérios de escolha serão definidos pela empatia que o professor estabeleça com a história, o estágio de desenvolvimento ou maturidade dos alunos (momento da classe), suas necessidades de âmbito social e/ou a relação com as épocas do ano, a saber: Páscoa, São João, São Micael e Natal (PASSERINI, 2011:118).

Para o oitavo ano de vida da criança é indicada a história "Os dois irmãos", também da coletânea dos Irmãos Grimm, como preparo para a mudança que irá ocorrer na criança a partir do nono ano de vida. Seria a passagem do "mundoobjeto" para o "eu-sujeito", ou do "mundo é bom" para o "mundo é belo". Nesta fase

${ }^{69}$ Ana Cândida Zaeslin, Ana Abreu, Cristina Brigagão Ábalos, Edith Asbeck, Luiza Lameirão e Maria Helena de Oliveira e Souza - professoras que trabalham ou trabalharam com a Pedagogia Waldorf, colegas de Sueli Passerini que contribuíram no conteúdo do livro por meio do relato de suas experiências. 
da vida da criança são indicados também a narração de fábulas de animais representando os instintos humanos e lendas de santos representando os ideais. Como indicação de lenda, Passerini cita a de São Francisco e o lobo de Gubbio (PASSERINI, 2011:122) e como indicação de fábula a da Raposa e da Cegonha (PASSERINI, 2011:123). De acordo com ela:

\begin{abstract}
As lendas de santos são contadas no mesmo ano em que as fábulas, como contraponto a estas. O homem não vive só os grandes ideais, nem tampouco apenas seus desejos, impulsos e cobiças; na realidade ele necessita harmonizar essa dualidade. A ideia educativa que orienta essas narrações de fábulas e lendas é mostrar que em verdade os instintos existem, e que através de modelos ideais os instintos são transformados (PASSERINI, 2011:123)
\end{abstract}

Em seguida, Passerini explica a importância em se introduzir, a partir do nono ano de vida da criança, histórias do Velho Testamento, aos dez anos de idade, mitologia nórdica e, aos onze anos de idade, histórias da Atlântida até Grécia e Roma. Dos doze aos catorze anos de idade, são indicadas biografias, histórias de figuras célebres, como modelos ideais de coragem, justiça, comportamento. Sendo que, de acordo com Passerini, a primeira biografia propriamente dita, narrada nas escolas Waldorf é a de Alexandre, o Grande (PASSERINI, 2011:135). Em suas palavras:

A biografia de Alexandre inicia a História propriamente dita enquanto
matéria curricular, fora do âmbito mitológico. A continuação desse
conteúdo será feita com a vida de personalidades históricas como,
em Roma, as grandes individualidades de Júlio César, Demóstenes,
Marco Antonio e muitos outros. Toda a Idade Média é vivenciada com
as figuras de Joana D’Arc, Carlos Magno, Rolando e Ricardo 
Coração de Leão, entre outras. Na Idade Moderna, com o renascimento da arte, com os descobrimentos, a nova visão de mundo tem em suas personalidades mais proeminentes toda uma galeria de notáveis. Com a biografia de Maria Antonieta, e por meio de todas as intrigas da corte, é possível transmitir um grande conhecimento histórico, além de qualidades ou dificuldades personalizadas em outras figuras da época. O carismático Napoleão promove grandes simpatias e grandes antipatias, partidarismos que ensinam a fazer escolhas na vida (PASSERINI, 2011:135-136).

Mais uma vez é enfatizado o fato de que a escolha ou a ênfase de um aspecto específico da vida de cada personalidade escolhida deve ser feita de acordo com as afinidades e interesses do professor, a necessidade dos alunos e do grupo de alunos como um todo. O que dá aos professores das escolas Waldorf muita liberdade com relação às narrativas a serem apresentadas aos alunos.

Nosso contato com a obra de Sueli Pecci Passerini foi posterior à leitura da obra Pädagogischer Aauftrag und Unterrichtsziele einer Freien Waldorfschule publicada em 1995, em Stuttgart. Esta obra foi editada como publicação interna do Círculo de Professores de Haia, pelo Departamento de Pesquisas Pedagógicas da Federação das Escolas Waldorf. Foi traduzida para o português por Rudolf Lanz e publicada no Brasil em 2002, pela Federação das Escolas Waldorf no Brasil com o título Objetivo pedagógico e metas de ensino de uma escola Waldorf.

Composta por três capítulos distribuídos em mais de 380 páginas, apresenta, no primeiro capítulo, o objetivo pedagógico e metas de ensino de uma escola Waldorf; no segundo capítulo, apresenta o currículo horizontal do ensino fundamental (do $1^{\circ}$ ao $8^{\circ}$ ano de uma escola Waldorf) ao ensino médio (do $9^{\circ}$ ao $12^{\circ}$ ano de uma escola Waldorf) confrontando-os com pontos de vistas antropológicos; e, 
no terceiro capítulo, são apresentados os currículos básicos verticais do $1^{\circ}$ ao $12^{\circ}$ anos: língua materna, línguas estrangeiras (inglês, francês, russo, línguas clássicas - grego/latim), noções de história e geografia local, geografia e economia, história e sociologia, história da arte, filosofia, religião, cálculo e matemática, ciências naturais - biologia e ecologia, física, química, tecnologia, informática, educação física, educação musical, eurritmia, educação artística (pintura, desenho, arte gráfica, modelagem-escultura), artes aplicadas, jardinagem e os projetos, estágios e épocas práticas. Entre as artes aplicadas são destacados: trabalhos manuais (cestaria, costura, fiação, batique, tecelagem, cartonagem e encadernação), artesanato (marcenaria, trabalhos em metal, trabalhos em cobre, forja e fundição), teatro de bonecas. Entre os projetos, estágios e épocas práticas são destacados: estágio de agrimensura, prática de silvicultura, primeiros socorros, estágio social, estágio industrial, semanas de teatro, viagem de arte e trabalhos manuais.

A obra é muito extensa e trata de assuntos diversos. Daremos ênfase às partes que tratam das narrativas e, mais especificamente, do $1^{\circ}$ ao $8^{\circ}$ ano escolar, visto que é este período que iremos propor trabalhar nesta tese. Iniciaremos com a seguinte citação:

O Material Narrativo acompanha "o caminho da criança rumo a terra". Enquanto que nos Contos de Fada (1‥ ano) é vivenciado o todo, a totalidade composta por ser humano, animal, natureza e céu, no segundo ano ocorre uma diferenciação nas Fábulas e Lendas de Santos, para então, nos relatos da Criação do Mundo (Gênesis) e do Antigo Testamento, permitir-se a vivência da responsabilidade do ser humano perante o mundo e perante Deus (no $3^{\circ}$. ano). (No entanto, isto vale principalmente para as civilizações orientadas pelo Cristianismo. Para escolas Waldorf em países budistas, hinduístas, maometanos ou israelitas, convêm procurar outros temas análogos) 
(FEDERAÇÃO DAS ESCOLAS WALDORF, 2002:27) ${ }^{70}$.

Em todas as escolas Waldorf, a primeira aula matinal, chamada de aula principal, prevê um período de uma hora e quarenta e cinco minutos sem intervalo. A aula principal deve ter uma parte rítmica no início e uma parte para narrativa nos últimos quinze minutos.

No $1^{\circ}$. ano da vida escolar da criança, a aula principal inicia com a recitação de poesias e com exercícios musicais curtos (parte rítmica) e termina com o momento do conto (parte narrativa). São indicados versos infantis mais longos e complexos dos que os utilizados no jardim da infância, poesias como as de Clemens Brentano $^{71}$, Achim von Arnim ${ }^{72}$, Goethe, Eduard Mörike ${ }^{73}$, Theodor Fontane ${ }^{74}$, além de canções e cirandas. Os contos, no primeiro ano, devem ser os contos de fada populares. A forma como os contos são narrados é importantíssima. Devem ser narrados com clareza, com entonação correta, pois ajudam no desenvolvimento da fala e na vivência sonora da língua materna (FEDERAÇÃO DAS ESCOLAS WALDORF, 2002:75-76). Com relação à coletânea dos irmãos Grimm é dito o seguinte:

Nas regiões de língua alemã, o estilo dos irmãos Grimm constitui a forma linguística mais genial; nela o mundo das imagens dos contos de fada é mais transparente para sua realidade subjacente. A construção de frases simples em parataxe - que o narrador conserva com firmeza - ajuda a evitar que sentimentos subjetivos venham a se intrometer na narração o que faz com que os contos sejam transferidos do seu ambiente imaginativo para o dia-a-dia onde

\footnotetext{
70 [os grifos são do autor].

${ }^{71}$ Clemens Bremtano (1778-1842), poeta, contista e novelista alemão.

${ }^{72}$ Archim von Armin (1781-1831), poeta e romancista alemão.

${ }^{73}$ Eduard Mörike (1804-1875), poeta e novelista alemão.

74 Theeodor Fontane (1819-1898) escritor alemão.
} 
perdem toda a sua validade. (Recomenda-se a edição completa em três tomos da editora Reclam. O posfácio do editor Heinz Rölleke também merece atenção). A questão do valor dos autênticos contos de fada para o desenvolvimento anímico harmonioso das crianças, mereceria uma atenção especial (FEDERAÇÃO DAS ESCOLAS WALDORF, 2002:76) $)^{75}$.

Como sugestões de Lendas da natureza para o primeiro ano são indicados a coletânea de Lindholm, por exemplo, Wie die Sterne entstanden ("Como nasceram as estrelas"); Die Bedeutung der Phantasie für Emanzipation und Autonomie des Menschen ("A importância da fantasia para a emancipação e autonomia do homem") de E. Funcke e Die sinnige Geschichte ("A história engenhosa") de I. Finkbeiner (FEDERAÇÃO DAS ESCOLAS WALDORF, 2002:144).

No segundo ano, devem ser introduzidos os contos que falam sobre os animais, histórias do reino animal e fábulas. Além das recitações em coro, deve-se iniciar a recitação individual e a encenação de pequenas peças. Uma das obras indicadas nesta fase é A terrível história do galo e da galinha de Clemens Brentano, extraída de Des Knaben Wunderhorn (coleção tradicional de contos, rimas e histórias populares da Alemanha) (FEDERAÇÃO DAS ESCOLAS WALDORF, 2002:80-81). Entre os contos indicados ao segundo ano estão: As pedras de Plouhinec (conto bretão), A dedaleirinha (conto irlandês), Como nasceram as Estrelas (contos noruegueses), A criança e o carvalho, O aleijado e a corça, O lobo e a moeda de ouro, De onde vem a água, O mineiro e o pequeno povo, entre outros (FEDERAÇÃO DAS ESCOLAS WALDORF, 2002:144-145).

$\mathrm{Na}$ parte rítmica do terceiro ano, deve-se introduzir poesias sobre a natureza e, no momento do conto, histórias do Antigo Testamento, "considerando-se também

\footnotetext{
75 [os grifos são do autor].
} 
as grandes figuras de Noé, Abraão, Moisés etc. (FEDERAÇÃO DAS ESCOLAS WALDORF, 2002:84).

A partir do quarto ano, termina a fase da imitação, que é melhor explicado na seguinte citação:

\begin{abstract}
Nos três primeiros anos, todo o ensino é oral - isto é, o trabalho consiste em ouvir, entender, falar, cantar e brincar. $O$ aprender se baseia na imitação. No quarto ano vem a fixação da língua pela escrita e a compreensão desta, muitas vezes tão diferente dos sons ouvidos (...) Nos anos seguintes vem a predominar a própria atividade e iniciativa do aluno. As capacidades linguísticas são ampliadas e consolidadas; o aluno é estimulado a penetrar mais conscientemente na língua e em seus conteúdos (FEDERAÇÃO DAS ESCOLAS WALDORF, 2002:118).
\end{abstract}

De acordo com Steiner, é no quarto ano que a atenção da criança se concentra definitivamente na natureza tal como é percebida pelos sentidos. Neste ano, além de dar continuidade à recitação de poesias sobre a natureza, deve-se introduzir poesias que mostram a prudência e sabedoria dos homens. Para isso, são indicados os poemas de Peter Huchel (1903-1980) e trechos das poesias de Edda, a lenda dos deuses e heróis germânicos, a mitologia nórdica (FEDERAÇÃO DAS ESCOLAS WALDORF, 2002:91). É indicado The Gingerbread Boy de U. TaylorWeaver como primeira leitura para as aulas de inglês (FEDERAÇÃO DAS ESCOLAS WALDORF, 2002:119).

O quinto ano é apropriado para as obras de outras culturas. Para a parte rítmica do quinto ano é sugerido, por exemplo, Herr von Ribbeck ("O Senhor de Ribbeck") de Fontane e Bauerngarten ("Jardim rural") de Weinheber ${ }^{76}$. Com relação

\footnotetext{
${ }^{76}$ Josef Weinheber (1892-1945), poeta austríaco.
} 
aos assuntos para narrações ou leitura, sugere-se narrativas sobre as antigas civilizações orientais - Buda, Gilgamesh, Isis e Osiris, por exemplo - e lendas da Antiguidade Clássica e, também, à civilização dos celtas. Alguns títulos sugeridos são: Fionn der Held ("Fionn, o herói") de James Stephens ${ }^{77}$, Am Rande von Atlantis ("Na beira da Atlântida"), Brendams wunderbare Meerfahrt ("A maravilhosa viagem marítima de Brendam") e Yvain der Löwenritter ("Yvain, o cavalheiro do leão") de Erika Dühnefort (1917-2003), Ferien auf Saltkrokan ("Férias em Saltkrokan") de Astrid Lindgren (1907-2002) ${ }^{78}$ e Die Flucht nach Ägypten. Ihr königlich böhmischer Teil ("A fuga ao Egito. Sua parte real boêmia") de Otfried Preußler (FEDERAÇÃO DAS ESCOLAS WALDORF, 2002:94-97). Para escolas que trabalham com o francês como língua estrangeira, há duas sugestões de leitura: La Claire Fontaine (vol. I e II) de D. Fink e La Tarasque à Tarascon de A. Denjean (FEDERAÇÃO DAS ESCOLAS WALDORF, 2002:131).

$\mathrm{Na}$ parte rítimica referente ao sexto ano, são indicadas leituras de Schiller, Goethe, Fontane, Conrad Ferdinand Meyer (1825-1898), Christian Johann Heinrich Heine, Ingeborg Bachmann (1926-1973), Huchel, Sarah Kirsch ${ }^{79}$, entre outros. Nas narrações, esse é o período indicado para introduzir a história moderna (FEDERAÇÃO DAS ESCOLAS WALDORF, 2002:98). No caso do ensino do francês como língua estrangeira, além da sugestão do La Claire Fontaine (vol. I e II) de D. Fink, é sugerido também A Travers la France par le Légendaire de ses Provinces de A. Denjean (FEDERAÇÃO DAS ESCOLAS WALDORF, 2002:131).

\footnotetext{
77 James Stephens (1882-1950), poeta e novelista irlandês.

${ }^{78}$ É considerada uma das escritoras mais famosas da Suécia. Seus livros foram traduzidos em 86 línguas e foram vendidos 80 milhões de exemplares em todo o mundo. Em sua memória, o governo Sueco criou, em 2002, o prêmio ALMA - Astrid Lindgren Memorial Award com o intuito de promover mundialmente a literatura infanto-juvenil.

79 Nascida na Alemanha, em 1935, é conhecida por suas poesias e pelas traduções de livros infantis para o alemão.
} 
É no sétimo ano que o jovem começa a ter consciência de sua própria personalidade. Esse é o período indicado para a introdução da poesia lírica, inclusive a contemporênea. Nessa fase, é importante que o professor leve em consideração a afinidade dos alunos por certas poesias ou poetas. Entre os autores sugeridos, podem ser citados: Kaschnitz, Domin, Huchel, Busta, Bachmann, Kunze, Kunert e Kirsch.

Para a parte da narrativa, esse é o momento de ampliar o interesse das crianças em relação a tribos e povos no mundo inteiro, criando uma compreensão para o diferente (FEDERAÇÃO DAS ESCOLAS WALDORF, 2002:101). Algumas sugestões para as aulas de língua inglesa são: The Little House in the Big Woods de L. I. Wilders, Kidnapped by Indians de O. Spencer e The Farmer and the Goblin de U. Taylor-Weaver (FEDERAÇÃO DAS ESCOLAS WALDORF, 2002:122). Caso a escola trabalhe com o francês como língua estrangeira, as sugestões são: Tartarin de Tarascon de Daudet, Crin Blanc, Le Voyage em Ballon, Le Ballon rouge de Lamorisse e Jacquelin de Denjean (FEDERAÇÃO DAS ESCOLAS WALDORF, 2002:132).

$\mathrm{Na}$ parte rítmica do oitavo ano, deve-se continuar o trabalho iniciado no sétimo ano, porém, é o momento de introduzir as poesias "pensativas" de Goethe e Schiller. São indicadas, por exemplo, Die Sprüche de Konfuzius ("Os provérbios de Confúcio"), Zenit und Nadir ("Zênite e Nadir"), trechos do Das Ideal und das Leben ("O ideal e a vida") e Das verschleierte Bildnis zu Sais ("O retrato velado de sais") de Schiller. Para a parte narrativa, pode-se trabalhar pequenos trechos das seguintes obras: Geschichte des dreißigjährigen Krieges ("História da guerra dos trinta anos") e Geschichte des Abfalls der vereinigten Niederlande von der spanischen Regierung 
("História da revolta dos Países Baixos Unidos contra o governo Espanhol") de Schiller e Ideen zur Philosophie der Geschichte der Menschheit ("Idéias sobre a Filosofia da História da Humanidade") de Herder. Além do contato com os dramas de Schiller ou Goethe (FEDERAÇÃO DAS ESCOLAS WALDORF, 2002:103-104)

Nas aulas de língua inglesa, referentes ao oitavo ano, as sugestões são: Christmas Carol de C. Dickens ou The Road North de A. Horn (FEDERAÇÃO DAS ESCOLAS WALDORF, 2002:123). Nas aulas de francês: Sans Famille de Malot, Le Petit Chose de Daudet, partes de Les trois mousquetaires, Fabiaux du Moyen-âge de Dumas, Fantine, Gavroche de Hugo e Le Tour du Monde em 80 Jours de Verne (FEDERAÇÃO DAS ESCOLAS WALDORF, 2002:132-133).

Finalizaremos a apresentação da obra Objetivo Pedagógico e Metas de Ensino de uma Escola Waldorf com uma citação, um pouco longa, porém importante, pois reforça a ideia inicial de Steiner com relação à liberdade dada aos professores destas escolas para a escolha das obras a serem trabalhadas com os alunos:

\begin{abstract}
A liberdade de ensino é a condição e o pressuposto humano para a realização fidedigna da missão da Educação para a Liberdade. Uma escola que pretende ser viva e atual tem de estimular seus professores a desenvolverem continuamente seus métodos e currículos; o mesmo princípio deve valer para a estruturação do currículo e para a escolha de temas adequados para o trabalho em sala de aula. Por esse motivo, os princípios didáticos também têm mero caráter de diretrizes (...) Precisa, portanto, demonstrar coragem para escolher de acordo com as necessidades pedagógicas ao mesmo tempo em que ele não deve prejudicar a vontade espontânea de aprender, a alegria de saber, a curiosidade, a postura inquiridora e
\end{abstract}

\footnotetext{
${ }^{80}$ [os grifos são do autor].
} 
a capacidade de admiração dos alunos em função de um compromisso com conteúdos prefixados e do volume das matérias. Contudo, a escolha dos conteúdos deve ser submetida à seguinte prova: quais os universos temáticos que têm dimensões humanas, isto é, dimensões universais (p. ex. as narrativas do Antigo Testamento, a transição da cosmovisão ptolomaica à copernicana, o Letimotiv do Fausto como expressão legítima da luta do ser humano pelo conhecimento etc.); quais temas são ligados a um povo (mitologia nórdica, mitos cosmogônicos dos índios, sagas locais, geografia de vários países, canções dos povos, história nacional etc.); e de que forma se manifestam as questões de uma época (Germinal de Emile Zola, Oliver Twist de Charles Dickens, a cultura Biedermeier, o Movimento de 68, Das Vorbild [O Modelo] de Siegfried Lenz, o pós-modernismo etc.)? Disso resulta um campo imenso e muito vivo para a educação, que pode ser transcendido, ampliado e atualizado, o qual, porém, no que se refere ao aspecto humano em geral, não deveria ser reduzido ou afunilado sob algum argumento simplificador de modernidade que, se revela depois, frequentemente, de pouca visão (FEDERAÇÃO DAS ESCOLAS WALDORF DO BRASIL, 2002:7) ${ }^{81}$

É possível perceber, por meio das indicações de leituras apresentadas, a variedade de autores e temas possíveis. Ao mesmo tempo, percebemos que é necessário ter um compromisso e respeito pelas escolhas feitas.

Apesar das várias indicações de leituras propostas em ambas as obras acima citadas, optamos por usar da liberdade conferida por Steiner, e defendida por seus seguidores, para a escolha das obras que iremos trabalhar nesta tese e que serão indicadas no próximo capítulo. Seremos fieis, apenas, à indicação de um conto da coletânea dos Irmãos Grimm, porém, escolhemos um conto que não foi citado nem por Passerini nem pela Federação das Escolas Waldorf do Brasil.

\footnotetext{
${ }^{81}$ [os grifos são do autor].
} 


\section{4}

\section{METODOLOGIA UTILIZADA}

Este capítulo apresenta o método utilizado na pesquisa de campo bem como uma síntese das obras de literatura selecionadas. Inicia com a apresentação dos critérios utilizados para a seleção dos participantes e com a apresentação e justificativa das questões propostas no primeiro questionário respondido por eles. Em seguida, apresenta as obras escolhidas e os critérios utilizados para essa seleção. Finaliza com a explicação da proposta de experiência estética de recepção de leitura desenvolvida com os participantes e com a apresentação do segundo questionário proposto.

\subsection{SELEÇÃO DO GRUPO E DEFINIÇÃO DO QUESTIONÁRIO}

A seleção do grupo pautou-se em uma das hipóteses apresentadas no capítulo anterior, que aventava a possibilidade de estabelecer semelhanças e diferenças entre adultos formados pela Pedagogia Waldorf e adultos formados por outras pedagogias com relação aos hábitos de leitura literária e o posicionamento em relação às questões essenciais da vida, tais como a velhice, a morte e os medos em geral. Fato que levou ao estabelecimento de dois grupos distintos para a pesquisa.

De forma a manter uma coerência entre os participantes de cada grupo, optou-se pela delimitação da faixa etária dos alunos, condicionando-a ao tempo 
decorrido do término do Ensino Médio que não poderia ser maior do que dois anos. Período bastante significativo na vida do adolescente, visto que representa um rito de passagem para a vida adulta, que traz a alegria das conquistas (estar apto para tirar a carteira de motorista, poder comprar bebida alcóolica etc.) e a angústia da decisão por uma profissão, ou para aqueles em que esta decisão já está clara, a angústia em saber se serão aprovados na universidade que gostariam, o que nem sempre acontece.

A decisão com relação à quantidade de participantes em cada grupo ficou condicionada à segunda etapa da pesquisa que prevê uma limitação no universo da amostra para um melhor acompanhamento da experiência estética e análise dos resultados obtidos. Fato que levou a decisão de trabalhar com trinta alunos em cada grupo, porém este número foi reduzido à metade no decorrer da pesquisa, por falta de adesão dos ex-alunos Waldorf.

Os questionários foram enviados aos alunos por e-mail, redes sociais (Facebook) ou entregues em mãos e estabeleceu-se um prazo para sua devolução. No pré-teste, realizado para acerto e definição do questionário, verificou-se que os alunos levam em média de cinco a dez minutos para respondê-lo, sendo composto por dezoito perguntas, oito fechadas, sete semiabertas e três abertas.

A primeira pergunta: "Você frequentou o jardim de infância?" era uma pergunta fechada em que o entrevistado responderia "sim" ou "não". O objetivo desta pergunta era verificar se o participante frequentou a escola antes da alfabetização. $O$ Jardim de Infância proporciona às crianças um contato maior com as artes em geral (desenho, pintura, modelagem etc.) e com o lúdico (ouvir estórias, cantigas, recitar versinhos, brincar, interagir com outras crianças). No caso dos ex-alunos Waldorf, a 
resposta esperada era "sim", visto que este é um período escolar muito importante para a formação da criança, segundo Rudolf Steiner. No caso dos alunos que frequentaram outras pedagogias, eram esperadas respostas variadas.

A segunda pergunta: "Você cursou o Ensino Fundamental e o Ensino Médio na mesma escola?' era uma questão fechada para quem cursou na mesma escola e semiaberta para quem mudou de escola. Para respostas negativas, havia mais uma questão fechada a ser respondida: "Você considera que a mudança de escola foi: boa, ruim ou indiferente", sendo aberto espaço caso o participante quisesse comentar sua resposta. Pretendia-se, com esta questão, verificar se houve mudanças durante a vida escolar da criança, fato que implica em adaptação a novas situações, necessidade de criar novos laços de amizade, entre outros. A troca de escolas pode trazer insegurança, pode ser bom ou ruim. Os alunos que cursaram o Ensino Fundamental e o Ensino Médio em escolas distintas poderiam manifestar-se livremente com relação à mudança, dando uma ideia melhor do que representou a mudança escolar em suas vidas.

No caso dos ex-alunos Waldorf, a resposta esperada era "sim", visto que essa formação visa a um desenvolvimento contínuo e ininterrupto que prevê a passagem do aluno por todas as fases previstas: contato com o professor de classe até o $8^{\circ}$ ano; do $9^{\circ}$ ao $12^{\circ}$ ano contato com o professor tutor; experiências com o teatro no $8^{\circ}$ e no $12^{\circ}$ anos; vivência nas viagens de Agrimensura, Parsival etc. No caso dos alunos formados por outras pedagogias, eram esperadas respostas variadas.

A terceira pergunta pedia aos participantes que assinalassem as atividades praticadas até o final do Ensino Médio indicando as seguintes opções: "canto", "pintura”, “dança”, “teatro”, “desenho”, "ginástica”, “artesanato”, “tricô”, "flauta”, 
"tapeçaria”, "jardinagem”, “modelagem” e "marcenaria”. Logo abaixo da relação a ser assinalada, era perguntado: "Quer mencionar alguma atividade que não foi citada?". Desta forma, os participantes poderiam complementar a lista proposta, caso tivessem realizado alguma atividade não mencionada no questionário. Esperava-se verificar o contato destes alunos com atividades artísticas diversas. No caso dos exalunos Waldorf, a expectativa era que assinalassem todas as atividades propostas e que incluíssem outras. No caso dos alunos formados por outras pedagogias, acreditava-se que muitas atividades não haviam sido praticadas por eles, entre elas, tapeçaria, tricô e marcenaria.

A quarta pergunta: "Como você avalia sua vida até o final do Ensino Médio?" era uma questão fechada com quatro opções de respostas: "excelente", "boa", "ruim" ou "indiferente". O objetivo era aferir se houve uma relação de afetividade com a vida escolar. Acreditava-se que os ex-alunos Waldorf tenderiam às duas respostas mais positivas: "excelente" ou "bom", enquanto que alguns alunos formados por outras pedagogias poderiam responder de forma negativa ou indiferente.

$\mathrm{Na}$ quinta questão, era perguntado ao participante: "Há alguma atividade realizada na escola da qual você tem saudades?". Se a resposta fosse "sim" o entrevistado teria que responder: "Qual?". A intenção era aferir se algum aluno citava leitura, narrativas, recitação de versos ou algo relacionado à leitura literária oral ou escrita. Nesta pergunta não era possível prever a resposta, porém o interesse na pergunta estava diretamente relacionado às respostas que citassem a literatura.

A sexta pergunta: "Você se considera uma pessoa: otimista, realista ou pessimista?' visava verificar a postura adotada perante a vida. Esperava-se que os ex-alunos Waldorf fossem mais otimistas que os demais alunos. 
A sétima pergunta: "Você pratica esportes ou faz ginástica?" oferecia cinco opções de respostas: "nunca", "uma vez a períodos irregulares", "duas a três vezes por mês", "uma vez por semana" e "mais de uma vez por semana" com o objetivo de aferir se os participantes eram ativos ou sedentários. Esperava-se respostas variadas dos dois grupos.

A oitava pergunta: "Você trabalha?' era uma pergunta fechada com possibilidade de resposta: "sim" ou "não". No caso da resposta ser "sim" era feita uma outra pergunta: "Gosta do trabalho que faz" em que eram dadas quatro opções de respostas: "sim", "não", "mais ou menos" e "gosto muito". A intenção era aferir o percentual de ex-alunos que trabalhavam e o grau de satisfação com o trabalho executado. Eram esperadas respostas variadas.

“Você já escolheu sua profissão?” era a nona pergunta do questionário. Para respostas afirmativas perguntava-se: "qual?'. A intenção desta pergunta era aferir se algum ex-aluno Waldorf optaria por Administração, que é a profissão predominante do grupo não formado pela escola Waldorf que participou da pesquisa, alunos do $1^{\circ}$ e do $2^{\circ}$ semestres dos cursos de Administração, Gestão Financeira e Gestão de Recursos Humanos. Esperava-se que os ex-alunos Waldorf já tivessem escolhido uma profissão e que muitos deles tivessem escolhido atividades artísticas ou nas áreas de humanas.

A décima pergunta: "Você está satisfeito com a sua aparência?" era uma questão fechada com cinco possibilidades de resposta: "nunca", "raramente", "às vezes", "quase sempre" e "sempre". O objetivo desta pergunta era aferir o percentual de alunos satisfeitos ou insatisfeitos com sua aparência. Esperava-se que a maioria dos ex-alunos Waldorf respondessem "sempre" e que as repostas dos demais 
alunos variasse.

"Você se considera uma pessoa interessante?" era a décima primeira pergunta do questionário, que oferecia cinco possibilidades de resposta: "nunca", "raramente", "às vezes", "quase sempre" e "sempre". O objetivo desta questão era aferir o percentual de alunos satisfeitos consigo mesmos. Esperava-se que a maioria dos ex-alunos Waldorf respondesse "sempre" ou "quase sempre" e que as respostas dos demais alunos variasse.

Ainda, no âmbito pessoal, a décima segunda pergunta: "Você sabe lidar com suas emoções?' também era uma questão fechada com cinco opções de resposta: "nunca", "raramente", "às vezes", "quase sempre" e "sempre". O objetivo era aferir o percentual de alunos que se consideravam emocionalmente equilibrados. Esperavase que a maioria dos ex-alunos Waldorf respondesse "sempre" ou "quase sempre" e que as respostas dos demais alunos variasse.

A décima terceira questão: "Você tem o hábito de ler?" era uma pergunta fechada com cinco opções de resposta: "nunca", "raramente", "às vezes", "quase sempre" e "sempre". Era uma questão chave para esta tese que visava aferir se os ex-alunos Waldorf mantinham o hábito de ler e se os demais alunos tinham ou não esse hábito. Esperava-se que os ex-alunos Waldorf respondessem "quase sempre" ou "sempre" e que os demais alunos respondessem "às vezes".

Na décima quarta questão era solicitado aos alunos que marcassem com um "X" os autores já lidos por eles e apresentava a seguinte relação de autores: "Shakespeare”, "Balzac”, “Dostoievski”, "Flaubert", "Oscar Wilde”, "Goethe”, "Miguel Cervantes”, “Camões”, "Clarice Lispector", “Dickens”, "Machado de Assis”, “Kafka”, "Monteiro Lobato", "Proust" e "Fernando Pessoa". Logo abaixo da relação a ser 
assinalada era perguntado: "Quer acrescentar algum autor que não conste da relação e tenha sido lido por você?', desta forma, os participantes poderiam complementar a lista proposta, caso tivessem lido outros escritores. O objetivo desta pergunta era aferir os hábitos de leitura literária dos grupos analisados e, principalmente, se lembravam dos nomes dos autores lidos. Esperava-se que os exalunos Waldorf assinalassem a maioria dos autores citados e que os demais alunos marcassem apenas dois ou três autores nacionais.

$\mathrm{Na}$ décima quinta questão era solicitado aos participantes que marcassem com um " $X$ " quais eram os seus medos em uma relação com nove possibilidades: "medo de altura", "medo do escuro", "medo de voar de avião", "medo de lugares fechados", "medo de animais peçonhentos", "medo de envelhecer", "medo de morrer", "medo de sofrer algum acidente" e "medo de dirigir". Foi aberto espaço para que os participantes incluíssem algum outro medo que não fizesse parte das propostas, por meio da seguinte pergunta: "Há algum outro medo que você gostaria de mencionar? Qual?'. Embora fossem esperadas respostas variadas, pretendia-se verificar se a quantidade de medos apontados pelos ex-alunos Waldorf era menor do que a quantidade apontada pelos demais alunos.

As três últimas perguntas do questionário: "Defina a velhice em uma única frase", "Defina a morte em uma única frase" e "Defina a vida em apenas uma frase" eram questões abertas em que esperava-se respostas variadas. Porém, pretendiase verificar, por meio de análise de conteúdo, se era possível analisar semelhanças e diferenças entre os grupos analisados. 


\subsection{APRESENTAÇÃO DAS OBRAS ESCOLHIDAS}

A ideia era propor ao leitor adulto, ainda jovem, recém-saído do Ensino Médio, leituras que o fizessem reviver imagens e representações de sua própria infância. Ao mesmo tempo, propor narrativas que reconectassem esse jovem aos quatro corpos constitutivos propostos por Steiner: seu Eu (por meio de narrativas primordiais portadoras da história espiritual da humanidade), seu corpo astral (por meio de narrativas sobre animais), seu corpo etérico (por meio de narrativas sobre a natureza) e seu corpo físico (por meio de narrativas sobre o próprio homem) (STEINER, 1999:20-21).

Influenciados por uma ideia presente no livro $A$ psicanálise dos contos de fadas, de Bruno Bettelheim (1903-1990) ${ }^{82}$ optamos por estórias que tratassem de temas existenciais, questões do eu, da morte ou do envelhecimento. Segundo Bettelheim:

As estórias modernas escritas para crianças pequenas evitam estes problemas existenciais, embora eles sejam questões cruciais para todos nós. A criança necessita muito particularmente que lhe sejam dadas sugestões em forma simbólica sobre a forma como ela pode lidar com estas questões e crescer a salvo para a maturidade. As estórias "fora de perigo" não mencionam nem a morte nem o envelhecimento, os limites de nossa existência, nem o desejo pela vida eterna. O conto de fadas, em contraste, confronta a criança honestamente com os predicamentos humanos básicos (BETTELHEIM, 1980:14-15) ${ }^{83}$.

\footnotetext{
${ }^{82}$ Psicólogo infantil, especializado principalmente com crianças autistas, nasceu na Áustria em 1903. Graduouse pela Universidade de Viena e mudou-se para os Estados Unidos em 1939. Foi professor de Educação, Psicologia e Psiquiatri na Universidade de Chicago e autor de vários livros.

${ }^{83}$ [os grifos são do autor].
} 
Sabe-se que nem toda estória moderna evita estes problemas e esta foi a força motriz para a seleção das obras propostas nesta tese. Além disso, pretendia-se criar uma sequência de leitura literária de um texto mais simples e singelo da literatura infantil até a leitura de um texto rico em imagens verbais, visuais e sonoras. A escolha das obras foi influenciada e pautada em uma citação de Paul Zumthor:

A noção de "literatura" é historicamente demarcada, de pertinência limitada no espaço e no tempo: ela se refere à civilização europeia, entre os séculos XVII ou XVIII e hoje. Eu a distingo claramente da ideia de poesia, que é para mim a de uma arte da linguagem humana, independente de seus modos de concretização e fundamentada nas estruturas antropológicas mais profundas (ZUMTHOR, 2000:15).

Atendo-se em particular à generalização feita por Zumthor em relação à poesia, definida por ele como "arte da linguagem humana". Ao despi-la de seus modos de concretização e fundamentá-la "nas estruturas antropológicas mais profundas", Zumthor traz o homem que a recebe, o leitor de carne e osso com as suas percepções sensoriais. E é esse corpo que o leitor sente reagir ao contato com um texto poético. De acordo com Zumthor:

(...) é ele que eu sinto reagir, ao contato saboroso dos textos que amo; ele que vibra em mim, uma presença que chega à opressão. $O$ corpo é o peso sentido na experiência que faço dos textos. Meu corpo é a materialização daquilo que me é próprio, realidade vivida e que determina minha relação com o mundo. Dotado de uma significação incomparável, ele existe à margem de meu ser: é ele 
que eu vivo, possuo e sou, para o melhor e para o pior. Conjunto de tecidos e de órgãos, suporte da vida psíquica, sofrendo também as pressões do social, do institucional, do jurídico, os quais, sem dúvida, pervertem nele seu impulso primeiro... Eu me esforço menos para apreendê-lo do que para escutá-lo, no nível do texto, da percepção cotidiana, ao som dos seus apetites, de suas penas e alegrias: contração e descontração dos músculos; tensões e relaxamentos internos, sensações de vazio, de pleno, de turgescência, mas também um ardor ou sua queda, o sentimento de uma ameaça ou, ao contrário, de segurança íntima, abertura ou dobra afetiva, opacidade ou transparência, alegria ou pena provindas de uma difusa representação de si próprio (ZUMTHOR, 2000:28-29).

Ao definir o leitor com seu corpo, no sentido acima exposto, Zumthor passa a questionar o leitor como operador do ato de leitura - o leitor lendo. Ao mesmo tempo, deixa de considerar a leitura como sendo neutra, como sendo unicamente decodificação de uma informação, passando a levar em consideração os elementos não informativos que são aqueles "que têm a propriedade de propiciar um prazer, o qual emana de um laço pessoal estabelecido entre o leitor que lê o texto como tal" (ZUMTHOR, 2000:29).

Zumthor não nega a existência de outros critérios de poeticidade, porém, optou pela perspectiva do prazer que um texto proporciona a determinado indivíduo que passa a considerar aquele texto como poético ou literário. Segundo ele:

(...) é evidente que não nego a existência de outros critérios de poeticidade, que têm a ver com a produção do discurso, desse discurso como tal, o texto ou o grupo social no qual ele funciona. Nesses planos intervêm fatores que designam os termos da tradição, código ou (para tomar uma palavra já muito antiga mas ainda utilizável com prudência) ideologia. Ora, esses fatos permanecem, 
em princípio, exteriores ao que visa a perspectiva que eu escolhi. Dessa perspectiva, parece-me indubitável - e eu tomo um exemplo extremo - que um romance da série Arlequim, para um adolescente apaixonado, possua uma certa poeticidade verdadeira, embora para numerosos indivíduos de nossa sociedade essa poeticidade seja impostura, ou pura e simplesmente inexistente (ZUMTHOR, 2000:30)

A partir das considerações de Paul Zumthor, nos sentimos aptos para determinar os textos literários que fariam parte de nosso estudo.

Iniciamos nossa escolha buscando trazer à consciência do adulto, lembranças ou representações do primeiro estágio de sua vida. Momento em que, de acordo com as concepções de Steiner, é o estágio da percepção, que pode ser melhor compreendido na seguinte citação de Sueli Pecci Passerini:

A criança inicia seu processo de consciência a partir da percepção do mundo, da criação de imagens ricas em conteúdos simbólicos, para alcançar a capacidade intelectual no período da adolescência. Nos primeiros anos de vida, toda ela é um órgão sensório e, como tal, o que percebe não se metamorfoseia em pensamentos lógicos, e sim em imagens conceituais. Mesmo nós, adultos, ao sentir o cheiro de uma comida de nossa preferência podemos imaginá-la, ou seja, podemos ver o alimento; ao ouvir uma música alegre, podemos visualizar algo que nos deixa felizes, como uma festa ou uma dança. Isso é o que faz nesse momento da vida: ela cria imagens em função do que percebe de si mesma e do mundo que a circunda. Antes da troca dos dentes, a criança não percebe o mundo como algo exterior: o mundo faz parte dela própria (PASSERINI, 2011:21).

Foi exatamente a frase "visualizar algo que nos deixa feliz" que nos levou a uma lembrança de infância relacionada a um livro infantil de capa vermelha com 
ilustrações em relevo. Cabe aqui o relato de cunho pessoal: o livro ficava na casa de meus tios e, sempre que chegava lá, corria para ele. Sentava no chão e ficava horas folheando. Não me lembro de nenhuma estória específica, apenas de algumas ilustrações. O livro era o primeiro volume de uma coletânea com quinze volumes. Quando adolescente, herdei a coleção de meus tios, porém faltava o primeiro volume que, de tanto ser manuseado, foi destruído. Ao começar a escrever esta tese, passei a buscá-lo em sebos e, finalmente, o encontrei na internet e o recebi em casa.

A sensação de alegria foi indescritível, apesar de ser muito bem explicada nas palavras de Walter Benjamin:

(...) o livro infantil - só é possível a quem se tenha mantido fiel à alegria que ele desperta na criança (...) Um livro, uma página de livro apenas, ou até mesmo uma mera gravura em um exemplar antigo e fora de moda, herdado talvez da mãe ou da avó (...) Não importa se a capa está solta, se faltam páginas e se vez ou outra mãos desastradas mancharam as xilogravuras (...) (BENJAMIN:2009:54).

A coletânea em questão foi publicada originalmente nos Estados Unidos, em 1923, com o título The Child's Treasury. Teve pelo menos oito reedições e, em 1949, o título foi alterado para Childcraft. Era considerada uma verdadeira enciclopédia para as crianças e seus pais, como nos explica a coordenadora geral, Iva Waisberg Bonow $^{84}$ que juntamente com um grupo de professores do Instituto de Educação do Distrito Federal realizaram as traduções e adaptações da obra. De acordo com Bonow:

\footnotetext{
${ }^{84}$ Catedrática de Psicologia Educacional.
} 
Esta coleção, que bem pode ser considerada uma verdadeira enciclopédia para as crianças e os seus pais, é obra preciosa de que se orgulham os norte-americanos. Entretanto, não poderia ser traduzida para a nossa língua senão no que tem de universal. As crianças, seres em desenvolvimento, possuem certas características em comum, por mais diversas que sejam as suas origens biológicas ou sociais, o que tornou possível conservar o plano geral desta obra, adaptando-a porém às peculiaridades e às experiências familiares ao nosso meio infantil. Tudo, pois, que se referia à tradição, língua, história e costumes, foi adaptado, isto é, substituído pelo que é nosso. Para tomar um exemplo: Os volumes de 1 a 5 obrigaram os tradutores a um admirável esforço de adaptação e criação poética, sempre visando os interesses e as capacidades da criança brasileira (O MUNDO DA CRIANÇA, 1954:5-6).

O primeiro volume apresenta poemas da primeira infância e é dividido em três partes: Histórias da vovozinha, O mundo que nos cerca e No mundo da fantasia. Escolhemos dois versos de autoria de Helena Pinto Vieira ${ }^{85}$, pertencentes à primeira e à segunda parte, respectivamente: "Pobre Vovô!" e "Vocês acreditam?".

Nossa ideia era oferecer aos leitores adultos dois poemas relacionados à infância, sendo um mais curto e o outro mais longo, para reviver os primeiros anos de vida e a fase mais próxima ao ingresso no primeiro ano escolar, conforme proposto por Rudolf Steiner.

\subsubsection{Pobre Vovô!}

O primeiro poema, "Pobre Vovô!", é curto e cadenciado. Mais do que o verbal, o que se destaca é a sonoridade construída pela pulsação do ritmo das rimas ao

\footnotetext{
${ }^{85}$ Coordenadora do Jardim de infância e professora primária.
} 
final das frases intercaladas, uma sim outra não, e pelas aliterações ("ado", "ou", “im”) em coitado/acabrunhado, sentou/provou, rim/enfim, vovozinho/docinho.

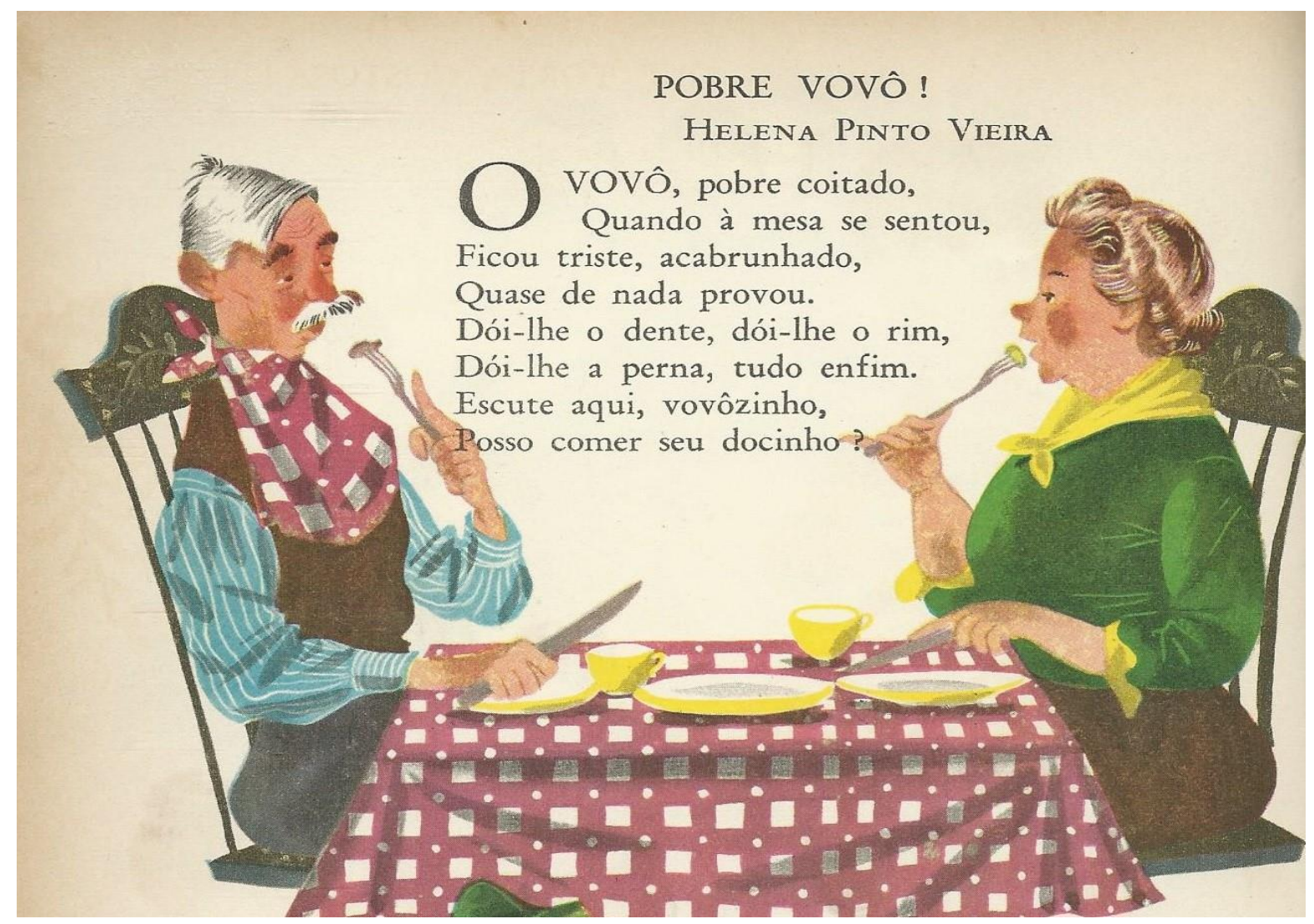

Figura 4.1. Ilustração para o poema Pobre Vovó de Helena Pinto Vieira presente no primeiro volume da coleção 0 Mundo da Criança, na página 28 , sem indicação do ilustrador ${ }^{86}$.

A autora descreve em apenas quatro linhas, a tristeza, o isolamento e as dores que a velhice pode trazer. Ao mesmo tempo, na cadência do dói-lhe isto e dóiIhe aquilo, que remetem aos dodóis da nossa infância, contrapõe com bom humor velhice/infância na alegria de poder comer o docinho. E não é a autora quem narra,

${ }^{86} \mathrm{Na}$ página 8 do primeiro volume da obra, é explicado que foram reproduzidos desenhos de Paulo Werneck, Pedro Penna Filho, Luiz Jardim, F. Acquarone, Renato Silva, Percy Deane, Percy Lau, Dalmo, Monsa, Calixto Cordeiro, Dorca e Nelson Boeira Faedrichs. Porém, em todas as ilustrações do primeiro volume, não há indicações do ilustrador responsável por elas. 
ela empresta sua voz para a criança, que não aparece na ilustração, mas tem sua presença garantida pela voz que fala do e para o avô.

A ilustração é redundante com relação ao que diz o texto verbal. $O$ verbal, portanto, faz-se mais elaborado do que a cena do cotidiano de duas pessoas idosas apresentadas de forma pueril.

É utilizada como simples apêndice ilustrativo e incompleto da mensagem linguística, que pode ser melhor explicado por Maria José Palo e Maria Rosa D. Oliveira:

O livro infantil, desde seus primórdios, tem procurado responder à questão, promovendo formas de diálogos entre a imagem - a ilustração - e o texto verbal. Diálogos nem sempre dialógicos, isto é, dando lugar ao cruzamento de vozes diversas em sintonia no espaço textual. O mais comum é o aparente diálogo que, no fundo, esconde um tom único, privilegiando a informação construída pelo texto verbal em detrimento daquela oriunda do visual. A imagem transforma-se num simples apêndice ilustrativo da mensagem linguística (PALO, 2006:15) ${ }^{87}$.

A criança sai do lugar passivo de receptor e assume a narração. Ela estabelece um diálogo com o leitor ao descrever o vovô com suas dores e consternações, ao mesmo tempo em que se dirige ao avô pedindo permissão para comer seu docinho.

É a forma como o poema diz a velhice, estabelecendo um diálogo entre a voz da criança que narra e a voz do leitor que escuta sua voz, presentificada no momento da sua leitura, fazendo-o ouvir a criança que existe dentro de si, que nos

\footnotetext{
${ }^{87}$ [os grifos são do autor].
} 
fez considerar o poema como literário e possível de ser utilizado em nossa pesquisa.

\subsubsection{Vocês acreditam?}

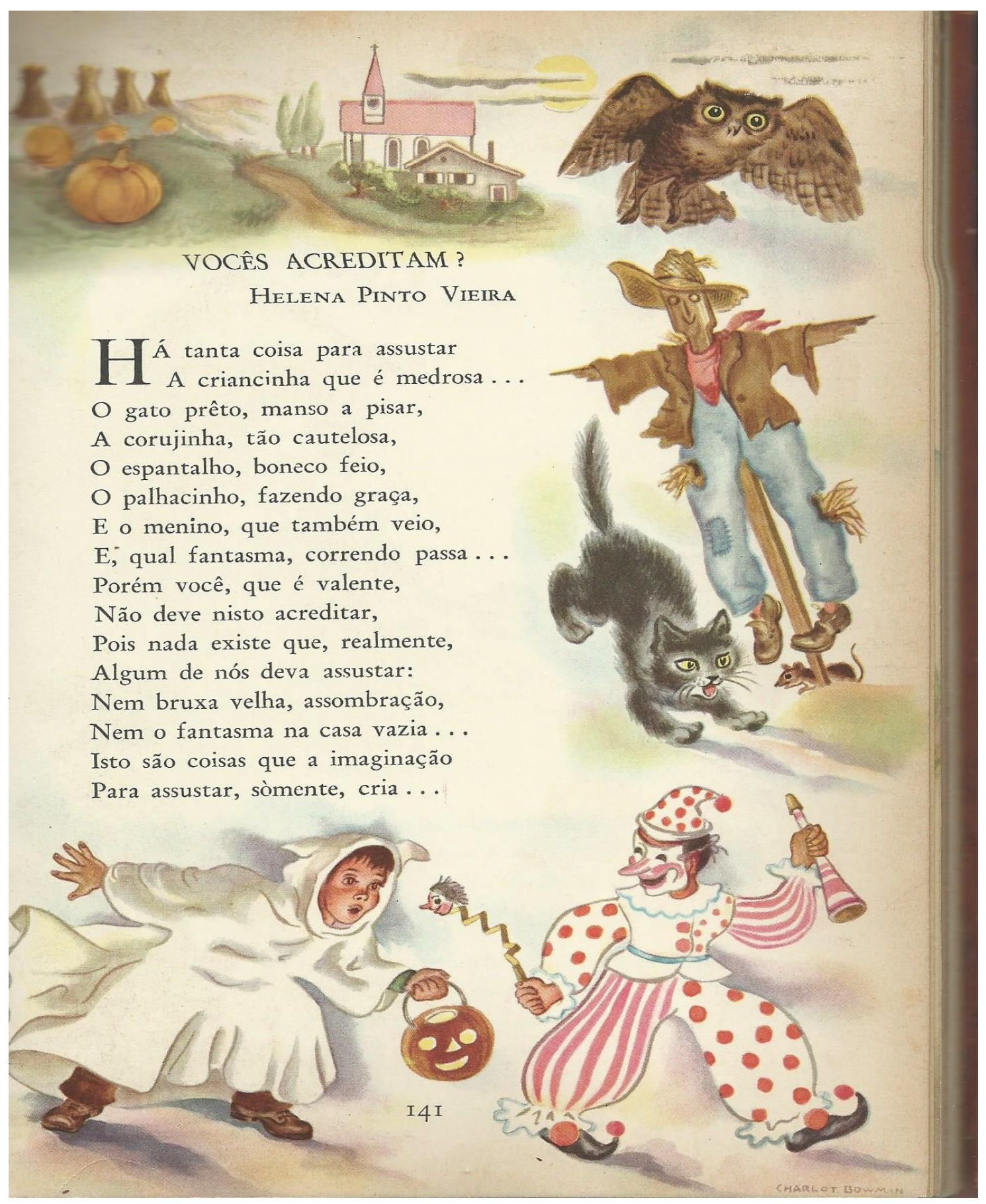

Figura 4.2. Ilustração para o poema Vocês Acreditam? de Helena Pinto Vieira presente no primeiro volume da coleção O Mundo da Criança, na página 141, sem indicação do ilustrador. 
O poema "Vocês acreditam?" é tecido pela pulsação do ritmo das rimas e das aliterações: assustar/pisar, medrosa/cautelosa, feio/veio, graça/passa, valente/realmente, acreditar/assustar, assombração/imaginação, vazia/cria. Podemos ouvir a voz de um adulto que fala para a criança sobre as coisas que a imaginação pode criar para assustar a criancinha que é medrosa.

A ilustração do poema é composta por várias cenas que aparecem como uma moldura incompleta que vai do início do texto escrito, com a paisagem que lhe dá o tom de verismo, abraça-o em toda a sua extensão direita, e termina ao pé da última frase. A coruja que aparece no canto superior direito olha para o leitor. Logo abaixo, o espantalho e o gato que está prestes a dar o bote em um ratinho acuado. $O$ menino com cara assustada vestido de fantasma e carregando uma abóbora de Halloween, segue o palhaço que está andando para frente como se fosse sair da página do livro para o mundo, mas seu rosto está voltado para trás fitando o menino com cara amigável e convidando-o a segui-lo. A ilustração do palhaço nos fez lembrar de um personagem de um filme de terror!

Embora a ilustração contenha quase todos os personagens apresentados pelo texto, aponta caminhos parra novas estórias, novas representações possíveis, novas ideias e novos sonhos, colocando a imaginação em movimento.

O poema é rico em formas sonoras, verbais e visuais que se mesclam e abrem possibilidades para o representar, imaginar e sonhar. $O$ texto do poema contrapõe medo e valentia trazendo à memória personagens presentes no imaginário infantil: bruxa, palhaço, fantasma, espantalho etc. O medo está presente na vida da criança, assim como faz parte da vida dos adultos. O que nos causa medo, não necessariamente é o mesmo que causa medo ao Outro. O mesmo 
palhaço pode ser motivo de alegria para uns e motivo de pânico para outros. As bruxas podem encantar ou amedrontar. Por isso, o texto dá possibilidade ao leitor de se confrontar com os seus próprios medos. Acreditamos que este texto irá fazer com que o receptor adulto reflita sobre os seus próprios medos e, por meio do tom infantil do poema, possa (re)significá-los.

\subsubsection{Vi uma estrela lá fora}

O terceiro livro escolhido, Vi uma estrela lá fora, de Regina Chamlian ${ }^{88} \mathrm{com}$ ilustrações de Helena Alexandrino ${ }^{89}$ foi publicado em 2003. A personagem principal é um menino e é ele quem nos conta a estória. Estória que é puro sentir, no ritmo frenético da pulsação da criança que mergulha em si mesma, introspectiva, fechada em sua tristeza e solidão, para em seguida submergir feliz para o mundo.

Nos momentos de introspecção, a criança quer se esconder do mundo, seja num buraco escuro, ou num quarto fundo, ou dentro de uma caixa ou enrolada em si mesma, olhando para o próprio umbigo. Perdida em seus pensamentos e tristeza pelas dores que o mundo lhe causa, a criança não quer nem ver a cara do mundo. $E$ ela afirma que não adianta assoprar e nem passar pomada, pois a dor custa muito a passar. E são tantas as coisas que lhe causam dor, dores físicas, concretas, como

${ }^{88}$ Regina Chamlian é formada em Cinema pela Escola de Comunicações e Artes da Universidade de São Paulo. Regina escreve também para jovens, é dramaturga e cineasta. Já ganhou vários prêmios, entre eles, melhor texto infantil pela Biblioteca Monteiro Lobato pela obra Trio Tantã, selo Acervo Básico da Fundação Nacional do Livro Infantil e Juvenil pela obra Quando chove e faz sol, selo Acervo Básico da FNLIJ pela obra O livro dos desgastos, selo White Ravens da Biblioteca de Munique e Escritor Revelação da Biblioteca Monteiro Lobato pela coleção Contos de Espantar Meninos.

89 Helena Alexandrino é formada em Artes pela Escola de Comunicações e Artes da Universidade de São Paulo. Pelo seu trabalho como ilustradora foi indicada duas vezes ao prêmio Hans Christian Andersen, o mais importante do mundo para a literatura infantil. Foi indicada ao prêmio Jabuti pelas ilustrações da obra Quando chove e faz sol e recebeu o Prêmio Jabuti pelas ilustrações da coleção Contos para Espantar Meninos. As ilustrações desta coleção foram selecionadas para a Mostra de Ilustrações de Bolonha. Recebeu Menção Honrosa no IV Prêmio de Ilustração da Catalunha. 
ser espetada pelo espinho da sua rosa predileta, que simboliza o sentimento de ser traído por alguém que amamos; ou a dor do cansaço da subida de uma escadaria com tanto degrau e tão comprida, que simboliza o próprio viver, crescer e tornar-se adulto. Há ainda as dores emocionais, que são sentidas na alma, a dor da solidão, a sensação de que o mundo inteiro a esqueceu, a dor que é sentida quando alguém briga com ela ou a coloca de castigo.

O medo de viver e encarar seus sentimentos são dissipados pelo encontro, seja com um animal, ou com um outro alguém, que a faz sair alegre para o mundo. Entre os animais que a fazem emergir de sua tristeza e solidão temos: o gatinho que cruza o seu caminho, uma ave que grita na janela e os olhos vermelhos de um coelho que salta ao cair de uma estrela no mar. E é o carinho de outra pessoa que a faz chorar "bem de mansinho" e descobrir que "carinho é melhor que pomada". Toda sua tristeza e solidão são dissipadas ao ver um amigo que passa correndo pela rua e faz com que o brilho da lua brilhe em seu caminho! Ela então, afirma não mais se sentir sozinha e conclui que viver não é tão perigoso: "Rio alto, rio à toa, dou um abraço amoroso. Viver é uma coisa boa”.

O que nos atraiu, a princípio, foi a ilustração da capa que mais parece um convite para alçar voo rumo à aventura.

A estrela amarela parece puxar o menino rumo ao céu, para além da capa do livro, para uma aventura. Pela forma como as pontas da estrela foram desenhadas parece que uma das pontas representa a cabeça, duas pontas representam os braços e, as outras duas, as pernas da estrela que ganha características humanas. O coelho saltitante no topo superior direito da capa, também está prestes a sair do livro e pode nos remeter ao coelho de Alice no País das Maravilhas. 


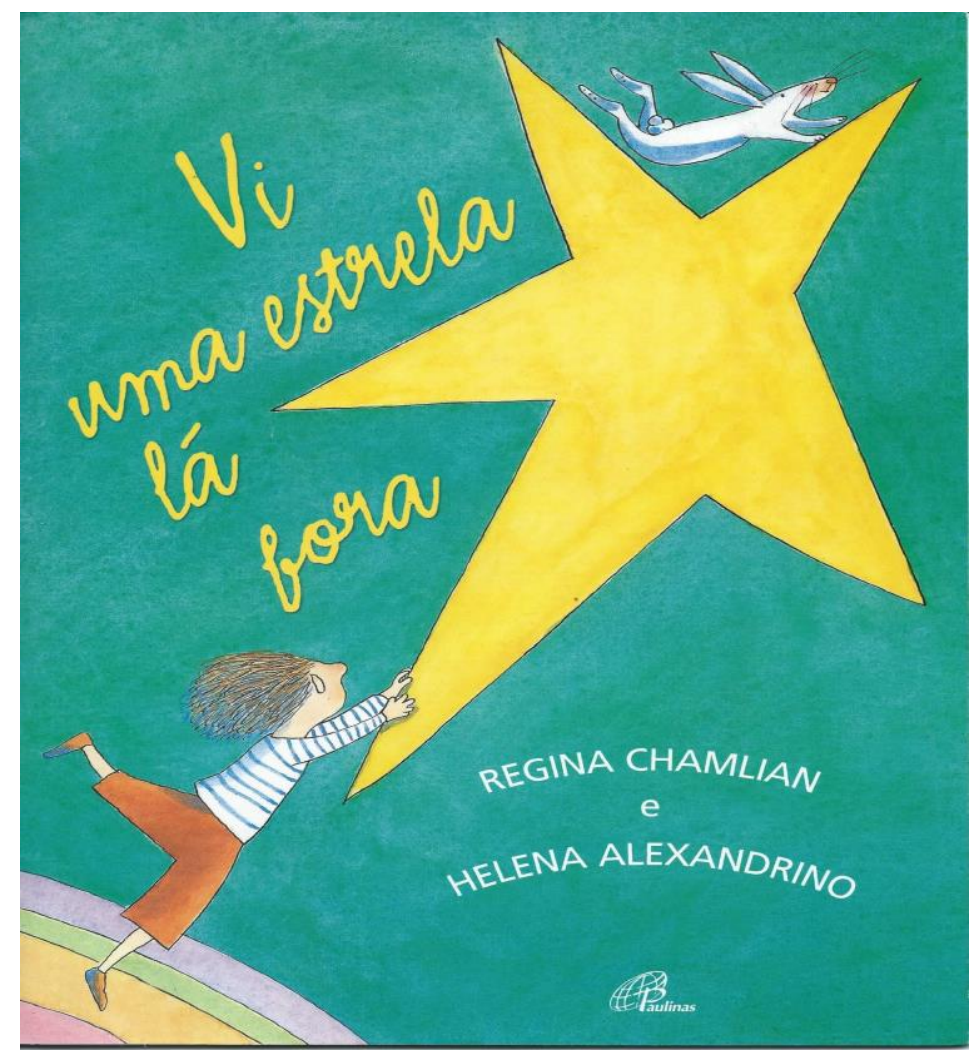

Figura 4.3. Ilustração de Helena Alexandrino para a capa do livro Vi uma Estrela lá fora, de Regina Chamlian.

Ao mesmo tempo em que o livro nos convida à leitura, também nos propõem uma viagem, apontando para o que está lá fora. Dentro e fora, interior e exterior, imersão e emersão, acompanham a trajetória do menino que tem medo de viver. Verbal, visual e sonoro se mesclam, se complementam, se misturam do início ao final do livro que iremos apresentar na íntegra, devido a riqueza da composição do texto verbal com o texto visual.

A estória começa com uma frase que ocupa as duas primeiras páginas e está escrita como um caracol, sendo necessário ler de ponta cabeça ou girar o livro 360ํㅡㄴ graus para poder ler a frase inteira: 


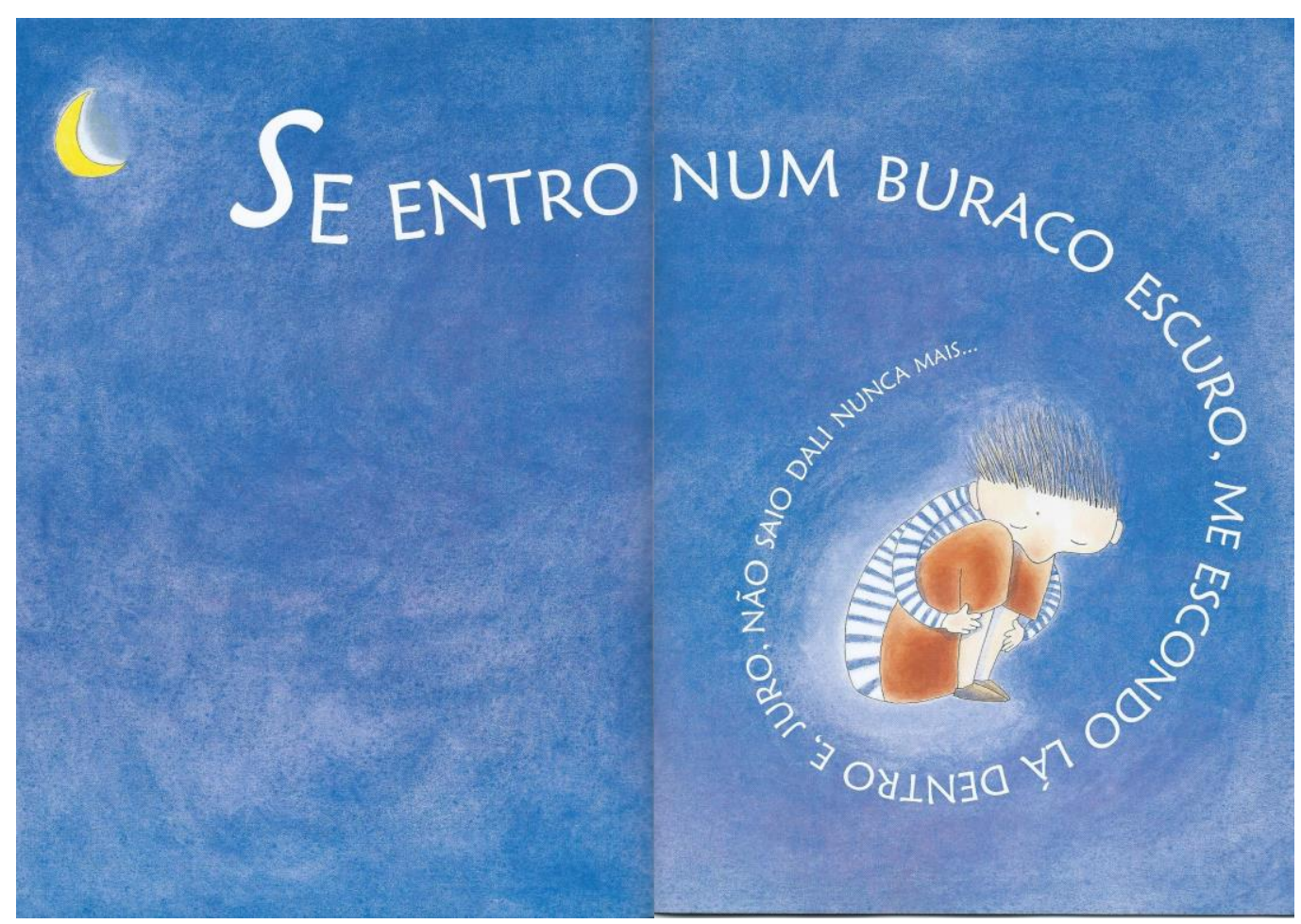

Figura 4.4. Ilustração de Helena Alexandrino para as duas primeiras páginas do livro Vi uma Estrela lá fora, de Regina Chamlian.

O menino está de olhos fechados, em posição fetal, encolhido em sua tristeza. O texto enclausura-o como o ventre materno, protege-o dos perigos do mundo, de volta ao aconchego da barriga da mãe.

Ao virar a página do livro, mais uma vez temos um texto e uma ilustração que ocupam duas páginas. O texto corre, acompanha literalmente os passos da ilustração do menino que corre atrás do gato. O livro é pequeno para a aventura proposta; nem o menino, nem o gato, cabem nas páginas do livro - parte da sua cabeça e um dos seus pés, assim como as patas do gato, estão para fora... Seus limites são ultrapassados pelos personagens que nos ajudam a ouvir a estória contata pelo menino. Do seu rosto é possível ver um dos olhos, o nariz e a boca, e 
ele está feliz. O gato exibido também está feliz!

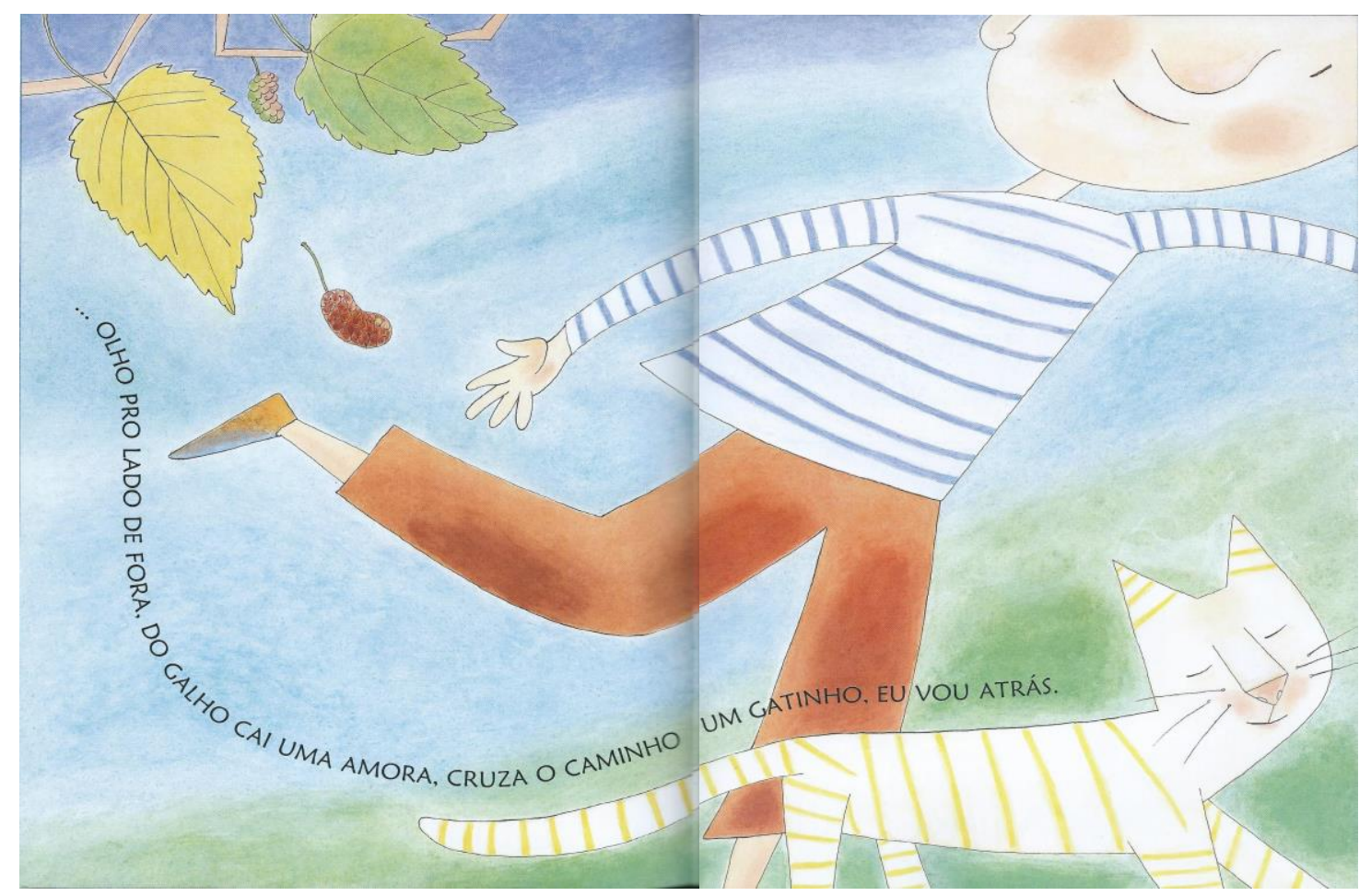

Figura 4.5. Ilustração de Helena Alexandrino para o livro Vi uma Estrela lá fora, de Regina Chamlian.

Toda a tristeza do menino que se encolheu em torno de si mesmo, voltando à proteção do ventre materno, logo no início da estória, é dissipada ao ver o gato que passa e faz com que o menino saia de seu interior atraído pelo gatinho rumo à vida, à aventura.

A terceira ilustração também ocupa uma página dupla e nos mostra uma escadaria a céu aberto. O menino está subindo correndo, já quase alcançando o final da escada que está fora da página e, por isso, só podemos ver parte de sua cabeça; a outra parte já saiu do livro: 


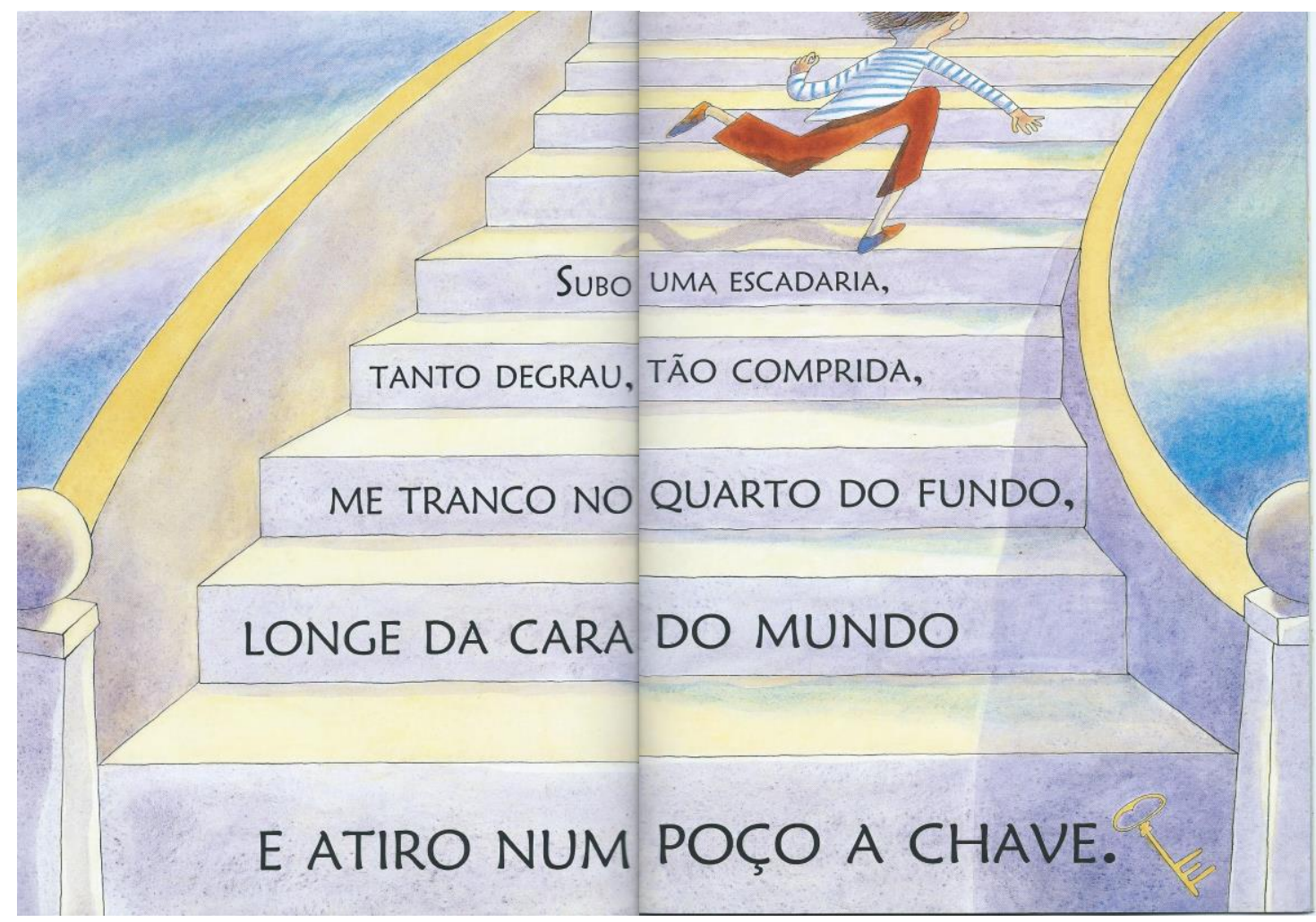

Figura 4.6. Ilustração de Helena Alexandrino para o livro Vi uma Estrela lá fora, de Regina Chamlian.

É mais um momento de introspecção que mostra um cansaço ("tanto degrau, tão comprida") e uma vontade de fugir do mundo ("longe da cara do mundo"). O menino se tranca no quarto e joga a chave fora, num poço; ele não quer ser encontrado. Parece aqueles dias em que queremos morrer, como é difícil encarar a vida, crescer, amadurecer, ser adulto. Ao mesmo tempo em que o menino sobe, o texto verbal desce a escada, e as letras pequenininhas vão ficando maiores, aumentam (crescem!). A dificuldade de crescer, amadurecer, é posta em jogo pela representação simbólica. Será que é tão difícil assim? Ou a vida pode ser uma grande aventura?

Ao virar a página, mais uma ilustração que ultrapassa os limites do livro: 


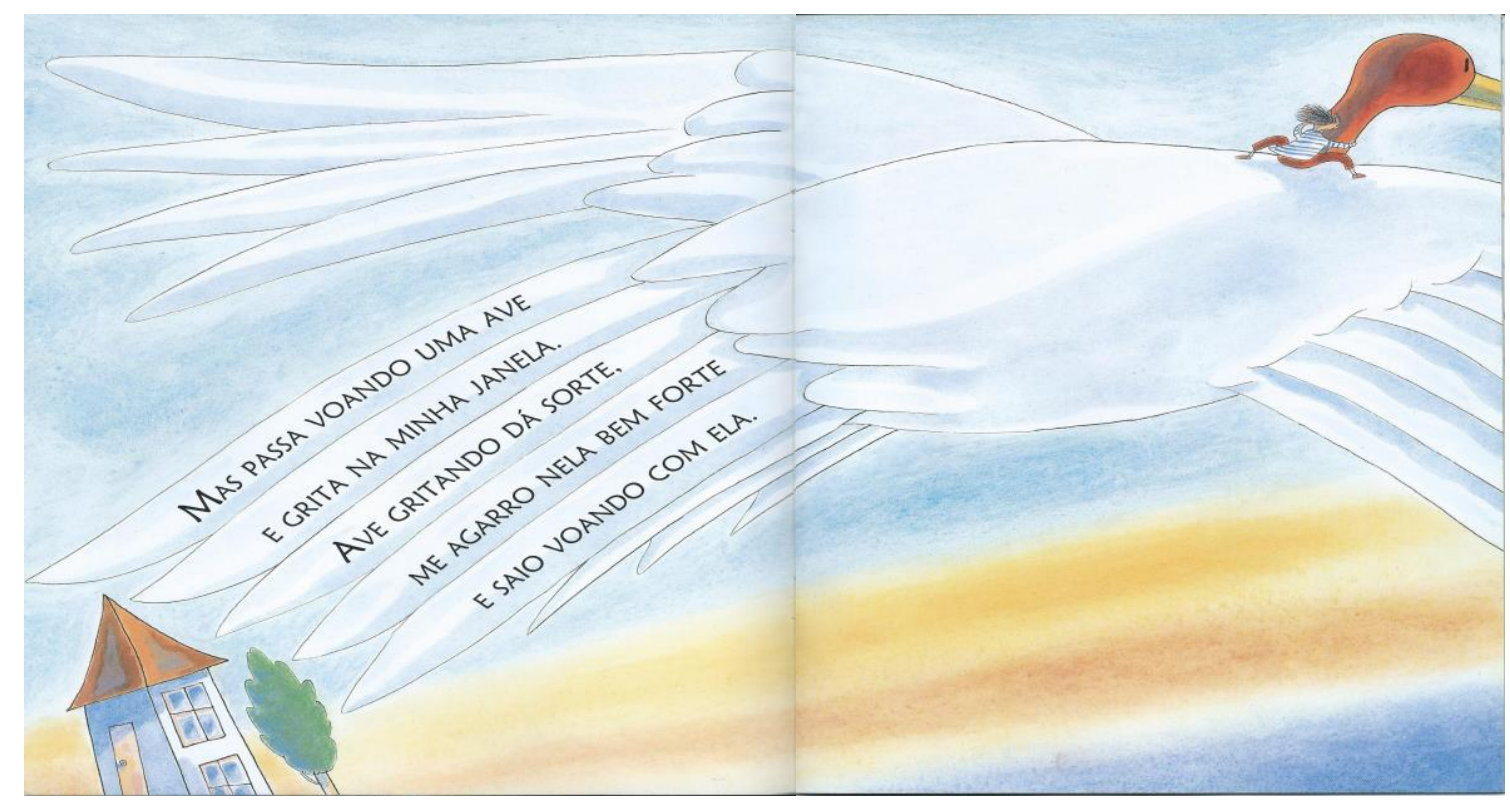

Figura 4.7. Ilustração de Helena Alexandrino para o livro Vi uma Estrela lá fora, de Regina Chamlian.

Em seu voo, a ave anuncia o horizonte para além do livro. O texto verbal compõe as plumagens de sua asa esquerda. O menino agarrado ao seu pescoço aceita o convite para a nova aventura. O grito da ave simboliza a voz do mundo a nos chamar para a vida.

Ao virar a página, temos mais um momento de introspecção:

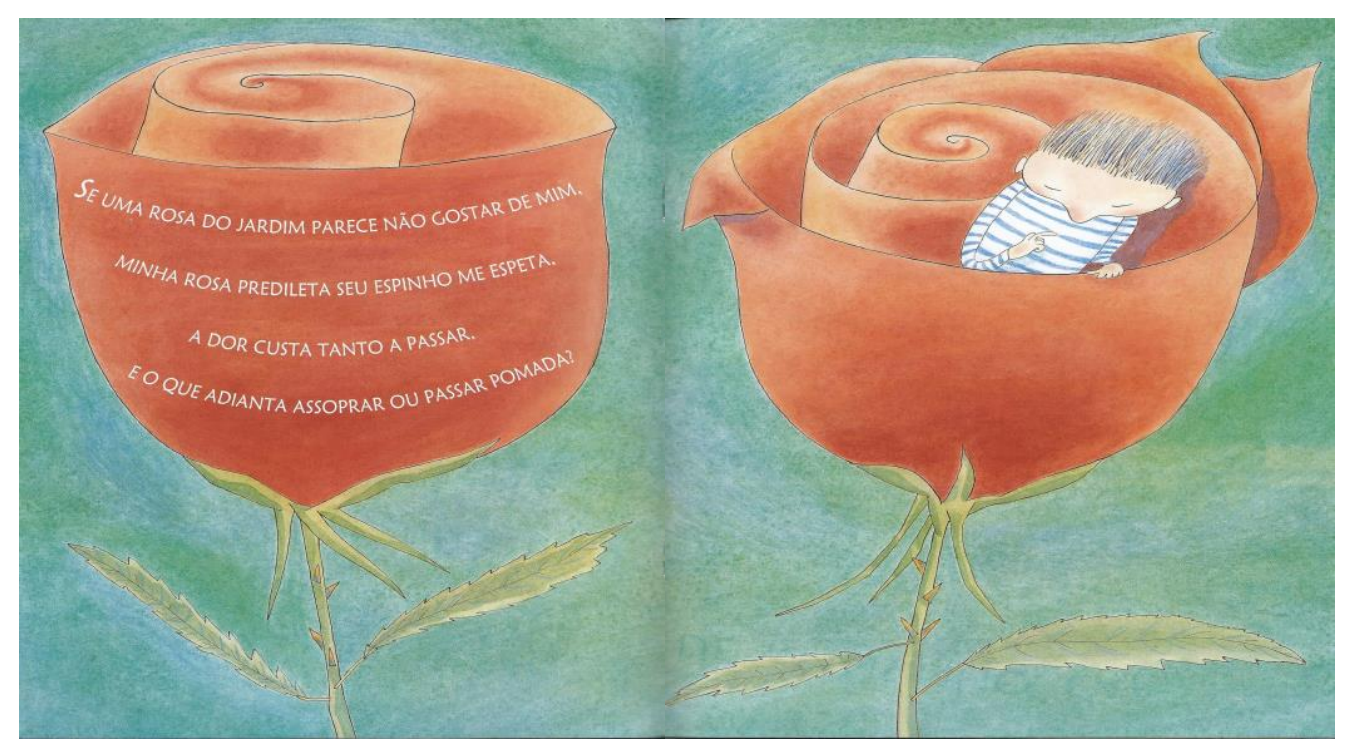

Figura 4.8. Ilustração de Helena Alexandrino para o livro Vi uma Estrela lá fora, de Regina Chamlian. 
Dentro do botão de rosa, o menino olha seu dedinho indicador; ele sente dor. Aqui a mensagem aponta para o fato de haver quem não goste da gente e, até mesmo quem gosta, quem nos é predileto, pode nos machucar, e não há o que fazer para passar a dor, nem soprar, nem passar pomada... e é na próxima página que vem a solução para todos os dodóis da criança.

Na sequência, mais uma vez, temos um texto que só poderá ser lido de ponta cabeça ou girando o livro em $360^{\circ}$ graus. Novamente e de forma mais nítida, as palavras envolvem o menino como o ventre materno. O texto verbal simboliza os limites deste ventre. Não há nada melhor que carinho e uma fala mansinha para nos consolar, para aliviar nossas dores. Carinho é melhor que pomada para cicatrizar as feridas.

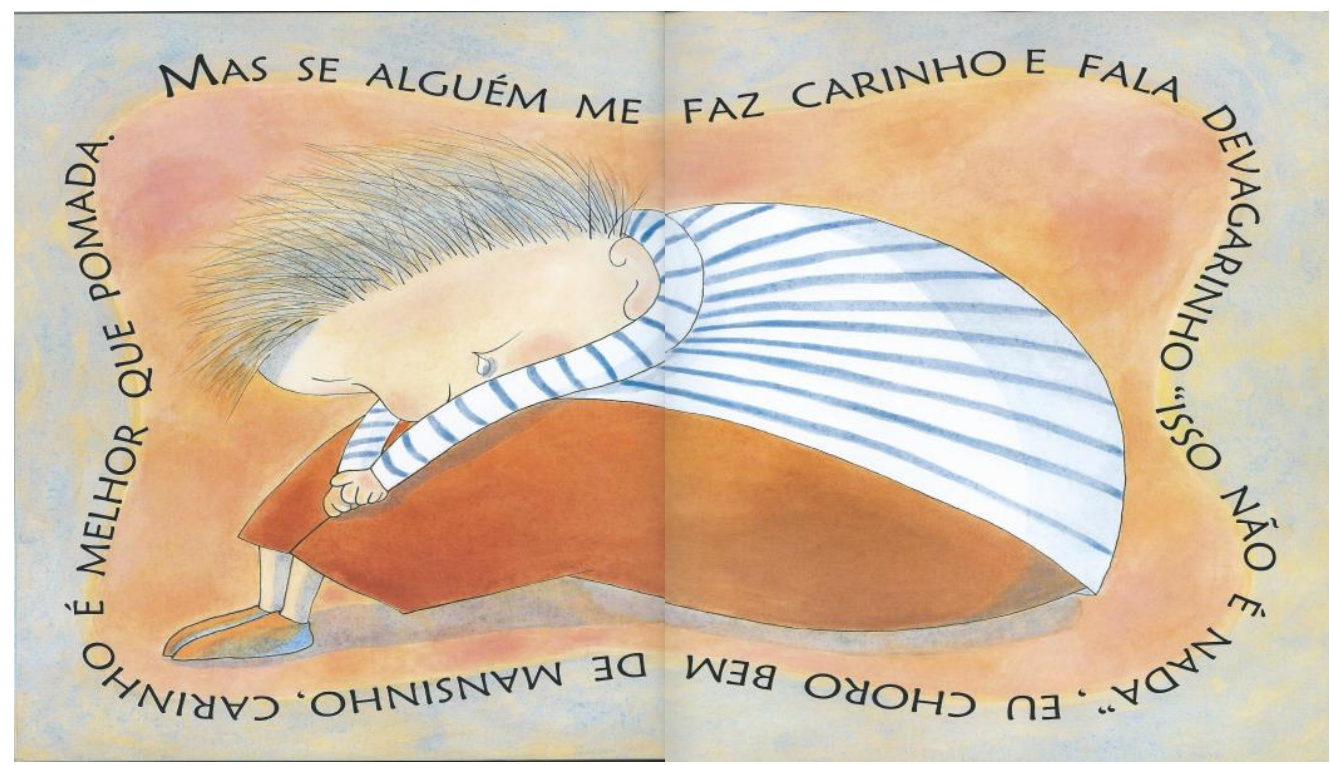

Figura 4.9. Ilustração de Helena Alexandrino para o livro Vi uma Estrela lá fora, de Regina Chamlian.

As imagens visuais em consonância com as imagens verbais nos levam para o aconchego do ventre materno. A imagem que surge é a da mãe grávida que 
acaricia sua barriga e fala devagarinho com a criança que carrega em seu ventre e que nem sempre tem pressa para nascer. Escondida do mundo e protegida pelo amor de sua mãe, não se sente só. Momento único em nossas vidas em que não pertencemos a nós mesmos, somos parte de outro alguém.

Ao virar a página do livro, a ilustração remete novamente ao ventre, desta vez simbolizado pela caixa. O menino aparece em movimento. Ele quer entrar dentro da caixa, se esconder, voltar para o aconchego do ventre materno, não quer nascer.

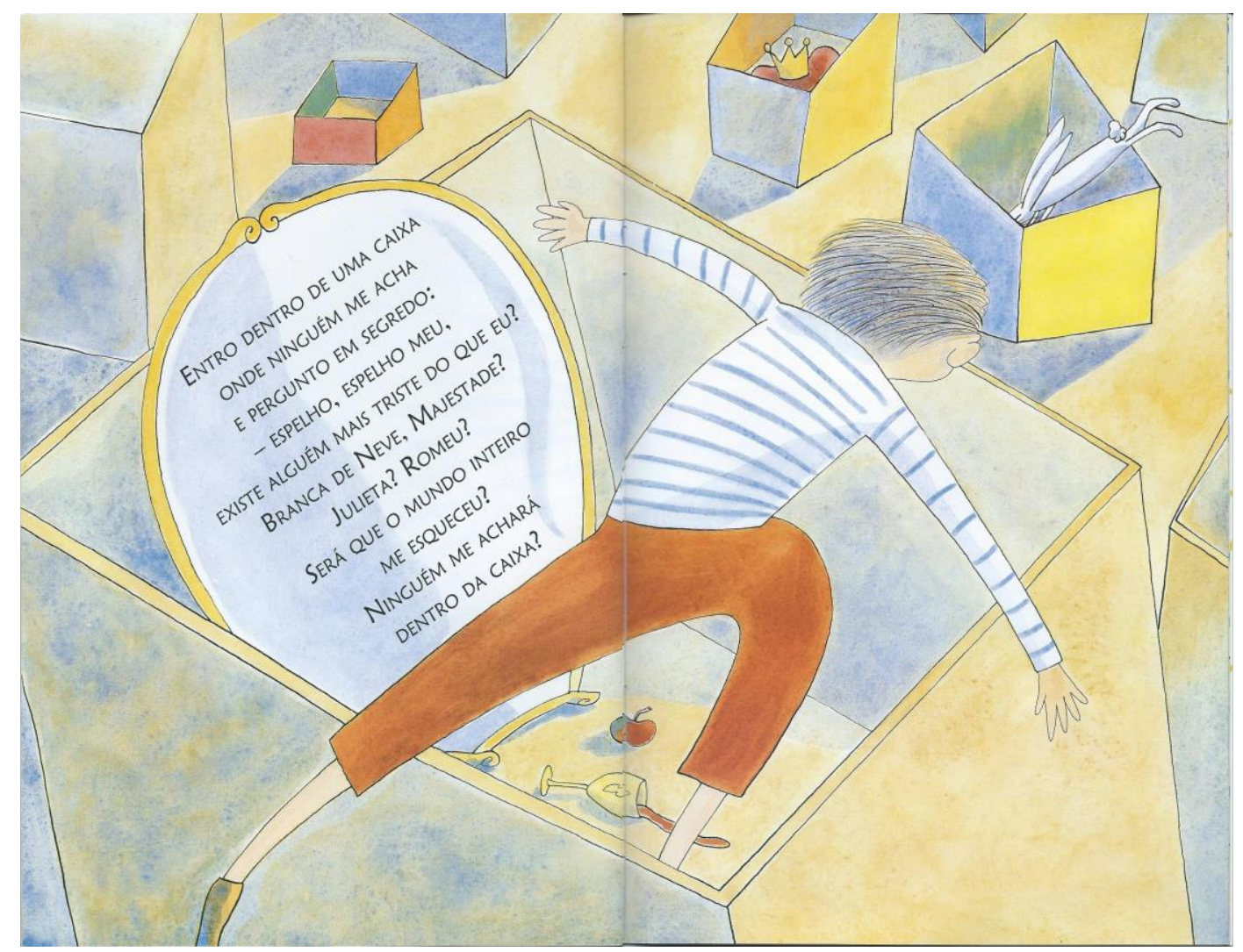

Figura 4.10. Ilustração de Helena Alexandrino para o livro Vi uma Estrela lá fora, de Regina Chamlian.

A caixa, no dicionário de símbolos de Jean Chevalier e Alain Gheerbrant, é descrita como: 
Símbolo feminino, interpretado como uma representação do inconsciente e do corpo materno, a caixa sempre contém um segredo: encerra e separa do mundo aquilo que é precioso, frágil ou temível. Embora proteja, também pode sufocar (CHEVALIER, $2012: 164)^{90}$.

O texto verbal compõe a imagem no espelho que reflete as vozes e algumas personagens de outras estórias. Há uma transformação no sentido da frase tão conhecida do conto Branca de Neve; ao invés da beleza, o que preocupa o menino é a tristeza e a sensação de solidão, o mundo inteiro o esqueceu? As caixas menores também resgatam personagens de outras estórias: o rei simbolizado pela coroa sobre o pano vermelho, que provavelmente representa um manto; e, novamente, o coelho, que remete a Alice no País das Maravilhas.

Ao mesmo tempo em que se esconde na caixa, espera que alguém o resgate, o encontre. Fechado em seu interior quer emergir, quer que alguém o encontre e o tire dali, quer nascer.

Montanhas, arco-íris e texto verbal se mesclam, misturam-se, imbricam sentidos que abrem novas possibilidades de dizer, de pensar. Arco-íris/montanhas por onde o menino brinca, se equilibra, corre. E temos mais uma vez uma ilustração que ultrapassa os limites materiais do livro, na figura do coelho que ultrapassa os limites da página.

Esta parte também é muito rica em simbologia, "mas olhando pouco além do meu espelho" simboliza o quanto é importante parar de olhar para o próprio umbigo e enxergar o mundo, o Outro, a vida que está aí para ser vivida, antecipando o que será contado a seguir.

${ }^{90}$ [grifos do autor]. 


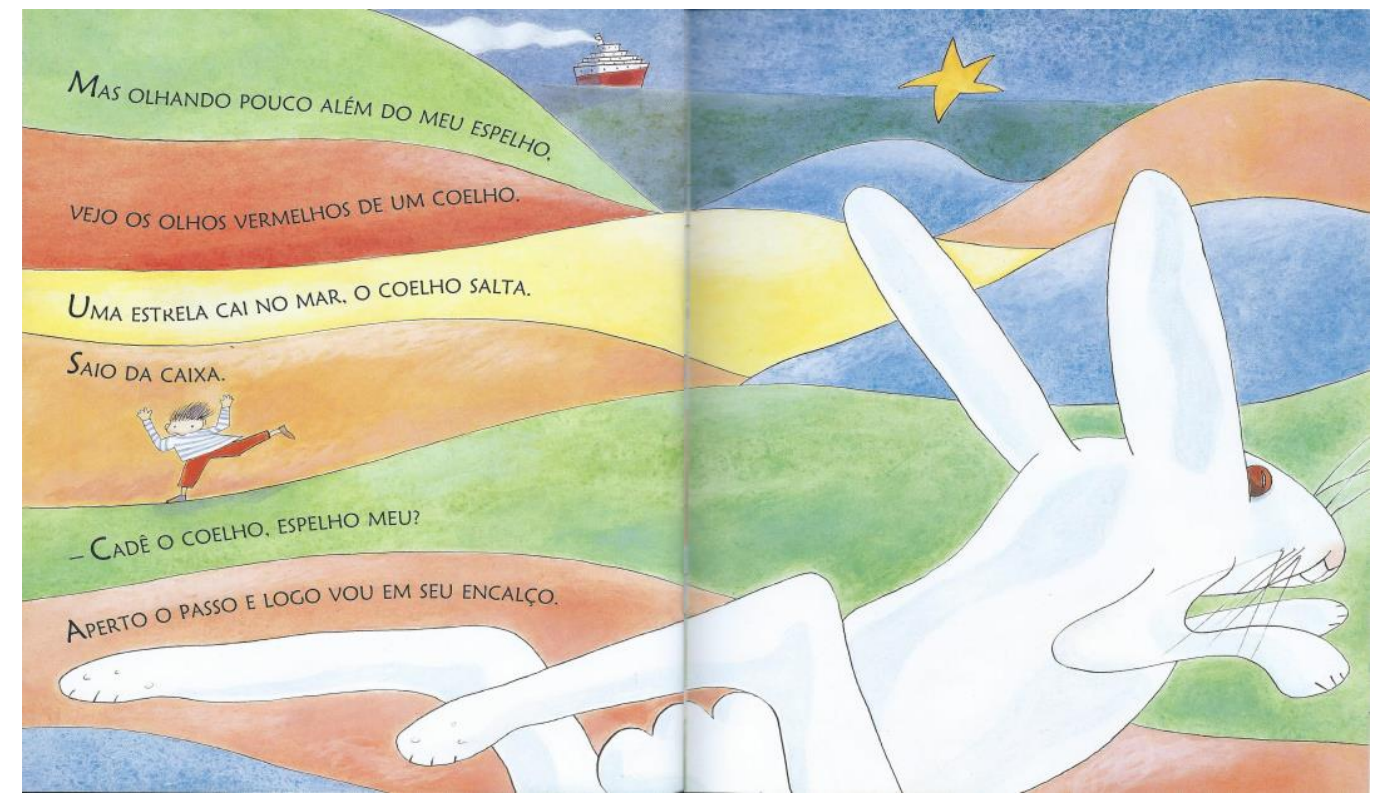

Figura 4.11. Ilustração de Helena Alexandrino para o livro Vi uma Estrela lá fora, de Regina Chamlian.

Deitado de barriga para cima, enrolado que nem lombriga, com partes do seu corpo para fora do livro, o menino fita seu umbigo.

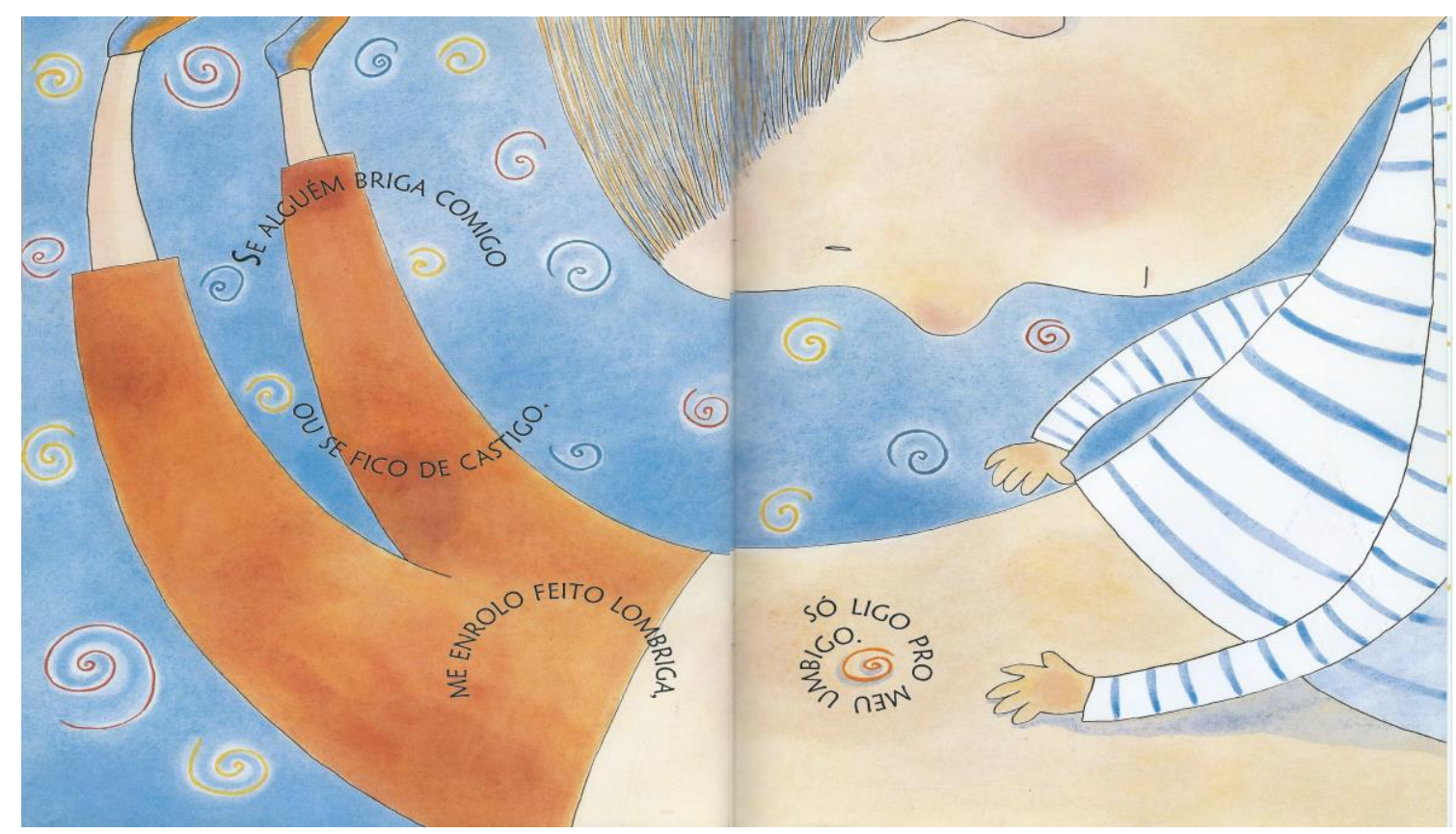

Figura 4.12. Ilustração de Helena Alexandrino para o livro Vi uma Estrela lá fora, de Regina Chamlian. 
O texto verbal é quebrado em quatro partes que se compõe a partir de um semicírculo, quase círculo na junção das primeiras duas partes, outro semicírculo e um caracol. Novamente é preciso revirar os olhos ou girar a página em 360 graus para a leitura do texto que se enrosca no umbigo do menino. Verbal e visual tecendo a narrativa que se enrola em si mesma.

O movimento espiral está presente no texto, na ilustração, nas palavras, como um pensamento que se perde em si mesmo, como o corpo que se enrola tentando se proteger do mundo. Mais uma vez aparece a tristeza, desta vez associada ao castigo sofrido, que faz com que o menino se volte, novamente, para dentro de si mesmo.

As ilustrações das duas últimas páginas dão a impressão de não estarem conectadas. O fundo é branco, o que difere de todas as demais páginas.

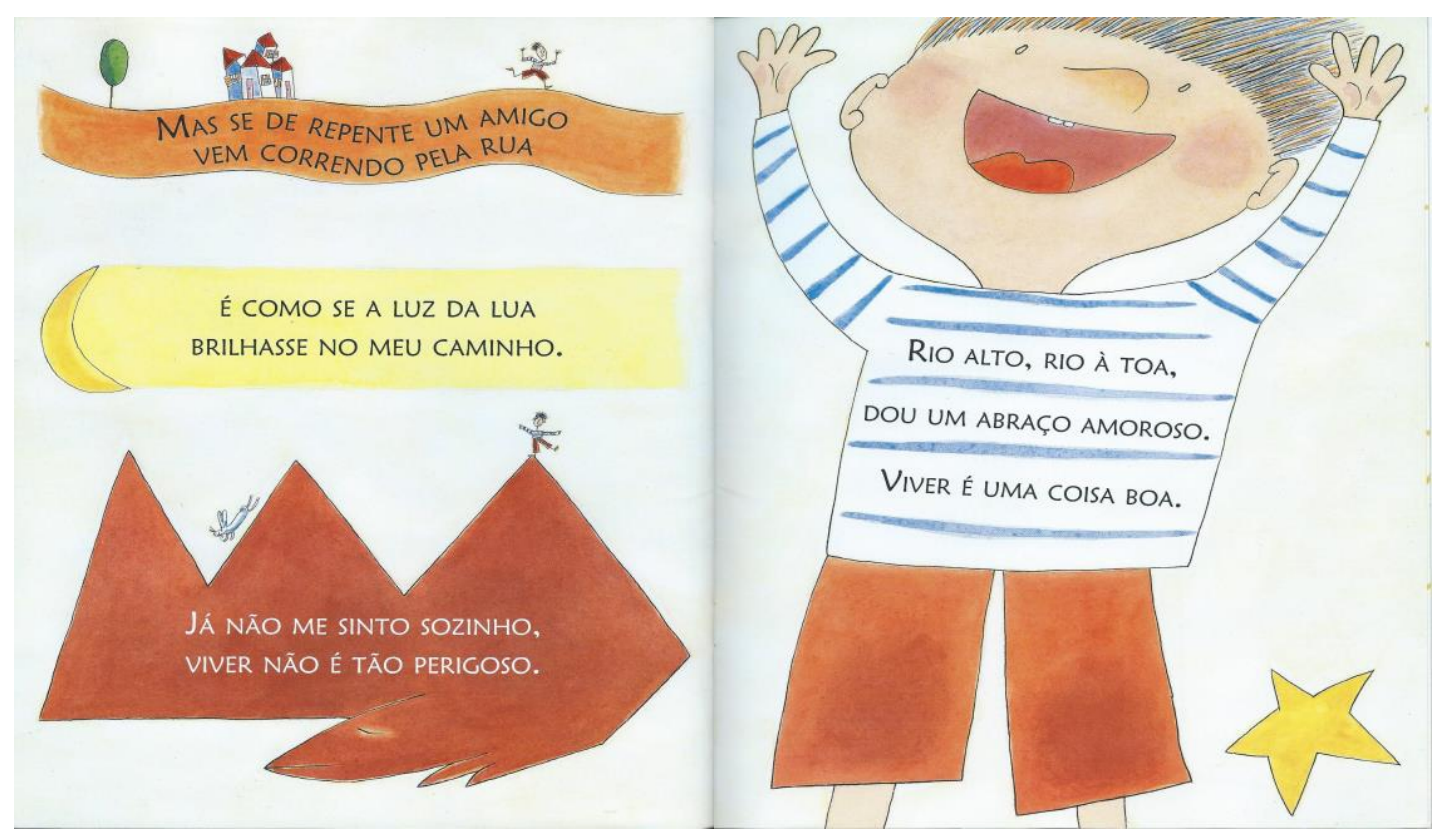

Figura 4.13. Ilustração de Helena Alexandrino para o livro Vi uma Estrela lá fora, de Regina Chamlian. 
As três ilustrações da página esquerda parecem independentes entre si. A conexão se dá pelo texto verbal e pelo visual que se concretiza em concomitância com o verbal. Em outras palavras, a princípio não reconhecemos a rua como rua; a primeira impressão é a de que é uma faixa. Só após a leitura do texto verbal é que fica claro que se trata de uma rua. Mais uma vez, o signo remete para um significado que é reformulado em outro signo por meio do texto: "Mas de repente um amigo vem correndo pela rua". O amigo também se confunde com o próprio personagem da estória que em todas as ilustrações vestia a mesma camisa branca com listas azuis e o mesmo calção vermelho. Como o menino está trajando roupa semelhante, só entendemos que não é o menino após a leitura do texto que está dentro da faixa, que não é faixa, é uma rua.

A rua está acima da lua e do facho de luz que ilumina o caminho do menino, invertendo a posição do céu e da terra. O amigo do texto verbal, também pode ser o cão da ilustração, que tem em seu dorso a natureza representada por três montanhas, nas quais podemos ver novamente o coelho de Alice e o menino amigo. E é dentro do corpo do cachorro que o texto verbal diz: "Já não me sinto sozinho. Viver não é tão perigoso". Multiplicidade de sentidos e representações do signo amigo.

A estória termina com o menino ocupando a última página inteira, sendo que seus cabelos espetados e parte das suas pernas estão para fora, não cabem no livro que é pequeno demais para os limites da fantasia, do viver. O menino está feliz. É a primeira ilustração em que seus olhos e bocas estão abertos. Seus braços estão para o alto como que comemorando. Há uma estrela amarela na parte inferior direita da página, a mesma que apareceu na capa e na página das montanhas com o arco- 
íris. O texto está dentro do menino, disposto na blusa branca entre as listas azuis e diz: "Rio alto, rio à toa, dou um abraço amoroso. Viver é uma coisa boa". De olhos e braços aberto, o menino nasceu e encarou a vida, com seus mistérios e aventuras, buscando reencontrar em seus amigos a sensação de proteção do ventre materno.

A estória não termina aí. Basta fechar o livro que nos deparamos com mais uma ilustração e mais uma mensagem. Mensagem que remete aos componentes da estória e nos traz o amigo gatinho, representado no lugar que um dia o menino esteve:

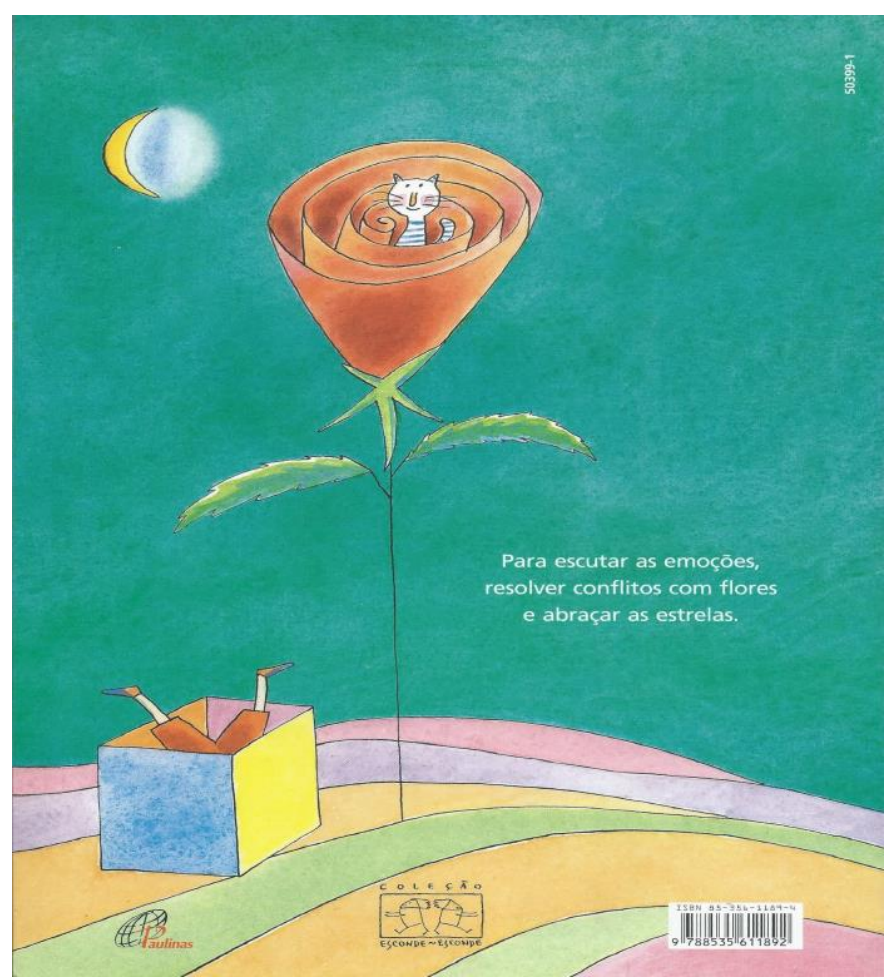

Figura 4.14. Ilustração de Helena Alexandrino para o livro Vi uma Estrela lá fora, de Regina Chamlian.

Neste texto, autora e ilustradora, fazem representar a criança com seus pensamentos, seus desejos, angústias e medos, analisando a dificuldade de viver 
pelo viés infantil. Trazendo à tona a criança que vive dentro de cada um de nós. Criança que tem vontade de se esconder, que sente dor, que chora, sente rejeição, mas também sente alegria, ri, se encanta com as belezas naturais, quer brincar, ter amigos, correr, ser feliz.

Somos pegos pelo estético, que coloca em risco a própria categorização infantil, como nos explicam Maria José Palo e Maria Rosa D. Oliveira:

(...) ao se falar dos textos de literatura infantil sob a dominante estética, põe-se em risco a própria categorização de infantil e, mais ainda, do possível gênero de literatura infantil, já que não se trata mais de falar a esta ou àquela faixa etária de público, mas assim de operar com determinadas estruturas de pensamento - as associações por semelhança - comuns a todo ser humano (PALO, 2006:12)

O texto permitirá ao nosso jovem adulto abandonar por alguns momentos o pensar puramente racional e voltar a pensar por meio de imagens, como quando começou a desvendar o mundo. Pensar por analogia, nutrido pelas imagens verbais e visuais propostas no livro Vi uma estrela lá fora e seguindo o conselho proposto na última ilustração: "para escutar as emoções, resolver conflitos com flores e abraçar as estrelas". Além disso, possibilitará vivenciar o Eu na figura do menino e o corpo astral, ou corpo das sensações, proposto por Steiner.

\subsubsection{A raposa e o cavalo}

A raposa e o cavalo é um dos contos da coletânea dos Irmãos Grimm. A 
versão escolhida por nós está no volume dois da coleção de oito volumes publicada pela editora Edigraf, em 1961. A tradução é de Íside M. Bonini e ilustrações de Ramirez. Embora o conto escolhido não tenha nenhuma ilustração.

Como a maioria dos contos, começa com "Era uma vez..." anunciando que deixaremos o mundo real para adentrar no mundo maravilhoso. Ao emprestar a voz aos animais, por meio do chamado animalismo, o conto nos transporta para fora do espaço e do tempo em que vivemos. Desta forma, libertos da realidade do aqui e agora, do que nos é externo, entramos no mundo dos sonhos, da magia, da imaginação. Mergulhamos nesse mundo com toda a nossa alma e somos envolvidos pela voz que transcende.

A escolha deste conto em particular, se deu por meio da temática da velhice, como contraponto ao primeiro poema escolhido por nós: "Pobre Vovô!". Ao mesmo tempo em que atende a proposta de Steiner com relação aos contos dos Irmãos Grimm, sendo que este conto em particular é protagonizado por animais, facilitando a incorporação do corpo astral, que é o corpo que temos em comum com os animais.

A estória fala de um camponês que possuía um cavalo que sempre trabalhou com dedicação e Ihe foi muito útil. Porém, com o passar do tempo o cavalo ficou velho e deixou de ter utilidade. Seu dono não queria mais alimentá-lo nem Ihe dar abrigo, por isso pediu que ele fosse embora. Admitiu gostar muito dele, mas disse que ele só poderia voltar se ainda tivesse força para lhe trazer um leão.

O cavalo ficou muito triste e partiu para a floresta cabisbaixo. Lá encontrou uma raposa que quis saber o motivo de tanta tristeza. O cavalo explicou que a avareza de seu dono fez com que ele o enxotasse de casa esquecendo-se de todos 
os anos em que ele Ihe serviu, enquanto ainda era jovem e tinha forças para puxar o arado com rapidez. A raposa perguntou: "sem uma palavra de consolação?". O cavalo explicou que "a consolação foi magra", já que o camponês lhe impôs a tarefa de levar-lhe um leão sabendo que ele não teria força suficiente para isso.

A raposa resolveu ajudar o cavalo e pediu que ele se deitasse no chão, imóvel, fingindo-se de morto. O cavalo obedeceu e a raposa saiu em busca de um leão que morava lá perto. A raposa disse ao leão que havia um cavalo morto perto dali. Se o leão a seguisse poderia ter um farto almoço.

Lá chegando, convenceu o leão que seria melhor amarrar o rabo do cavalo nas suas pernas para que ele pudesse voltar à sua toca e ter mais comodidade e tranquilidade para a refeição. O leão aceitou. A raposa amarrou as pernas do leão com o rabo do cavalo e, antes que o leão percebesse o que estava acontecendo, a raposa bateu nas costas do cavalo e gritou: “Upa, meu alazão; puxa, puxa!".

Rapidamente o cavalo se levantou e saiu arrastando o leão que rugia tão alto que assustou todos os pássaros da floresta. O cavalo não se intimidou com o rugido, continuou arrastando o leão, com um pouco de dificuldade, até a casa do camponês.

O camponês surpreso recebeu o cavalo e prometeu-lhe que nada lhe faltaria. Alimentou-o com fartura e cuidou dele até a sua morte.

Como a maioria dos contos de fada, A raposa e o cavalo, coloca um problema existencial de forma breve e categórica: o cavalo envelheceu, já não tem mais serventia para seu dono, por isso foi expulso de sua cocheira. Coloca também as questões do bem e do mal representados por meio dos personagens e de suas ações: o camponês infiel, que apesar de toda a fidelidade do cavalo ao longo de sua vida de trabalho o expulsa, personifica o mal; a raposa, que decide ajudar o cavalo, 
personifica o bem. E é sua astúcia que irá ajudar o cavalo a resolver seu problema. Inicia-se, assim, a luta estabelecida pela maioria dos contos de fada: o cavalo deve lutar por sua sobrevivência e vencer um obstáculo - levar um leão para o seu dono e, assim, reconquistar seu lar. Somos levados a sofrer com o cavalo, com suas atribulações e triunfamos ao voltar para casa carregando o leão!

Quem nos ajuda a justificar o valor literário de um conto de fadas é Bettelheim:

O prazer que experimentamos quando nos permitimos ser suscetíveis a um conto de fadas, os encantamentos que sentimos não vêm do significado psicológico de um conto (embora isto contribua para tal) mas das suas qualidades literárias - o próprio conto como uma obra de arte. O conto de fadas não poderia ter seu impacto psicológico sobre a criança se não fosse primeiro e antes de tudo uma obra de arte (BETTELHEIM, 1980:20).

E ele também inclui o adulto, que é quem queremos sensibilizar com as leituras literárias propostas nesta pesquisa:

Os contos de fada são ímpares, não só como uma forma de literatura, mas como obras de arte integralmente compreensíveis para a criança, como nenhuma outra forma de arte o é. Como sucede com toda grande arte, o significado mais profundo do conto de fadas será diferente para cada pessoa, e diferente para a mesma pessoa em vários momentos de sua vida. A criança extrairá significados diferentes do mesmo conto de fadas, dependendo de seus interesses e necessidades do momento. Tendo oportunidade, voltará ao mesmo conto quando estiver pronta a ampliar os velhos significados ou substituí-los por novos (BETTELHEIM, 1980:20-21). 
O conto proposto traz a rejeição e a superação dessa rejeição. Traz a utilidade do jovem e a desvalorização do velho. Enfim, significados profundos com os quais queremos confrontar os jovens que farão parte de nossa pesquisa.

\subsubsection{O príncipe cavalinho}

A estória $O$ príncipe cavalinho contada por Jesuína Pereira Magalhães ${ }^{91}$, é uma das estórias que compõem a obra "Contos e fábulas do Brasil" organizada por Marco Haurélio ${ }^{92}$ e com ilustrações de Severino Ramos. O conto escolhido por nós não apresenta nenhuma ilustração. A obra traz estórias de vários contadores do sertão baiano. O livro é divido em oito partes: Contos de animais, Contos maravilhosos, Contos religiosos, Contos novelescos, Contos do Ogre (Diabo), Contos Jocosos (Facécias), Contos de fórmula e Contos não Classificados. A classificação dos contos e as notas explanatórias são de Paulo Correia ${ }^{93}$ que considera:

\footnotetext{
Uma das grandes vantagens dos contos de tradição oral ao serem classificados segundo normas universais é poderem facilmente ser comparados a outras versões existentes dentro de um país ou entre países diferentes.
}

\footnotetext{
91 Jesuína Pereira Magalhães (1915-2013), conhecida como Dona Zuzinha, nasceu em Igaporã na Bahia. Contadora de histórias, benditos, cantigas e romances.

${ }^{92}$ Marco Haurélio Fernandes Farias nasceu em um vilarejo chamado Ponta de Serra, município de Riacho de Santana, Bahia, em 1974. Graduado em Letras pela Universidade do Estado da Bahia (UNEB) é cordelista, poeta e pesquisador do folclore brasileiro e da literatura de cordel.

${ }^{93}$ Paulo Correia nasceu em Faro, no extremo sul de Portugal, em 1966. Formou-se em Antropologia, em Lisboa. Integra, desde 1997, o Centro de Estudos Ataíde Oliveira, fundado dois anos antes por Isabel Cardigos e Dias Marques, com o objetivo de recolher, tratar e divulgar a literatura de tradição oral portuguesa, através da revista internacional E.L.O. É responsável pela constituição, classificação e atualização do arquivo de versões, base de dados e catálogos (em inglês e português) que resumem a parte conhecida da tradição contista portuguesa (alargada recentemente a toda a área lusófona graças à inclusão de um acervo substancial de versões africanas e brasileiras).
} 
Todos os contos desta coletânea foram classificados de acordo com o catálogo internacional ATU, com exceção dos que nele não figuram, classificados com a ajuda de catálogos regionais (Contos e fábulas do Brasil, 2011:198).

Paulo Correia explica que O príncipe cavalinho está catalogado como ATU 433 A (O rei Lindorm $)^{94}$ e que há onze versões portuguesas e seis versões brasileiras desta estória. A versão brasileira escolhida, segundo ele, é a que mais se aproxima das versões portuguesas. O conto é apresentado na seção dos Contos Maravilhosos.

Marco Haurélio faz uma breve introdução antes da apresentação de cada seção e fala de cada um dos contos que serão apresentados. Na apresentação dos Contos Maravilhosos ele explica que "esta segunda seção reúne os contos maravilhosos (fairy tales), contos de fadas ou de encantamentos (...)" (Contos e fábulas do Brasil, 2011:35). Com relação à estória ele explica que:

(...) O príncipe cavalinho é daquelas histórias cuja origem é difícil precisar, embora a personagem título lembre as divindades zoomórficas, ou antropozoomórficas que o Cristianismo tardio associará a uma maldição a ser quebrada. Só assim entendemos a razão de um rei enviar, sem opor muita resistência, suas três filhas, a um noivo que é parte do tempo um homem e a outra parte um cavalo. O enredo rememora um rito sacrifical, do qual o motivo do noivo animal parece derivar. Lindolfo Gomes colheu a variante mineira em que o príncipe, involuntariamente amaldiçoado, nasce sob a forma de um leitão (Contos e fábulas do Brasil, 2011:37-38).

\footnotetext{
94 ATU, Hans Jörg Uther: The Types of International Folktales. A Classification and Bibliography. 3 vols. (FF Communications 284-286.) Helsinki: Academia Scientiarum Fennica, 2004.
} 
A estória começa com "Houve, em outros tempos..." que já nos transporta para fora do nosso tempo real, tempo em que vivemos. O conto é sobre uma rainha que queria muito ter filhos, porém não conseguia engravidar. Ela inveja todos que poderiam ter filhos, inclusive os animais. Passava horas admirando um potrinho que pastava em frente ao palácio. Diz a estória que: "deve ter proferido alguma blasfêmia ao meio-dia, porque, de uma hora para outra, apareceu de bucho". O próprio rei estranhou o fato, mas alegrou-se com a novidade. Porém, quando a criança nasceu, teve início a maldição: a criança era ora príncipe, ora cavalo. Apesar de ficarem tristes, rei e rainha, "perceberam a mão da Providência punindo a impaciência e inveja da mãe".

No reino vizinho vivia um rei e suas três lindas filhas. A filha mais velha foi a primeira a avistar e se apaixonar pelo príncipe cavalinho. O rapaz correspondeu e logo foi pedir sua mão em casamento. O rei ficou muito preocupado, pois sabia do encanto, disse à filha: "não está certo você se casar com alguém que numa hora é gente e na outra é cavalo. O que as pessoas vão dizer?". A filha insistiu tanto que ele acabou aceitando.

Na noite de núpcias, o príncipe encarou a moça é perguntou-Ihe: "Você casou com um homem ou com um cavalo?" e ela respondeu: "Com um cavalo!". Neste instante, o príncipe se transformou em cavalo e matou a moça com uma patada.

A família quase morreu de tristeza. Mesmo assim, algum tempo depois, foi a filha do meio quem se apaixonou pelo príncipe. Ela também foi pedida em casamento. O pai relutou em aceitar, mas acabou cedendo e os dois se casaram. $\mathrm{Na}$ noite de núpcias, o príncipe fez a mesma pergunta e obteve a mesma resposta que resultou no mesmo desfecho. A filha do meio foi morta por uma patada. 
Os pais ficaram muito tristes e a tristeza foi ainda maior quando a filha caçula também quis se casar com o príncipe cavalinho. O rei perguntou se ela havia endoidado, disse que já havia perdido duas filhas e que não iria perder mais uma. Não adiantou nada. A filha esperneou, gritou até seu pai consentir. O pai sentenciou: "Minha filha, você vai morrer como suas irmãs!" e ela respondeu: "Se for esse o meu destino, meu pai..."

O casamento se realizou e, na noite de núpcias, o príncipe fez a mesma pergunta que havia feito às outras duas irmãs: "Você casou com um homem ou com um cavalo?", a moça respondeu: "Com um homem". A partir desse momento, foi quebrada a maldição e, de acordo com o texto, "os dois viveram felizes os anos em que Deus os conservou na terra".

O espaço em que ocorre a estória é o espaço sagrado no qual a Providência tem o poder de punir a impaciência e a inveja. Impaciência e inveja são sentimentos ruins que devem ser punidos, representam o Mal. A rainha é punida por seu comportamento, que traz para o conto as dicotomias: Bem e Mal. A punição se dá pela maldição da metamorfose: seu filho ora é príncipe, ora animal. Como animal, ele é cruel, mata suas duas primeiras esposas que não foram capazes de quebrar o encanto. É necessário ver o homem, o príncipe, para que o encanto seja quebrado. E é a terceira filha que consegue quebrar o encanto ao afirmar que casou com um príncipe e ao aceitar sem resistência seu destino ("Se for esse o meu destino, meu pai..."). E, mais uma vez, temos os valores religiosos presentes na narrativa, já que foi Deus o responsável pelo "viveram felizes para sempre", que, na estória, se transforma em "os dois viveram felizes os anos em que Deus os conservou na terra". A escolha desta obra se deu por dois motivos: em primeiro lugar, por ser um 
conto maravilhoso e, em segundo lugar, por ser um conto que valoriza as imagens religiosas, a providência divina, que vai de encontro à proposta de Rudolf Steiner de apresentar narrativas deste tipo aos jovens. A estória propicia a integração do corpo astral com o corpo etérico, sendo o primeiro representado pelo animal e o segundo pelo homem.

\subsubsection{O Beijo da Palavrinha}

A obra $O$ Beijo da Palavrinha, de Mia Couto ${ }^{95}$, com ilustrações de Malangatana ${ }^{96}$, é um dos títulos da Coleção Mama África, publicada no Rio de Janeiro em 2006. A poeticidade da obra é explicada pelos próprios organizadores desta coleção:

$\mathrm{Na}$ África, a arte de contar histórias continua viva. Com a Coleção Mama África pretendemos resgatar contos tradicionais africanos, recriados por alguns dos mais importantes escritores do continente e ilustrados por nomes igualmente sonoros das artes plásticas. Livros, portanto, que juntam arte e literatura, tradição e modernidade. Livros para crianças, mas também para seus pais. Livros para colecionar.

O Beijo da Palavrinha conta a estória de Maria Poerinha, uma menina pobre que vivia em uma aldeia "tão interior que acreditavam que o rio que ali passava não tinha nem fim nem foz". Seu sonho era ver o mar. Ela tinha um único irmão que se

\footnotetext{
${ }^{95}$ Mia Couto nasceu em 1955, na cidade da Beira, em Moçambique. Biólogo, contista, poeta e romancista, é um dos mais notáveis autores contemporâneos de língua portuguesa.

96 O pintor Malangatana Valente Ngwenya (1936-2011) nasceu em Matalana, Moçambique. Antes de se estabelecer como pintor, foi pastor de gado, aprendiz de nyamussoro (médico tradicional), babá e acompanhador de bolas num clube de tênis. Considerado o mais importante artista plástico de Moçambique, suas obras integram coleções de museus por todo o mundo.
} 
chamava Zeca Zonzo. Como o segundo nome já anuncia, ele era desprovido de juízo, meio tonto.

A estória não revela a idade da menina, embora as ilustrações apontem para uma moça com o corpo já bem formado. Enfim, não há como saber. Mas, Maria Poeirinha adoeceu e "num instante, ela ficou vizinha da morte". Seu tio Jaime Litorânio estava na aldeia visitando a família nessa época. Ele morava perto do mar, fato implícito em seu segundo nome, e não se conformava com o fato de seus familiares nunca terem visto o mar. Ao ver a menina tão doente, Jaime Litorânio decidiu que deviam colocá-la num barco e levá-la o mais rápido possível à costa. Segundo ele, seria uma forma dela renascer e "descobrir outras praias dentro dela".

Mas a menina estava tão fraca que a viagem não foi possível. A família se reuniu ao redor da cabeceira de sua cama sem saber o que fazer. Foi quando Zeca Zonzo anunciou que iria lhe mostrar o mar. Ele apanhou uma caneta e uma folha de papel em branco e, contrariando a expectativa de todos, que achavam que ele iria desenhar o mar, ele escreveu "MAR" em letras bem gordas. Segurou os dedos magros de sua irmã, que já não conseguia ler, e conduziu-os por cima das letras que desenhara.

A princípio, a menina reclamou que só tocava sombras, por isso ele soprou seus dedos para corrigir qualquer defeito e ensiná-los "a decifrar a lisa brancura do papel". Foi assim que acompanhou com o dedo da menina a letra "m" escrita no papel, perguntando-Ihe que letra era aquela, ao que ela respondeu que era um "m". E assim, em plena comunhão, os dois irmãos desvendaram juntos as ondas do mar representadas pelas formas da letra "m", a gaivota pousada nela própria representada pela letra "a" e a rocha representada pela letra "r" dura e rugosa que 
magoaram os dedos da menina.

A família, que a princípio desaprovou a maluquice de Zeca Zonzo, vendo a comunhão e alegria dos dois irmãos, acabou aderindo à sua fantasia. Tio Jaime pediu silêncio à todos e com os olhos mareados disse: "Calem-se todos: já se escuta o marulhar!". E foi nessa atmosfera que Maria Poerinha faleceu tocando e ouvindo o mar.

Optamos por apresentar a obra completa devido à riqueza e profundidade das ilustrações e à forma como o texto verbal cria efeitos visuais e sonoros.

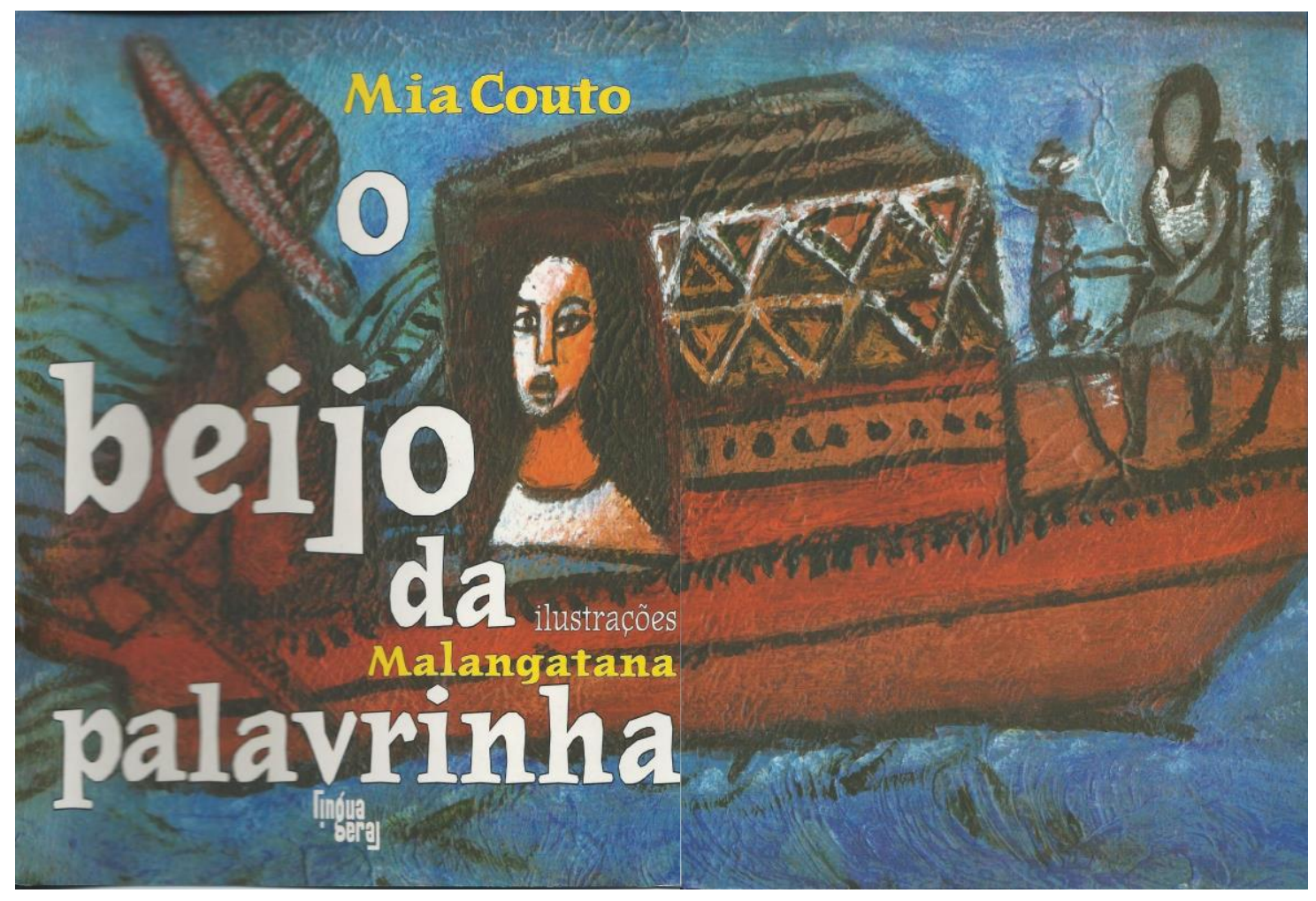

Figura 4.15. Ilustração de Malangatana para a capa/contracapa do livro O Beijo da Palavrinha, de Mia Couto.

A estória começa com "Era uma vez..." que sugere que iremos deixar o mundo real, concreto, para adentrarmos no mundo da fantasia. Mas o texto verbal 
coloca "Era uma vez" em um tamanho de letra que diminui sua importância e nos apresenta o motivo principal da estória em letras garrafais: "uma menina que nunca vira o mar":

E a brincadeira com o texto verbal continua, apresentando a personagem principal do tamanho de uma poeira: "Chamava-se Maria Poerinha". Novamente as letras aumentam, porém sem ultrapassar o tamanho das letras que colocam a problemática da estória, para nos apresentar a família e as condições em que viviam na aldeia. A ilustração traz os habitantes da aldeia, nativos de pele avermelhada como a cor da terra, com olhos e bocas grandes, trajando quase nada, alguns enfeitados com cocares e colares de diferentes tipos.

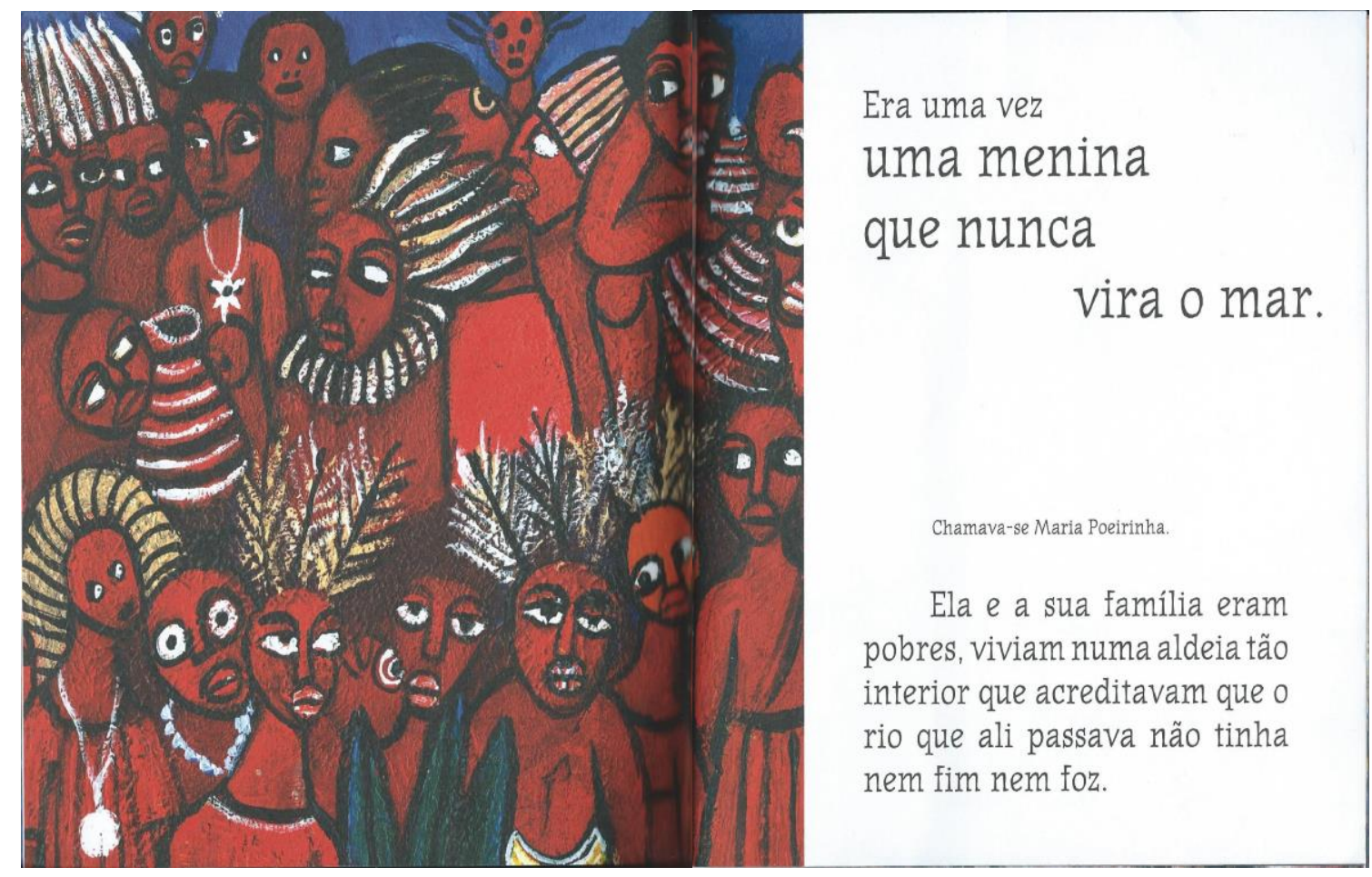

Figura 4.16. Ilustração de Malangatana para a obra O Beijo da Palavrinha, de Mia Couto.

A brincadeira com o texto verbal continua na página seguinte para dizer que 
"Poeirinha só ganhará um irmão," o Zeca Zonzo, que é apresentado em letras maiores. Em seguida, as letras voltam ao tamanho inicial para dizer "que era desprovido de juízo. Cabeça sempre no ar, as ideias lhe voavam como" e aumentam para dizer "balões" diminuindo novamente para explicar que são balões "em final de festa" simbolizando os balões que se perdem no ar. A ilustração nos traz imagens que resgatam a África presente em nosso imaginário.

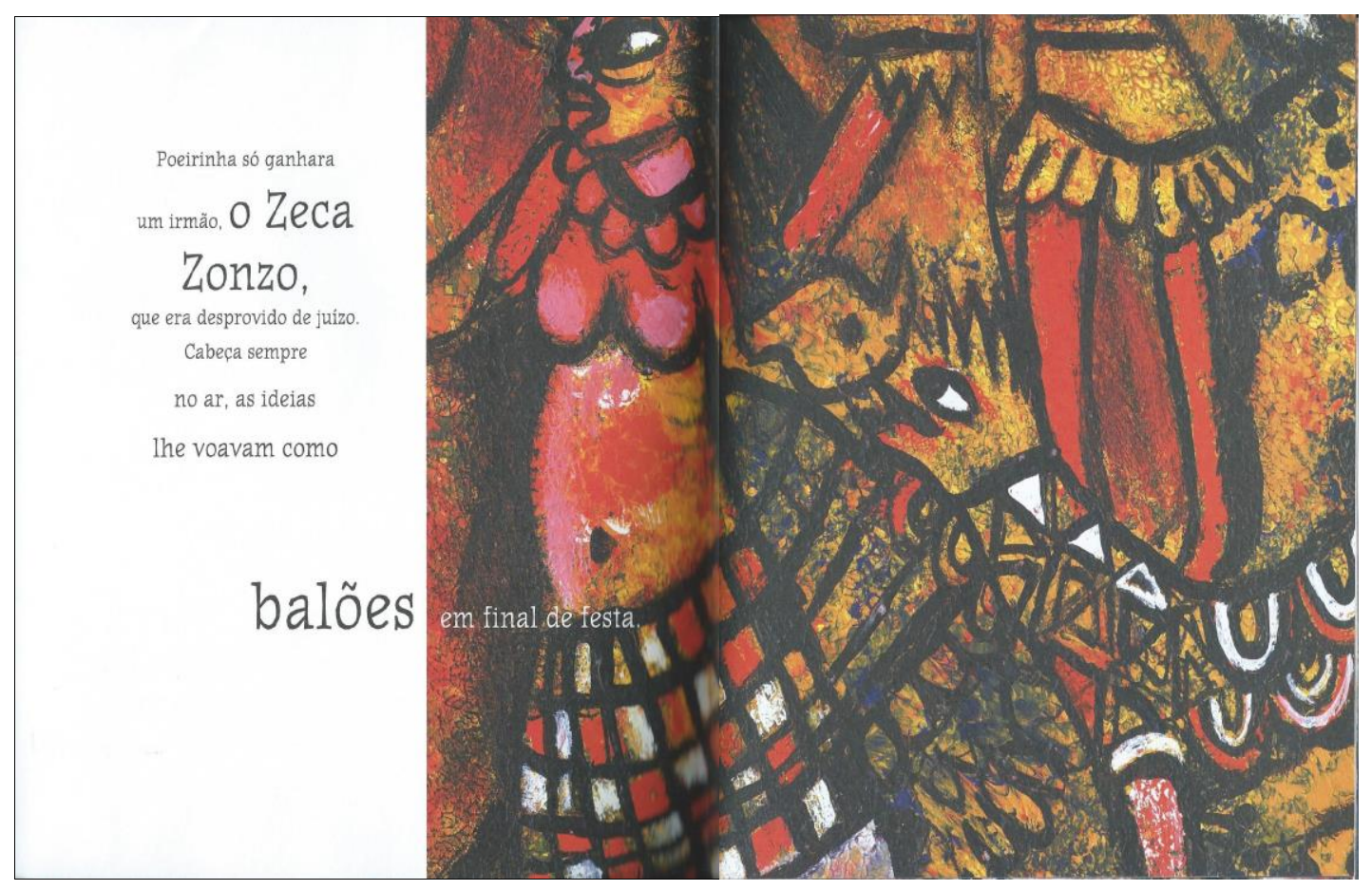

Figura 4.17. Ilustração de Malangatana para a obra O Beijo da Palavrinha, de Mia Couto.

Não é possível identificar Zeca Zonzo na ilustração. Na verdade, ao final do livro, são apresentadas telas do pintor Malangatana e descobrimos que esta ilustração é uma parte do quadro intitulado "A princesa arrastando o manto": 


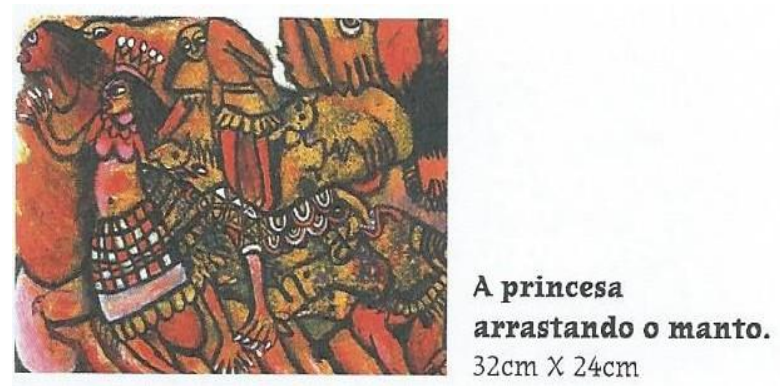

Figura 4.18. Quadro "A princesa arrastando o manto" do pintor Malangatana.

A ilustração antecipa o que será contado a seguir, sem que o leitor se dê conta disso. E nem é necessário, pois a arte não deve ser explicada, deve ser admirada, sentida. E a cada encontro, uma nova descoberta, um novo encantamento, um novo significado virá à tona.

Voltando ao livro, temos as imagens dos sonhos de Poerinha expressas na ilustração. O texto continua brincando com o leitor:

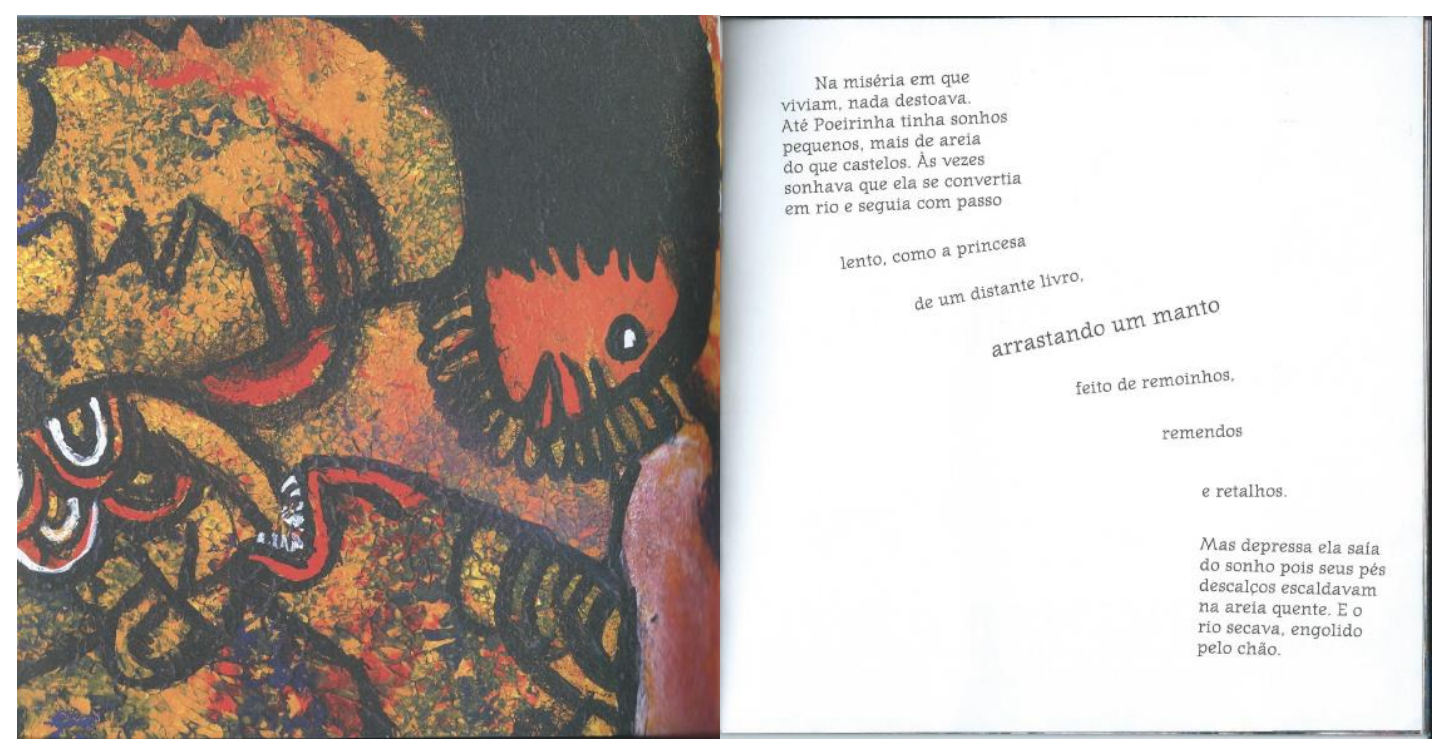

Figura 4.19. Ilustração de Malangatana para a obra O Beijo da Palavrinha, de Mia Couto.

O texto verbal diz em letras menores que: "Na miséria em que viviam, nada 
destoava. Até Poerinha tinha sonhos pequenos, mais de areia do que de castelos. Ás vezes sonhava que ela se convertia em rio e seguia com passo" e, neste instante, o texto verbal, se transforma em texto visual ao simbolizar os movimentos do rio "lento, como a princesa de um distante livro" e as letras aumentam um pouco para dizer "arrastando um manto", transformando o rio visual construído pelo texto verbal em manto de princesa. Em um misto simbólico de rio e de manto, o texto continua seu percurso e se completa "feito de redemoinhos, remendos e retalhos". O texto se completa assumindo a materialidade dura do local de Poerinha: "Mas depressa ela saía do sonho pois seus pés descalços escaldavam na areia quente. E o rio secava, engolido pelo chão". Rio e princesa engolidos pela aridez do local de nascimento e vivência da personagem principal da estória.

Maria Poerinha é constituída pelo texto que descreve seus sonhos pequenos como poeira, ao mesmo tempo em que descreve a realidade dura da terra quente da aldeia em que vivia, capaz de secar (ou engolir) o rio (ou os sonhos de princesa).

A ilustração que aparece ao virar a página é apenas uma parte do que será apresentado na página subsequente:

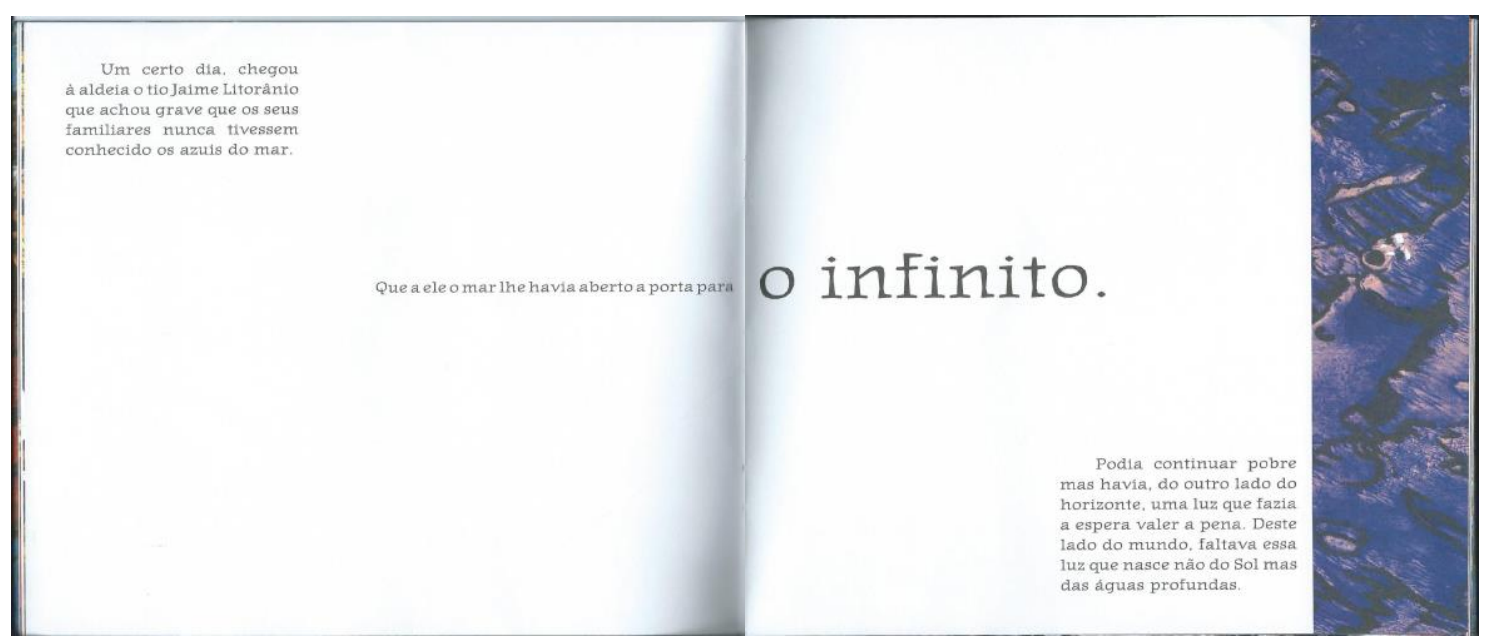

Figura 4.20. Ilustração de Malangatana para a obra O Beijo da Palavrinha, de Mia Couto. 
A ênfase textual é dada em "o infinito", mais uma vez o texto verbal adquire sonoridade.

O texto começa no canto superior esquerdo dizendo: "Um certo dia, chegou à aldeia o tio Jaime Litorânio que achou grave que os seus familiares nunca tivessem conhecido os azuis do mar". Azuis já anunciados na ilustração que traz também os mistérios, as sombras, as profundezas do mar. No canto inferior direito da página o texto diz: "Podia continuar pobre mas havia do outro lado do horizonte, uma luz que fazia a espera valer a pena. Deste lado do mundo, faltava essa luz que nasce não do Sol mas das águas profundas". A oposição significada pela mensagem textual é simbolizada na forma como o texto verbal se dispõe na página dupla. No centro das duas páginas aparece escrito o que o mar fez por tio Jaime: "Que a ele o mar lhe havia aberto a porta para o infinito".

E, ao virar a página, temos o infinito do mar:

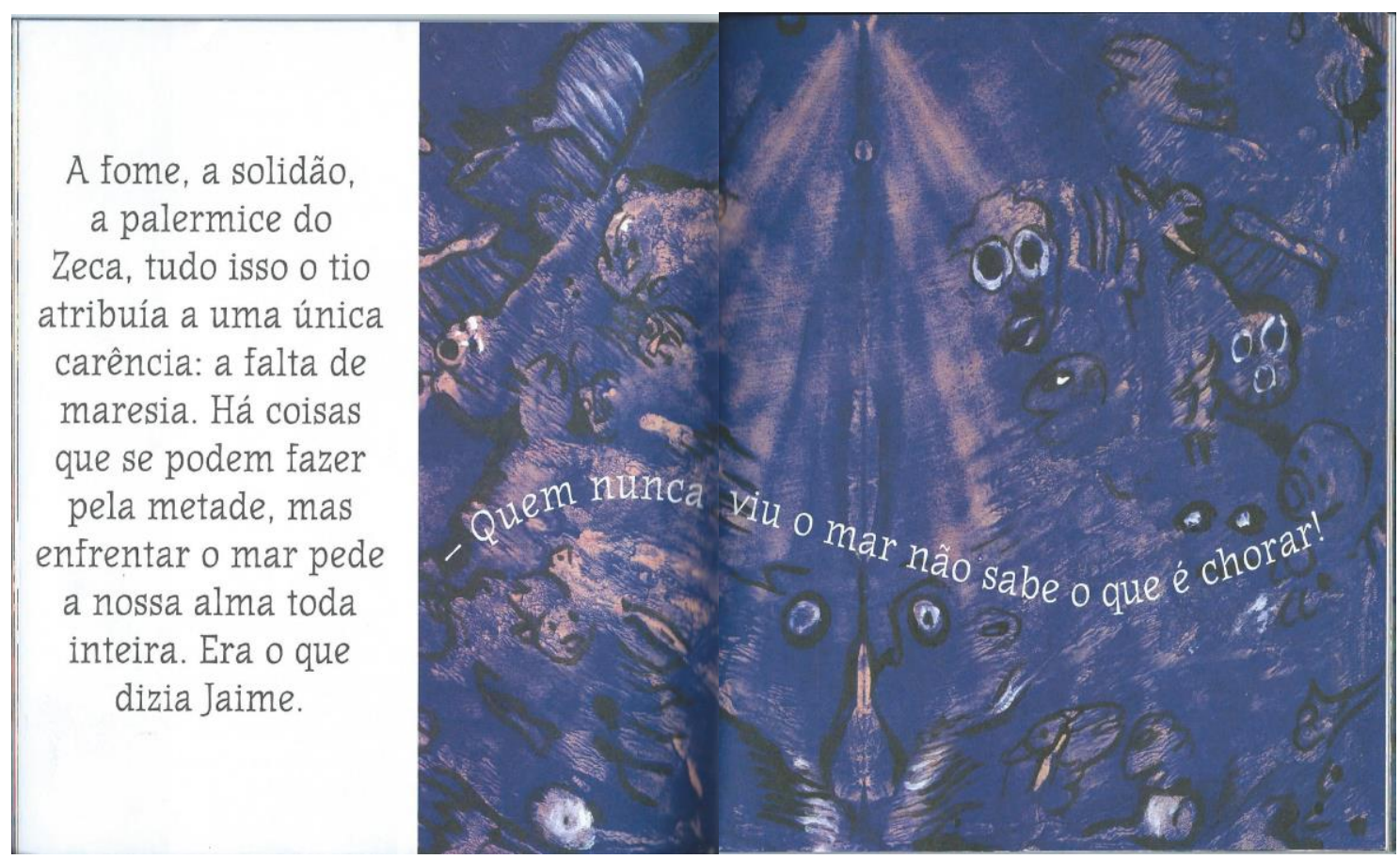

Figura 4.21. Ilustração de Malangatana para a obra O Beijo da Palavrinha, de Mia Couto. 
E os problemas enfrentados pela família de Poerinha, inclusive a palermice de seu irmão, são justificados por Tio Jaime Litorâneo pela ausência do mar em suas vidas, pela carência de maresia. Eles jamais seriam inteiros, pois só no enfrentamento com o mar, que eles sequer conheciam, é que nossa alma se torna inteira, completa. E parte do texto verbal se torna visual ao ser inserido na ilustração em movimento, como o movimento das águas do mar.

O mar, no dicionário de símbolos de Jean Chevalier e Alain Gheerbrant, é descrito como:

O símbolo da dinâmica da vida. Tudo sai do mar e tudo retorna a ele: lugar dos nascimentos, das transformações e dos renascimentos. Águas em movimento, o mar simboliza um estado transitório entre as possibilidades ainda informes as realidades configuradas, uma situação de ambivalência, que é a de incerteza, de dúvida, de indecisão, e que pode se concluir bem ou mal. Vai daí que o mar é ao mesmo tempo a imagem da vida e a imagem da morte (CHEVALIER, 2012:592).

É exatamente esta simbologia que será anunciada pelo texto verbal ao virarmos a página do livro:

Certa vez, a menina adoeceu gravemente. Num instante ela ficou vizinha da morte. $O$ tio não teve dúvida: teriam que a levar à costa.

- Para que se cure, disse ele.

Para que ela renascesse tomando conta daquelas praias de areia e onda. E descobrisse outras praias dentro dela.

- Mas o mar cura assim tão de verdade?

- Vocês não entendem?, respondia ele. 
A continuação do texto verbal aparece em letras maiores e é possível lê-la na figura apresentada na próxima página.

O estado transitório (vida e morte) e as pistas do texto verbal (salvadora viagem) já anunciam o que vai acontecer... E o texto verbal assume a sonoridade de um grito: "Não há tempo a perder".

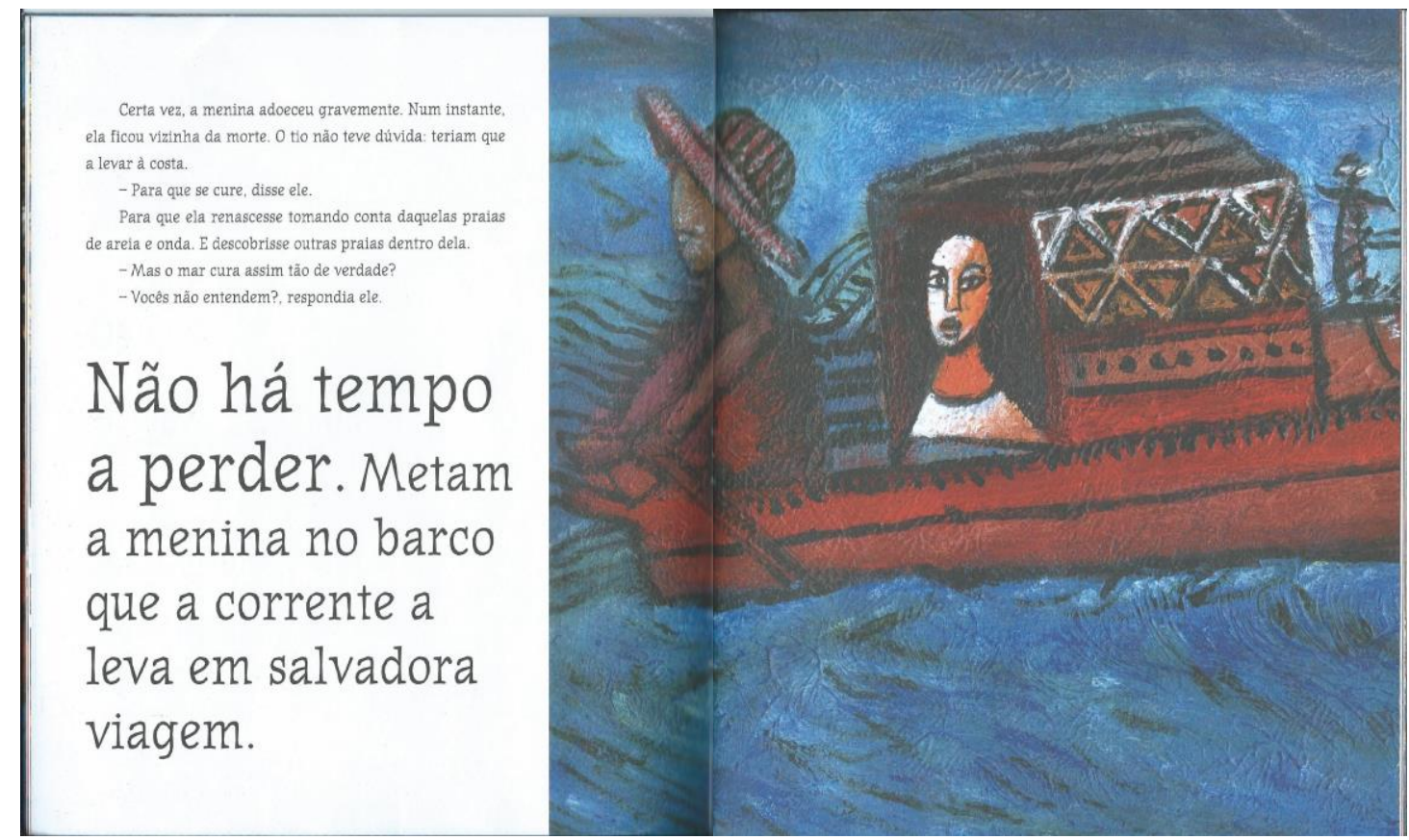

Figura 4.22. Ilustração de Malangatana para a obra O Beijo da Palavrinha, de Mia Couto.

Mas a viagem não foi possível devido à fraqueza da menina e o texto verbal descreve aquele estado em que nos vemos diante da morte de alguém e da falta do que dizer nestas situações:

Contudo, a menina estava tão fraca que a viagem se tornou impossível. Todos se aproximaram da cabeceira e ali ficavam sem saber o que fazer, sem saber o que dizer. A mãe pegou nas mãos da 
menina e entoou as velhas melodias de embalar. Em vão. A menina apenas ganhava palidez e o seu respirar era o de um fatigado passarinho. Já se preparavam as finais despedidas quando" ...

Neste ponto o texto verbal assume sua forma visual ao descer pela página como se estivesse correndo a anunciar: "o irmão Zeca Zonzo trouxe um papel e uma caneta".

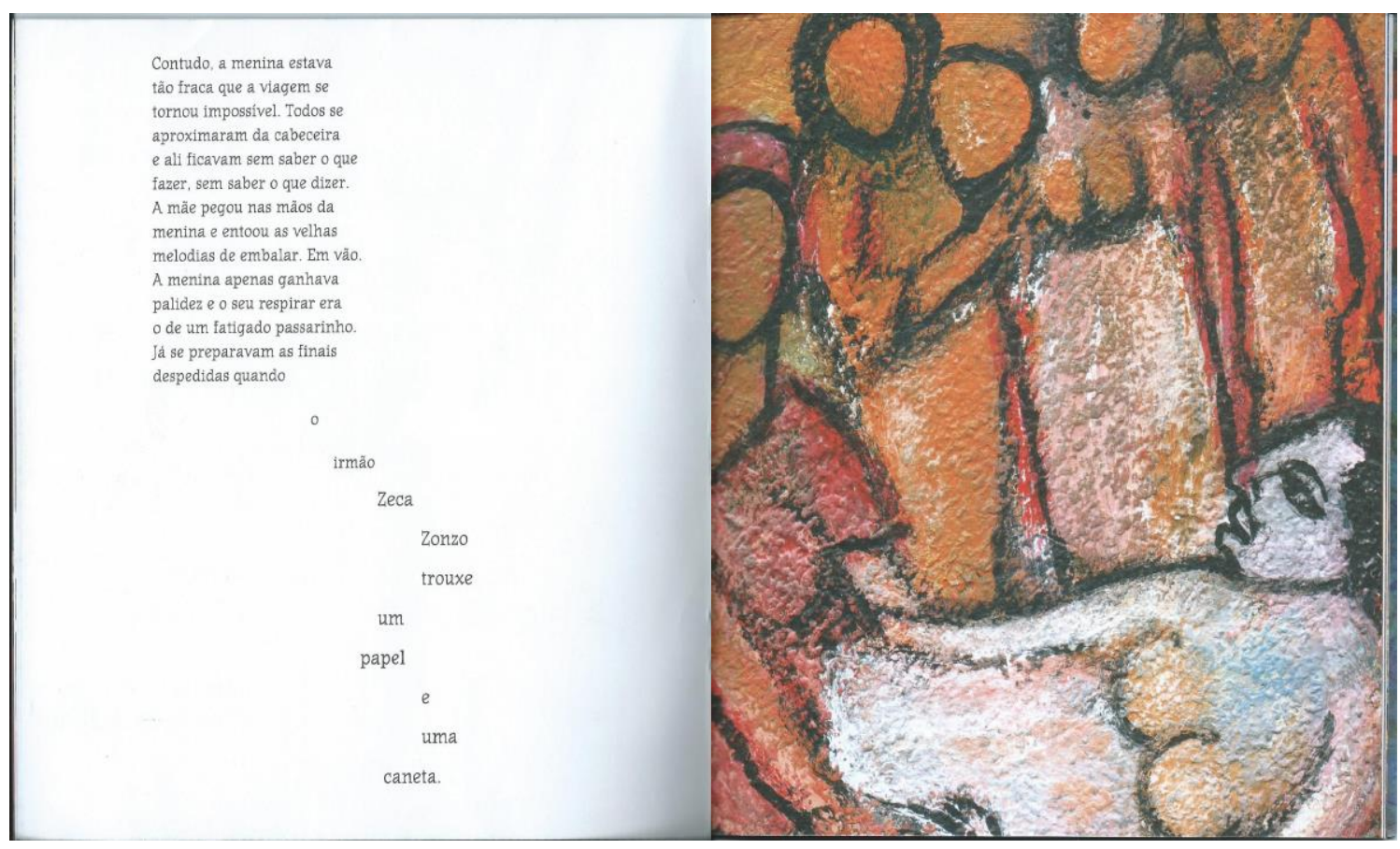

Figura 4.23. Ilustração de Malangatana para a obra O Beijo da Palavrinha, de Mia Couto.

E é Zeca Zonzo quem anuncia: "Vou-lhe mostrar o mar, maninha". E, novamente, o texto verbal é apresentado em letras menores para informar ao leitor que:

Todos pensaram que ele iria desenhar o oceano. Que iria azular o papel e no meio da cor iria pintar uns peixes. E o Sol em cima, como 
vela em bolo de aniversário. Mas não. Zonzo apenas rabiscou com letra gorda a palavra "mar". Apenas isso: a palavra inteira e por extenso.

O menino ficou olhando para a folha parecendo que não entendia o que ele mesmo escrevera. Antes que dissesse alguma coisa, a irmã murmurou, em débil suspiro:"

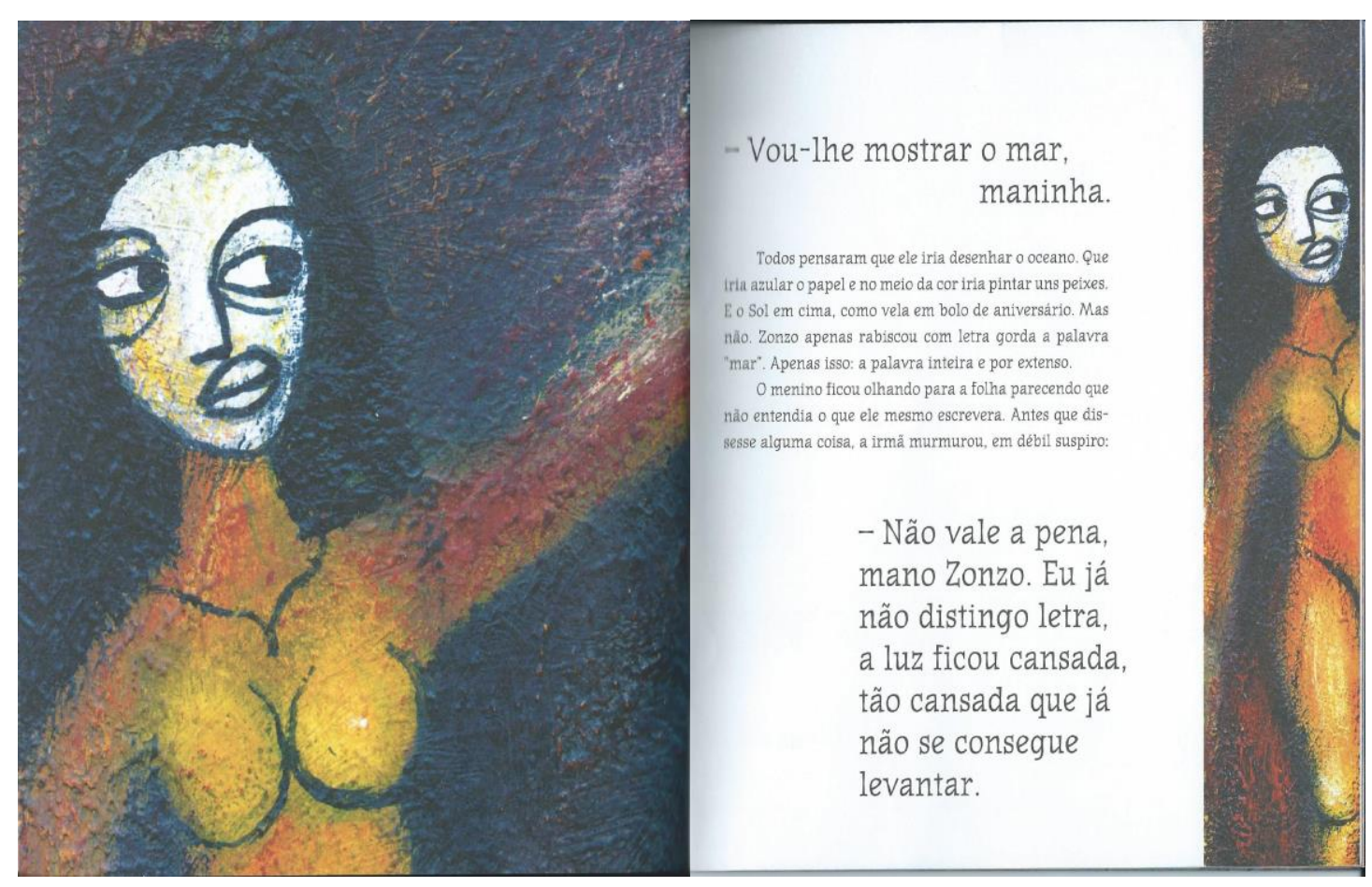

Figura 4.24. Ilustração de Malangatana para a obra O Beijo da Palavrinha, de Mia Couto.

As letras aumentam para contar ao leitor o que Maria Poerinha disse. Ela já não distinguia letra e explica que: "a luz ficou cansada, tão cansada que já não se consegue levantar". A luz pode simbolizar a força vital da menina e o fato de não conseguir se levantar pode simbolizar a dificuldade em manter-se viva. A ilustração é apresentada nas duas extremidades da página dupla e tem a menina representada em ambos os lados, sua dupla presença pode simbolizar o estado transitório que 
enfrenta entre os dois lados da situação: vida e morte, sendo a morte representada pelo renascimento.

Zeca Zonzo se prontifica a conduzir seu dedo por cima do dela, não importa se ela não consegue distinguir as letras, poderá senti-las com a ajuda dos dedos do irmão. As letras do texto verbal diminuem para dizer que:

Os pais chamaram o moço à razão: ele que poupasse a irmã daquela tontice e que a deixasse apenas respirar. Mas Zeca Zonzo fingiu não escutar. Ele tomou nas suas mãos os dedos magritos de Maria Poeirinha e os guiou por cima dos traços que desenhara.

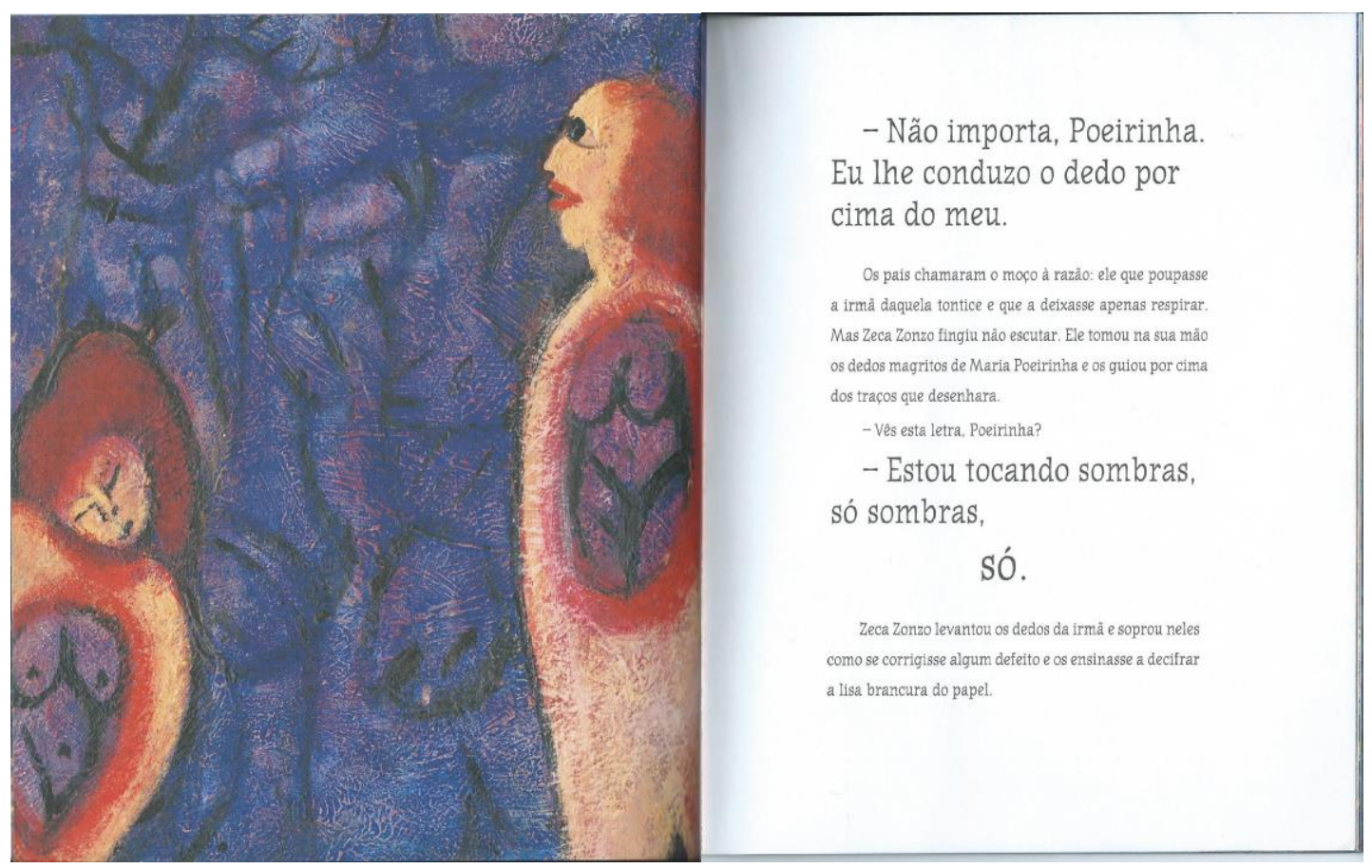

Figura 4.25. Ilustração de Malangatana para a obra O Beijo da Palavrinha, de Mia Couto.

A princípio, a menina não viu (sentiu) letra nenhuma; "tocou sombras, só sombras". É difícil ver sem poder usar nossos olhos. Não estamos acostumados. 
Porém, para Zeca Zonzo, era só uma questão de corrigir um defeito: "Zeca Zonzo levantou os dedos da irmã e soprou neles como se corrigisse algum defeito e os ensinasse a decifrar a lisa brancura do papel". E, ao virarmos a página, temos o seguinte diálogo:

- Experimente outra vez, mana. Com toda a atenção. Agora, já está sentindo?

- Sim. O meu dedo já está a espreitar.

- E que letra é?

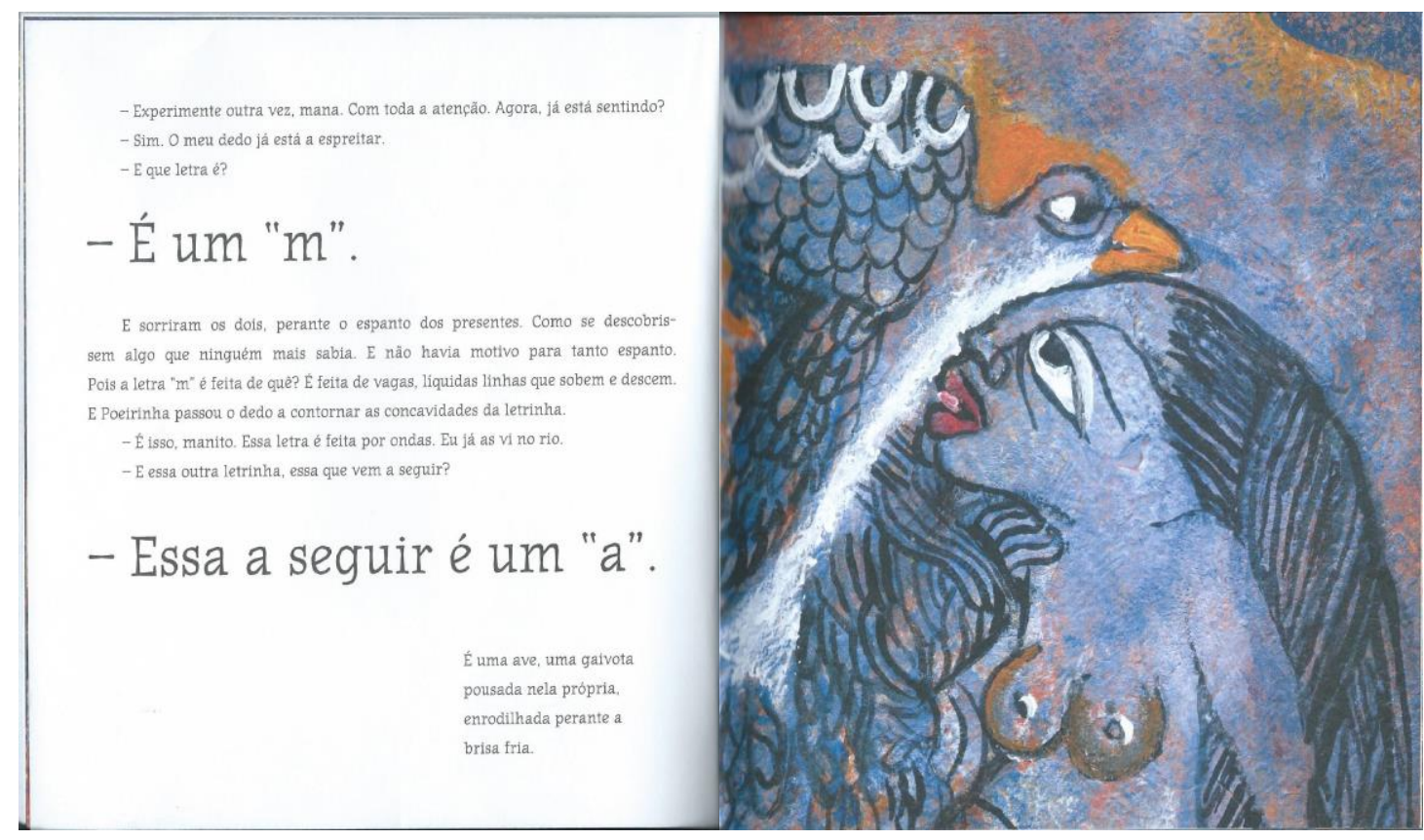

Figura 4.26. Ilustração de Malangatana para a obra O Beijo da Palavrinha, de Mia Couto.

$E$, assim, a menina aprendeu a ver por meio do sentir, identificando o "m" e depois o "a". Foi necessário prestar muita atenção para poder espreitar e sentir as letras. Mas, ao sentir o "m", um universo cheio de possibilidades se abriu diante da 
menina. Na ilustração, ela se imbrica com a ave e, juntas, simbolizam a letra "a". Juntos, em plena comunhão, os irmãos vão em busca da realização do sonho de Poerinha:

E sorriram os dois, perante o espanto dos presentes. Como se descobrissem algo que ninguém mais sabia. $E$ não havia motivo para tanto espanto. Pois a letra "m" é feita de que? É feita de vagas, líquidas linhas que sobem e descem. E Poeirinha passou o dedo a contornar as concavidades da letrinha.

- É isso, manito. Essa letra é feita por ondas. Eu já as vi no rio.

- E essa outra letrinha, essa que vem a seguir?

- Essa a seguir é um "a". É uma ave, uma gaivota pousada nela própria, enrodilhada perante a brisa fina.

A magia continua na página seguinte.

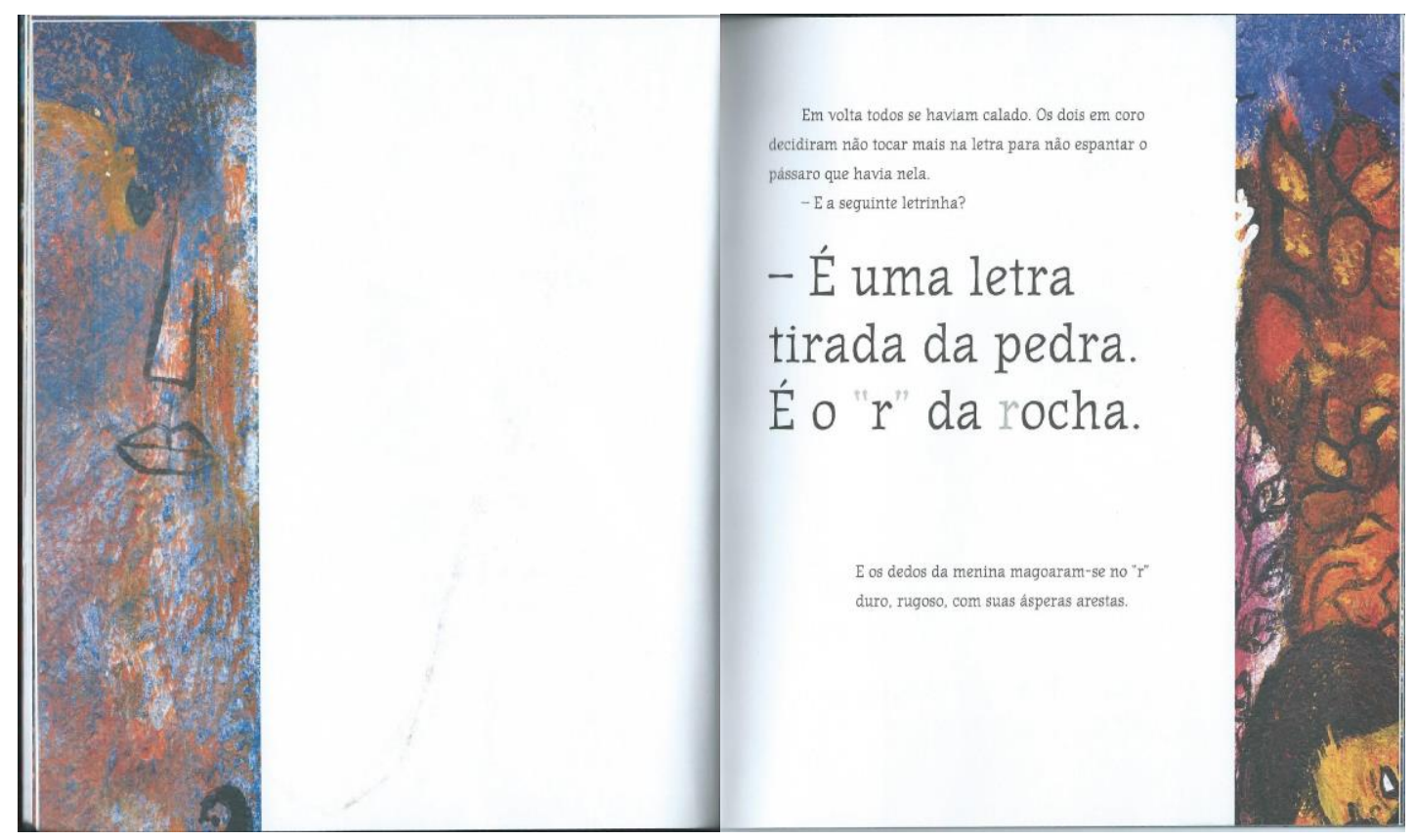

Figura 4.27. Ilustração de Malangatana para a obra O Beijo da Palavrinha, de Mia Couto. 
Em volta todos se haviam calado. Os dois, em coro, decidiram não tocar mais na letra para não espantar o pássaro que havia nela. E Zeca Zonzo pergunta:

- E a seguinte letrinha?

E os dedos da menina magoaram-se no "r" duro, rugoso, com suas ásperas arestas.

As letras ganham vida, significam e adquirem a materialidade do que representam. O "a" já não é mais só a letra "a"; é a gaivota e para que ela não voe, eles param de tocar no "a". O "r" se transforma em rocha com todas as qualidades inerentes a uma rocha, dura, rugosa a ponto de machucar os dedos da menina. Dedos que ganham vida e sentem a aspereza da letra escrita no papel a ponto de "magoarem-se". O autor explora com muita originalidade a própria materialidade da linguagem e abusa de seus efeitos verbais, visuais e sonoros. O ilustrador adere ao convite e abusa das representações possíveis em cada uma das imagens que apresenta para o leitor.

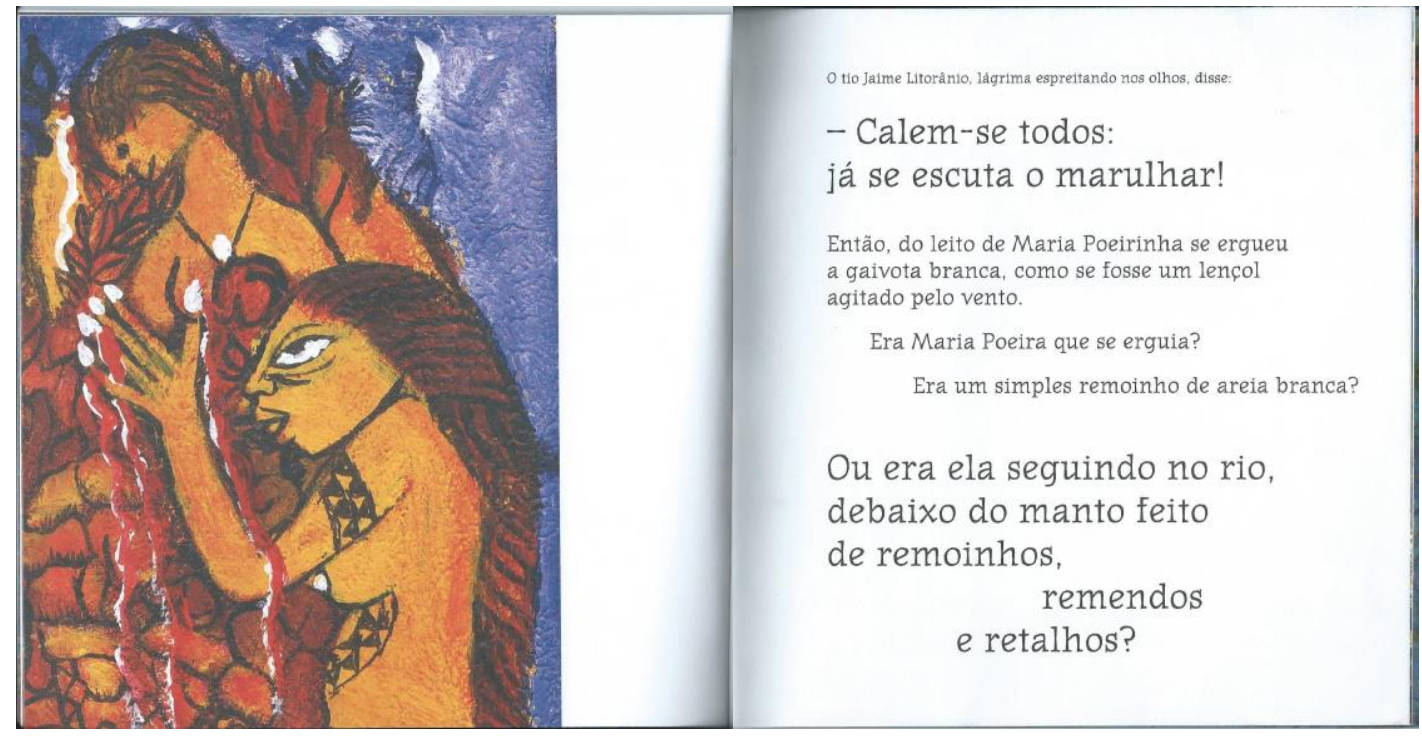

Figura 4.28. Ilustração de Malangatana para a obra O Beijo da Palavrinha, de Mia Couto. 
É possível ouvir o marulhar do mar, todos ouvem. E, assim, a gaivota branca se ergue do leito de Poerinha "como se fosse um lençol agitado pelo vento" e Maria Poerinha morre poeticamente.

E a moral da estória é ainda mais surpreendente, já que:

Ainda hoje, tantos anos passados, Zeca Zonzo, apontando o rosto da sua irmãzinha na fotografia, clama e reclama:

- Eis minha mana Poerinha que foi beijada pelo mar.

E se afogou numa palavrinha.

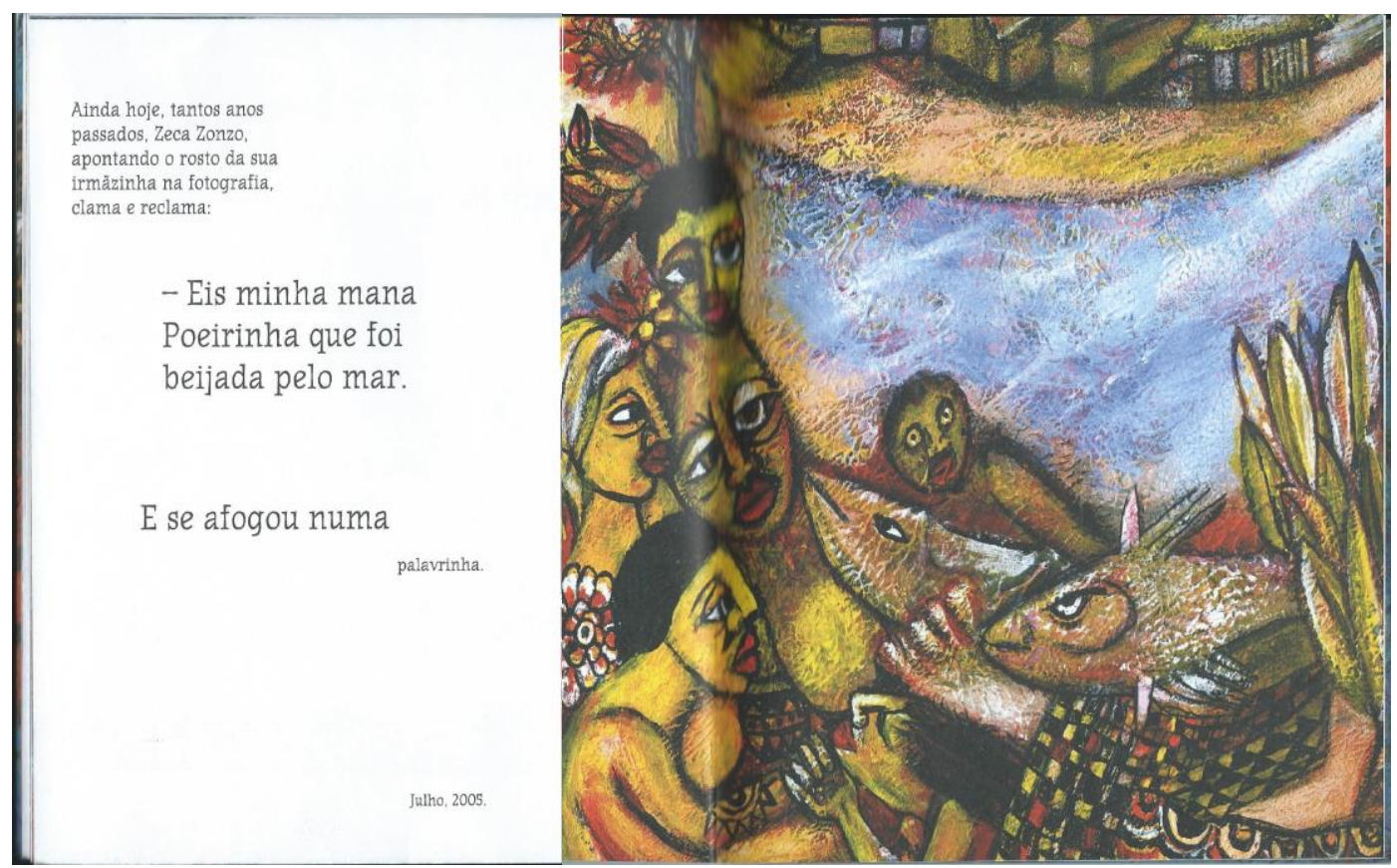

Figura 4.29. Ilustração de Malangatana para a obra O Beijo da Palavrinha, de Mia Couto.

Poeirinha foi beijada pelo mar e sua morte se deu por afogamento em uma palavrinha!

De acordo com Maria José Palo e Maria Rosa D. Oliveira: 
O pensamento infantil é aquele que está sintonizado com esse pulsar pelas vias do imaginário. E é justamente nisso que os projetos mais arrojados de literatura infantil investem, não escamoteando o literário, nem o facilitando, mas enfrentando sua qualidade artística e oferecendo os melhores produtos ao repertório infantil, que tem a competência necessária para traduzi-lo pelo desempenho de uma leitura múltipla e diversificada (PALO, 2006:11).

E é exatamente este pulsar pelas vias do imaginário que queremos devolver aos jovens que farão parte de nossa pesquisa. Jovens que terão que enfrentar a qualidade artística de um texto como $O$ Beijo da Palavrinha e que terão que ter a competência necessária para traduzi-lo. Se a tradução não for perfeita, esperamos que seja significativa o bastante para transformá-los. Além disso, o texto faz a ligação entre o corpo etérico (representado pela aldeia, pelo mar, pela natureza pobre do local em que vive Poerinha, pelos conhecimentos etnológicos do povo que vive neste local) e o corpo físico (representado pelos personagens da estória), conforme proposto por Steiner.

\subsubsection{A Moça Tecelã}

A obra A Moça Tecelã de Marina Colasanti ${ }^{97}$ foi publicada em 2004. Faremos um resumo da estória, devido ao fato do texto verbal aparecer na forma gráfica

\footnotetext{
${ }^{97}$ Marina Colasanti nasceu em 1937 em Asmara (Eritréia), na Etiópia. Viveu sua infância na África (Eritréia, Líbia). Depois seguiu para a Itália, onde viveu onze anos antes de vir para o Rio de Janeiro, onde reside desde de então. Possui nacionalidade brasileira e naturalidade italiana. Estudou pintura, foi colaboradora de vários periódicos, apresentadora de televisão e roteirista. Ingressou no Jornal do Brasil em 1962, como redatora do Caderno B, desenvolvendo atividades de cronista, colunista, ilustradora e subeditora e editora do Caderno Infantil. Em 1976, ingressou na Editora Abril, na revista Nova da qual já era colaborada, com a função de editora de comportamento. Escritora e jornalista, publicou mais de 30 obras, livros de contos, crônicas, poemas e histórias infantil. Em 1994, ganhou o Prêmio Jabuti de Poesia, por "Rota de Colisão" (1993) e o Prêmio Jabuti Infantil ou Juvenil, por “Ana Z Aonde Vai Você?”.
} 
comum a todos os textos escritos, sem alterações nos tamanhos das letras ou disposições em destaque. Fato este que não diminui em nada a poeticidade e magia do texto. Apresentaremos as ilustrações que compõem o livro, visto que são elas, em concomitância com o texto verbal, que imprimem sonoridade ao conto. Além disso, as ilustrações foram feitas com bordados de Ângela, Antônia Zulma, Marilu, Martha e Sávia Dumond ${ }^{98}$ sobre os desenhos de Demóstenes Vargas o que confere uma beleza e riqueza de formas, textura, cores e tons que, em comunhão com o texto verbal, transformam o livro em uma obra de Arte.

A ilustração da capa nos mostra a Moça sentada em seu tear, antecipando, dando pistas, sobre a estória que será contada.

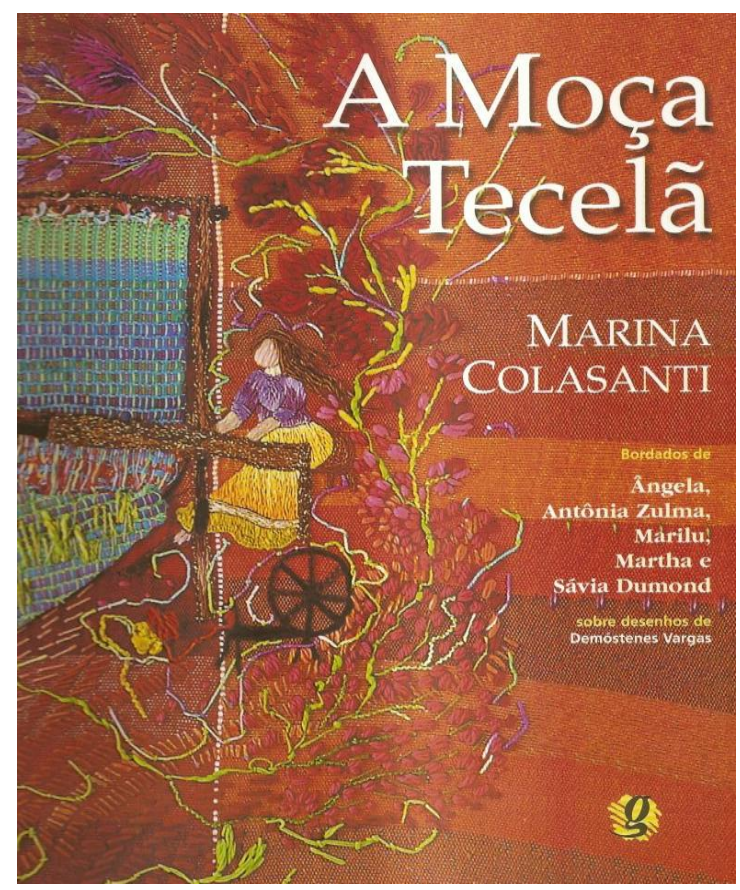

Figura 4.30. Ilustração da capa da obra A Moça Tecelã, de Marina Colasanti.

98 O grupo Matizes Dumond é formado por seis artistas da mesma família de Pirapora, Minas Gerais, e é composto pela mãe Antônia Zulma Diniz Dumond e cinco filhos: Ângela, Marilu, Martha, Sávia e Demóstenes. Nascidas em uma comunidade ribeirinha, as filhas aprenderam com a mãe a arte de bordar. A partir das peças utilitárias bordadas em tecidos de cambrai, linho, prometi, seda, organza ou algodão, descobriram seu próprio movimento de criar outros bordados transformados em tela que ilustram histórias de grandes autores brasileiros, como Jorge Amado, Ziraldo, Manoel de Barros, Thiago de Mello, Rubem Alves, Carlos Brandão, Tetê Catalão, Marina Colasanti e os próprios livros de Ângela e Sávia. 
A Moça Tecelã conta a estória de uma jovem que acordava todos os dias muito cedo e logo se sentava ao tear. Ela vivia só e tecia incansavelmente, variando as cores das lãs e interferindo nas cores do dia e da noite.

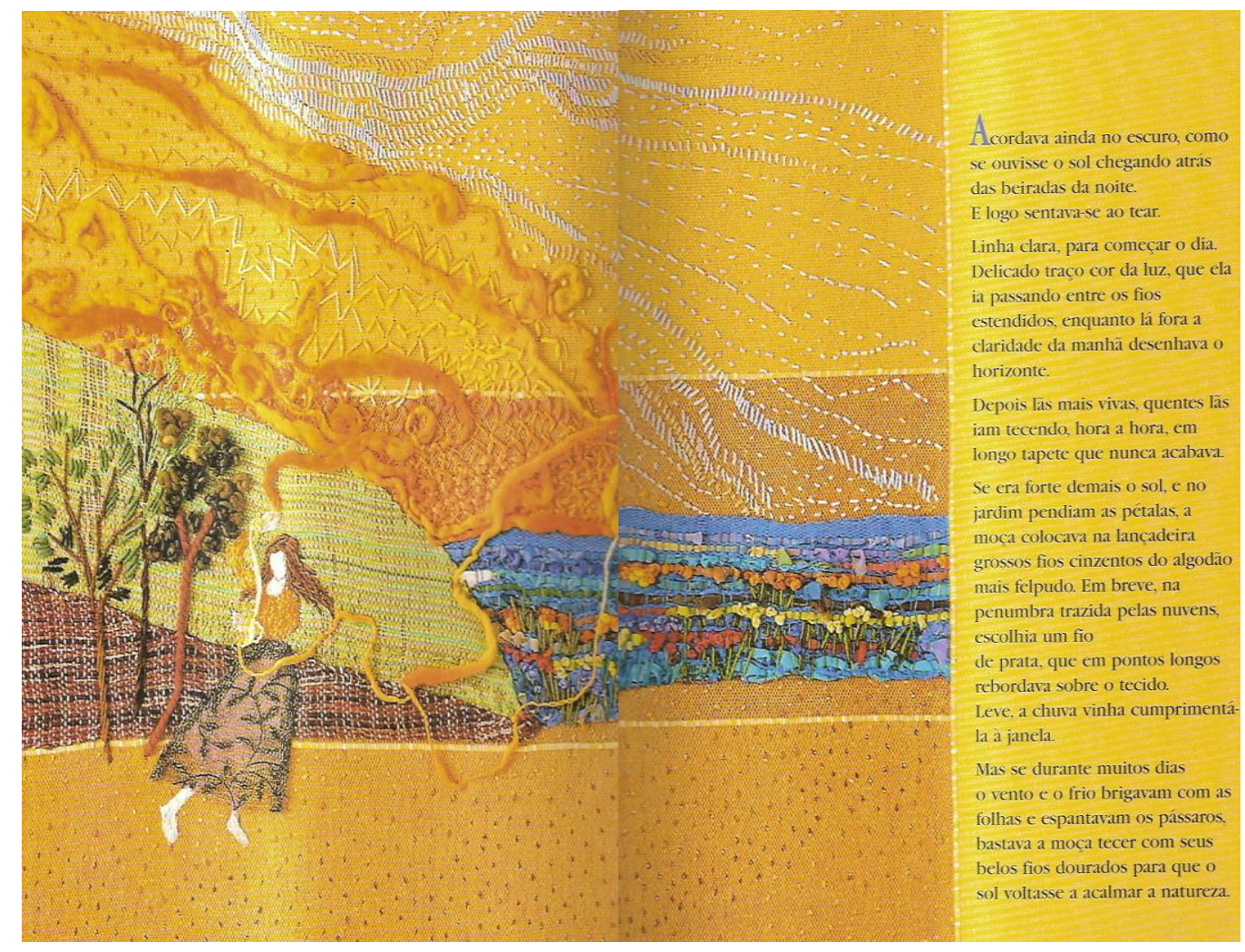

Figura 4.31. Ilustração para a obra A Moça Tecelã, de Marina Colasanti.

Partindo de uma realidade concreta, material e conhecida por nós, a autora nos transporta para o mundo mágico, no qual a tecelã influía por meio do seu tear, na natureza, como podemos comprovar no seguinte trecho da estória:

Se era forte demais o sol, e no jardim pendiam as pétalas, a moça colocava na lançadeira grossos fios cinzentos do algodão mais felpudo. Em breve na penumbra trazida pelas nuvens, escolhia um 
fio de prata, que em pontos longos rebordava sobre o tecido. Leve, a chuva vinha cumprimenta-la à janela.

Mas se durante muitos dias o vento e o frio brigavam com as folhas e espantavam os pássaros, bastava a moça tecer com seus belos fios dourados para que o sol voltasse a acalmar a natureza.

Quando tinha fome, tecia o alimento que iria alimentá-la, "tecia um lindo peixe, com cuidado de escamas. E eis que o peixe estava na mesa pronto para ser comido". Tudo que ela necessitava era feito em seu tear.

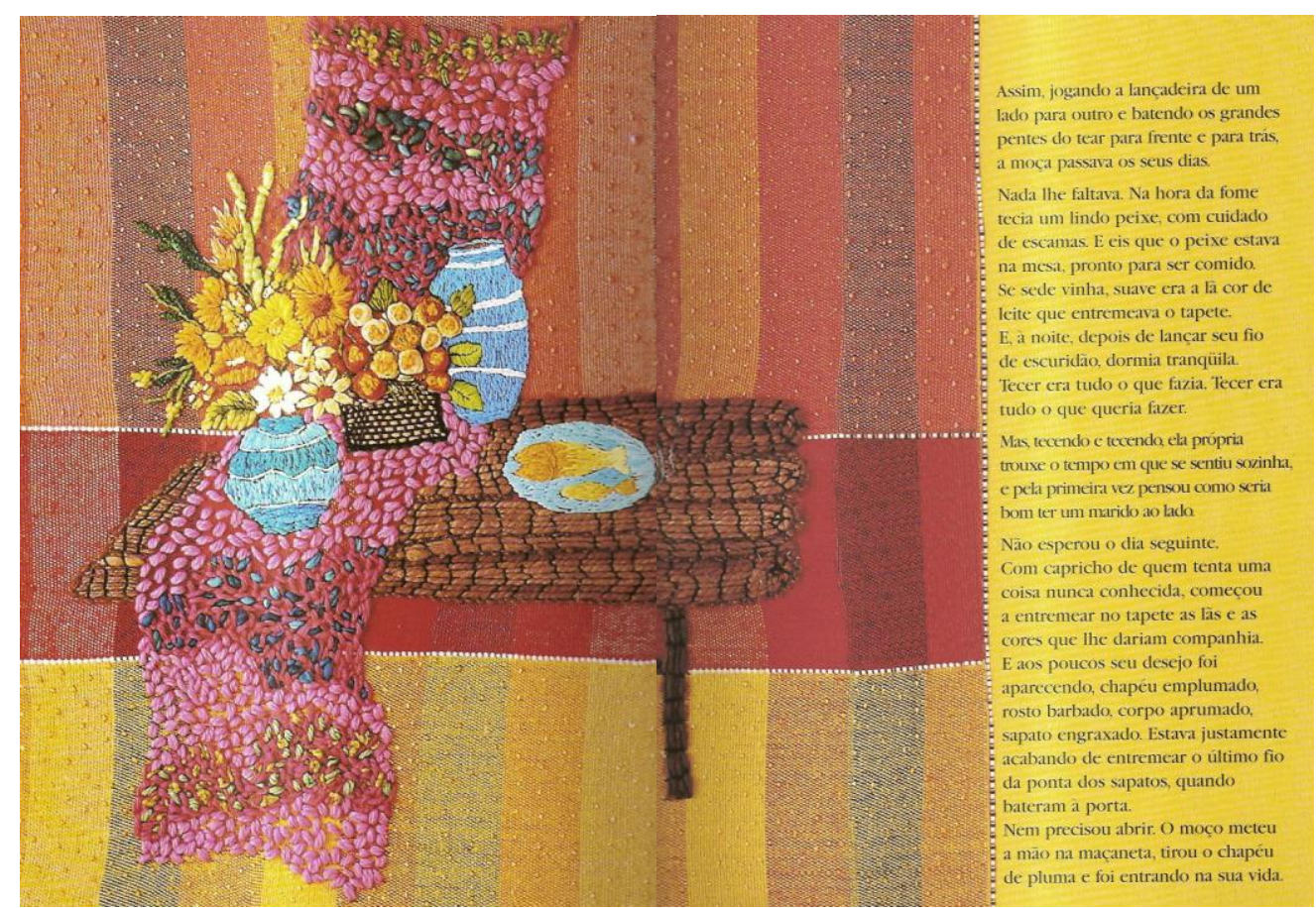

Figura 4.32. Ilustração para a obra A Moça Tecelã, de Marina Colasanti.

A narrativa traz características mitológicas ao atribuir à moça a mesma força dos Deuses da mitologia que tinham o poder de influenciar e transformar a natureza. Ao mesmo tempo, traz caraterísticas dos contos de fada, principalmente no que diz respeito à introdução na estória de uma situação problemática que deverá ser 
superada pela personagem principal:

Mas, tecendo e tecendo, ela própria trouxe o tempo em que se sentiu sozinha, e pela primeira vez pensou como seria bom ter um marido a seu lado.

Não esperou o dia seguinte. Com o capricho de quem tenta uma coisa nunca conhecida, começou a entremear no tapete as lãs e as cores que the dariam companhia. $E$ aos poucos seu desejo foi aparecendo, chapéu emplumado, rosto barbado, corpo aprumado, sapato engraxado. Estava justamente acabando de entremear o último fio da ponta dos sapatos, quando bateram à porta.

Nem precisou abrir. $\mathrm{O}$ moço meteu a mão na maçaneta, tirou $\mathrm{O}$ chapéu de pluma e foi entrando em sua vida.

A entrada do moço em sua vida marca um momento de mudança, uma ruptura que irá marcar uma transformação. A moça tecelã se assemelha às princesas dos contos de fada, princesa prendada que sabe fiar e combinar cor e tons. Como toda princesa, ela tem direito ao seu príncipe encantado, que na estória é tecido como um tapete e adquire vida própria.

Deitada ao lado do seu príncipe, com a cabeça em seu ombro, a moça passa a pensar "nos filhos que teria com ele para aumentar ainda mais a sua felicidade". Felicidade que não durou muito tempo, já que o príncipe se transformou em homem e se tornou cada vez mais ganancioso pensando nas coisas que ela poderia criar com seu tear.

Então, ele quis a casa e, depois da casa, o palácio (ou castelo dos contos de fada) com estrebarias e cavalos, tesouros, criados etc.

Foi assim que a moça deixou de tecer o dia e a noite, por falta de tempo, já que estava muito ocupada em tecer tudo o que seu marido queria: 
Dias e dias, semanas e meses trabalhou a moça tecendo tetos e portas, e pátios e escadas, e salas e poços. A neve caía lá fora, e ela não tinha tempo para chamar o sol. A noite chegava, e ela não tinha tempo para arrematar o dia. Tecia e entristecia, enquanto sem parar batiam os pentes acompanhando o ritmo das lançadeiras.

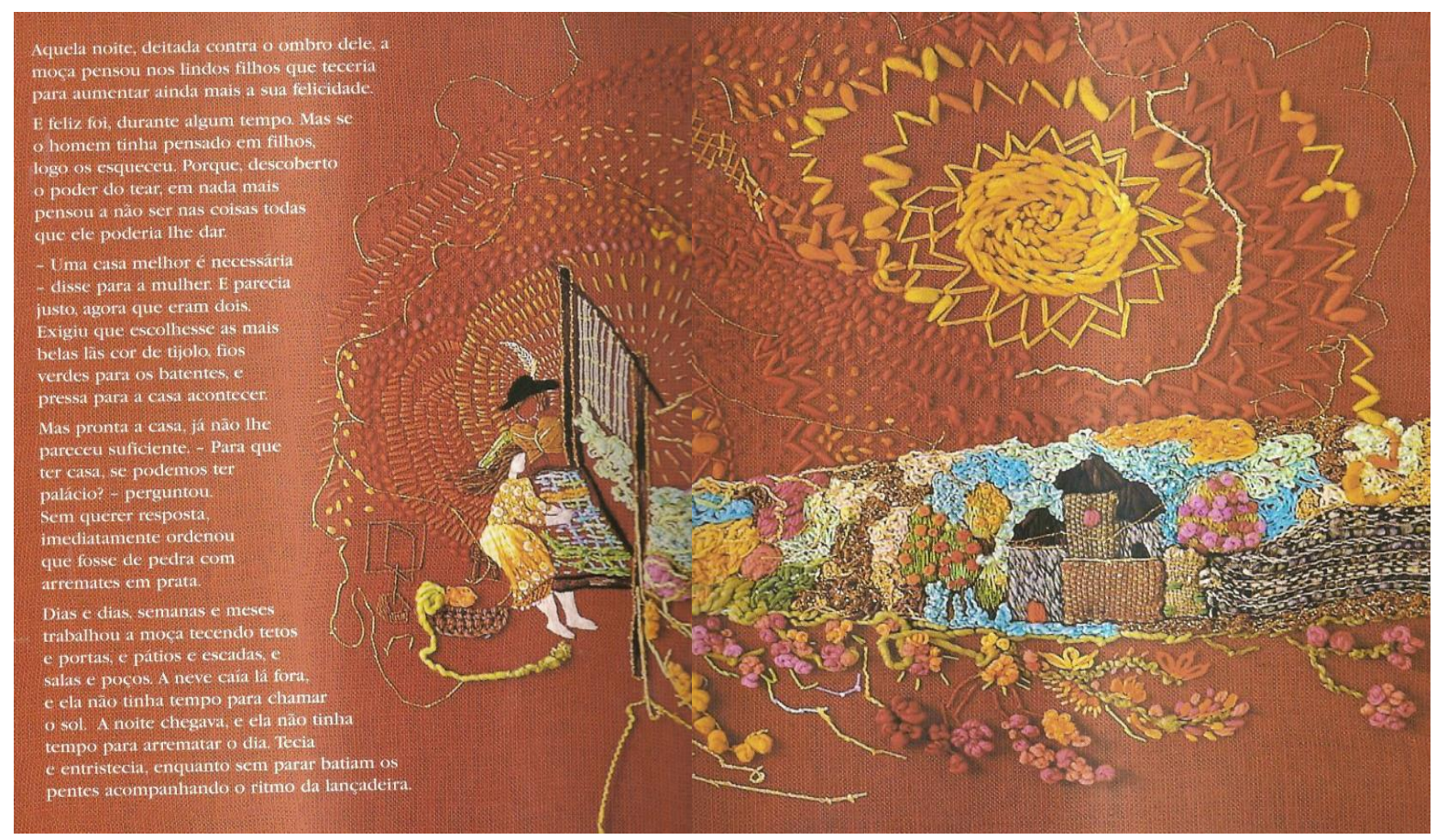

Figura 4.33. Ilustração para a obra A Moça Tecelã, de Marina Colasanti.

$\mathrm{E}$, quanto mais ela tecia, mais ele queria. Até que ele teve a ideia de escolher um dos cômodos do castelo, o mais alto, para que ela pudesse ficar escondida tecendo, sem que ninguém soubesse do tapete. E lá ele trancou a moça.

Neste ponto da história, o marido, tecido inicialmente à semelhança dos príncipes encantados, poderia ser facilmente confundido com a feiticeira do conto de fada Rapunzel - da coleção dos irmãos Grimm - que aprisionou Rapunzel, aos doze anos, em uma torre que não tinha escada nem porta. 


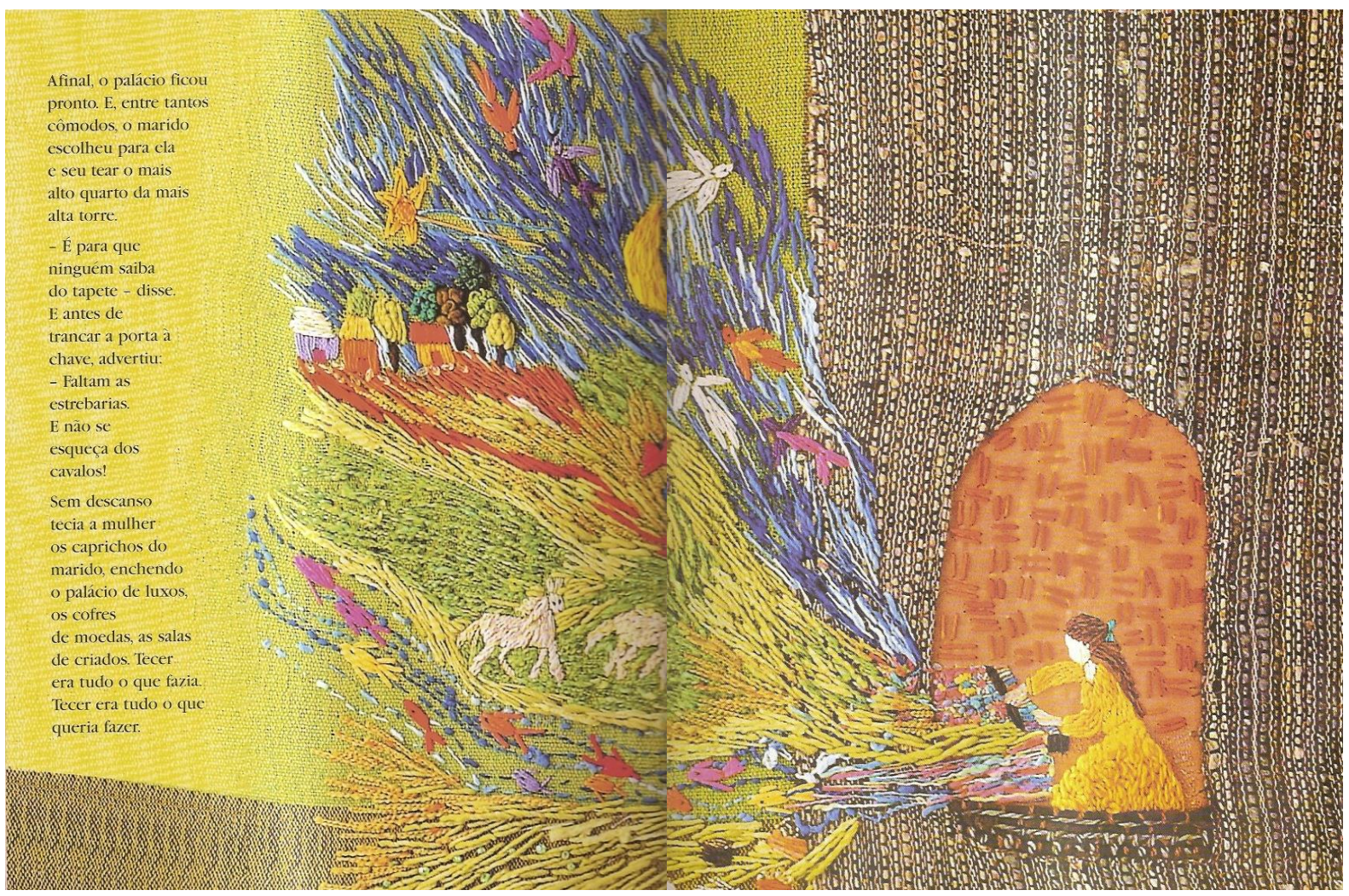

Figura 4.34. Ilustração para a obra A Moça Tecelã, de Marina Colasanti.

Trancada em sua torre pelo príncipe, a moça foi ficando cada vez mais triste: "E tecendo, ela própria trouxe o tempo em que sua tristeza lhe pareceu maior que o palácio com todos os seus tesouros. E, pela primeira vez, pensou em como seria bom estar sozinha de novo". E foi assim que:

Só esperou anoitecer. Levantou-se, enquanto o marido dormia, sonhando com novas exigências. $E$ descalça, para não fazer barulho, subiu a longa escada da torre, sentou-se em seu tear.

Desta vez não precisou escolher linha nenhuma. Segurou a lançadeira ao contrário e, jogando-a veloz de um lado para o outro, começou a desfazer seu tecido. 


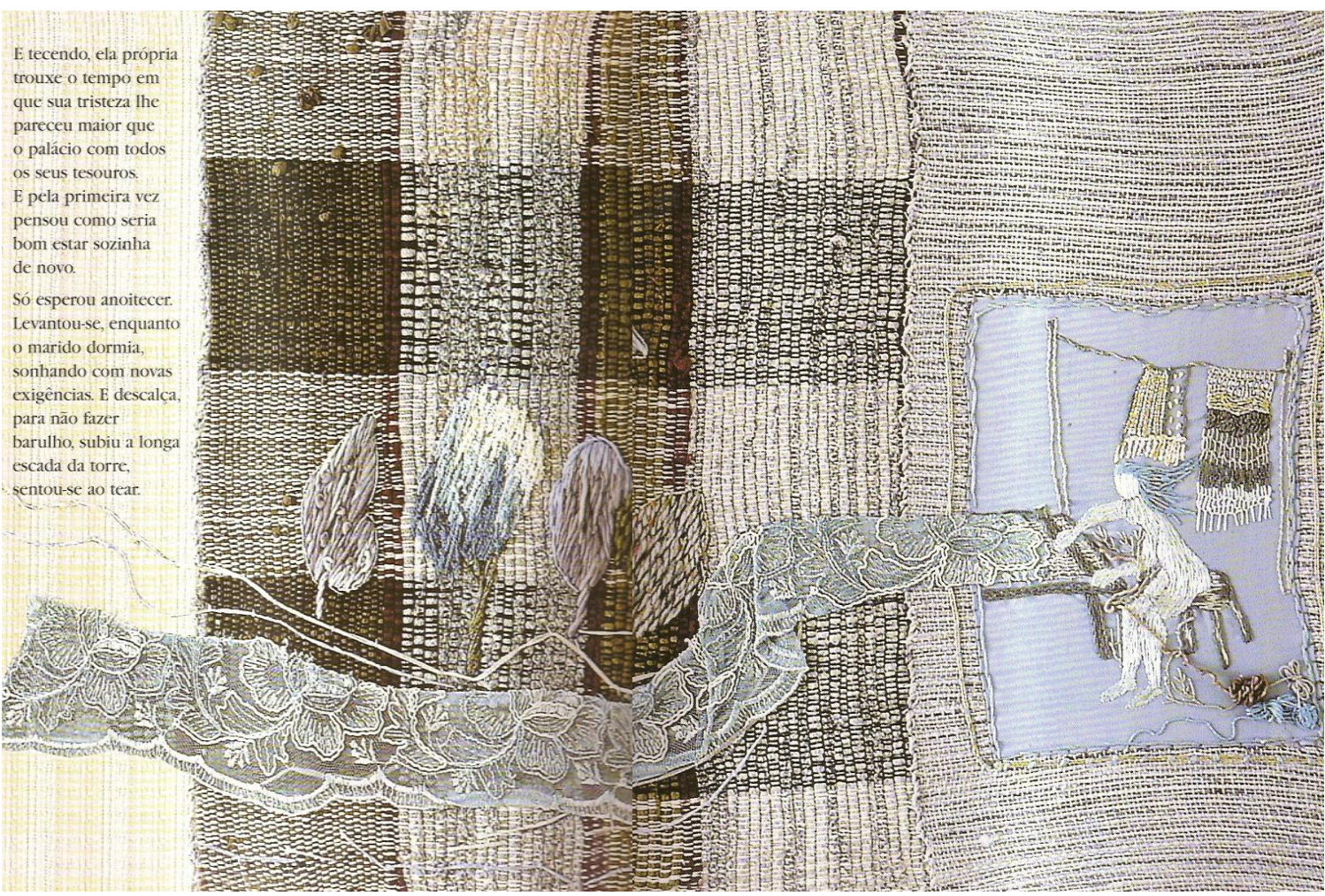

Figura 4.35. Ilustração para a obra A Moça Tecelã, de Marina Colasanti.

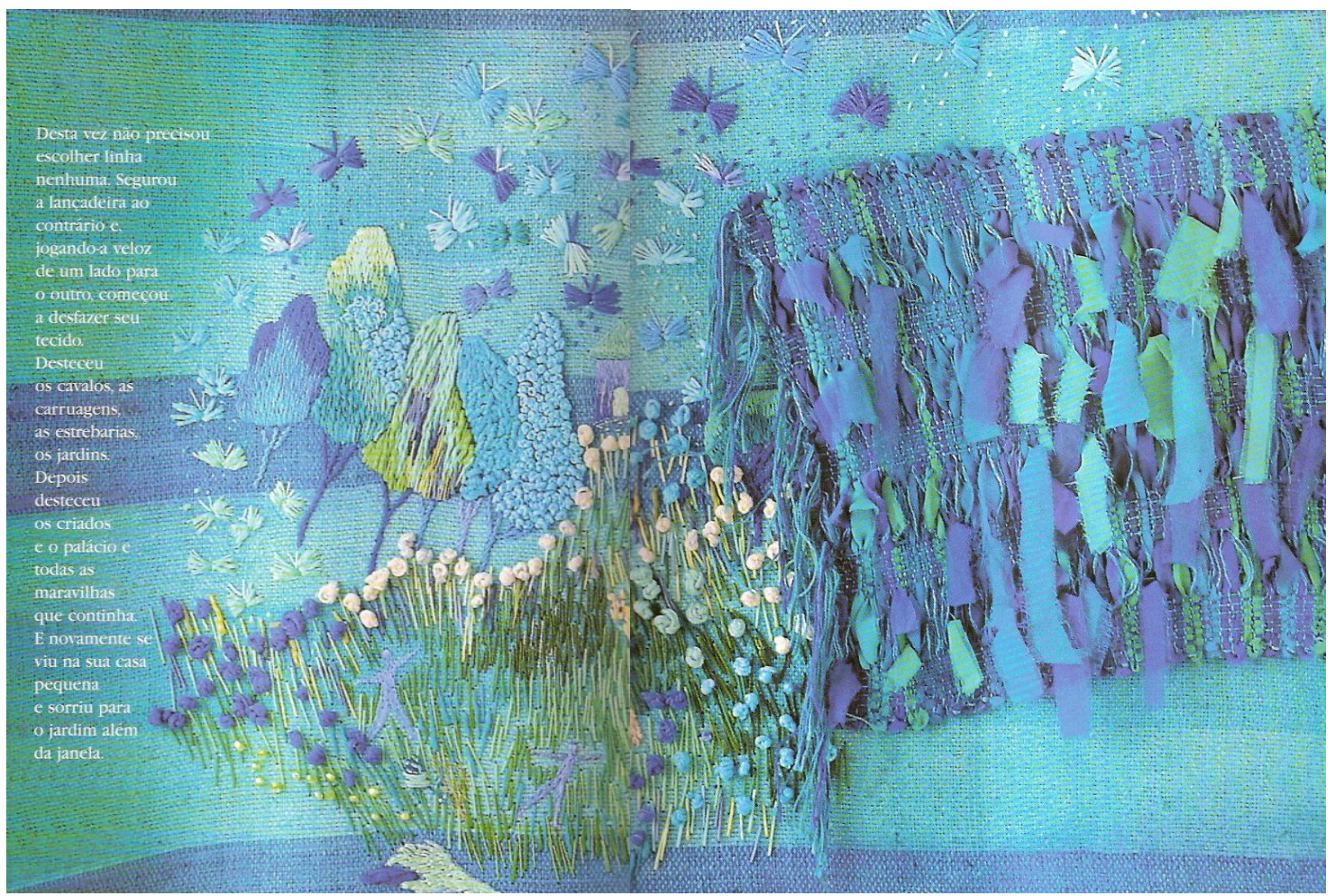

Figura 4.36. Ilustração para a obra A Moça Tecelã, de Marina Colasanti. 
O marido despertou e nem teve tempo de entender o que estava acontecendo:

A noite acabava quando o marido, estranhando a cama dura, acordou e, espantado, olhou em volta. Não teve tempo de se levantar. Ela já desfazia o desenho escuro dos sapatos, e ele viu seus pés desaparecendo, sumindo as pernas. Rápido, o nada subiuIhe pelo corpo, tomou o peito aprumado, o emplumado chapéu.

Então, como se ouvisse a chegada do sol, a moça escolheu uma linha clara. E foi passando-a devagar entre os fios, delicado traço de luz, que a manhã repetiu na linha do horizonte.

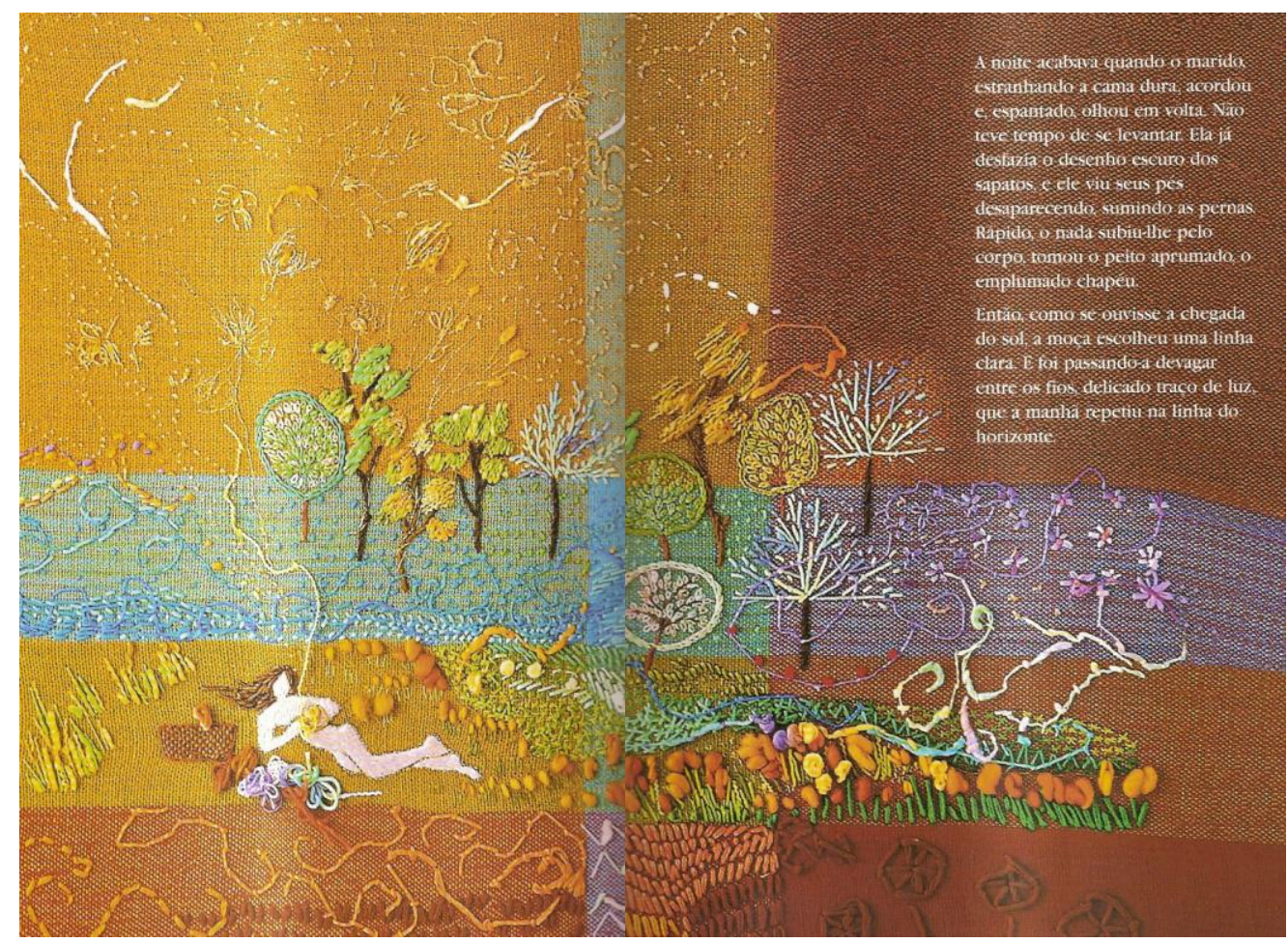

Figura 4.37. Ilustração para a obra A Moça Tecelã, de Marina Colasanti.

E, foi assim, que a moça desteceu seu marido (príncipe) que foi desfeito (destruído) pela moça. Ela preferiu ficar sozinha a ter alguém que queria tudo. 
Considerando que nenhum texto nasce isolado, a estrutura narrativa do texto A Moça Tecelã é a materialização de um discurso que propõe novos paradigmas, questionando os tradicionais, visto que modifica os valores morais e comportamento da figura tradicional da princesa desprotegida, submissa, indefesa que é caracterizada nos contos de fadas. A Moça Tecelã quebra esse paradigma da princesa, enquadrando-a em um contexto social em que a mulher participa e é capaz de tomar decisões na construção de sua história e de seu destino. Ao mesmo tempo em que traz a ganância da época em que vivemos, em que ter é mais importante do que ser. A obra remete ao mito da criação por meio do símbolo do tear que, de acordo com Jean Chevalier e Alain Gheerbrant, simboliza a estrutura e o movimento do universo. Eles explicam que:

(...) O trabalho de tecelagem é um trabalho de criação, um parto. Quando o tecido está pronto, o tecelão corta os fios que o prendem ao tear e, ao fazê-lo, pronuncia a fórmula de benção que diz a parteira ao cortar o cordão umbilical do recém-nascido. (...) Tecido, fio, tear, instrumentos que servem para tear ou tecer (fuso, roca) são todos eles símbolos do destino. Servem para designar tudo o que rege ou intervém no nosso destino: a lua tece os destinos; a aranha tecendo sua teia é a imagem das forças que tecem nossos destinos. As Moiras são fiandeiras, atam o destino, são divindades lunares. Tecer é criar novas formas.

Tecer não significa somente predestinar (com relação ao plano antropológico) e reunir realidades diversas (com relação ao plano cosmológico), mas também criar, fazer sair de sua própria substância, exatamente como faz a aranha, que tira de si própria a sua teia (ELIT, 159). (...) Fiandeiras e tecelãs abrem e fecham indefinidamente os ciclos individuais, históricos e cósmicos (CHEVALIER, 2012:872-873) ${ }^{99}$.

${ }^{99}$ [grifos do autor]. 
Há uma relação entre os mitos e os contos de fadas e é difícil separá-los ou determinar as origens e influências de um sobre o outro. Utilizando-se da linguagem de símbolos, ambos apresentam personagens exemplares e acontecimentos fantasiosos, porém a forma de comunicá-los é bastante distinta. Nos contos de fadas as situações inusitadas e improváveis são narradas com naturalidade de forma casual e cotidiana como se pudessem acontecer a qualquer um de nós. Já nos mitos, os feitos e acontecimentos são grandiosos, miraculosos e admiráveis e não poderiam acontecer a um simples mortal. Além disso, nos contos de fadas há sempre um final feliz enquanto que nos mitos o final da história é, normalmente, trágico.

Marina Colasanti combinou as duas coisas e nos oferece uma estória rica em simbologia e possibilidades, capaz de dialogar com nossos sentimentos, aguçar nossa percepção. O texto constrói e materializa um mundo imaginário no qual é possível tecer, entre outras coisas, um marido. Há, nesse sentido, uma ruptura com a realidade e essa ruptura se repete no momento em o marido é destruído, que marca a desconstrução de uma realidade pré-construída no texto. A ruptura é marcada pelo imaginário no sentido de podermos construir e desconstruir (ou tecer e destecer maridos).

A autora conferiu ao texto verbal o ritmo sonoro do tear, tecemos com ela e nos divertimos com a possibilidade de poder (des)tecer seja lá o que estiver nos incomodando.

Consideramos que a obra será de grande valia para os jovens que farão parte de nossa pesquisa, que poderão repensar nos papeis de homem e mulher que pretendem assumir em suas vidas. A estória possibilita a simbolização do corpo 
físico e a integração deste corpo com os quatro corpos constitutivos propostos por Steiner.

\subsection{MÉTODO UTILIZADO NA EXPERIÊNCIA ESTÉTICA DE RECEPÇÃO DA LEITURA}

Optamos por trabalhar os grupos separadamente. Para cada grupo propôs-se duas datas e horários distintos para que eles escolhessem, de acordo com suas necessidades, a melhor dada para realizar a experiência estética de recepção de leitura. Os encontros com os alunos formados pela Pedagogia Waldorf foram realizados em uma sala de aula da própria escola em que eles estudaram até o final do Ensino Médio, momento que proporcionou um reencontro desses alunos em um local que, com certeza, trouxe lembranças. Os encontros com os alunos formados por outras pedagogias foram realizados em uma sala de aula da universidade onde eles estudam em São Paulo, território conhecido e frequentado por eles.

No primeiro encontro com cada grupo, houve uma fala introdutória explicitando a proposta da pesquisa, que não prevê nenhuma interpretação das obras que serão lidas, visto que o interesse está na sensação proporcionada por cada leitura em cada um dos participantes em particular. Em seguida, os alunos receberam um questionário de avaliação das leituras propostas. As leituras foram realizadas em etapas sucessivas iniciando com a apresentação das obras.

No primeiro momento mostramos aos alunos o primeiro volume da coletânea com quinze volumes "O Mundo da Criança" que contém poemas da primeira infância dos quais foram selecionados dois para a leitura. A leitura dos dois poemas foi feita em duas etapas. 
$\mathrm{Na}$ primeira etapa, os alunos receberam, cada um, uma cópia do poema "Pobre Vovô!" que foi lido em voz alta pelo entrevistador e os participantes puderam acompanhar a leitura oral por meio da leitura visual do poema. Após a leitura, foi dado um tempo aos participantes para responderem às duas primeiras perguntas do questionário: "Você gostou do poema?" e "Você gostou da ilustração?" sendo dadas quatro opções de respostas para cada uma das questões propostas: "sim", "não", "mais ou menos" e "gostei muito". Logo abaixo das opções aparecia a opção: "Quer comentar sua resposta?', caso algum aluno quisesse dar seu parecer.

Ao término desta etapa, distribuímos aos participantes uma cópia do segundo poema: "Vocês Acreditam?". Durante a distribuição observou-se as reações dos alunos, se houve interação entre eles, troca de informações sobre o primeiro poema, quais comentários foram tecidos por eles e como estava o clima pós-leitura. Mais uma vez o poema foi lido em voz alta pelo entrevistador e os alunos acompanharam a leitura de forma visual. Em seguida, eles tiveram um tempo para responder a terceira e a quarta perguntas do questionário que eram idênticas às duas primeiras, porém em relação ao segundo poema. Estas duas etapas foram rápidas, visto que os poemas são curtos.

Ao término da leitura dos dois primeiros poemas, cada aluno recebeu um exemplar do livro "Vi uma Estrela lá fora". Foram comprados trinta livros para que cada aluno pudesse realizar a leitura individualmente e no seu ritmo. Após a leitura, os alunos responderam a quinta e a sexta questões, alteradas para: "Você gostou da estória?" e "Você gostou das ilustrações?", sendo dadas as mesmas opções de respostas: "sim", "não", "mais ou menos" e "gostei muito". Manteve-se a opção: "Quer comentar sua resposta?". 
Em seguida, apresentamos um exemplar do segundo volume da coletânea de oito volumes dos Irmãos Grimm e distribuímos uma cópia para cada um da estória “A Raposa e o Cavalo". Os alunos tiveram tempo para a leitura individual e para responder a sétima pergunta do questionário: "Você gostou da estória?" com quatro opções de respostas: "sim", "não", "mais ou menos" e "gostei muito". Também foi dado espaço caso eles quisessem comentar a resposta.

Na sequência, foi feita a apresentação do livro "Contos e Fábulas do Brasil" e a distribuição de uma cópia da estória "O Príncipe Cavalinho" para cada um dos participantes. A estória foi lida em voz alta pelo entrevistador e os alunos acompanharam a leitura oral por meio da leitura visual do conto. Após a leitura, foi dado um tempo aos participantes para responderem a oitava pergunta do questionário: "Você gostou da estória?" com quatro opções de respostas: "sim", "não", "mais ou menos" e "gostei muito", abrindo espaço para os alunos que quisessem comentar sua resposta.

Terminada esta etapa, o entrevistador distribuiu aos participantes um exemplar do livro "O Beijo da Palavrinha". Foi dado um tempo para a leitura individual do livro, respeitando o ritmo de cada participante, e um tempo para que fossem respondidas a nona e a décima perguntas do questionário: "Você gostou do livro?" e "Você gostou das ilustrações?', com as mesmas opções de respostas: "sim", "não", "mais ou menos" e "gostei muito". E com espaço para que eles comentassem suas respostas.

Em seguida, foi distribuído, para cada participante, um exemplar do livro " $A$ Moça Tecelâ". Foi realizada a leitura oral da estória pelo entrevistador enquanto os participantes acompanhavam por meio da leitura visual. $\mathrm{Na}$ sequência, os 
participantes responderam a décima primeira e a décima segunda perguntas do questionário, idênticas à nona e à décima questões com espaço para comentários.

Ao término desta etapa, o entrevistador orientou os alunos a responderem às perguntas 13, 14, 15, 16 e 17 do questionário, que serão apresentadas após algumas explicações. O padrão de resposta dessas questões será sempre o mesmo, isto é, o aluno deverá marcar a obra que representa a resposta que ele quer dar, podendo não marcar nenhuma, uma, mais de uma, ou ainda, todas. Para isso, ele terá os nomes das obras com espaço para marcar um "x" se quiser (exemplificando, o aluno visualizará as seguintes opções: "O poema Pobre Vovô! ( )", "O poema Vocês Acreditam? ( )", "O conto Vi uma Estrela lá fora ( )", "O conto A Raposa e o Cavalo ( )", "O conto O Príncipe Cavalinho ( )", "O conto O Beijo da Palavrinha ( )" e "O conto A Moça Tecelã ( )"). As perguntas são: 13) "Assinale a(s) estória(s) que fizeram você se sentir parte integrante da estória:"; 14) "Assinale a(s) estória(s) que você preferia não ter lido:"; 15) "Assinale a(s) estória(s) que você gostaria de ter em sua biblioteca particular:"; 16) "Assinale a(s) estória(s) que você indicaria como leitura indispensável às pessoas que você ama." e 17) "Assinale a(s) estória(s) que fizeram você repensar nas frases que você utilizou para definir a velhice, a morte e a vida, no primeiro questionário respondido antes da leitura das obras”.

A última pergunta do questionário é aberta e pede ao aluno que dê sua opinião do que representou para ele participar desta pesquisa.

É importante salientar que a observação das reações dos alunos foi constante nos dois encontros e em cada etapa proposta. As impressões observadas serão reportadas no próximo capítulo, juntamente com a apresentação dos resultados das duas etapas da pesquisa. 


\section{5}

\section{APRESENTAÇÃO DOS RESULTADOS DA PESQUISA}

Este capítulo apresenta os resultados das duas etapas propostas para a pesquisa de campo. Inicia apresentando os ambientes em que a experiência estética de recepção de leitura foi realizada. Na sequência, apresenta os resultados das respostas dadas ao questionário um, que buscava averiguar as semelhanças e diferenças com relação aos interesses e hábitos de leitura literária e posicionamento em relação às questões essenciais da vida, tais como a velhice e a morte, entre exalunos formados pela pedagogia Waldorf e ex-alunos formados por outras pedagogias. Em seguida, apresenta os resultados das respostas dadas ao questionário utilizado na experiência estética de recepção da leitura. Finaliza com reflexões e considerações sobre os resultados obtidos nas duas etapas propostas para a pesquisa de campo.

\subsection{APRESENTAÇÃO DOS AMBIENTES EM QUE A PESQUISA FOI REALIZADA}

Há duas grandes escolas que adotam a Pedagogia Waldorf na cidade de São Paulo: Escola Waldorf Rudolf Steiner e Colégio Waldorf Micael de São Paulo. Ambas as escolas foram contatadas e receberam a proposta da pesquisa. Uma das escolas aceitou ceder o espaço para o encontro com os ex-alunos, porém, recusou-se a enviar a proposta via ex-professores tutores e negou-se a oferecer qualquer contato desses ex-alunos. Fato que dificultou e atrasou o início da pesquisa de campo. A 
segunda escola aceitou divulgar a pesquisa aos ex-alunos, porém solicitou que o encontro fosse feito em outro local.

Por intermédio de uma ex-aluna da primeira escola conseguimos contatar catorze ex-alunas. Foi necessário usar a rede social, Facebook, como ferramenta de contato, visto que a maioria desses alunos não tem o hábito de utilizar e-mail. No corpo a corpo, em uma das festas realizadas em junho pela primeira escola, conseguimos mais quatro candidatos, quatro rapazes que participavam da festa, chegando a dezoito possíveis entrevistados. Da outra escola, não houve adesão, embora alguns ex-alunos tenham recebido o questionário e demonstrado interesse em participar, não devolveram o questionário preenchido, ficando apenas na vontade, não havendo ação para a viabilização da pesquisa.

Dos dezoito candidatos da primeira escola, apenas catorze responderam ao primeiro questionário, destes, apenas nove compareceram ao encontro para a realização da segunda etapa da pesquisa, sendo que oito compareceram na primeira data proposta, dia 7 de junho, e apenas uma ex-aluna compareceu na segunda data proposta, dia 13 de junho.

Havíamos solicitado à escola uma sala com carteiras, visto que os alunos necessitariam de espaço para escrever e manusear os livros. Para a primeira data proposta, a escola cedeu uma das salas de inglês. A chave deveria ser retirada no próprio dia diretamente com a professora de Inglês às onze horas, porém, houve um desencontro. Os alunos também não apareceram no horário marcado, mas foram eles que conseguiram outra sala, em que não havia carteiras, só cadeiras, visto que era sala de euritmia ${ }^{100}$. A atividade teve início às treze horas, com duas horas de

${ }^{100}$ Lembrando que a eurritmia criada por Rudolf Steiner envolve movimentos e gestos que são executados de 
atraso em relação ao previsto. As quatro meninas optaram por sentar-se no chão e os quatro meninos sentaram-se nas cadeiras depositando os livros no chão e recolhendo-os conforme suas necessidades durante a pesquisa. $O$ pesquisador optou por sentar-se no chão com as moças. $O$ ambiente não era adequado, porém a pesquisa ocorreu sem problemas. Durante as leituras, houve pouca interação entre os alunos, sem nenhum comentário ou troca de informações referentes às leituras. Todos estavam tranquilos e atentos à leitura e responderam ao segundo questionário com comprometimento e disposição. As meninas ficaram na sala com o pesquisador, enquanto o último rapaz finalizava seu questionário. Elas disseram estar curiosas para ver o resultado e fizeram perguntas sobre a pesquisa e quando poderiam lê-la.

Para o segundo encontro, a escola explicou que não poderia ceder nenhuma sala de aula, visto que já estavam de férias, mas cedeu a sala de música e disponibilizou algumas cadeiras. Como apenas uma ex-aluna compareceu, ela sentou-se ao piano, baixou a tampa e realizou as atividades sobre ele. Mais uma vez, o ambiente não era adequado, mas a pesquisa transcorreu sem problemas. A ausência dos demais alunos, dos dez previstos apenas uma compareceu, comprovou a não adesão dos ex-alunos Waldorf à pesquisa.

As datas propostas para o encontro com os ex-alunos formados por outras pedagogias foram dia 9 e dia 11 de junho às 20 horas. Em ambas as datas as salas disponibilizadas para a pesquisa eram muito adequadas, com mesa para o pesquisador e várias carteiras disponíveis. Na primeira data, compareceram vinte e um alunos. Entre uma leitura e outra, os alunos comentavam as estórias e voltavam a silenciar assim que começava uma nova leitura. O ambiente estava alegre. ginástica, dança ou mímica, mas reproduz movimentos que são executados, na sua maioria, em pé. 
Durante a leitura do conto "O Príncipe Cavalinho", na hora da patada que matou a primeira filha do rei, o silêncio foi rompido por um coro de gargalhadas. O mesmo aconteceu quando a segunda filha foi morta pelo príncipe. Ao final da atividade, um aluno pediu para ficar com o livro "O Beijo da Palavrinha" e uma aluna pediu para ficar com todos os livros. Vários alunos cercaram o pesquisador e fizeram comentários positivos sobre as leituras, inclusive pediram mais atividades deste tipo.

Nove alunos compareceram ao segundo encontro com os ex-alunos formados por outras pedagogias. Quatro destes alunos não atendiam as delimitações da pesquisa, visto que haviam concluído o Ensino Médio há mais de dois anos; mesmo assim, insistiram em participar. Como a quantidade prevista de entrevistados superava a esperada em relação aos ex-alunos Waldorf, consentimos. Houve menos interação entre eles do que entre o grupo do dia 9 de junho, mas estavam serenos e tranquilos. Ao final, agradeceram e também pediram mais atividades deste tipo.

\subsection{APRESENTAÇÃO DOS RESULTADOS DAS RESPOSTAS AO QUESTIONÁRIO UM}

A primeira dificuldade encontrada para a análise do questionário um foi a disparidade na quantidade de alunos participantes em cada grupo, sendo catorze exalunos Waldorf e trinta e cinco alunos formados por outras pedagogias. Partimos da análise do grupo de ex-alunos Waldorf para a determinação do grupo a ser comparado com eles. Como o grupo Waldorf era composto por quatro rapazes (Caio, Daniel, Gabriel e Tobias) e dez moças (Bruna, Carol, Caroline, Clara, Isabela, Júlia 
1, Júlia 2, Marina, Sofia 1 e Sofia 2) dois deles nascidos em 1994 e os demais nascidos em 1995, selecionou-se catorze alunos do grupo formado por outras pedagogias com as mesmas características de sexo e idade. Desta forma, chegouse ao grupo formado por Amanda 1, Amanda 2, Bruna, Cibele, Danielle, Lilian, Lizandra, Nathalia 1, Raquel, Suellen, Gabriel, Guilherme, Igor e Matheus, sendo dois nascidos em 1994 e os demais nascidos em 1995.

Curiosamente, ao analisar os alunos restantes, formados por outras pedagogias, verificou-se que catorze deles nasceram em 1996, o que levou a uma segunda análise por meio da comparação com os mesmos catorze ex-alunos Waldorf com alunos nascidos posteriormente. Desta forma, participaram da segunda análise Daphine, Drieli, Elaine, Elizabete, Emanuelle, Larissa, Nathalia 2, Paloma, Sarah, Talita, Val, Marcos, Pedro, Sidney.

Verificou-se, em relação à primeira pergunta ("Você frequentou o jardim de infância?'), que apenas dois ex-alunos Waldorf não cursaram o Jardim de Infância (Gabriel e Júlia 1), no primeiro grupo de ex-alunos formados por outras pedagogias apenas três alunos não cursaram (Gabriel, Mateus e Raquel) e, do grupo de participantes nascidos em 1996, apenas uma aluna não frequentou o Jardim de Infância (Drielli). Fato que torna os grupos bastante homogêneos quanto ao contato com as artes em geral (desenho, pintura, modelagem etc.) e com o lúdico (ouvir estórias, cantigas, recitar versinhos, brincar, interagir com outras crianças) no período anterior à alfabetização.

Verificou-se, em relação à segunda pergunta ("Você cursou o Ensino Fundamental e o Ensino Médio na mesma escola?"), que apenas três ex-alunos Waldorf mudaram de escola, porém, de forma atípica ao que costumava ocorrer nos 
anos 90 , período em que lecionamos na escola. Naquela época, era comum que os pais mantivessem os alunos na pedagogia Waldorf do Jardim de Infância até o final do Ensino Fundamental e mudassem para outra escola no Ensino Médio, visando um melhor preparo para o vestibular. Curiosamente, no grupo pesquisado, os três ex-alunos que mudaram de escola fizeram o caminho oposto, isto é, ingressaram na pedagogia Waldorf no final do Ensino Fundamental ou no início do Ensino Médio.

Esses ex-alunos (Caio, Caroline e Júlia 1) consideraram a mudança boa. Caroline escreveu que "do terceiro ano em diante estudei na Escola Waldorf Rudolf Steiner e senti uma grande diferença na forma de ensino, pude compreender muito melhor as matérias" e a Julia, que mudou de escola na $7^{\text {a }}$ série, considerou que "a mudança foi muito boa, até ouso dizer que a melhor coisa que já me aconteceu!". O Caio não teceu nenhum comentário, apesar de ter assinalado que a mudança foi boa.

Onze alunos do primeiro grupo mudaram de escola, sendo que apenas dois (Amanda 1 e Danielle) consideraram a mudança ruim. Amanda 1 escreveu que foi separada de todos os seus amigos e colocada em uma sala "com somente desconhecidos" e a Danielle comentou que teve que fazer novas amizades. Com exceção de dois alunos que consideraram a mudança indiferente (Mateus e Suellen), os demais consideram que foi bom (Amanda 2, Gabriel, Guilherme, Igor, Lilian, Lizandra e Nathalia 1). A Amanda 2 comentou que alguns amigos mudaram de escola com ela e que "queria mudar, conhecer novos ambientes". O Guilherme escreveu: "conheci novas pessoas, fiz novas amizades". E a Lilian comentou que, no caso dela, a mudança foi boa "porque conheci outra cidade, novas pessoas outros pensamentos". 
Oito alunos do segundo grupo mudaram de escola, sendo que um considerou a mudança indiferente (Nathalia 2) e os demais consideraram a mudança boa (Daphine, Emanuelle, Larissa, Paloma, Sidney, Talita e Val). Os comentários são bem semelhantes ao primeiro grupo. Daphine comentou que "todas as escolas que eu estudei sempre foram boas, aliás, ótimas, através delas e dos ensinamentos que tive hoje sou quem sou". Paloma explicou que foram três escolas diferentes e escreveu: "conheci pessoas novas, outros ensinamentos". Talita escreveu: "encontrei novos ciclos de amizade e aprendi uma nova rotina". Para Val, a mudança permitiu conhecer novos lugares e fazer novas amizades.

A rotatividade foi maior entre os ex-alunos formados por outras pedagogias, porém, a adaptação a novas situações e a necessidade de criar novos laços de amizade, entre outros, foi satisfatória, não representando um problema para os participantes em geral, exceto para a Danielle e Júlia 1.

A terceira pergunta pedia aos participantes que assinalem as atividades praticadas por eles até o final do Ensino Médio indicando como opções: canto, pintura, dança, teatro, desenho, ginástica, artesanato, tricô, flauta, tapeçaria jardinagem, modelagem e marcenaria. Esperava-se verificar o contato destes alunos com atividades artísticas diversas e a expectativa era que os ex-alunos Waldorf assinalassem todas as atividades propostas e que incluíssem outras. De fato, quatro ex-alunos Waldorf assinalaram todas as atividades (Carol, Caroline, Isabela e Júlia 2). A Marina só não assinalou marcenaria e duas alunas acrescentaram litografia, lapidação, metal e arte da fala (Caroline e Marina). Porém, os demais alunos deixaram de assinalar algumas atividades, variando de aluno para aluno a atividade não assinalada. Não se sabe se houve alguma alteração no currículo tornando 
algumas atividades não obrigatórias, nem era o escopo desta tese. De qualquer forma, comprovou-se que a pedagogia Waldorf oferece todas as atividades previstas e outras citadas pelas ex-alunas Caroline e Marina.

No primeiro grupo de ex-alunos formados por outras pedagogias, Gabriel não assinalou nenhuma das atividades relacionadas, mas acrescentou futebol, inglês e pacote Office; o Igor assinalou apenas canto, mas citou futebol, handebol, natação e informática; o Guilherme assinalou apenas desenho e não acrescentou nenhuma outra atividade. Os demais alunos assinalaram de duas a quatro das atividades relacionadas e três deles citaram outras atividades: a Cibele aprendeu arte no muro; a Lizandra teclado; e o Mateus capoeira.

No segundo grupo de ex-alunos formados por outras pedagogias, dois alunos não assinalaram nenhuma das atividades relacionadas: a Elizabete e o Pedro, sendo que o Pedro acrescentou futebol. Três alunos assinalaram apenas desenho (Elaine, Sidney e Val) e um aluno assinalou apenas canto (Larissa), sendo que nenhum deles acrescentou outras atividades. Os demais alunos assinalaram de três a sete das atividades relacionadas. Daphine acrescentou rugby e, Paloma, violão.

Acreditava-se que muitas atividades não eram oferecidas por outras pedagogias, entre elas, tapeçaria, tricô e marcenaria. Comprovou-se que, de fato, nenhum aluno dos dois grupos formados por outras pedagogias praticou tapeçaria na escola, porém, encontramos no segundo grupo uma aluna que assinalou tricô e marcenaria (Paloma).

Verificou-se que as atividades artísticas, manuais e instrumentais oferecidas em uma escola Waldorf superam as oferecidas por outras pedagogias, porém, percebe-se uma valorização de atividades deste tipo em outras pedagogias. 
Lembramos que estamos analisando ex-alunos formados por escolas públicas e estaduais da zona oeste de São Paulo. De qualquer forma, a diferença quantitativa entre os grupos é grande. Por exemplo, canto foi assinalado por todos os ex-alunos Waldorf, por apenas três ex-alunos do primeiro grupo e por apenas três ex-alunos do segundo grupo; artesanato foi assinalado por onze ex-alunos Waldorf, por apenas um ex-aluno do primeiro grupo e por três alunos do segundo grupo; modelagem foi assinalado por treze ex-alunos Waldorf e por apenas um aluno de cada um dos grupos de ex-alunos formados por outras pedagogias.

A quarta pergunta ("Como você avalia sua vida até o final do Ensino Médio?") visava aferir se houve uma relação de afetividade com a vida escolar. Acreditava-se que os ex-alunos Waldorf tenderiam às duas respostas mais positivas: "excelente" ou "bom", enquanto que alguns alunos formados por outras pedagogias poderiam responder de forma negativa ou indiferente. Isto não ocorreu. Nenhum ex-aluno considerou o período escolar negativo ou indiferente, porém, houve uma diferença significativa entre os participantes do segundo grupo. Dez ex-alunos Waldorf assinalaram excelente, oito ex-alunos do primeiro grupo e apenas três ex-alunos do segundo grupo de ex-alunos de outras pedagogias. Três ex-alunos Waldorf assinalaram boa, seis ex-alunos do primeiro grupo e onze ex-alunos do segundo grupo. Pode-se concluir que a afetividade foi boa em todos os grupos, porém maior entre os ex-alunos Waldorf e menor entre os ex-alunos do segundo grupo.

A quinta questão ("Há alguma atividade realizada na escola da qual você tem saudades?') visava aferir se algum aluno sentia saudades de alguma atividade relacionada à leitura literária. Apenas dois alunos não-Waldorf, pertencentes ao segundo grupo citaram atividades relacionadas à leitura literária. A Larissa escreveu: 
que "adorava ficar na biblioteca" e a Nathalia 2 sente saudades de "leitura em grupo ao ar livre". Duas formas distintas de ler, uma introspectiva e em local fechado, a outra em grupo em local aberto.

No caso dos ex-alunos Waldorf, com exceção do aluno Gabriel, todos os demais citaram que sentiam saudades de alguma atividade. Nove deles mencionaram sentir saudades das atividades artísticas, dois mencionaram sentir falta da maneira de ensinar, cinco mencionaram esportes ou Educação Física e quatro atividades relacionadas à música. Sendo que um mesmo aluno citou mais de uma atividade: "Ter aulas de artes, que era uma pausa para a correria do mundo" (Bruna); "Esporte e aulas de história/geografia" (Caio); "Campeonatos esportivos, treinos esportivos, coral" (Carol); "Praticamente todas as atividades artísticas" (Caroline); "Todo o currículo de artes, inclusive canto" (Clara); "O modo de ensinar dos nossos professores" (Daniel); "Tenho saudades do coral e da Educação Física" (Isabela); "Todas as aulas de artes e ter acesso a todos os materiais e, por incrível que parece, das aulas de Educação Física" (Julia 1); "Artes e esportes no geral" (Júlia 2); "Quase todas as artísticas, e no geral, a riqueza na maneira de se ensinar as outras" (Marina); "Sinto saudades de quase todas as atividades da escola... Das artes, eurritmia e música principalmente” (Sofia 1); “Artes” (Sofia 2 e Tobias).

Oito alunos do primeiro grupo formado por outras pedagogias também se manifestaram, sendo que a maioria sente falta de atividades físicas e suas respostas foram mais sucintas: "Gincanas escolares" (Bruna); "Todas" (Cibele); "Campeonatos interescolas" (Gabriel); "Futebol e handebol” (Igor); "Educação Física” (Lizandra); "Sinto saudades da capoeira" (Mateus); "Teatro" (Raquel) e "Uma semana que a escola faz atividade de brincadeira" (Suellen). 
Dos dez alunos do segundo grupo de ex-alunos formados por outras pedagogias que se manifestaram, duas citaram a leitura, como já foi mencionado anteriormente, e os demais variaram entre atividades físicas ou relacionadas ao ensino das disciplinas: "Jogar rugby com os amigos" (Daphine); "Aulas práticas de Educação Física” (Elaine); "Educação Física” (Marcos), "Aula de infância” (Paloma), "Ir para passeios, Hopi Hari entre outros" (Pedro); "Dos debates que fazíamos na aula" (Sarah); "Biologia" (Sidney) e "Feira de ciências e arte" (Talita).

Percebe-se a importância da arte para os ex-alunos Waldorf e o quanto atividades diferenciadas propostas pelas escolas em geral, como o caso do rugby e da capoeira, se constituíram em um diferencial na vida dos alunos. Ao mesmo tempo, volta-se à velha questão de que é necessário rever a forma como a leitura literária está sendo praticada nas escolas, visto que em um grupo de trinta e nove alunos, apenas dois sentem saudades de atividades relacionadas à leitura literária.

Na sexta pergunta ("Você se considera uma pessoa: otimista, realista ou pessimista?') esperava-se que os ex-alunos Waldorf fossem mais otimistas que os demais alunos, o que não se confirmou. Apenas cinco ex-alunos Waldorf se declararam otimistas, sendo que, no primeiro grupo de ex-alunos de outras pedagogias, dez se consideram otimistas e, no segundo grupo, seis. Nove ex-alunos Waldorf se declararam realistas, quatro no primeiro grupo e oito no segundo grupo. Dificilmente alguém se declararia pessimista, de qualquer forma, a maioria dos exalunos Waldorf declarou-se realista.

A sétima pergunta (“Você pratica esportes ou faz ginástica?') tinha como objetivo aferir se os participantes eram ativos ou sedentários. Verificou-se que os exalunos Waldorf são mais ativos do que os demais. Sete deles responderam "mais de 
uma vez por semana" contra dois do primeiro grupo e três do segundo grupo.

A oitava pergunta visava aferir o percentual de ex-alunos que já ingressaram no mercado de trabalho e o grau de satisfação destes ex-alunos com o trabalho executado. Verificou-se que apenas três ex-alunos Waldorf estão trabalhando, sendo que um deles gosta muito do trabalho que faz (Clara) e os outros dois responderam "mais ou menos" (Caroline e Tobias). Doze alunos do primeiro grupo de ex-alunos formados por outras pedagogias já ingressaram no mercado de trabalho, sendo que dois declararam gostar muito do trabalho que fazem (Amanda 2 e lgor), três assinalaram "na maioria das vezes" (Cibele, Gabriel e Lizandra), cinco "mais ou menos" (Amanda 1, Danielle, Mateus, Nathalia 1 e Suellen), um respondeu "sim" (Guilherme) e o outro "não" (Lilian). Onze alunos do segundo grupo declarou trabalhar, sendo que três declararam "gostar muito" (Daphine, Emanuelle e Marcos), quatro "na maioria das vezes" (Elaine, Larissa, Paloma e Talita); três assinalaram "mais ou menos" (Nathalia 2, Pedro e Sarah) e o Sidney respondeu "sim".

Na nona pergunta (“Você já escolheu sua profissão?”) esperava-se aferir se algum ex-aluno Waldorf optaria por Administração, que é a profissão predominante do grupo não formado pela escola Waldorf. Isto aconteceu, visto que o aluno Caio quer ser Administrador. Esperava-se, também, que os ex-alunos Waldorf já tivessem escolhido uma profissão e que muitos deles tivessem escolhido atividades artísticas ou nas áreas de humanas. Além do Caio, sete ex-alunos Waldorf já escolheram a profissão, porém apenas três optaram por atividades artísticas. A Clara quer ser atriz, a Marina quer trabalhar com design e teatro e, a Sofia 1, quer ser cineasta. $O$ Daniel quer ser piloto de aviões, o Gabriel quer ser engenheiro elétrico, a Isabela quer trabalhar com políticas públicas para criar projetos de melhoria para a 
sociedade e a Sofia 2 quer ser psicóloga.

Nos grupos de alunos formados por outras pedagogias, apesar dos alunos já estarem na faculdade cursando Administração, Gestão de Recursos Humanos e Gestão Financeira, alguns declararam não terem ainda escolhido a profissão e, outros, escolheram profissões que não condizem com os cursos em que estão matriculados. No primeiro grupo, há oito alunos nesta situação: cinco alunos declaram não terem ainda escolhido uma profissão (Cibele, Igor, Lilian, Nathalia 1 e Raquel), o Igor quer trabalhar com Marketing Esportivo em times de futebol, a Lizandra quer ser Analista Contábil e o Mateus quer ser Militar. A indefinição foi menor no segundo grupo, no qual apenas três ainda não escolheram a profissão (Drielli, Elaine e Talita), a Daphine quer ser Secretaria Bilíngue, a Nathalia 2 quer ser professora e o Pedro quer ser Militar.

A décima pergunta (“Você está satisfeito com a sua aparência?") buscava aferir o percentual de alunos satisfeitos ou insatisfeitos com sua aparência. Esperava-se que a maioria dos ex-alunos Waldorf respondessem "sempre" e que as repostas dos demais alunos variasse. As respostas não coincidiram com as expectativas. Em primeiro lugar, porque um ex-aluno Waldorf respondeu raramente (Caroline), um ex-aluno do primeiro grupo também (Amanda 1) e nenhum dos exalunos do segundo grupo formado por outras pedagogias assinalou esta opção. E, em segundo lugar, pelo fato de apenas três ex-alunos Waldorf assinalarem sempre (Caio, Clara e Gabriel), em relação à um ex-aluno do primeiro grupo (Cibele) e à sete do segundo grupo (Daphine, Elizabete, Larissa, Marcos, Paloma, Sarah e Sidney). Apesar disso, sete ex-Waldorf responderam quase sempre (Carol, Daniel, Isabela, Julia 2, Marina e as duas Sofias), nove do primeiro grupo (Amanda 2, 
Brunam Daniele, Gabriel, Guilherme, Lizandra, Mateus, Raquel e Suellen) e quatro do segundo grupo (Elaine, Emanuelle, Nathalia 2 e Talita). Com relação às respostas sempre ou quase sempre o resultado da comparação dos ex-Waldorf com o segundo grupo foi quase exatamente o oposto, visto que três ex-Waldorf responderam sempre e sete quase sempre, enquanto no segundo grupo sete responderam sempre e quatro quase sempre. Ao mesmo tempo, verificou-se um grau bom de satisfação consigo mesmo em todos os grupos pesquisados, visto que pelo menos dez participantes em cada grupo selecionaram sempre ou quase sempre.

Em relação à pergunta "Você se considera uma pessoa interessante?", o resultado foi melhor entre o primeiro e o segundo grupo de alunos não-Waldorf, no qual dez a onze alunos concentraram suas respostas em sempre e quase sempre, sendo a maior concentração para quase sempre. Sempre foi assinalado por três exWaldorf (Caroline, Isabela e Marina), por dois participantes do primeiro grupo (Gabriel e Suellen) e por quatro do segundo grupo (Elizabete, Marcos, Paloma e Sarah). Quase sempre foi assinalado por três ex-Waldorf (Carol, Clara e Daniel), por oito alunos do primeiro grupo (Amanda 2, Bruna, Cibele, Guilherme, Igor, Lilian, Lizandra e Raquel) e por sete do segundo grupo (Daphine, Elaine, Emanuelle, Larissa, Nathalia 2, Sidney e Talita). Apenas um ex-aluno do primeiro grupo assinalou raramente (Nathalia 1). Os demais oito participantes ex-Waldorf, três do primeiro grupo e três do segundo grupo, assinalaram às vezes. Portanto, o percentual de alunos que se consideram interessantes é maior entre os não-Waldorf.

O objetivo da décima segunda pergunta ("Você sabe lidar com suas emoções?') era aferir o percentual de alunos que se consideravam emocionalmente equilibrados. A expectativa era que a maioria dos ex-alunos Waldorf respondesse 
"sempre" ou "quase sempre". De fato, estas foram as opções de dez participantes, porém, apenas um assinalou sempre (Daniel) e o resultado foi muito próximo do resultado com o segundo grupo de não-Waldorf no qual nove alunos assinalaram quase sempre. Três ex-Waldorf assinalaram às vezes (Caio e as Julias) e o Gabriel optou por raramente. No primeiro grupo de ex-alunos formados por outras pedagogias, apenas o Igor assinalou sempre, quatro alunos assinalaram quase sempre (Bruna, Cibele, Gabriel e Mateus) e os demais alunos assinalaram às vezes. No segundo grupo, nove assinalaram quase sempre, quatro às vezes (Elaine, Emanuelle, Paloma e Sidney) e apenas a Talita assinalou raramente.

A questão chave para esta tese ("Você tem o hábito de ler?") visava aferir se os ex-alunos Waldorf mantinham o hábito de ler e se os demais alunos tinham ou não esse hábito. Curiosamente, o único aluno que respondeu nunca pertence ao grupo de ex-alunos Waldorf (Gabriel). A quantidade de alunos que responderam sempre foi praticamente a mesma nos três grupos, porém com um aluno a menos no grupo de ex-alunos Waldorf: cinco ex-Waldorf (Caio, Júlia 2, Marina, Sofia 1 e Tobias), seis em cada um dos outros dois grupos (Amanda 1, Amanda 2, Bruna, Lilian, Lizandra e Suellen no primeiro grupo e Daphine, Elizabete, Emanuelle, Larissa, Nathalia 2 e Val no segundo grupo). Um aluno em cada um dos grupos respondeu quase sempre (Caroline, ex-Waldorf, Raquel do primeiro grupo e Sarah do segundo). Raramente foi assinalado por quatro ex-alunos Waldorf (Bruna, Daniel, Isabela e Sofia 2), por cinco ex-alunos do primeiro grupo (Cibele, Gabriel, Guilherme, Igor e Nathalia 1) e por dois ex-alunos do segundo grupo (Drieli e Pedro). Os demais responderam às vezes (três Waldorf, dois do primeiro grupo e cinco do segundo grupo). 
Apesar do contato com a literatura oral e escrita durante toda a vida escolar, os ex-alunos Waldorf que participaram da pesquisa demonstraram que não mantém o hábito de ler, visto que apenas seis responderam sempre ou quase sempre. Número muito próximo do resultado dos dois grupos de ex-alunos de outras pedagogias que totalizaram sete em cada grupo. Isto mostra que há mais semelhanças do que diferenças, com relação aos hábitos de leitura literária, entre os participantes que farão parte da experiência de recepção de leitura proposta nesta tese. Retomaremos este ponto após a análise da experiência estética de recepção de leitura.

O objetivo da décima quarta questão era aferir os hábitos de leitura literária dos grupos analisados e, principalmente, verificar se os participantes lembravam dos nomes dos autores lidos. Esperava-se que os ex-alunos Waldorf assinalassem a maioria dos autores citados e que os demais alunos marcassem apenas dois ou três autores nacionais.

Os resultados confirmaram as expectativas com relação aos ex-alunos Waldorf. Apenas Balzac e Flaubert não foram assinalados por eles. Além disso, três alunos citaram outros autores: Carol escreveu: "li para o TCC ${ }^{101}$ Bauman $^{102 ",}$ Caroline acrescentou George Orwell ${ }^{103}$ e Lon L. Fuller ${ }^{104}$, e Marina escreveu: "Vários! Caio Abreu ${ }^{105}$, Aldous Huxley ${ }^{106}$, George Orwell, Kundera ${ }^{107}$ etc.". Os

\footnotetext{
${ }^{101}$ Os alunos da Pedagogia Waldorf realizam um trabalho de conclusão de curso (TCC) no $12^{\circ}$ ano, último ano escolar desta pedagogia.

102 O sociólogo Zygmunt Bauman nasceu na Polônia em 1925. Mudou-se para a Inglaterra em 1971. É um dos líderes da chamada "sociologia humanística". Defensor da literatura como forma de compreensão da condição humana.

${ }^{103}$ Pseudônimo de Eric Arthur Blair (1903-1950). Nasceu em Bengala na Índia. Socialista, jornalista e escritor, viveu na Inglaterra, em Paris e na Espanha. Sua obra mais popular, A Revolução dos Bichos, foi publicada em 1945.

104 Lon Luvois Fuller (1902-1978) nasceu nos Estados Unidos. Filosofo e professor de jurisprudência em Harvard.

${ }^{105}$ Caio Fernando Abreu (1948-1996) nasceu em Santiago, no Rio Grande do Sul. Foi jornalista, dramaturgo e
} 
resultados também mostraram que os alunos de outras pedagogias conhecem Shakespeare (oito no primeiro grupo e sete no segundo) e Camões (sete no primeiro grupo e cinco no segundo).

Miguel de Cervantes foi assinalado pelo Igor do primeiro grupo. Machado de Assis foi lido por doze alunos do primeiro grupo e nove do segundo. Clarice Lispector faz parte do repertório de nove alunos do primeiro grupo e de seis alunos do segundo grupo. Monteiro Lobato foi assinalado por doze alunos do primeiro grupo e onze do segundo grupo. Dez alunos do primeiro grupo e sete do segundo indicaram Fernando Pessoa.

A relação de autores foi complementada por três participantes do primeiro grupo e por sete participantes do segundo grupo. Gabriel incluiu Jaime Kemp ${ }^{108}$, Mateus completou com Jorge Amado e Nathália 1 com Nicollas Spark ${ }^{109}$. Elizabete acrescentou “John Boyne ${ }^{110}$, Walcyr Carrasco, Jane Austen"111, José de Alencar, C. Hunter ${ }^{112 ",}$ Emanuelle citou Augusto Cury ${ }^{113}$, Larissa lembrou da escritora brasileira de livros infantis Ruth Rocha, Nathalia 2 complementou a lista com Raphael Dracon $^{114}$ e João de Andrade ${ }^{115}$, Sarah acrescentou Andrea Del Fuego ${ }^{116}$ e o Sidney

escritor.

106 Aldous Leonard Huxley (1894-1963) escritor inglês, autor de Admirável Mundo Novo.

107 Milan Kundera nasceu na Tchecoslováquia em 1929. Exilou-se na França em 1975. Autor do livro $A$ Insustentável Leveza do Ser.

108 Jaime Kemp nasceu na Califórnia. Reside no Brasil desde 1967. Fundou a Associação Lar Cristão em 1998.

109 Nichollas Charles Sparks nasceu em 1965. Escritor, roteirista e produtor americano.

110 John Boyne romancista irlandês nascido em 1971.

111 Jane Austen (1775-1817) romancista inglesa.

112 Pseudônimo de Christie Craig, fotografa jornalística, escritora e professora, nasceu no Alabama e vive atualmente no Texas.

${ }^{113}$ Augusto Jorge Cury nasceu em Colina, no Estado de São Paulo, em 1958. Médico, psiquiatra, psicoterapeuta e escritor. Foi considerado pelo Jornal a Folha de São Paulo o autor brasileiro mais lido da década. Pesquisador na área de qualidade de vida e desenvolvimento da inteligência, desenvolveu a teoria da inteligência Multifocal, sobre o funcionamento da mente humana no processo de construção do pensamento e na formação de pensadores.

114 Raphael Dracon nasceu no Rio de Janeiro em 1981. É roteirista profissional, editor e autor de literatura fantástica, ficção, suspense e romances com elementos sobrenaturais.

115 João Batista de Andrade nasceu em Ituiutaba, Minas Gerais, em 1939. É diretor, produtor de cinema e 
citou Pierre Weil ${ }^{117}$ e Roland Tompakow.

Na décima quinta questão, pretendia-se verificar se a quantidade de medos apontados pelos ex-alunos Waldorf era menor do que a quantidade apontada pelos demais alunos. Três ex-alunos Waldorf não assinalaram nenhum dos medos propostos na pesquisa, mas eles citaram outros medos. A Marina disse ter medo de não passar na Fuvest neste ano; a Sofia 1 escreveu "não tenho nenhum desses medos muito presentes, mas já senti todos eles" e o Tobias tem "medo de não ser suficiente". Dois participantes do primeiro grupo de ex-alunos formados por outras pedagogias, também não assinalaram nenhum medo da relação, mas complementaram: o Guilherme tem medo de perder pessoas próximas e o Igor tem medo de viver na miséria. Apenas uma participante do segundo grupo não assinalou nenhum medo, a Sarah, mas citou que tem medo de perder um ente querido.

Os dois medos mais assinalados pelos ex-alunos Waldorf foram o medo de morrer e o medo de sofrer algum acidente, com seis participantes em cada um deles, sendo que três alunos assinalaram os dois. No primeiro grupo de ex-alunos, o medo mais assinalado foi o de animais peçonhentos escolhido por oito deles, medo de morrer por sete e medo de sofrer algum acidente por seis, sendo que dois participantes assinalaram os três. No segundo grupo há sete participantes que assinalaram medo de animais peçonhentos e medo de sofrer algum acidente. Há uma equivalência entre os participantes em relação ao medo de sofrer algum

televisão, roteirista e escritor. Foi secretario estadual de Cultura de São Paulo na gestão de Geraldo Alckmin.

${ }^{116}$ Nasceu em São Paulo, em 1975. Andréa del Fuego é escritora e jornalista, escreve contos, romances e livros infantis e juvenis. Em 2011 recebeu o prêmio José Saramago por seu primeiro romance, Os Malaquias.

117 Pierre Weil (1924-2008) nasceu em Estrasburgo, Paris. Educador e Doutor em Psicologia pela Universidade de Paris, residiu no Rio de Janeiro de 1949 a 1958 onde foi Chefe da Seção de Orientação e Seleção Profissional do Departamento Nacional do Senac e, posteriormente, Chefe do Consultório Psicopedagógico do Instituto Pestalozzi. Em 1958 mudou-se para Belo Horizonte como professor da UFMG. Em 1987 mudou-se para Brasília e assumiu a Presidência da Fundação Cidade da Paz da Universidade Holística para a Paz - UNIPAZ. Seu livro mais conhecido é O Corpo Fala e foi escrito em parceria com Roland Tompakow. 
acidente, que foi assinalado por seis ex-alunos Waldorf, seis ex-alunos do primeiro grupo e sete ex-alunos do segundo grupo. Nem um ex-aluno Waldorf assinalou mais do que três tipos de medo, enquanto nos dois outros grupos o máximo de medos assinalados foi quatro.

Entre os comentários dos ex-alunos Waldorf, gostaríamos de citar o de Caroline que tem medo de ficar sozinha e de perder pessoas que ama, o da Clara que tem medo de ser infeliz e o da Júlia 1 que tem medo de tornar-se uma pessoa solitária. No grupo um, além dos medos citados pelo Guilherme e pelo lgor, já mencionados, a Amanda 1 tem medo de ficar sozinha. No grupo dois a Daphine tem medo de magoar alguém sem perceber, a Elaine escreveu que tem medo de não ser feliz com as suas escolhas, a Elizabete tem medo que alguém que ela ame muito morra, o Marcos tem medo de perder familiares, a Nathalia 2 tem medo de não trabalhar, o Pedro tem medo de perder pessoas importantes para ele e a Sarah tem medo de perder um ente querido.

As três últimas perguntas do questionário: "Defina a velhice em uma única frase", "Defina a morte em uma única frase" e "Defina a vida em apenas uma frase" eram questões abertas em que se esperava respostas variadas. Porém, pretendiase verificar, por meio de análise de conteúdo, se era possível analisar semelhanças e diferenças entre os grupos analisados.

Apenas dois ex-alunos Waldorf têm uma visão pessimista sobre a velhice: o Caio que considera a velhice difícil e a Júlia 2 que escreveu "decadência". Os demais ex-alunos escreveram frases bastante interessantes: "Ter um conhecimento enorme sobre a vida" (Bruna); "A experiência espiritual, desgaste material" (Carol); "Ter sabedoria para compreender o mundo as pessoas e a mim mesma" (Caroline); 
"Experiência" (Clara); "Parte final da vida em terra" (Daniel); "Parte final da vida natural” (Gabriel); "Auge do pensar e da experiência” (Isabela); "Longa experiência de vida! (frase do meu irmão Theo de 9 anos)" (Júlia 1); "É o amadurecimento do corpo e da alma" (Marina); "Olhar tudo o que fiz, senti e pensei de uma outra maneira" (Sofia 1); "Conhecer todas as facetas de viver" (Sofia 2) e "Uma mudança de ritmo e de costumes" (Tobias).

No primeiro grupo de ex-alunos de outras pedagogias, apenas a Bruna teve uma visão mais pessimista associando a velhice ao medo da solidão. As demais respostas foram variadas: "Experiência de uma vida" (Amanda 1); "Não importa quanto tempo passe, você ainda não viveu o suficiente" (Amanda 2); "Ser aquilo que a vida te ensinou" (Cibele); "Visão de um mundo diferente" (Danielle); "Chegará para todos" (Gabriel); "Experiências" (Guilherme); "Conhecer de tudo um pouco" (Igor); "Sabedoria" (Lilian); "Acúmulo de experiências de vida" (Lizandra); "A velhice depende da juventude" (Mateus); "Viver o hoje porque o amanhã a Deus pertence" (Nathalia 1); "Os idosos de hoje, somos nós amanhã" (Raquel) e "Experiência de vida" (Suellen).

No segundo grupo não-Waldorf apenas a Drielli vê a velhice de forma negativa; ela escreveu, simplesmente, "solidão". As respostas dos demais alunos variaram e algumas foram semelhantes às respostas dadas pelos alunos Waldorf. As respostas foram: "Vivido o suficiente, mas sempre apto para aprender mais" (Elaine); "Auto conhecimento de como a vida é" (Marcos); "Uma grande sabedoria" (Paloma); "Conhecer de tudo um pouco" (Pedro); "Tudo o que de bom, que podemos aproveitar" (Sarah); "Amadurecimento, tenho medo de envelhecer por conta da morte" (Sidney); "Viver todos os dias como se fossem os últimos" (Talita) e "Tempo 
de aproveitar o melhor da vida" (Val).

Percebe-se, em alguns participantes do grupo formado pela pedagogia Waldorf, uma maior espiritualidade nas definições dadas à velhice. O mesmo pode ser verificado com relação à definição da morte: "A libertação da alma" (Carol); "Evolução do espírito” (Caroline); “Uma passagem” (Daniel); "O nascimento em outro plano" (Marina); "Uma transição" (Tobias). Em relação aos alunos formados por outras pedagogias, não detectamos esta espiritualidade nas respostas dadas à velhice, mas apareceu uma ideia de continuidade nas definições dadas à morte por dois alunos do primeiro grupo e por três alunos do segundo grupo. No primeiro grupo: "Chama para um novo recomeço" (Igor) e "Enigmática, que traz medo, mas pode ser um impulso para a vida" (Mateus). E, no segundo grupo: "No céu será paz, alegria, descanso e gozo" (Daphine); "Passagem para o infinito" (Larissa) e "Ter vida no céu ou no inferno" (Pedro). Embora, no segundo grupo, as definições estejam mais ligadas à religiosidade.

Consideramos interessante citar as demais definições dadas à morte pelos participantes, como forma de familiarizar os leitores com o perfil dos entrevistados e a diversidade das respostas. Iniciando com os ex-alunos Waldorf: "Um vazio que todos experimentarão" (Bruna); "Talvez doloroso, talvez difícil, talvez não" (Caio); "Se não fosse ela, a vida seria totalmente diferente" (Clara); "O fim de uma vida" (Gabriel); "Um lugar desconhecido ao qual não tenho vontade de ir" (Isabela); "Final de sua missão no mundo!” (Júlia 1); "Enfim” (Júlia 2); "O que nunca vou saber” (Sofia 1) e "Presente em tudo na vida" (Sofia 2).

As demais descrições do primeiro grupo foram: "Final de um ciclo" (Amanda 1); "Falta de vida" (Amanda 2); "Medo do que pode acontecer após a morte" (Bruna); 
"Aproveite a vida até que essa hora chegue" (Cibele); "Missão cumprida na terra" (Danielle); "Quando você menos espera" (Gabriel); “Tudo tem fim” (Guilherme); “Tristeza e perda” (Lilian); “Dor, pois perder um ente querido é uma das piores coisas da vida" (Lizandra); "Tudo tem um fim" (Nathalia 1); "Devemos fazer de tudo para sermos felizes hoje, pois não sabemos se o amanhã chegará" (Raquel) e "Tudo na vida tem uma solução, menos para a morte, porque é a única certeza que um dia vai acontecer (Suellen). No segundo grupo: "Tristeza” (Drieli); "Tarde demais para se arrepender" (Elaine); "Morrer é a nossa única certeza” (Elizabete); "Mesmo achando que somos eternos, a morte é inevitável (Emanuelle); "Parte da vida" (Marcos); "Ocorrência natural, porém muito temida" (Nathalia 2); "Descansar em paz" (Paloma); "Não há mais chances, é a única certeza de viver em paz" (Sarah), "Fim" (Sidney); "Nunca sinta medo da morte, sinta vontade de realizar todos os seus sonhos" (Talita) e "Momento de descansar em paz" (Val).

Apenas um participante definiu a vida de forma negativa, a Caroline, formada pela pedagogia Waldorf: "Um longo e duro aprendizado". Um participante de cada grupo foi mais neutro em sua definição: o Gabriel, formado pela Waldorf, definiu a vida como um intervalo entre a vida e a morte; o Guilherme, do primeiro grupo, escreveu "Momentos bons e ruins" e a Elizabete, do segundo grupo, "A vida tem momentos bons e ruins".

As demais respostas foram bem variadas. Do grupo formado pela pedagogia Waldorf temos: "A chance de cada um ser qualquer coisa e protagonizar sua própria vida" (Bruna); "Feita para ser vivida" (Caio); "A vida é um conjunto de experiências que montam nosso ser" (Carol); "Ela é seu próprio sentido, pois é absoluta" (Clara); "O inexplicável" (Daniel); "Uma viagem onde acontece de tudo um pouco (ou muito)" 
(Isabela); "Sorrir, arriscar, errar, superar e recomeçar!" (Júlia 1); "Cor" (Júlia 2); "A oportunidade de evolução do ser" (Marina); "Dúvidas, decisões e incertezas que nos levam ao que somos" (Sofia 1); "Caminho no qual se deve buscar sempre o desenvolvimento como ser" (Sofia 2) e "Uma experiência única" (Tobias).

As definições para a vida dada pelo primeiro grupo formado por ex-alunos de outras pedagogias foram: "Fazer com que suas ações sejam boas para suas lembranças" (Amanda 1); "Sorria mais, transmita a paz e não desista jamais" (Amanda 2); "A vida é intensa, devemos vive-la de forma sensata” (Bruna); "A vida é agora, aproveite!" (Cibele); "Liberdade de viver seus sonhos” (Danielle); "Sonhar, viver e todo dia agradecer" (Gabriel); "Aproveitar cada minuto como se fosse o último" (Igor); "Momentos inesquecíveis, com intensidade, uma corrida contra o tempo" (Lilian); "Viver da melhor forma que pudermos" (Lizandra); “Uma dadiva divina" (Mateus); "Saiba aproveitar o dia/momento por mais simples que seja" (Nathalia 1); "A vida é bela" (Raquel) e "Vive o dia de hoje que o amanhã pertence a Deus" (Suellen).

No segundo grupo tivemos: "A vida é feita de experiências e aprendizado" (Daphine); "Mistério" (Drieli); "Enquanto vida tiver, viva como se fosse seu último dia" (Elaine); “É preciso amar as pessoas como se não houvesse amanhã (Renato Russo)" (Emanuelle); "Sempre contínua" (Larissa); "Única para ser aproveitada ao máximo" (Lizandra); "Uma dádiva, que nem muitos sabem como aproveitar" (Nathalia 2); "Novos conhecimentos, experiência e um grande aprendizado" (Paloma); "Aproveitar cada minuto como se fosse o último" (Pedro); "Tudo o que se pode aprender, sonhar, a vida é expectativa de dias melhores" (Sarah); "Esperança" (Sidney); "Viver ao invés de sobreviver" (Talita) e "Aprender a cada dia coisas novas" 
(Val).

Pode-se perceber uma maior maturidade filosófica e um posicionamento enquanto ser, nas respostas dadas por seis ex-alunos Waldorf (Bruna, Carol, Clara e as duas Sofias), enquanto que não há, nos demais participantes formados por outras pedagogias, um posicionamento do ser em relação à vida. A vida é definida por eles de várias maneiras, sendo que alguns enfatizam a importância do sonho, da liberdade, outros enfatizam a importância das experiências e do aprendizado e alguns a consideram um desígnio ou uma dádiva divina.

Percebe-se uma maior originalidade nas respostas dadas pelos ex-alunos Waldorf às três últimas perguntas. Podemos ouvir suas vozes, há um posicionamento como ser, enquanto que em muitos alunos formados por outras pedagogias ouvimos slogans de ditos comuns. Há também mais erros de português entre os ex-alunos formados por outras pedagogias.

\subsection{APRESENTAÇÃO DOS RESULTADOS DA EXPERIÊNCIA ESTÉTICA DE RECEPÇÃO DE LEITURA}

A maior dificuldade encontrada para a análise da experiência estética de recepção de leitura foi a quantidade de ex-alunos Waldorf que aderiram à pesquisa. Apenas nove dos catorze alunos que responderam ao questionário um, em relação à trinta dos trinta e cinco ex-alunos formados por outras pedagogias. Para manter os critérios científicos e a coerência adotada para análise do primeiro questionário, deveríamos descartar cinco alunos do primeiro e do segundo grupos de alunos 
formados por outras pedagogias. Na verdade, deveríamos descartar apenas três participantes do primeiro grupo, visto que a Amanda 1 e a Suellen não compareceram para a experiência estética de recepção de leitura e um participante do segundo grupo, visto que a Emanuelle não compareceu na segunda etapa da pesquisa.

Decidimos excluir os participantes que responderam SEMPRE para a questão “Você tem o hábito de ler?", o que nos fez chegar em oito alunos em cada grupo. O nono participante deveria ser alguém que respondeu SEMPRE e o corte foi feito pela ordem alfabética. Desta forma, o primeiro grupo de não-Waldorf passou a ser formado pela Cibele, Daniele, Gabriel, Guilherme, Igor, Lizandra, Mateus, Nathalia 1 e Raquel. O segundo grupo passou a ser formado pela Drieli, Elaine, Marcos, Paloma, Pedro, Sarah, Sidney, Talita e Val. O grupo de ex-alunos Waldorf passou a ser representado pelo Caio, Carol, Caroline, Clara, Daniel, Gabriel, Júlia 1, Sofia 1 e Tobias.

Os dois primeiros poemas Pobre Vovô! e Vocês Acreditam? visavam trazer à consciência do adulto, lembranças ou representações do primeiro estágio de sua vida. Embora muito semelhantes em termos de sonoridade, abordavam temáticas diferentes: a velhice e os medos infantis, respectivamente. Além disso, o segundo poema trazia personagens presentes no imaginário infantil: bruxa, palhaço, fantasma, espantalho etc.

O primeiro poema Pobre Vovô! agradou os ex-alunos Waldorf. Nenhum deles assinalou que não gostou do poema, embora, também, não tenham assinalado a opção gostou muito. Seis deles assinalaram sim e três mais ou menos (Caio, Caroline e Daniel). O Caio escreveu "apesar de bem escrito, achei muito simplista" e 
a Caroline "o poema não mostrou muito impacto, porém a ilustração cativa e envolve, trazendo as pessoas para o ambiente". O Daniel não fez nenhum comentário, nem os demais alunos que assinalaram SIM.

No primeiro grupo, três participantes assinalaram que gostaram muito: a Cibele, o Guilherme e o Mateus, sendo que apenas o Mateus comentou "gostei muito do poema, muito interessante e chamativo, nota 10". Quatro participantes assinalaram SIM e dois deles teceram comentários: a Lizandra falou sobre a ilustração ("adorei a ilustração, mas poderia ter uma criança também para ilustrar e completar o poema") e a Raquel escreveu que "parece um poema bobo, mas para mim teve um grande significado" e complementou: "Hoje minha vó recebeu alta pois teve derrame e só quando acontece coisas assim damos valor aos nossos vovozinhos(as)". Dois participantes assinalaram mais ou menos (Gabriel e Nathalia 1), mas não fizeram nenhum comentário.

No segundo grupo, a Paloma gostou muito e escreveu "gostei do poema e da ilustração. Chama bastante a atenção". Sete participantes responderam sim e não teceram nenhum comentário. O Sidney assinalou que não gostou do poema e escreveu que "o poema é de difícil entendimento". É interessante notar que o Sidney escreveu que "tem medo de envelhecer por conta da morte" na questão que pedia para definir a velhice.

Com relação à ilustração do poema Pobre Vovô!, entre os ex-alunos Waldorf, a Sofia 1 assinalou que gostou muito, seis alunos assinalaram sim e dois assinalaram mais ou menos (Daniel e Tobias). No primeiro grupo de não-Waldorf, o Mateus assinalou que gostou muito, sete alunos assinalaram sim e o lgor não, embora não tenha feito nenhum comentário a respeito. No segundo grupo não- 
Waldorf três assinalaram que gostaram muito (Elaine, Marcos e Paloma), cinco assinalara sim e o Pedro assinalou mais ou menos, porém não comentou.

Cinco ex-alunos Waldorf assinalaram gostei muito do poema Vocês Acreditam? (Caroline, Clara, Daniel, Júlia e Sofia 1), três assinalaram sim e apenas o Tobias assinalou mais ou menos. Apenas o Caio, que assinalou sim, escreveu um comentário: "Gostei da posição em que o poema coloca o leitor, de pessoa brava; valente; como se nada o pudesse parar". No primeiro grupo de não-Waldorf, cinco participantes assinalaram gostei muito (Cibele, Gabriel, Guilherme, Igor e Mateus), sendo que apenas o Mateus comentou que "ajuda a entender que não devemos causar medos as crianças, muito bom me lembra a infância". Os demais participantes assinalaram sim e não fizeram nenhum comentário. No segundo grupo de não-Waldorf, apenas o Pedro assinalou sim, todos os demais assinalaram gostei muito e cinco deles escreveram comentários: a Drieli escreveu "Gostei muito do poema, por causa de suas rimas, que trazem muito mais graça e beleza ao texto"; a Elaine: "As rimas são muito bem adequadas e a riqueza de detalhes da ilustração, são dignos de elogio"; a Paloma: "Muito legal, a imaginação é capaz de inventar muitas coisas, até coisas bonitas e assustadoras"; o Sidney: "Poema criativo e muito bom para ser lido por crianças. Mostrando que as coisas ruins desse tipo não existem" e a Talita: "Te faz imaginar aquilo que te assusta citado no texto ao ver as imagens, associando a leitura e a ilustração".

Com relação à ilustração do poema Vocês Acreditam? apenas a Carol do grupo Waldorf assinalou mais ou menos e não comentou. Os demais ex-alunos Waldorf assinalaram sim e a Clara comentou que "A ilustração foi tão bem colocada que conforme ia lendo ia acompanhando as imagens". No primeiro grupo de ex- 
alunos formados por outras pedagogias, seis assinalaram ter gostado muito da ilustração e três assinalaram sim (Daniele, Lizandra e Nathalia 1). No segundo grupo, apenas o Pedro assinalou sim e todos os demais assinalaram gostei muito.

O livro Vi uma Estrela lá fora foi utilizado como uma passagem ou incorporação do Eu pelo corpo astral. Este movimento poderia ser assegurado pela interiorização do menino nos momentos de introspecção (Eu) ou exteriorização no contato com o mundo e com as sensações que o mundo pode causar (corpo astral). Lembrando que o Eu, ou anímico-espiritual, é considerado por Steiner como o portador do atuar e do querer e o corpo astral, ou corpo das sensações, como um mediador interno que irradia suas qualidades essenciais para o exterior. O corpo astral é portador de tudo o que dá prazer, sofrimento, alegria e dor, instintos, impulsos, paixões, enfim, todas as representações que comovem o homem, e é o corpo que o homem tem em comum com os animais. E como já foi dito, dentro e fora, interior e exterior, imersão e emersão, acompanham a trajetória do menino que tem medo de viver. Menino que tem vontade de se esconder, que sente dor, que chora, sente rejeição, mas também sente alegria, ri, se encanta com as belezas naturais, quer brincar, ter amigos, correr, ser feliz.

O texto permitiria ao nosso jovem adulto abandonar por alguns momentos o pensar puramente racional e voltar a pensar por meio de imagens, como quando começou a desvendar o mundo. Pensar por analogia, nutrido pelas imagens verbais e visuais propostas no livro Vi uma Estrela lá fora e seguindo o conselho proposto na última ilustração: "para escutar as emoções, resolver conflitos com flores e abraçar as estrelas".

Apenas o Gabriel, ex-aluno Waldorf, assinalou que não gostou da estória. Ele 
não fez nenhum comentário a respeito, mas foi ele que definiu a vida com a frase "intervalo entre o nascimento e a morte". Dois participantes assinalaram mais ou menos: o Daniel (ex-Waldorf) e o Gabriel (do primeiro grupo), mas eles não escreveram o motivo. Todos os demais participantes ou assinalaram sim ou gostei muito.

Entre os ex-alunos Waldorf que assinalaram gostei muito estão a Carol, a Caroline, a Clara e a Sofia 1. Todas elas escreveram algum comentário sobre o livro: a Carol: "a maneira como as palavras são dispostas encanta mais ainda as ilustrações"; a Caroline: "O livro é muito interessante, pois retrata sentimentos e momentos simples pelos quais todos passamos"; a Clara: "Achei interessante como o personagem expressa o desejo de se isolar, fugir. Mas ao encontrar alguém vê que isso não é um desejo real. Achei esse sentimento muito verdadeiro"; e a Sofia 1: "Apesar de não ser a típica história sempre feliz para crianças, é feito um lindo caminho entre ilustração/história". Os três ex-Waldorf que assinalaram sim também escreveram comentários: o Caio: "Gostei de quão longe a imaginação do eu-lírico chega, e do fato de aparentar que ele, finalmente, ao final, se sente bem consigo mesmo. O que me incomodou um pouco, porém, foi a falta de transição entre algumas passagens"; a Júlia: "Gostei principalmente do jeito que está escrito, faz com que você participe do livro"; e o Tobias: "Gostei da história, só não achei que ela tem um começo, meio e fim".

No primeiro grupo de ex-alunos formados por outras pedagogias, quatro participantes assinalaram gostei muito (Cibele, Guilherme, Igor e Mateus). O Igor escreveu "Fofo" e o Mateus comentou que "Ilustra a vida de muitas crianças, uma bela história". Dos quatro alunos que assinalaram sim, apenas a Raquel comentou 
que "Além do livro brincar com as palavras e imagens, passa para o leitor a importância da vida". No segundo grupo, seis alunos assinalaram gostei muito (Drieli, Elaine, Marcos, Sarah, Talita e Val). Três deles comentaram o motivo de terem gostado muito: a Drieli: "Gostei muito da estória, me fez interagir com a mesma"; a Elaine: "Gostei muito do texto, mostra a importância de um amigo" e a Talita: "Ela faz com que você se divirta lendo este livro". Dois dos três participantes que assinalaram sim (Paloma, Pedro e Sidney) escreveram comentários: a Paloma: "Livro bom, mas indicado para criancinhas. RS! Alguns trechos começa com rimas, muito engraçadinho" e o Sidney: "Poema bom teve criatividade nos pontos do poema”.

Em relação à ilustração, no grupo de ex-alunos Waldorf, dois assinalaram mais ou menos (Daniel e Tobias), dois assinalaram sim (Caio e Caroline) e os outros cinco assinalara que gostaram muito. O Gabriel escreveu "Ilustração criativa". No primeiro grupo de não-Waldorf, o Gabriel assinalou mais ou menos, três participantes assinalaram sim (Daniele, Igor e Nathalia 1) e, os outros cinco, assinalaram gostei muito. No segundo grupo de não-Waldorf, o Sidney assinalou mais ou menos, o Pedro assinalou sim e sete assinalaram gostei muito.

A Raposa e o Cavalo e O Príncipe Cavalinho são narrativas primordiais, que de acordo com Rudolf Steiner, são portadoras da história espiritual da humanidade e remetem ao $\mathrm{Eu}$ (ou corpo anímico-espiritual). Ao mesmo tempo, o fato dos animais serem os protagonistas da estória em $A$ Raposa e o Cavalo, como já foi dito, ajuda a incorporar o corpo astral (ou corpo das sensações) que é o que o homem tem em comum com os animais. No conto O Príncipe Cavalinho temos as imagens religiosas, a providência divina e a metamorfose do cavalo em príncipe, que ajudam 
na integralização do corpo éterico.

No grupo de ex-alunos Waldorf, o Gabriel foi o único a assinalar que não gostou do conto A Raposa e o Cavalo; quatro participantes assinalaram mais ou menos (Caio, Clara, Júlia e Sofia 1). O Caio escreveu: "Me agradou o estilo textual, porém, como é um texto infantil, a ideia de 'jeito mais fácil' pode ser transmitida à criança"; a Clara: "Acho que não entendi a moral da história"; a Sofia 1: "Essas pequenas histórias, principalmente com finais 'abruptos' não me agradam muito. Apesar disso, é muito bem conduzida" e a Júlia 1 não fez nenhum comentário. A Caroline e o Tobias assinaram sim sem tecer nenhum comentário. O Daniel e a Carol assinalaram que gostaram muito, sendo que apenas a Carol escreveu que "A simplicidade com que se trata o tema é muito interessante".

No primeiro grupo de ex-alunos formados por outras pedagogias, a Cibele, o Igor e a Nathalia 1 assinalaram mais ou menos e o Igor comentou que "Esperava um final melhor". Três participantes assinalaram sim (Daniele, Guilherme e Raquel) e gostei muito (Gabriel, Lizandra e Mateus). No segundo grupo, quatro alunos assinalaram mais ou menos (Elaine, Marcos, Talita e Val), quatro assinalaram sim (Drielli, Pedro, Sarah e Sidney). A Paloma assinalou que gostou muito e escreveu: "Grande lição de moral. No início pensei que a raposa ia trair o cavalo, mas na verdade foi uma grande e verdadeira amizade". A Talita comentou que "Esperava um final mais agitado, emocionante e interessante".

O resultado da apreciação da leitura do conto O Príncipe Cavalinho entre os ex-alunos Waldorf foi: um participante assinalou que não gostou (Caio), três assinalaram mais ou menos (Carol, Gabriel e Sofia 1) e os cinco restantes assinalaram sim. Dois participantes fizeram comentários: o Caio ("Me incomodou o 
fato de que as filhas do rei continuaram a se apaixonar pelo príncipe, apesar da injúria da pata. Não gostei, também, que tudo o que o príncipe queria, era ser reconhecido como homem") e a Júlia ("Apesar de ser um conto, poderia ser mais elaborado"). No primeiro grupo de participantes não-Waldorf, três assinalaram mais ou menos (Daniele, Gabriel e Mateus), três assinalaram sim (Cibele, Igor e Raquel) e três assinalaram que gostaram muito. A Lizandra escreveu "Muito linda esta estória" e a Raquel "Com esse conto pode-se perceber que existe uma coisa chamada destino". No segundo grupo de não-Waldorf, o Sidney assinalou que não gostou e escreveu "A história não faz muito sentido". O Pedro assinalou mais ou menos, a Talita assinalou sim e os outros seis participantes assinalaram que gostaram muito. A Elaine achou o conto "muito criativo e engraçado"; o Marcos escreveu "Um conto maravilhoso"; e, a Paloma, "Muito engraçado".

É com a obra $O$ Beijo da Palavrinha que será feita a ligação entre o corpo etérico e o corpo físico, como explicado no capítulo quatro desta tese.

No grupo dos ex-alunos Waldorf, a estória $O$ Beijo da Palavrinha foi considerada mais ou menos por três participantes (Clara, Daniel e Gabriel), o Caio assinalou sim e os outros cinco participantes assinalaram gostei muito. Apenas três participantes fizeram comentários: o Caio ("O que mais me chamou a atenção foi a crença de que o mar cura; como antigamente, o mar se tornou sinônimo de esperança"), a Júlia ("Gosto muito de Mia Couto e a ilustração é maravilhosa") e a Sofia ("Mia Couto tem o dom de nos levar por suas palavras. A ilustração vem da leitura, e foi enfeitada pelos desenhos no papel").

No primeiro grupo não-Waldorf a Daniele não gostou da estória, o Mateus mais ou menos, três participantes assinalaram sim (Cibele, Gabriel e Nathalia 1) e os 
outros quatro participantes assinalaram que gostaram muito. Dois participantes escreveram comentários: a Daniele (“Achei que a ilustração não tem uma ligação com o texto") e a Raquel ("Tudo depende de como enxergamos as coisas, mas não o 'enxergar' com os olhos, mas sim com a alma..."). No segundo grupo não-Waldorf, a Talita não gostou da estória, três assinalaram mais ou menos (Paloma, Pedro e Sidney), três assinalaram sim (Drieli, Elaine e Val) e os outros dois assinalaram que gostaram muito. Foram feitos três comentários: "A estória prende a atenção, e deixa sempre um ar de curiosidade, porém não gostei tanto da estória pelo fato do final da mesma não ter sido como eu esperava" (Drieli); "No começo da estória você se da conta das imagens bonitas e interessantes após a leitura você viaja literalmente com o interesse de saber o final da história" (Marcos) e "Apesar de ter gostado da ilustração, não acho que esteja de acordo com o texto".

A ilustração do livro O Beijo da Palavrinha foi considerada mais ou menos por três ex-Waldorf (Daniel, Gabriel e Tobias), sim foi assinalado pelo Caio e os outros cinco participantes assinalaram que gostaram muito. No primeiro grupo não-Waldorf, a Daniele e o Mateus assinalaram que não gostaram da ilustração, a Cibele assinalou mais ou menos, três participantes assinalaram sim (Gabriel, Igor e Lizandra) e os outros três participantes assinalaram que gostaram muito. No segundo grupo não-Waldorf, a Paloma e o Sidney não gostaram da ilustração, a Elaine e o Pedro assinalaram mais ou menos, quatro participantes assinalaram sim (Drieli, Marcos, Talita e Val) e apenas a Sarah assinalou que gostou muito.

Mia Couto já era conhecido pelos ex-alunos Waldorf, mas não era conhecido por nenhum dos grupos formados por outras pedagogias.

A obra A Moça Tecelã, como dissemos anteriormente, simboliza o corpo físico 
e possibilita a integração deste corpo com os quatro corpos constitutivos propostos por Steiner.

A estória $A$ Moça Tecelã foi considerada mais ou menos por dois ex-alunos Waldorf (Daniel e Gabriel), Tobias assinalou sim e todos os demais gostaram muito. O Caio escreveu "Gostei muito que a mulher preferiu uma vida simples a uma vida de ganância"; a Carol: "A estória além de fazer parte do meu repertório infantil é uma elaboração que até hoje me encanta"; a Clara: "Achei a ilustração genial, super trabalhada e bem feita"; a Júlia: "O mais lindo! E as ilustrações de bordados são espetaculares"; a Sofia: "Incríveis, tanto história quanto ilustração". O único que não gostou da ilustração foi o Gabriel e o Daniel achou mais ou menos. Três participantes assinalaram sim para a ilustração (Caio, Caroline e Tobias) os outros quatro participantes gostaram muito da ilustração.

No primeiro grupo de ex-alunos formados por outras pedagogias, a Daniele e o Igor consideraram a estória mais ou menos, três participantes assinalaram sim (Cibele, Gabriel e Nathalia 1) e os outros quatro gostaram muito da estória. A Daniele e o Mateus acharam a ilustração mais ou menos, cinco participantes assinalaram sim e dois assinalaram que gostaram muito (Guilherme e Lizandra). Nenhum aluno deste grupo fez comentários.

No segundo grupo de ex-alunos formados por outras pedagogias, o Pedro achou a estória e a ilustração mais ou menos, a Elaine e a Talita assinalaram sim para a estória e para a ilustração e os outros seis participantes gostaram muito da estória e da ilustração. O único que escreveu comentário foi o Sidney: "Poema espetacular mostra que simples coisas pode fazer uma pessoa feliz".

Ao serem questionados sobre as estórias que os fizeram se sentir parte 
integrante, todos os ex-alunos Waldorf escolheram pelo menos uma delas. O Daniel escolheu O Príncipe Cavalinho, o Gabriel o poema Vocês Acreditam? As respostas do Caio e do Tobias coincidiram; eles assinalaram três estórias: $A$ Raposa e 0 Cavalo, O Príncipe Cavalinho e A Moça Tecelã. A Caroline escolheu Vi uma Estrela lá Fora, O Beijo da Palavrinha e A Moça Tecelã. As quatro estórias escolhidas pela Carol, pela Júlia e pela Sofia 1 foram: o poema Vocês Acreditam?, Vi uma Estrela lá Fora, O Beijo da Palavrinha e A Moça Tecelã. A Clara escolheu as mesmas quatro e mais uma, O Príncipe Cavalinho.

Enquanto no grupo de ex-Waldorf alguns participantes assinalaram até cinco estórias, no primeiro grupo não-Waldorf os alunos foram mais reticentes em relação a sentirem-se parte integrante. Quatro deles assinalaram apenas uma estória: a Cibele (Pobre Vovô!), o Guilherme e a Nathalia 1 (Vi uma Estrela lá Fora) e o Igor (O Beijo da Palavrinha). Três participantes assinalaram duas obras: o Gabriel (o poema Vocês Acreditam? e A Raposa e o Cavalo), a Lizandra (O Príncipe Cavalinho e $A$ Moça Tecelã) e a Raquel (o poema Pobre Vovô! e Vi uma Estrela lá Fora), sendo que apenas Vi uma Estrela lá Fora foi a escolha comum. A Danielle assinalou o poema Vocês Acreditam?, Vi uma Estrela lá Fora e A Raposa e o Cavalo. O Mateus assinalou o poema Pobre Vovô!, A Raposa e o Cavalo e A Moça Tecelã.

No segundo grupo não-Waldorf, a Talita não se sentiu parte integrante de nenhuma das estórias propostas. A Elaine assinalou apenas o poema Vocês Acreditam?. Três participantes assinalaram duas obras distintas: o Pedro (o poema Vocês Acreditam? e Vi uma Estrela lá Fora), a Sarah (o poema Vocês Acreditam? e O Príncipe Cavalinho) e o Sidney (Vi uma Estrela lá Fora e A Moça Tecelã). O Marcos assinalou três obras ( Vi uma Estrela lá Fora, O Príncipe Cavalinho e O Beijo 
da Palavrinha) e os demais alunos escolheram quatro obras cada: a Drieli (os dois poemas Pobre Vovô! e Vocês Acreditam?, Vi uma Estrela lá Fora e A Moça Tecelã), a Paloma (os dois poemas e os contos A Raposa e o Cavalo e O Príncipe Cavalinho) e a Val (Vi uma Estrela lá Fora, O Príncipe Cavalinho, o Beijo da Palavrinha e A Moça Tecelã).

$\mathrm{Na}$ questão catorze, os participantes deveriam assinalar a(s) estória(s) que preferia $(m)$ não ter lido. Desta forma, saberíamos se havia alguma semelhança entre as respostas dadas pelos participantes em geral e entre os grupos em particular. Cinco participantes do grupo formado pela pedagogia Waldorf manifestaram-se. $\mathrm{O}$ Caio e a Júlia assinalaram duas estórias, sendo que suas opiniões não coincidiram, já que o Caio preferia não ter lido Vi uma Estrela lá Fora e O Príncipe Cavalinho enquanto a Júlia preferia não ter lido o poema Pobre Vovô! e o conto A Raposa e o Cavalo. Os outros três participantes assinalaram apenas uma estória, sendo que o Gabriel e a Sofia preferiam não ter lido o conto dos Irmãos Grimm e a Carol preferia não ter lido O Príncipe Cavalinho.

No primeiro grupo não-Waldorf, a Daniele preferia não ter lido $O$ Beijo da Palavrinha e A Moça Tecelã; o Gabriel e o Mateus assinalaram apenas O Beijo da Palavrinha; a Nathalia 1 assinalou $A$ Raposa e o Cavalo; o Igor preferia não ter lido $A$ Raposa e o Cavalo e O Príncipe Cavalinho. No segundo grupo não-Waldorf, sete participantes se manifestaram, sendo que três deles assinalaram apenas o conto $A$ Raposa e o Cavalo (Elaine, Marcos e Sarah); a Paloma assinalou A Moça Tecelã; o Pedro assinalou $O$ Beijo da Palavrinha e A Moça Tecelã; a Talita assinalou $O$ Príncipe Cavalinho e A Moça Tecelã. O Sidney foi o mais insatisfeito de todos os participantes da pesquisa assinalando quatro obras: os dois poemas, O Príncipe 
Cavalinho e A Moça Tecelã.

Não foi possível estabelecer um padrão. Houve diversidade de gosto entre os participantes em geral, independente do grupo ao qual pertenciam. Ao mesmo tempo, pelas respostas dadas, já era possível prever que os participantes haviam se identificado com alguma ou algumas das estórias propostas. E foi exatamente isso que aferimos na décima quinta questão: "Assinale a(s) estória(s) que você gostaria de ter em sua biblioteca particular".

No grupo de ex-alunos Waldorf foram assinaladas de uma a quatro obras. Entre os participantes que assinalaram apenas uma estão o Caio ( $A$ Moça Tecelã), o Gabriel (o poema Vocês Acreditam?) e o Tobias (O Príncipe Cavalinho), sem que houvesse concordância nas obras escolhidas. Três participantes assinalaram duas obras: a Júlia e a Sofia (O Beijo da Palavrinha e A Moça Tecelã) e o Daniel (o poema Vocês Acreditam? e O Príncipe Cavalinho). A Clara selecionou três obras (Vi uma Estrela lá Fora, O Beijo da Palavrinha e A Moça Tecelã). A Carol e a Caroline assinalaram quatro das obras propostas, sendo três coincidentes (o poema Vocês Acreditam?, O Beijo da Palavrinha e $A$ Moça Tecelã) e, a quarta, para a Carol, foi $A$ Raposa e o Cavalo e, para a Caroline, Vi uma Estrela lá Fora. Nenhum ex-Waldorf gostaria de ter o poema Pobre Vovô! em sua biblioteca particular.

No primeiro grupo não-Waldorf, os participantes assinalaram de duas a cinco obras. A Cibele assinalou o poema Vocês Acreditam? e Vi uma Estrela lá Fora, que também foram assinaladas pela Daniele, que assinalou também os contos $A$ Raposa e o Cavalo e O Príncipe Cavalinho. O Daniel gostaria de ter em sua biblioteca particular o poema Vocês Acreditam? e o conto A Raposa e o Cavalo, que foram as opções do Mateus, sendo que ele ainda assinalou mais três obras: o poema Pobre 
Vovô!, Vi uma Estrela lá Fora e A Moça Tecelã. O Guilherme assinalou o poema Vocês Acreditam?, O Beijo da Palavrinha e A Moça Tecelã. O Igor escolheu o poema Pobre Vovô!, O Beijo da Palavrinha e A Moça Tecelã. A Lizandra só não assinalou os dois poemas. A Nathalia 1 escolheu o poema Vocês Acreditam?, Vi uma Estrela lá Fora e O Príncipe Cavalinho. A Raquel escolheu o poema Pobre Vovô!, Vi uma Estrela lá Fora, O Príncipe Cavalinho e A Moça Tecelã.

No segundo grupo não-Waldorf, as escolhas variaram de uma a cinco obras. Entre os participantes que escolheram apenas uma única obra, temos a Elaine $(O$ Príncipe Cavalinho) e o Pedro (Vi uma Estrela lá Fora). Dois participantes assinalaram duas obras, o Sidney e a Talita, sendo A Moça Tecelã em comum e Vi uma Estrela lá Fora escolhida pelo Sidney e O Príncipe Cavalinho pela Talita. A Paloma assinalou três obras: os dois poemas e o conto A Raposa e o Cavalo. $O$ Marcos e a Val assinalaram as mesmas quatro obras: Vi uma Estrela lá Fora, 0 Príncipe Cavalinho, O Beijo da Palavrinha e A Moça Tecelã. A Drieli e a Sarah escolheram cinco obras; três coincidiram (o poema Vocês Acreditam?, Vi uma Estrela lá Fora e A Moça Tecelã). A Drieli complementou sua escolha com o poema Pobre Vovô! e o conto dos Irmãos Grimm, enquanto a Sarah completou com 0 Príncipe Cavalinho e O Beijo da Palavrinha.

$\mathrm{Na}$ décima sexta questão, os participantes deveriam assinalar a(s) estória(s) que indicaria $(\mathrm{m})$ como leitura indispensável às pessoas que amam. Com exceção de três participantes formados pela pedagogia Waldorf (Daniel, Gabriel e Tobias), todos os demais, de todos os grupos pesquisados, assinalaram pelo menos uma obra. Consideramos este fato interessante, visto que o Caio, o Daniel e o Tobias escolheram uma ou duas obras para terem em sua biblioteca particular, como já 
citado. Significa que as obras não são indispensáveis aos outros, mas tiveram um significado pessoal.

Foi justamente as respostas destes três participantes que nos levaram a apurar as respostas dos participantes em geral, contrapondo-as às respostas dadas à questão anterior. Verificamos que no caso dos ex-alunos Waldorf, o Caio, a Caroline e a Sofia indicariam as mesmas obras que gostariam de ter em sua biblioteca particular, enquanto que a Carol, a Clara e a Júlia não. A Carol teria em sua biblioteca o poema Vocês Acreditam?, A Raposa e o Cavalo, O Beijo da Palavrinha e $A$ Moça Tecelã, destas quatro obras, indicaria três, não indicando a $A$ Raposa e o Cavalo, mas indicaria também Vi uma Estrela lá Fora que não foi selecionada para sua biblioteca particular. A Clara teria em sua biblioteca Vi uma Estrela lá Fora, O Beijo da Palavrinha e A Moça Tecelã, considerou duas delas indispensáveis para seus entes queridos, não assinalando $A$ Moça Tecelã como indispensável. E a Júlia, que havia escolhido O Beijo da Palavrinha e A Moça Tecelã, só indicaria A Moça Tecelã.

No primeiro grupo de ex-alunos de outras pedagogias, os únicos que indicariam as mesmas obras escolhidas para sua biblioteca particular foram o Mateus e a Raquel. A Cibele teria em sua biblioteca o poema Vocês Acreditam? e Vi uma Estrela lá Fora, mas indicaria duas obras distintas: O Beijo da Palavrinha e $A$ Moça Tecelã. A Daniele não indicaria nenhuma das quatro obras que ela escolheu para ter em sua biblioteca, mas indicaria $O$ Beijo da Palavrinha. O Gabriel, que escolheu o poema Vocês Acreditam? e conto dos Irmãos Grimm, só indicaria o poema aos seus entes queridos. O Guilherme, que escolheu o poema Vocês Acreditam?, O Beijo da Palavrinha e A Moça Tecelã, não indicaria o poema, mas 
manteria as outras duas obras. O Igor gostaria de ter em sua biblioteca o poema Pobre Vovô!, O Beijo da Palavrinha e A Moça Tecelã, sendo que manteria as duas primeiras indicações, mas não indicaria A Moça Tecelã. A Nathalia 1 teria o poema Vocês Acreditam?, Vi uma Estrela lá Fora e O Príncipe Cavalinho e só não indicaria o poema. E a Lizandra, que havia escolhido cinco obras para sua biblioteca particular, assinalou que indicaria todas as obras como leituras indispensáveis às pessoas que ela ama, incluindo, desta forma, os poemas que ela não quis em sua biblioteca particular.

No segundo grupo de ex-alunos formados por outras pedagogias, o Marcos, a Paloma, o Pedro e o Sidney indicariam as mesmas obras que escolheram para terem em suas bibliotecas particulares. A Drieli só indicaria três das cinco obras que teria em sua biblioteca: Vi uma Estrela lá Fora, O Beijo da Palavrinha e A Moça Tecelã. A Sarah, que escolheu cinco obras para ter em sua biblioteca, indicaria quatro delas, não indicando $O$ Beijo da Palavrinha. A Elaine indicaria uma obra diferente da que escolheu para si; ela escolheu O Príncipe Cavalinho e indicaria o poema Vocês Acreditam? A Talita escolheu duas obras para ter em casa, mas não indicaria estas duas; indicaria Vi uma Estrela lá Fora. A Moça Tecelã. A Val indicaria as quatro obras escolhidas por ela e acrescentaria também os dois poemas.

A penúltima questão do questionário da experiência estética de leitura pedia aos participantes que assinalassem a(s) estória(s) que o fizeram repensar nas frases utilizadas para definir a velhice, a morte e a vida no primeiro questionário. Apenas quatro ex-alunos Waldorf assinalaram alguma obra: a Carol (o poema Vocês Acreditam? e A Moça Tecelã), a Caroline (Vi uma Estrela lá Fora, O beijo da Palavrinha e A Moça Tecelã), a Júlia (o poema Pobre Vovô!) e a Sofia (Vi uma 
Estrela lá Fora e O Beijo da Palavrinha).

Todos os participantes do primeiro grupo não-Waldorf assinalaram alguma obra: a Cibele assinalou os dois poemas e O Beijo da Palavrinha; a Daniele e o Gabriel assinalaram o poema Pobre Vovô!; o Guilherme marcou Vi uma Estrela lá Fora e A Moça Tecelã; o Igor os dois poemas, O Beijo da Palavrinha e A Moça Tecelã; a Lizandra O Príncipe Cavalinho, O Beijo da Palavrinha e A Moça Tecelã; o Mateus os dois poemas e Vi uma Estrela lá Fora; a Nathalia O Beijo da Palavrinha e A Moça Tecelã; e, a Raquel, o poema Pobre Vovô!, Vi uma Estrela lá Fora e A Moça Tecelã. Nenhum aluno do primeiro grupo assinalou A Raposa e o Cavalo.

Apenas a Elaine, do segundo grupo não-Waldorf, não assinalou nenhuma obra. A Drieli assinalou o poema Pobre Vovô!, O Beijo da Palavrinha e A Moça Tecelã. O Marcos e a Val assinalaram O Príncipe Cavalinho, O Beijo da Palavrinha e A Moça Tecelã. A Paloma assinalou os dois poemas e A Raposa e o Cavalo. O Pedro assinalou o poema Pobre Vovô! e o conto A Raposa e o Cavalo. A Sarah marcou os dois poemas e A Moça Tecelã. O Sidney assinalou Vi uma Estrela lá Fora e a Talita o poema Pobre Vovô!, O Príncipe Cavalinho e O Beijo da Palavrinha.

A grande diferença entre participantes formados pela pedagogia Waldorf e os participantes formados por outras pedagogias ocorreu nas respostas dadas à última pergunta do questionário da experiência estética de recepção de leitura: "Dê sua opinião sincera do que representou para você participar desta pesquisa". É importante salientar que, antes que os participantes respondessem a questão, o entrevistador explicou que eles deveriam ser o mais sincero possível, inclusive sinalizando se a atividade foi chata, entediante ou qualquer outro desconforto que tivessem experimentado durante a experiência estética de recepção de leitura. 
A grande maioria dos participantes Waldorf interpretou a pergunta em relação à tese como um todo e não em relação à experiência de leitura literária proposta. Acreditamos que isto se deve ao fato de que durante doze anos, ou menos, para os três alunos que ingressaram tardiamente na Escola Waldorf Rudolf Steiner de São Paulo, aprenderam ouvindo e lendo estórias, recitando poemas, como parte integrante e fundamental do currículo. Portanto, a pergunta não fez muito sentido para eles. Além disso, a motivação que os levou a aceitar participar da pesquisa também foi diferente, visto que o que os empolgou foi a possibilidade de promoverem a pedagogia e não a possibilidade de ler estórias infantis.

De qualquer forma, descartamos a possibilidade da pergunta não ter sido bem formulada, por meio das respostas dadas por quatro participantes Waldorf, conforme as citações abaixo:

"A pesquisa feita com os ex-alunos Waldorfs me deixou extremamente empolgada pelo fato de saber de algo concreto, como uma pesquisa, focado na pedagogia que regeu a minha vida. Ler estórias me fez voltar no tempo e poder refletir sobre elas com mais maturidade e consciência, podendo captar a sensibilidade que cobre de fantasia as estórias que se encaixam na realidade humana". (Carol)

"Acho que foi uma forma de relembrar experiências passadas na escola, apesar de não gostar muito desta escola ela me deixou bons amigos e boas lembranças. Em questão aos poemas, acho que não tenho a mente capaz de ver por de trás do que os autores escrevem, portanto muitas vezes minha opinião sobre isso não é positiva". (Gabriel)

"Não sei muito o que falar sobre a pesquisa... Acho que seria bacana fazer mais coisas, uma pesquisa um pouco mais extensa. Mas achei 
interessante os temas abordados e os livros/contos/poemas escolhidos. Quero ver o resultado, fiquei bastante curiosa (e até queria fazer mais!). Achei muito bacana a pesquisa envolver a pedagogia Waldorf de modo tão positivo (nessa questão da leitura), fico muito feliz de ver o conhecimento sobre e dentro dessa pedagogia tão incrível se alastrando". (Sofia 1)

"Gostei de participar da pesquisa porque ajudei a contribuir na conclusão do Mestrado. Gostei das histórias que li, achei muito interessantes e me trouxeram lembranças de quando eu era criança". (Tobias)

As demais respostas dos ex-alunos Waldorf foram:

"Fico feliz em poder dar minha opinião livremente. Apesar de não haver sido aluno Waldorf por muito tempo, tive certa influência". (Caio)

"Participar desta pesquisa trouxe uma grande satisfação em conhecer a pedagogia Waldorf e ainda mais ter sido aluna e me formar na Rudolf Steiner. Isso mostra como a nossa pedagogia esta se tornando cada vez mais popular e abrindo olhos e cabeças de pessoas que se propõem a entender a maneira Waldorf de ver 0 mundo. Sinto-me muito grata de poder contribuir para que a pedagogia Waldorf seja conhecida sempre por mais pessoas". (Caroline)

"Sinceramente, não sei. Acho que saberei melhor no final, quando a pesquisa estiver finalizada. Sinto a necessidade da conclusão da pesquisa para ter minha conclusão do que ela representou para mim". (Clara)

"Foi muito interessante, pois muitos adoram a pedagogia Waldorf, mas poucos a conhecem muito bem. Então será, talvez, um incentivo para vários a conhecerem". (Daniel)

"Acho a Waldorf a melhor pedagogia e sou muito grata por ter tido a 
oportunidade de vir estudar aqui. Acho importante as pessoas verem a diferença da cabeça de um ex-aluno Waldorf e um ex-aluno de uma escola tradicional. Sou muito feliz comigo mesma em ver a pessoa que eu me tornei depois de mudar para a Waldorf". (Júlia)

Por outro lado, os participantes formados por outras pedagogias, não só entenderam a pergunta como também responderam positivamente quanto a terem participado. Para a maioria foi uma novidade ouvir estórias e ler estórias que eles não conheciam e que, apesar de serem "infantis", tinham muito para ensinar. Isto pode ser verificado não apenas nos dezoito alunos escolhidos (nove do primeiro grupo e nove do segundo grupo), mas nas respostas dos doze que foram descartados também. A motivação destes alunos para participar da pesquisa foi participar de uma experiência de leitura de livros infantis. Todos os trinta alunos responderam que ficaram felizes em participar.

Antes de apresentarmos algumas considerações sobre as duas etapas da pesquisa, consideramos importante apresentar a transcrição literal dos comentários realizados pelos demais participantes.

No primeiro grupo de ex-alunos formados por outras pedagogias, tivemos as seguintes respostas:

"Achei bem bacana, nunca tinha feito uma atividade assim, de dar opinião sobre ilustrações. Me fez lembrar também os meus tempos de escola, bem legal, e alguns poemas até me fez lembrar de coisas pessoais". (Cibele)

"Gostei muito. Achei diferente de tudo aquilo que participei da minha vida escolar. Teve poemas e livros que nunca tinha lido, julguei poemas e livros pela capa ou desenho achando que seria chato e 
depois de lidos mudei minha opinião". (Danielle)

"Uma viagem no tempo de criança, muito legal, me fez relembrar a infância". (Gabriel)

"Me fez recordar que estórias infantis têm muito a acrescentar e que talvez repassar isso para nossos filhos, netos e etc. seja indispensável". (Guilherme)

"O texto 'O Beijo da Palavrinha' me fez sentir vontade de voltar para velhos costumes meus, como ir a praia e sentir a brisa do mar. Somente por esse texto já valeu, e muito, ter vindo em uma noite fria, de uma segunda-feira, para a faculdade". (Igor)

"Foi muito importante essa experiência, gostei de todas as leituras, mas algumas realmente me fizeram relembrar a infância, onde tudo era imaginação, como 'A Moça Tecelã' e 'Vi uma estrela lá fora'”. (Lizandra)

"Teve uma importância muito grande pois nenhuma dessas estórias eu conhecia, foi bem divertido e muitas ou a maioria dessas estórias me fez voltar ao passado e relembrar minha infância". (Mateus)

"Gostei bastante de participar, não conhecia os poemas e me vi em alguns deles. Também pude refletir sobre algumas coisas, pois as vezes a gente julga o que as pessoas fazem mas não nos colocamos no lugar. Foi bem agradável estar aqui e poder ler um pouco algo diferente do normal. O livro que eu mais gostei foi 'Vi uma estrela lá fora', pois é parecido com meu jeito de ser, agir e pensar". (Nathalia 1)

"Acho que a melhor forma de adquirir conhecimento é através da leitura, pode ser um conto infantil, ou um livro acadêmico para nos ajudar na prova, como iremos fazer por alguns semestres. Gostei muito de participar da pesquisa, leituras infantis, além de conhecimento, nos ensina valores, valores como caráter, respeito com o próximo, com nós mesmos, amar a vida". (Raquel) 
No segundo grupo de ex-alunos formados por outras pedagogias, as respostas foram as seguintes:

"Gostei muito de participar da pesquisa, gostei das estórias e dos poemas, e pude com facilidade entender e interpretar os textos. De fato, a participação nesta pesquisa foi muito benéfica para mim, gostei muito, em todos os aspectos. Me fez lembrar da minha infância, quando as professoras liam estórias, me trouxe a mesma sensação de que eu estivesse dentro da estória, fizesse parte dela". (Drieli)

"Sinceramente, participar desta pesquisa, foi muito satisfatório para mim. Relembrar de momentos, alegrias e medos da minha infância, foi muito bom. Agregou meus conhecimentos, afinal, foram estórias e poemas que eu não conhecia". (Elaine)

"Todos os poemas e textos são legais e fácil de entender, alguns mais interessantes outros menos interessantes. O divertido de tudo é que se damos conta de como ler é gostoso, histórias legais e que a pessoa viaja com a imaginação, algo que só tínhamos e faziamos quando criança. 'O príncipe cavalinho', estória em que me diverti em ler. 'O beijo da palavrinha', dá uma ansiedade enorme de saber o final. 'Vi uma estrela lá fora', livro muito legal para se ler ao irmão ou filho". (Marcos)

"Achei muito interessante a pesquisa. Gostei de quase todas as leituras e também das ilustrações. Faria de novo a pesquisa pois é muito boa e nos estimula ainda mais ler esses tipos de histórias ilustradas". (Paloma)

"Representou pensar um pouco mais antes de tomar algumas atitudes, representou também que é bom ler e fazia tempo que eu não lia. Foi bom ler esses textos e poemas". (Pedro)

"Bem, na pesquisa em que fizemos, pude observar mais sobre o mundo 'imaginário' de uma criança, como tudo pode ser um conto, história. A criatividade de pensar além da rotina, criar coisas, textos 
geniais com pequenas coisas, como por exemplo o texto de Regina Chamlian e Helena Alexandrino, eles falam sobre o mundo dentro de um quarto. As histórias são fantásticas e criativas, para mim foi exitante participar da pesquisa, e me deu a possibilidade de ter vontade de ler cada vez mais livros". (Sarah)

"A pesquisa levei como uma grande oportunidade de refletir porque não damos valor e esquecemos de coisas simples porém importantes em nossas vidas. Uma oportunidade pra mim de avaliar meu conhecimento que foi adquirido e aplicar em minha vida. O livro 'A moça tecelã' foi o melhor livro que já li, mostra pra gente uma realidade que até acontece é fantástico fiquei envolvido na história do começo ao fim. Participar desta pesquisa foi uma honra todos estão de parabéns". (Sidney)

"Gostei de ter participado da leitura e me expressar sobre minha opinião das mesmas. Mas não sei se teria me acrescentado algo, ou melhor, reparei que devo praticar mais a leitura para próprio benefício". (Talita)

"Gostei muito de participar da pesquisa. Foi muito interessante conhecer novas estórias e novos autores. Teve estórias divertidas e outras que me fizeram repensar sobre minha vida e sobre minhas ações. Gostei de participar e espero ter outras oportunidades de participar de outros encontros como esse". (Val)

Os resultados obtidos também foram comprovados entre os doze alunos descartados. Optamos por apresentar suas respostas em relação à última questão para comprovar esta afirmação. Acrescentado, na frente do nome do participante, o ano de nascimento, visto que quatro eram mais velhos, conforme explicado anteriormente. As respostas, do participante mais novo para o mais velho, foram:

"Adorei as estórias, todas tem algum significado muito importante para mim. Cada uma me proporcionou maneiras diferentes de ver a vida; gosto muito de ler, então esse momento me deu grande prazer 
de participar da pesquisa, e também indico esses livros para todos lerem". (Elizabete, 1996)

"Me fez apegar-se mais a leitura, gosto muito de ler, ainda mais quando me identifico com a leitura, principalmente daquelas que são mais antigas". (Daphine, 1996)

"Foi uma ótima experiência pois a leitura amplia nosso olhar e nos ajuda a reviver a imaginação e muitos sonhos que tínhamos em nossa infância. Gostei muito". (Larissa, 1996)

"Uma pesquisa interessante, me identifiquei bastante com alguns livros, seria interessante ler para minha irmãzinha que tem apenas 2 anos e pedir para que ela leia quando crescer, porque a cada vez que ela ler esses livros vai tirar uma nova conclusão pela sua experiência de vida. O que mais se parece comigo é 'Vi uma estrela lá fora'”. (Amanda 2, 1995)

"Essa pesquisa relacionada a leitura mostrou uma realidade de tal situação na vida, de como podemos tirar como uma certa reflexão para nós, e mostrou que a leitura é algo muito bom fazendo com que entedemos de alguma forma a leitura. Os poemas e as estórias mostrou em cada um uma realidade ou acontecimento totalmente diferente, tornando assim com que entendesse de modo totalmente diferente. Bom, eu achei super interessante ter essa pesquisa, pois entendi alguns livros e poemas, eu normalmente não tenho uma tal paciência em ter interesse de ler, mas hoje consegui tirar alguma coisa das leituras". (João, 1995)

"As estórias tem um auto nível de cultura em minha percepção e um sentido de ensinamento que nos faz valorizar os detalhes. Gostei muito da estória 'O beijo da palavrinha' sem dúvida nos faz refletir que podemos levar a alegria até mesmo em quem pensamos que nunca mais irá sorrir. E a estória “Vocês acreditam?" me fez ir à uma viagem até minha infância, com superstições que minha vó dizia, hoje vejo graça! A pesquisa foi ótima com certeza só aumentou minha paixão por livros e pela leitura poética. Muito obrigada!". (Lilian, 1995) 
"Em minha opinião, foi bom estar presente nesta pesquisa, pois gostei muito e deu para pensar um pouco na vida, na morte, na velhice, com essas estórias e poemas. Muito bom, apesar de não ter me identificado com uma estória". (Thalles, 1995)

"Sobre a atividade proposta pela professora Kuka, achei maravilhosa. Leitura é algo muito gostoso, e que deveria ser praticado por todos, com frequência, porém, de forma agradável, e não como uma obrigação. Eu gosto de praticar a leitura. Entendo que, por meio desses livros e poemas, eu devo aproveitar cada minuto que a vida me proporciona. Devo ter alguém para passar os dias mais felizes da minha vida ao meu lado. Devo fazer o que tenho vontade, para na velhice, não me lamentar de algo que não fiz. Sobre as pessoas que se aproveitam da nossa boa vontade, não devemos desejar o mau, e sim, que a vida não deve ser vista dessa forma tão dura, porque a vida é linda e intensa. É importante que a gente encontre o amor, porque com ele, iremos preencher o vazio que existe dentro de todos nós. Tudo é importante, e deve ser aproveitado". (Bruna, 1994)

"Representou algo diferente e ao mesmo tempo importante como podemos ter várias opiniões ao mesmo tempo. E o mais importante representou voltar para a infância relembrar as histórias, os momentos que passei quando era criança. Fiquei muito feliz pois vivi momentos maravilhosos e por lembrar dessa forma é muito gratificante". (Gabriela, 1990)

"Muito bom! Me ajudou a repensar várias coisas em minha vida e relembrar várias situações boas e ruins". (Nathalia, 1990)

"Em primeiro lugar, sou sincera em dizer que não gostei muito da ideia no início, mas hoje fazendo a leitura das histórias e que gostei de praticamente todas, gostaria até mesmo de lê-las para meus irmãos pequenos que assim como eu adoram ler, já eu normalmente leio livros de ficção científica e livros que falam sobre a vida e nosso espírito. Gostei muito das histórias lidas hoje e vou procurá-las no google". (Priscila, 1988)

"Adorei ter participado pois fortaleceu alguns pensamentos e a dar 
mais valor a outros. São histórias antigas mais ao mesmo tempo muito atuais, se todos lessem essas histórias dariam mais valor ao sentido da vida". (Cristiano, 1987)

Embora o Thalles tenha mencionado que não se identificou com nenhuma estória, na questão em que os participantes deveriam escolher as obras que gostariam de ter em sua biblioteca ele assinalou o poema Vocês Acreditam? e o livro Vi uma Estrela lá fora. Além disso, ele considerou a leitura do livro Vi uma Estrela lá fora indispensável às pessoas que ele ama. Porém, ele não gostaria de ter lido o poema Pobre Vovô! nem a obra O Beijo da Palavrinha.

\subsection{ALGUMAS CONSIDERAÇÕES SOBRE OS RESULTADOS OBTIDOS}

Os resultados obtidos por meio da aplicação do questionário um, podem ser melhor compreendidos por meio de duas citações de Edgar Morin:

A diversidade das culturas, a diversidade dos indivíduos entre eles e a diversidade interior dos indivíduos não podem ser compreendidas nem a partir de um princípio simples de unidade nem a partir de uma plasticidade mole, modelada pelas culturas ao sabor das circunstâncias. A unidade humana não pode reduzir-se a um termo, a um critério, a uma determinação (nem somente genética, cerebral, mental, cultural) (MORIN, 2007:66).

Cada um contém a multiplicidade e inúmeras potencialidades mesmo permanecendo um indivíduo sujeito único. (MORIN, 2007:95).

Somos diferentes, mesmo estudando em uma mesma escola que adota uma determinada pedagogia. A pedagogia é responsável por uma parte de nossa 
constituição pessoal, mas somos influenciados pela família, pelos amigos, pela sociedade, pela cultura, pelo meio em que vivemos. Além disso, herdamos características de nossos antepassados. Nas palavras de Morin:

A diversidade psicológica ainda é mais surpreendente que a física. Personalidades, caracteres, temperamentos, sensibilidades, humores são de uma variedade inacreditável. Os princípios de inteligibilidade, os sistemas de ideias são extremamente diversos de cultura para cultura e mesmo dentro de uma mesma cultura. Conforme as culturas, conforme os indivíduos, as repartições e as combinações entre o pensamento racional/empírico/técnico e o pensamento simbólico/analógico/mágico também são extremamente diversificadas, ao que se acrescenta a diversidade das formas de inteligência, de compreensão e de incompreensão, assim como a diversidade dos modos de pensamento lógico, analógico, intuitivo (MORIN, 2007:58).

E são justamente as combinações entre 0 pensamento racional/empírico/técnico e o pensamento simbólico/analógico/mágico que, de acordo com Steiner, diferenciam um homem dos demais. Ele não utiliza os mesmos termos utilizados por Edgar Morin, mas afirma que há uma universalidade no pensar, "o mundo das ideias que está em meu íntimo é o mesmo que vive nos demais homens" (STEINER, 1979:130) e o que diferencia um homem dos demais é a forma como as ideias resplandecem em cada homem em particular. Há uma citação, que ele faz em relação à criança, que ajuda a compreender melhor suas afirmações. Ele diz que:

A criança, que ainda carece de experiências no que se refere às distâncias, tenta tocar a lua, e retifica o que a primeira vista lhe 
parece verdadeiro somente quando encontra uma outra percepção que contraria a primeira. Toda ampliação do círculo de minhas percepções obriga-me a retificar a imagem que tenho do mundo (STEINER, 1979:52)

Portanto, é a ampliação do círculo das percepções individuais que atualizam e retificam a imagem que a criança tem do mundo e facilitam o conhecimento. E é exatamente neste movimento de afastamento e aproximação entre o que existe fora no mundo e o que existe "dentro", no interior de cada ser, na relação que se estabelece entre o perceber e o pensar, que surgem as representações do mundo, as imagens que formamos do mundo e de nós mesmos.

Realizamos este movimento de afastamento e de aproximação durante toda a vida. Steiner concluiu que são as representações mentais que conferem à vida conceitual uma nota individual, justamente por se relacionarem com os sentimentos individuais de cada ser humano, com as sensações de prazer ou desagrado que as coisas do mundo provocam em cada ser. Morin, como já mencionado, considera que "todo conhecimento, toda percepção, ideal ou teórica, é, ao mesmo tempo, uma tradução e uma reconstrução" (MORIN, 2007:96), portanto, uma representação.

O ensino deve levar em conta o desenvolvimento do intelecto em paralelo com o desenvolvimento da vontade e, para Steiner, o papel desempenhado pela música e pela poesia é fundamental. Ainda, segundo Steiner, como já salientamos, o elemento plástico-pictórico individualiza o ser, o faz entrar em contato com seu mundo interior. No plástico-pictórico contemplamos e vivenciamos a beleza, no poético-musical somos a própria beleza. Para Morin, "a literatura, a poesia e as artes não são apenas meios de expressão, mas também meios de conhecimento" (MORIN, 2007:17). Afirmações válidas para as crianças e também para os adultos 
em geral.

Steiner valorizava o papel da literatura para a formação da vontade por meio de sua atuação no sentir das crianças em desenvolvimento. A experiência estética de recepção de leitura realizada com os participantes da pesquisa visava avaliar a validade de sua proposta para o jovem adulto recém saído do Ensino Médio.

Utilizamos os mesmos critérios estabelecidos por Steiner com relação a não explicar as narrativas, nem procurar saber o que os participantes entenderam das obras. Visávamos propiciar a atuação por inteiro no sentido de desencadear sentimentos e emoções. Lembrando que, para Steiner, as narrativas atuam na criança por inteiro quando desencadeiam sentimentos e emoções, alegria e dor, de forma que a criança sinta em seus membros o que transfere para seu coração e, por último, à cabeça - do sentir ao querer e ao pensar (STEINER, 2003:20-21).

Ao mesmo tempo, ao solicitar que os participantes assinalassem se gostaram ou não das obras, poderíamos verificar o que cada obra representou para cada participante em particular. De acordo com Barthes:

Se aceito julgar um texto segundo o prazer, não posso ser levado a dizer: este é bom, aquele é mal. (...) o texto (o mesmo sucede com a voz que canta) só pode me arrancar esse juízo, de modo algum adjetivo: é isso! E mais ainda: é isso para mim! Este "para mim" não é nem subjetivo, nem existencial, mas nietzchiano ("no fundo, é sempre a mesma questão: O que é que é para mim?"). (BARTHES, 2002:19-20)

O que justifica a diversidade encontrada nas respostas dadas pelos 
participantes.

As diferentes respostas dadas às questões 13 a 17 (estórias que fizeram você se sentir parte integrante, estórias que você preferia não ter lido, estórias que você gostaria de ter em sua biblioteca particular, que seriam leituras indispensáveis às pessoas que você ama e estórias que fizeram você repensar a morte, a velhice e a vida, respectivamente) corroboram este entendimento e demonstram o quanto o prazer é individualizado. Segundo Barthes:

Cada vez que tento "analisar" um texto que me deu prazer, não é minha "subjetividade" que volto a encontrar, mas o meu "indivíduo", o dado que torna meu corpo separado dos outros corpos e lhe apropria seu sofrimento e seu prazer: é o meu corpo de fruição que volto a encontrar. E esse corpo de fruição é também meu sujeito histórico; pois é ao termo de uma combinatória muito delicada de elementos biográficos, históricos, sociológicos, neuróticos (educação, classe social, configuração infantil etc.) que regulo o jogo contraditório do prazer (cultural) e da fruição (incultural), e que me inscrevo como um sujeito atualmente malsituado, vindo demasiado tarde ou demasiado cedo (não designando este demasiado nem um pesar nem uma falta nem um azar, mas apenas convidando a um lugar nulo): sujeito anacrônico, à deriva (BARTHES, 2002:73).

A experiência estética de recepção de leitura realizada com os participantes, durou em média uma hora e dez minutos, tempo relativamente curto. Os resultados obtidos nas respostas dadas à questão "dê sua opinião sincera do que representou para você participar desta pesquisa", assim como nos espaços abertos para comentários dos participantes, revelaram-se bastante significativos.

Como já afirmamos, não houve por parte do pesquisador nenhuma explicação 
sobre as obras, nem exigências sobre a compreensão ou interpretação dos textos, o que fez com que os participantes se sentissem livres para vivenciar os textos, interagir com eles, experimentá-los e comentá-los.

Isto fez com que alguns participantes admitissem, sem culpa, não terem entendido uma estória, como a Clara, ex-aluna Waldorf, que admitiu não ter entendido a moral do conto dos Irmãos Grimm ou o Sidney, do segundo grupo de ex-alunos formados por outras pedagogias, que considerou o poema Pobre Vovô! de difícil entendimento. Embora o significado em ambas as estórias seja de fácil compreensão. Outros foram críticos em relação a falta de transição entre algumas passagens do livro Vi uma Estrela lá fora (Júlia, ex-Waldorf) ou ao fato da estória não ter começo, meio e fim (Tobias, ex-Waldorf).

A Daniele, do primeiro grupo não-Waldorf, falou de suas expectativas em relação à leitura, admitindo ter julgado "poemas e livros pela capa ou desenho achando que seria chato" e depois de lidos mudou de opinião.

Alguns participantes enfatizaram o valor moral veiculado pelas estórias, as lições de vida, os conhecimentos e valores transmitidos pelas narrativas.

De acordo com Leyla Perrone-Moisés:

Entre o dizer e o ouvir, entre o escrever e o ler, ocorrem coisas maiores do que os propósitos de um emissor e as expectativas de um receptor: a um saber inconsciente circulando na linguagem, instituição e bem comum de autores e leitores. O que importa, assim, não são as intenções mensageiras do autor (por melhores que sejam), e sim sua capacidade de imprimir à obra aquele impulso poderoso e aquela abertura estimulante que convide o leitor a prosseguir sua criação (...) Na circulação entre a proposta que é a obra e sua recepção pelo leitor cria-se não propriamente um mundo 
paralelo, representado, e sim uma visão valorativa do mundo em que vivemos (PERRONE-MOISÉS, 1990:109).

A recepção da obra $O$ Beijo da Palavrinha pelo Igor, retrata bem o que foi dito na citação. A morte de Maria Poeirinha não significou para ele tanto quanto o mar retratado na estória, que o fez sentir vontade de voltar a velhos hábitos, como ir à praia e sentir a brisa do mar. E reforça a ideia de Rudolf Steiner da força do sentir no querer e no pensar na constituição dos atos da vontade.

A experiência estética de recepção de leitura fez a Cibele lembrar de coisas pessoais. Ajudou a Nathalia 1 a refletir sobre como é importante nos colocarmos no lugar do outro antes de julgar, além de fazê-la se ver em algumas estórias. Estimulou a Paloma "ainda mais ler esses tipos de histórias ilustradas". Fez o Pedro pensar um pouco mais antes de tomar algumas atitudes e lembrar que "é bom ler e fazia tempo que eu não lia". Deu a Sarah "a possibilidade de ter vontade de ler cada vez mais livros". A Talita reparou que deve "praticar mais a leitura para próprio benefício". Fez a Val querer participar de outras atividades como essa. Impulsionou Priscila a buscar no google as estórias lidas para poder lê-las para seus irmãos. Aumentou a paixão da Lilian pela leitura poética. Fortaleceu alguns pensamentos do Cristiano e o fez dar mais valor a outros.

Sem que houvesse um discurso sobre a importância da leitura literária, vários participantes chegaram a essa conclusão sozinhos, ou melhor, no diálogo estabelecido entre a leitura e o ser de carne e osso que segura o livro em suas mãos. O que reforça a ideia apresentada no capítulo 2, com relação à utilização das narrativas para mudar comportamentos, em lugar de broncas, castigos, lições de moral. Leitura que deve ser silenciosa, no sentido de deixar o texto, e a polifonia das 
vozes presentes em cada texto, dialogar com a consciência de seu receptor, atuando por inteiro no corpo, na alma e no espírito de quem lê.

Steiner percebeu o que pode ser melhor entendido nas palavras de PerroneMoisés:

Trabalhar o imaginário pela linguagem não é ser capturado pelo imaginário, mas capturar, através do imaginário, verdades do real que não se dão a ver fora de uma ordem simbólica. A fuga do real, ou seu oposto, o realismo, nunca se efetuam totalmente na literatura, pois as duas atitudes têm o real como horizonte e a linguagem como mediação. A linguagem é obstáculo, no caminho do real, mas é também possibilidade de fundá-lo. (...) Pretendendo substituir o real ou, pelo contrário, espelhá-lo, sempre é a ele que a literatura se refere. Tanto a fuga como o mergulho obriga-nos a ver esse real, a questioná-lo e a reinventá-lo (PERRONE-MOISÉS, 1990:109) ${ }^{118}$.

Algumas frases usadas pelos participantes formados por outras pedagogias demonstram isso com clareza, como as respostas dadas pela Raquel, Guilherme, Sarah, Sidney, Val, Bruna, entre outros. Gostaríamos de destacar a frase da Amanda 2, pela sabedoria que está implícita em suas palavras:

"Uma pesquisa interessante, me identifiquei bastante com alguns livros, seria interessante ler para minha irmãzinha que tem apenas 2 anos e pedir para que ela leia quando crescer, porque a cada vez que ela ler esses livros vai tirar uma nova conclusão pela sua experiência de vida".

A resposta para a pergunta "O que acontece quando um jovem adulto tem em

118 [grifos do autor]. 
suas mãos um livro infantil e o utiliza da maneira proposta por Steiner?" é o surgimento de potencialidades latentes, o desabrochar, o aflorar de possibilidades para o conhecer. Subestimamos estes jovens quando enxergamos apenas as deficiências apresentadas por eles em habilidades básicas como a leitura, a escrita e o raciocínio lógico. Parafraseando Perrone-Moisés, o texto é o lugar onde se experimentam "novas formas de ver, sugestivas de novas formas de ser. E que só no encontro dessas novas formas a literatura alcança sua função mais plena e sua ação mais efetiva" (PERRONE-MOISÉS, 1990:89).

Literatura que deve ser entendida não apenas como veiculadora de saberes formais e valores morais, mas principalmente como força impulsora na mediação entre o "coração" e o intelecto para o desenvolvimento e constituição do pensar conceitual. 


\section{6}

\section{CONSIDERAÇÕES FINAIS}

O objetivo principal desta pesquisa era avaliar a validade e atualidade das concepções sobre o querer, o sentir e o pensar de Rudolf Steiner para os estudos literários, por meio da aproximação de suas ideias às reflexões teóricas desenvolvidas no campo da produção estética e da recepção da leitura.

Entre as justificativas apontadas para a escolha de Rudolf Steiner e não de outro pensador, apontamos o período histórico em que ele viveu e produziu suas obras. Período em que se inicia a compartimentação dos saberes nas pesquisas científicas levando à posterior cisão entre Arte e Ciência. Mostramos, por meio dos estudos realizados por Franco Cambi, que um dos temas desenvolvidos na pedagogia alemã desta época era a reflexão em torno da Bildung. A Bildung é tensão "espiritual" do eu, contato profundo com as várias esferas da cultura e da consciência de um crescimento interior para formas de personalidades cada vez mais complexas e harmônicas. É um modelo de formação humana e cultural, que visa, sobretudo, a harmonia do sujeito, a sua liberdade-equilíbrio interior e contrapõe ao cidadão e ao Homo-faber (o homem do "fazer") contemporâneo a utopia da "alma bela" (o homem do "ser"). Além do tema da Bildung, enfatizava-se a função educativa da arte para o desenvolvimento das capacidades cognitivas da criança e do jovem.

Nosso estudo mostrou que há, na atualidade, pensadores como Edgar Morin que defendem a reflexão filosófica centrada no ser humano, presente no pensamento vigente na época e no local em que Steiner produziu suas obras. Não 
há indícios de que Morin tenha lido algum trabalho de Steiner, mas, com certeza, eles beberam nas mesmas fontes. Comprovamos isto no capítulo três com relação ao pensar definido por ambos como uma atividade reflexiva do espírito, que nos dá a "consciência de si". Nas palavras de Morin, "o indivíduo pode dispor da consciência de si, capacidade de se considerar como objeto sem deixar de ser sujeito" (MORIN, 2007:39) ou nas palavras de Steiner, "o pensar, ao dirigir sua atenção à sua própria atividade, converte em objeto o próprio sujeito, isto é, sua essência primordial” (STEINER, 1979:49).

Steiner e Morin defendem a ideia de que é justamente nosso pensamento e nossa consciência que, na objetivação do mundo físico, nos fazem sentir separados deste mesmo mundo ao qual pertencemos. Desta forma, experimentamos nossa dupla natureza: Eu e o mundo (interior e exterior) e somos impulsionados a conhecer e a agir. Como foi dito no capítulo três, o pensar abarca, ao mesmo tempo, o subjetivo e o objetivo e nos comunica a realidade total na união que realiza entre a percepção e o conceito. Não é o conceito abstrato que contém a realidade, mas sim a observação pensante, que não considera por si sós nem o conceito nem a percepção, mas a união de ambos (STEINER, 1979:193-197). De acordo com Morin, "todo conhecimento, toda percepção, ideal ou teórica, é, ao mesmo tempo, uma tradução e uma reconstrução" (MORIN, 2007:96), portanto, uma representação.

Chegamos, assim, à segunda justificativa para a escolha do estudo das concepções de Steiner e não de outro pensador, que é a definição dada por ele à constituição dos atos da vontade. De acordo com Steiner, os atos da vontade são determinados pelo querer, pelo sentir e pelo pensar, e se constituem, individual e coletivamente, por meio das representações e da significação, por meio das 
imagens que representam o mundo e as relações que o homem estabelece com os outros homens e com si mesmo.

Nossa hipótese inicial era que deveria haver semelhanças entre as concepções de Steiner e às reflexões teóricas desenvolvidas no campo da produção estética e da recepção da leitura, já que consideram que não há pensamento sem signos, e que essa concepção de representação ou signo é fundamental para a percepção, para o conhecer e para o agir humano. Além disso, são concepções que priorizam o papel da Arte, da estética, do pensar analógico para a constituição do pensar conceitual.

Dissemos, na introdução desta pesquisa, que esperávamos demover a ideia de construção do conhecimento e enfatizar a constituição do conhecimento que só poderia ser obtido por meio da relação sentimento e razão. Esta relação está diretamente relacionada à forma como as coisas significam e são representadas por cada ser individual. Consideramos, pelo que foi exposto até aqui, ter comprovado essa hipótese.

A terceira justificativa, apresentada por nós para a escolha do estudo das concepções de Rudolf Steiner e não de outro pensador, estava relacionada à importância atribuída por ele às narrativas, consideradas como facilitadoras na integração da parte espiritual-individual da criança à própria corporalidade e facilitadoras da sua adaptação e autonomia futura em sua vida terrestre.

Nosso estudo mostrou, que há vários pontos em comum entre as ideias de Steiner e as de Walter Benjamin, entre eles, a importância da trajetória da alma e dos estágios terrenos de evolução na formação do ser humano integral, a importância das artes em geral e dos contos de fada, mitos, fábulas, lendas etc., 
para a formação da criança. Para eles, essas estórias são portadoras da história "espiritual" da humanidade, são heranças de nossos antepassados que estiveram presente na tradição oral dos povos e são portadoras de importantes conhecimentos sobre a vida e a morte, sobre as relações do homem com os outros homens e sobre as relações do homem com a natureza e com o divino.

A formação proposta por Steiner e por Walter Benjamin visava conservar por toda a vida certas qualidades da juventude, isto é, manter em si, como algo bastante especial, a feliz disposição da idade infantil. Esta característica também é apontada por Mia Couto, que considera importante guardar dentro de si o olhar de criança, conforme mostramos no capítulo três desta tese.

A partir destas considerações, passamos a pensar nos jovens recém formados no Ensino Médio em escolas públicas e estaduais, pois é com esse adulto que lidamos em nossa formação e prática educacional há mais de vinte anos. Passamos a questionar o que poderíamos fazer para resgatar ou revivificar esse olhar de criança, olhar de descoberta, curiosidade, criatividade e imaginação, estados de puro sentir, considerados por Steiner, como embrionários para o conhecer e para o agir. Chegamos, desta forma, as duas perguntas que nortearam esta pesquisa: "Será que isto é possível por meio da literatura?" e "O que acontece quando um jovem adulto tem em suas mãos um livro infantil e o utiliza da maneira proposta por Steiner?".

Para respondê-las elaboramos uma pesquisa de campo que previa duas etapas, conforme exposto no capítulo quatro. O objetivo da primeira etapa era verificar semelhanças e diferenças com relação aos interesses e hábitos de leitura e posicionamento em relação às questões essenciais da vida, como a morte e a 
velhice, entre adultos formados pela pedagogia Waldorf e adultos formados por outras pedagogias. A segunda etapa seria a realização de uma experiência estética de recepção da leitura nos moldes propostos por Steiner.

Os resultados da primeira etapa da pesquisa de campo demostraram um maior desenvolvimento da espiritualidade entre os alunos formados pela pedagogia Waldorf, originalidade em algumas respostas e um posicionamento enquanto ser. Foi possível ouvir suas vozes, enquanto que, em muitas respostas dos alunos formados por outras pedagogias, ouvimos slogans de ditos comuns. Ao mesmo tempo, constatamos o quanto os jovens eram diferentes entre si, independentemente da formação pedagógica que tiveram.

Os resultados obtidos na segunda etapa da pesquisa de campo foram mais significativos. Pudemos comprovar a hipótese de que, por meio das narrativas, utilizadas da maneira proposta por Steiner, é possível mudar comportamentos. As respostas dos alunos formados por outras pedagogias demonstraram isso com clareza. Houve um posicionamento maior por parte dos ex-alunos formados por outras pedagogias após a leitura das obras. Eles se posicionaram enquanto ser e foram originais em suas respostas.

A resposta para a pergunta "O que acontece quando um jovem adulto tem em suas mãos um livro infantil e o utiliza da maneira proposta por Steiner?" é o surgimento de potencialidades latentes, o desabrochar, o aflorar de possibilidades para o conhecer. Subestimamos estes jovens quando enxergamos apenas as deficiências apresentadas por eles em habilidades básicas como a leitura, a escrita e o raciocínio lógico e pioramos muito sua situação quando buscamos minimizar estas deficiências por meio de um ensino puramente racional. É preciso levar em 
conta sentimento e razão e isso pode ser obtido de forma rápida por meio da literatura, conforme proposto por Steiner.

Podemos entender melhor o pensamento de Steiner por meio de uma citação de Leyla Perrone-Moisés:

Na sua gênese e na sua criação, a literatura aponta sempre para o que falta, no mundo e em nós. Ela empreende dizer as coisas como são, faltantes, ou como deveriam ser, completas. Trágica ou epifania, negativa ou positiva, ela está sempre dizendo que o real não satisfaz (...) A literatura empreende suprir a falta por um sistema que funciona em falta, em falso: esse sistema é a linguagem. Os signos verbais são substitutos das coisas, seu uso repousa numa mera convenção de correspondência: tal coisa será representada por tal signo. Assim, dizer as coisas é aceitar perdê-las, distanciá-las e até mesmo anulálas. A linguagem não pode substituir o mundo, nem ao menos representa-lo fielmente. Pode apenas evocá-lo, aludir a ele através de um pacto que implica a perda do real concreto (PERRONEMOISÉS, 1990:104-105).

E ela conclui que o modo literário de buscar a verdade, o real, é o modo simbólico do mito. Em suas palavras: "Muito diverso de um devaneio fantasioso, o mito é um sistema simbólico rigorosamente formalizado" (PEERONE-MOISÉS, 1990:106). A importância da forma é explicada por ela na seguinte citação:

O trabalho da forma se exerce em todos os níveis da obra literária, desde as grandes estruturas, que sustentam a narrativa ou o poema e são suas linhas de forças invisíveis, até o lavor minucioso do estilo, que consiste em colocar as palavras em determinada ordem, pesando como numa balança os sons e os ritmos. A forma buscada pelo escritor é não apenas essa forma sensível na materialidade do 
discurso mas, ao mesmo tempo, a forma do sentido, no arranjo justo das referências, na exploração das conotações. A forma é assim, uma espécie de rede ardilosamente tramada para colher, no real, verdades que não se veem a olho nu, e que, vistas, obrigam a reformular o próprio real (PERRONE-MOISÉS, 1990:106-107).

A intenção do escritor convida o leitor a prosseguir com sua criação, conforme exposto no capítulo cinco desta tese. Portanto, a definição de leitura que perpassa as ideias defendidas nesta tese é a de processo ativo, "de aprendizado de atenção, de sensibilidade e de invenção" (PERRONE-MOISÉS, 1900:109).

Esperamos, através desta pesquisa, ter comprovado a contribuição essencial do estético, da arte, da literatura, para a formação do ser harmônico e integral.

Literatura que deve ser entendida não apenas como veiculadora de saberes formais e valores morais, mas principalmente como força impulsora na mediação entre o "coração" e o intelecto para o desenvolvimento e constituição do pensar conceitual.

Esperamos, também, conforme exposto na introdução desta tese, que esta pesquisa abra novas perspectivas aos professores de escolas da rede pública e estadual, sobre o uso da leitura literária em sala de aula, e aos professores universitários de disciplinas como Interpretação e Produção de Texto e Comunicação e Expressão, além do ensino da Literatura em qualquer nível. Uso que não deve ser entendido como forma de ensinar gramática ou interpretação de texto, mas como interface entre o sentimento e a razão, capaz de proporcionar um estado de encantamento, de puro "sentir", que alimenta a alma e transfigura o pensar, o conhecer, impulsionando à ação. 


\section{REFERÊNCIAS BIBLIOGRÁFICAS}

AGUIAR, Vera Teixeira e BORDINI, M. da Glória. Literatura: a formação do leitor alternativas metodológicas. Porto Alegre, 1988.

ARIÈS, Philippe. História social da criança e da família. Trad. Dora Flaksman. 2ª ${ }^{a}$ ed. Rio de Janeiro: LTC, 1978.

ARROYO, Leonardo. Literatura Infantil Brasileira. São Paulo: Melhoramentos, 1988.

BABBIE, Earl. Métodos de pesquisas de Survey. Trad. Guilherme Cezarino. Belo Horizonte: Ed. UFMG, 1999.

BARKFIELD, Owen. Introducing Rudolf Steiner. Trad. Valdemar W. Setzer, New York, http://www.sab.org.br/antrop/Barfield on Steiner.htm, out-nov, 2005.

BARTHES, Roland. O Prazer do Texto. Trad. J. Guinsburg. Rev. Alice Kyoko Miyashiro. 3a . ed. São Paulo: Perspectiva, 2002.

BENJAMIN, Walter. Reflexões sobre a criança, o brinquedo e a educação. Tradução, apresentação e notas de Marcus Vinicius Mazzari, posfácio de Flávio Di Giorgi. 2a․ ed. São Paulo: Duas Cidades, Ed. 34, 2009.

. Magia e técnica, arte e política: ensaios sobre literatura e história da cultura. Trad. Sergio Paulo Rouanet; prefácio Jeanne Marie Gagnebin. 7a․ ed. São Paulo: Brasiliense, 1994.

. Escritos sobre mito e linguagem. Trad. Susana Kampff Lages e Ernani Chaves. 34 ${ }^{a}$. ed. São Paulo: Duas Cidades, 2011.

. História e narração em Walter Benjamin. Trad. Jeanne Marrie Gagnebin. 2ª. ed. São Paulo: Perspectiva, 2011.

BETTHELHEIM, Bruno. Psicanálise dos contos de Fadas. Rio de Janeiro: Paz e Terra, 1980.

BORGES, Jorge Luiz. O pensamento vivo. São Paulo: Martin Claret, 1987.

BOSI, Alfredo. Reflexões sobre a arte. São Paulo: Ática, 2004.

O ser e o tempo da poesia. São Paulo: Cultrix, 1990.

CAMBI, Franco. História da pedagogia. Trad. Álvaro Lorencini. São Paulo: Fundação Editora da UNESP (FEU), 1999.

CHEVALIER, Jean. Dicionário de Símbolos: mitos, sonhos, costumes, gestos, formas, figuras, cores e números. Jean Chevalier, Alain Gheerbrant, com a colaboração de: André Barbault... [et al.]; Coordenação Carlos Sussekind; Trad. Vera da Costa e Silva... [et. al.]. 26르. ed. Rio de Janeiro: José Olympio, 2012. 
CANDIDO, Antonio. Literatura e sociedade. São Paulo: Cia. Editora Nacional, 1973.

CARVALHO, Bárbara Vasconcelos de. A Literatura Infantil. 3a․ ed. São Paulo: Global,1984.

CIONARESCU, A. Princípios de Literatura Comparada. Tenerife, Universidad de la Laguna, 1964.

COELHO, Nelly Novaes. A Literatura Infantil. 7a. ed. São Paulo: Moderna, 2000. . Literatura infantil: teoria, análise e didática. São Paulo: Moderna, 2000.

Ática, 1991. Panorama histórico da Literatura Infantil e Juvenil. 4a․ ed. São Paulo: . O Conto de Fadas. São Paulo: Ática, 1987.

COUTINHO, E. F. \& CARVALHAL, T. F. (orgs). Literatura Comparada. Textos fundadores. Rio de Janeiro: Rocco, 1994.

CUNHA, Maria Aparecida Antunes. Literatura Infantil: Teoria e Prática. São Paulo: Ática, 1983

CUNHA, Maria Zilda da. Na tessitura dos signos contemporâneos: novos olhares para a Literatura Infantil e Juvenil. São Paulo: Editora Humanitas; Paulinas, 2009.

ELIADE, Mricéa. Aspectos do mito. Lisboa: Edições 70, 1989.

FERRARA, Lucrecia de A. Leitura sem palavras. São Paulo: Ática, 1986.

FIGUEIREDO, Eurídice (Org). Conceitos de literatura e cultura. Juiz de Fora: UFJF, 2005.

FISCHER, Ernest. A necessidade da arte. Rio de Janeiro: Zahar, 1971.

FOUCAULT, Michel. Arqueologia do Saber. Petrópolis: Vozes, 1971.

As palavras e as coisas: uma arqueologia das ciências humanas. Trad. Salma Tannus Muchail. 9ạ. ed. São Paulo: Martins Fontes, 2007

FREIRE, Paulo. Educação e mudança. Trad. Moacir Gadotti et Lílian Lopes Martin. Rio de Janeiro: Paz e Terra, 1979.

GADOTTI, Moacir. História das idéias pedagógicas. São Paulo: Ática, 2003.

GODOI, Christiane Kleinübing; BANDEIRA-DE-MELLO, Rodrigo e SILVA, Anielson Barbosa (org). Pesquisa qualitativa em estudos organizacionais: paradigmas, estratégias e métodos. 2a. ed. São Paulo: Saraiva, 2010.

GÓES, Lúcia Pimentel. Olhar de Descoberta. 2ª . ed. ampl. São Paulo: Ed. Paulinas, 2003. 
GREIMAS, A. J. e COURTÉS, J. Dicionário de Semiótica. São paulo : Cultrix, 1979.

GREGORIN FILHO, José Nicolau. Literatura Infantil: múltiplas linguagens na formação de leitores. São Paulo : Melhoramentos, 2009.

GRUBITS, Sonia e NORIEGA, José A. Vera (org). Método qualitativo: epistemologia, complementaridades e campos de aplicação. São Paulo: Vetor, 2004.

GUIMARÃES, Elisa. A articulação do texto. São Paulo : Ática, 1990.

HEMLEBEN, J. Rudolf Steiner. Trad. brasileira de Heinz Wilda. 2a . ed. São Paulo, Antroposófica, 1989.

HJELMSLEV, Louis. Prolegômenos a uma teoria da linguagem. São Paulo: Editora Perspectiva, 1975.

JESUALDO, J. A Literatura Infantil. São Paulo: Cultrix/USP, 1978.

JOSÉ, Elias. A poesia pede passagem: um guia para levar a poesia às escolas. São Paulo: Paulus, 2003.

JOUVE, Vicent. A Leitura. Trad. Brigitte Hervor. São Paulo: Editora UNESP, 2002.

Por que estudar literatura? Trad. Marcos Bagno e Marcos Marcionilo. São Paulo: Parábola, 2012

LAJOLO, Marisa. Do mundo da leitura para a leitura do mundo. 6ª ed. São Paulo: Ática, 2000.

LAJOLO, Marisa e ZILBERMAN, Regina. Literatura Infantil Brasileira: história e histórias. São Paulo: Ática, 1984.

LETZERICH, Érica. A Evolução dos Objetivos da Sociedade Teosófica. Revista Teosófica, 4ํ․ trimestre de 1996; http://www.teosofia.com.br/artigo108.php,set-out, 2005.

LOPES, Edward. Metáfora: da Retórica a Semiótica. 1a. ed. São Paulo: Atual, 1986.

MACHADO, Álvaro Manuel; PAGEAUX, Daniel-Henri. Da literatura comparada à teoria da literatura. 2ª ${ }^{-}$ed. rer. Aum. Lisboa: Presença, 2001.

MENDES, Maria dos Prazeres Santos. Monteiro Lobato, Clarice Lispector e Lygia Bojunga Nunes: 0 estético em diálogo na literatura infanto-juvenil. Tese (Doutorado em Comunicação e Semiótica) - Programa de Comunicação e Semiótica, PUC, São Paulo, 1994.

MORIN, Edgar. O método 5: a humanidade da humanidade. Trad. Juremir Machado da Silva. 4ª ed. Porto Alegre: Sulina, 2007. 
MUTARELLI, Sandra Regina Kuka. Os Quatro Temperamentos na Antroposofia de Rudolf Steiner. Dissertação (Mestrado) - Programa de História das Ciências, PUC, São Paulo, 2006.

NITRINI, Sandra. Literatura Comparada: história, teoria e crítica. São Paulo: Editora da Universidade de São Paulo, 1997.

NÖTH, Winfriend. Panorama da semiótica: de Platão a Peirce. São Paulo: Annablume, 1995.

PALO, Maria José e OLIVEIRA, Maria Rosa. Literatura Infantil: voz de criança. 4⿳a . ed. São Paulo : Ática, 2006.

PASSERINI, Sueli Pecci. O fio de Ariadne: um caminho para a narração de histórias. 3á. ed. rev. e atual. São Paulo : Antroposófica, 2011.

PEIRCE, Charles Sanders. Semiótica. São Paulo : Perspectiva, 1990.

. Semiótica e filosofia. São Paulo : Cutrix, 1972.

PERRONE-Moisés, Leyla. Flores da escrivaninha: ensaios. São Paulo: Companhia das Letras, 1990.

PERROTTI, Edmir. O texto sedutor na Literatura infantil. São Paulo : Ícone, 1986. . Confinamento cultural, infância e leitura. São Paulo: Summus, 1990.

PIAGET, Jean. A formação do símbolo na criança: imitação, jogo e sonho, imagem e representação. Rio de Janeiro: Zahar, 1978.

1986. . A linguagem e o pensamento na criança. São Paulo: Martins Fontes,

PLAZA, Júlio. Tradução Intersemiótica. São Paulo: Cortez, 1987.

RESENDE, Vânia. Literatura Infantil \& Juvenil - Vivências de leitura e expressão criadora. São Paulo: Saraiva, 1993.

RICHTER, Tobias (Ed.). Objetivos pedagógicos e metas de ensino de uma Escola Waldorf. Trad. bradileira de Rudolf Lanz. São Paulo: Federação das Escolas Waldorf do Brasil, 2002.

ROSEMBERG, Fúlvia. Literatura Infantil e Ideologia. São Paulo: Global, 1984.

SANTAELLA, Lúcia. Matrizes da linguagem e pensamento: sonora visual verbal: aplicações na hipermídia. 3ª. ed. São Paulo: lluminuras: FAPESP, 2005.

SCHOEREDER, G. Blavatsky e a Sociedade Teosófica, http://www.ippb.org.br, 17 de nov. 2005. 
SILVA, Vitor Manuel de Aguiar e. Teoria da Literatura. 8‥ ed. Coimbra: Almedina, 2002.

STEINER, Rudolf. A Arte da Educação I - O estudo geral do homem, uma base para a Pedagogia. Trad. Rudolf Lanz e Jacira Cardoso. 2a. ed. São Paulo, Antroposófica, 1995.

A Arte da Educação II - Metodologia e Didática no Ensino Waldorf. Trad. Rudolf Lanz. 2ª . ed. São Paulo, Antroposófica, 2003.

A Arte da Educação III - Discussões Pedagógicas. Trad. Rudolf Lanz. São Paulo, Antroposófica, 1999.

A Filosofia da Liberdade. Trad. Alcides Grandisoli. São Paulo: Associação Pedagógica Rudolf Steiner, 1979.

A Ciência Oculta. Trad. Rudolf Lanz e Jacira Cardoso. 5‥ ed. São Paulo, Antroposófica, 1998.

A Obra Científica de Goethe. Trad. Rudolf Lanz. São Paulo, Associação Pedagógica Rudolf Steiner, 1980.

. A Educação Prática do Pensamento. Trad. Octavio Inglez de Souza. 3ạ . ed. São Paulo, Antroposófica, 1996.

Das Geheimnis der menschlichen Temperamente. Trad. Brian Kelly; http://www.rsarchive.org/Lectures/FourTemps/19090304p01.html, fev-dez, 2005.

. Educação na Puberdade. Trad. brasileira de Rudolf Lanz. 2ª ed. São Paulo, Antroposófica, 1996. 5a․ ed. Dornach, Rudolf Steiner-Nachlaßverwaltung, 1974.

Dornach: Auflage, 1984.

. Erziehungskunst - Seminarbesprechungen und Lehrplanvorträge. . Mein Lebensgang. 2ª ${ }^{\mathrm{a}}$ ed. Dornach, Fischer Taschenbunch, 1985.

. O Método Cognitivo de Goethe - Linhas Básicas para uma gnosiologia da cosmovisão goethiana. Trad. B. Callegaro e J. Cardoso. 2ª . ed. São Paulo, Ed. Antroposófica, 2004.

Antroposófica, 1996.

O Mistério dos Temperamentos. Trad. Andrea Hahn. 2a . ed. São Paulo, . Os Temperamentos. Trad. Martin Keller. Ribeirão Preto, Convívio, 1990.

. Teosofia. Trad. Daniel Brilhante de Brito e Jacira Cardoso, 7ª̣ ed. São Paulo, Antroposófica, 2004. 
. Verdade e Ciência: prelúdio a uma "Filosofia da Liberdade". Trad. Rudolf Lanz. São Paulo, Antroposófica, 1985.

. Archive, Eletronic Library; http://www.rsarchive.org/, jan-jun, 2014.

VALÉRY, Paul. Discurso sobre a estética. In: LIMA, Luís Costa (Org.). Teoria da literatura em suas fontes. Rio de Janeiro: Martins Fontes, 1975.

VON-FRANZ, M. L. A interpretação dos contos de fada. São Paulo: Paulinas, 1985. . Individuação nos contos de fada. São Paulo:Paulinas, 1985.

WORNICOV, Ruth et al. Criança, leitura, livro. São Paulo: Nobel, 1986.

YUNES, Eliana e PONDÉ, M. da Glória. Leitura e Leituras da Literatura Infantil. São Paulo: FTD, 1988.

ZILBERMAN, Regina (org). A produção cultural para crianças. Porto Alegre: Mercado Aberto, 1982. . A literatura infantil na escola. 7ª̣. ed. São Paulo: Global. 1989.

ZUMTHOR, Paul. Performance, recepção, leitura. Trads. Jerusa Pires Ferreira, Suely Fenerich. São Paulo: EDUC, 2000.

\section{OBRAS DE FICÇÃO}

CHAMLIAN, Regina. Vi uma estrela lá fora. Ilustrações Helena Alexandrino. São Paulo: Paulinas, 2003. (Coleção esconde-esconde).

COLASANTI, Marina. A Moça Tecelã. São Paulo: Global, 2004. (Coleção Marina Colasanti).

COUTO, Mia. O Beijo da Palavrinha. Ilustrações Malangatana. Rio de Janeiro: Língua Geral, 2006. (Coleção Mama África).

O Gato e o Escuro. Ilustrações de Marilda Castanha. São Paulo: Companhia das Letrinhas, 2008.

GRIMM, Jacob \& Wilhelm. A Raposa e o Cavalo. In: BONINI, Íside M. (trad). Contos e Lendas dos Irmãos Grimm. São Paulo: Edigraf, v. II. p.105-107. s/d

HAURÉLIO, Marco (org). O Príncipe Cavalinho. In: Contos e Fábulas do Brasil. llustrações Severino Ramos; classificação e notas Paulo Correia. São Paulo: Nova Alexandria, 2011. p. 56-57. 
VIEIRA, Helena Pinto. Pobre Vovô!. In: BONOW, Iva Waisberg (coord). O Mundo da Criança. Rio de Janeiro: Delta, 1954. v. 1. p. 28.

Vocês Acreditam?. In: BONOW, Iva Waisberg (coord). O Mundo da Criança. Rio de Janeiro: Delta, 1954. v. 1. p. 141. 


\section{ANEXOS}

ANEXO A - Questionário 1: Perfil dos Entrevistados

ANEXO B - Questionário 2: Recepção da Leitura 


\section{QUESTIONÁRIO 1 - PERFIL DOS ENTREVISTADOS}

Nome:

Pseudônimo (apelido a ser usado na pesquisa para preservar seu nome, caso a pesquisa seja publicada na internet):

Data de nascimento: / I

1. Você frequentou o Jardim de Infância?

$$
\operatorname{Sim}(\quad \text { Não( ) }
$$

2. Você cursou o Ensino Médio e o Ensino Fundamental na mesma escola?

$$
\operatorname{Sim}(1) \quad \text { Não( ) }
$$

Se a resposta for NÃO: Você considera que a mudança de escola foi:

$$
\text { Boa ( ) Ruim ( ) Indiferente ( ) }
$$

Quer comentar sua resposta?

3. Das atividades abaixo, assinale aquelas que você praticou até o final do Ensino Médio:

$\begin{array}{llll}\text { Canto ( ) } & \text { Pintura ( ) } & \text { Dança ( ) } & \text { Teatro ( ) } \\ \text { Desenho ( ) } & \text { Ginástica ( ) } & \text { Artesanato ( ) } & \text { Trico ( ) } \\ \text { Flauta ( ) } & \text { Tapeçaria ( ) } & \text { Jardinagem ( ) } & \text { Modelagem ( ) } \\ \text { Marcenaria ( ) } & & & \end{array}$

Quer mencionar alguma atividade que não foi citada?

4. Como você avalia sua vida até o final do Ensino Médio?

Excelente ( ) Boa ( ) Ruim ( ) Indiferente ( )

5. Há alguma atividade realizada na escola da qual você tem saudades?

$$
\operatorname{Sim}(\quad) \quad \text { Não( ) }
$$

Se a resposta foi SIM, qual?

6. Você se considera uma pessoa:

Otimista ( ) Realista ( ) Pessimista ( )


7. Você pratica esportes ou faz ginástica?

Nunca（） Uma vez a períodos irregulares（） Duas a três vezes por mês（） Uma vez por semana ( ) Mais de uma vez por semana ( )

8. Você trabalha?

$\operatorname{Sim}(\quad) \quad$ Não( )

Se a resposta foi SIM, gosta do trabalho que faz?

Sim ( ) Não ( ) Mais ou menos ( ) Na maioria das vezes ( ) Gosto muito ( )

9. Você já escolheu sua profissão?

$\operatorname{Sim}(\quad) \quad$ Não( )

Se a resposta foi SIM, qual?

10. Você está satisfeito com a sua aparência?

Nunca ( ) Raramente ( ) às vezes ( ) quase sempre ( ) Sempre ( )

11. Você se considera uma pessoa interessante?

Nunca ( ) Raramente ( ) às vezes ( ) quase sempre ( ) Sempre ( )

12. Você sabe lidar com suas emoções?

Nunca ( ) Raramente ( ) às vezes ( ) quase sempre ( ) Sempre ( )

13. Você tem o hábito de ler?

Nunca ( ) Raramente ( ) às vezes ( ) quase sempre ( ) Sempre ( )

14. Marque com um " $x$ " os autores já lidos por você:

$\begin{array}{llll}\text { Shakespeare ( ) } & \text { Balzac ( ) } & \text { Dostoievski ( ) } & \text { Flaubert ( ) } \\ \text { Oscar Wilde ( ) } & \text { Goethe ( ) } & \text { Miguel Cervantes ( ) Camões ( ) } \\ \text { Clarice Lispector ( ) } & \text { Dickens ( ) } & \text { Machado de Assis ( ) Kafka ( ) } \\ \text { Monteiro Lobato ( ) } & \text { Proust ( ) } & \text { Fernando Pessoa ( ) }\end{array}$

Quer acrescentar algum autor que não conste da relação e tenha sido lido por você? 
15. Marque com um " $x$ " quais são os seus medos:

\begin{tabular}{|c|c|}
\hline Medo de lugares fechados ( ) & Medo de animais peçonhentos ( \\
\hline Medo de envelhecer ( ) & Medo de morrer ( \\
\hline Medo de sofrer algum acidente ( ) & Medo de dirigir \\
\hline
\end{tabular}

Há algum outro medo que você gostaria de mencionar? Qual?

16. Defina a velhice em uma única frase:

17. Defina a morte em uma única frase:

18. Defina a vida em apenas uma frase: 


\section{QUESTIONÁRIO 2 - RECEPÇÃO DA LEITURA}

Pseudônimo (apelido a ser usado na pesquisa para preservar seu nome, caso a pesquisa seja publicada na internet:

\section{Poema Pobre Vovô! de Helena Pinto Vieira:}

1. Você gostou do poema?

Sim ( ) Não ( ) Mais ou menos ( ) Gostei muito ( )

2. Você gostou da ilustração?

Sim ( ) Não ( ) Mais ou menos ( ) Gostei muito ( )

Quer comentar suas respostas?

\section{Poema Vocês acreditam? de Helena Pinto Vieira:}

3. Você gostou do poema?

Sim ( ) Não ( ) Mais ou menos ( ) Gostei muito ( )

4. Você gostou da ilustração?

Sim ( ) Não ( ) Mais ou menos ( ) Gostei muito ( ) Quer comentar suas respostas?

Livro Vi uma Estrela lá fora de Regina Chamlian:

5. Você gostou do livro?

Sim ( ) Não ( ) Mais ou menos ( ) Gostei muito ( )

6. Você gostou das ilustrações?

Sim ( ) Não ( ) Mais ou menos ( ) Gostei muito ( )

Quer comentar suas respostas? 
Conto A Raposa e o Cavalo da coletânea dos Irmãos Grimm:

7. Você gostou da estória?

Sim ( ) Não ( ) Mais ou menos ( ) Gostei muito ( )

Quer comentar suas respostas?

Conto $O$ Príncipe Cavalinho da obra "Contos e Fábulas do Brasil":

8. Você gostou da estória?

Sim ( ) Não( ) Mais ou menos ( ) Gostei muito ( )

Quer comentar suas respostas?

Livro O Beijo da Palavrinha de Mia Couto:

9. Você gostou do livro?

Sim ( ) Não ( ) Mais ou menos ( ) Gostei muito ( )

10. Você gostou das ilustrações?

Sim ( ) Não ( ) Mais ou menos ( ) Gostei muito ( )

Quer comentar suas respostas?

Livro A Moça Tecelã de Marina Colasanti:

11. Você gostou do livro?

Sim ( ) Não ( ) Mais ou menos ( ) Gostei muito ( )

12. Você gostou das ilustrações?

Sim ( ) Não ( ) Mais ou menos ( ) Gostei muito ( )

Quer comentar suas respostas? 
Nas questões 13, 14, 15, 16 e 17, você deverá marcar com um " $X$ " a(s) estória(s) que representam sua resposta, podendo não assinalar nenhuma, assinalar uma, assinalar mais de uma, ou ainda, assinalar todas.

13. Assinale a(s) estória(s) que fizeram você se sentir parte integrante da estória:

$\begin{array}{ll}\text { O poema Pobre Vovô! ( ) } & \text { O poema Vocês Acreditam? ( ) } \\ \text { O livro Vi uma Estrela lá fora ( ) } & \text { O conto A Raposa e o Cavalo ( ) } \\ \text { O conto O Príncipe Cavalinho ( ) } & \text { O livro O Beijo da Palavrinha ( ) } \\ \text { O livro A Moça Tecelã ( ) } & \end{array}$

14. Assinale a(s) estória(s) que você preferia não ter lido:

$\begin{array}{ll}\text { O poema Pobre Vovô! ( ) } & \text { O poema Vocês Acreditam? ( ) } \\ \text { O livro Vi uma Estrela lá fora ( ) } & \text { O conto A Raposa e o Cavalo ( ) } \\ \text { O conto O Príncipe Cavalinho ( ) } & \text { O livro O Beijo da Palavrinha ( ) } \\ \text { O livro A Moça Tecelã ( ) } & \end{array}$

15. Assinale a(s) estória(s) que você gostaria de ter em sua biblioteca particular:

$\begin{array}{ll}\text { O poema Pobre Vovô! ( ) } & \text { O poema Vocês Acreditam? ( ) } \\ \text { O livro Vi uma Estrela lá fora ( ) } & \text { O conto A Raposa e o Cavalo ( ) } \\ \text { O conto O Príncipe Cavalinho ( ) } & \text { O livro O Beijo da Palavrinha ( ) } \\ \text { O livro A Moça Tecelã ( ) } & \end{array}$

16. Assinale a(s) estória(s) que você indicaria como leitura indispensável as pessoas que você ama:
O poema Pobre Vovô! ( )
O poema Vocês Acreditam? ( )
O livro Vi uma Estrela lá fora ( )
O conto A Raposa e o Cavalo ( )
O conto O Príncipe Cavalinho ( )
O livro O Beijo da Palavrinha ( )
O livro A Moça Tecelã ( )

17. Assinale a(s) estória(s) que fizeram você repensar nas frases que você utilizou para definir a velhice, a morte e a vida no primeiro questionário respondido antes da leitura das obras:
O poema Pobre Vovô! ( )
O poema Vocês Acreditam? ( )
O livro Vi uma Estrela lá fora ( )
O conto A Raposa e o Cavalo ( )
O conto O Príncipe Cavalinho ( )
O livro O Beijo da Palavrinha ( )
O livro A Moça Tecelã ( ) 
18. Dê sua opinião sincera do que representou para você participar desta pesquisa: 